\title{
Xucuru-Kariri: a reconstituição da trajetória de um grupo indígena remanejado e suas habitações em 'novaterra'.
}

\author{
Rosana Soares Bertocco Parisi
}

Tese apresentada à Escola de Engenharia de São Carlos, da Universidade de São

Paulo, como parte dos requisitos para obtenção do título de Doutora em Ciências da Engenharia Ambiental

Orientador: Prof. Associado LD. Dr. Francisco Vecchia

São Carlos

2008 
AUTORIZO A REPAOOUCCAO E DMULGACANO TOTAL OU PARCIAL DESTE TRABALHO, POR OUALOUER MEIO CONVENCIONAL OU EIETRONICO, PARA FINS DE ESTUDO E PESOUISA, DESDE QUE CITADA A FONTE.

Flcha cotciogrifica preparada pela Secto de Tratamento da Informaglo do Servico de Bblioteca - ESCRUSP

$\mathrm{P} 234 \mathrm{x}$

Parisi, Rosana Soares Bertocco

Xucuru-Kariri : a reconstituiçäo da trajetória de un grupo indígena renanejado e suas habitaçőes en

"novaterra" / Rosana Soares Bertocco Parisi ; orientador

Francisco Vecchia. -- Säo Carlos, 2008

Tese (Doutorado-Programa de Pós-Graduacäo e Área de Concentração en Ciências da Engenharia Ambiental)

Escola de Engenharia de são Carlos da Universidade de säo Paulo, 2008.

1. Indios - habitação. 2. Terra-crua-

3. Condicionamento térmico. 4. Sustentabilidade.

I. Titulo. 


\section{Candidata: Arquiteta ROSANA SOARES BERTOCCO PARISI}

Tese defendida e julgada em 26/09/2008 perante a Comissão Julgadora:

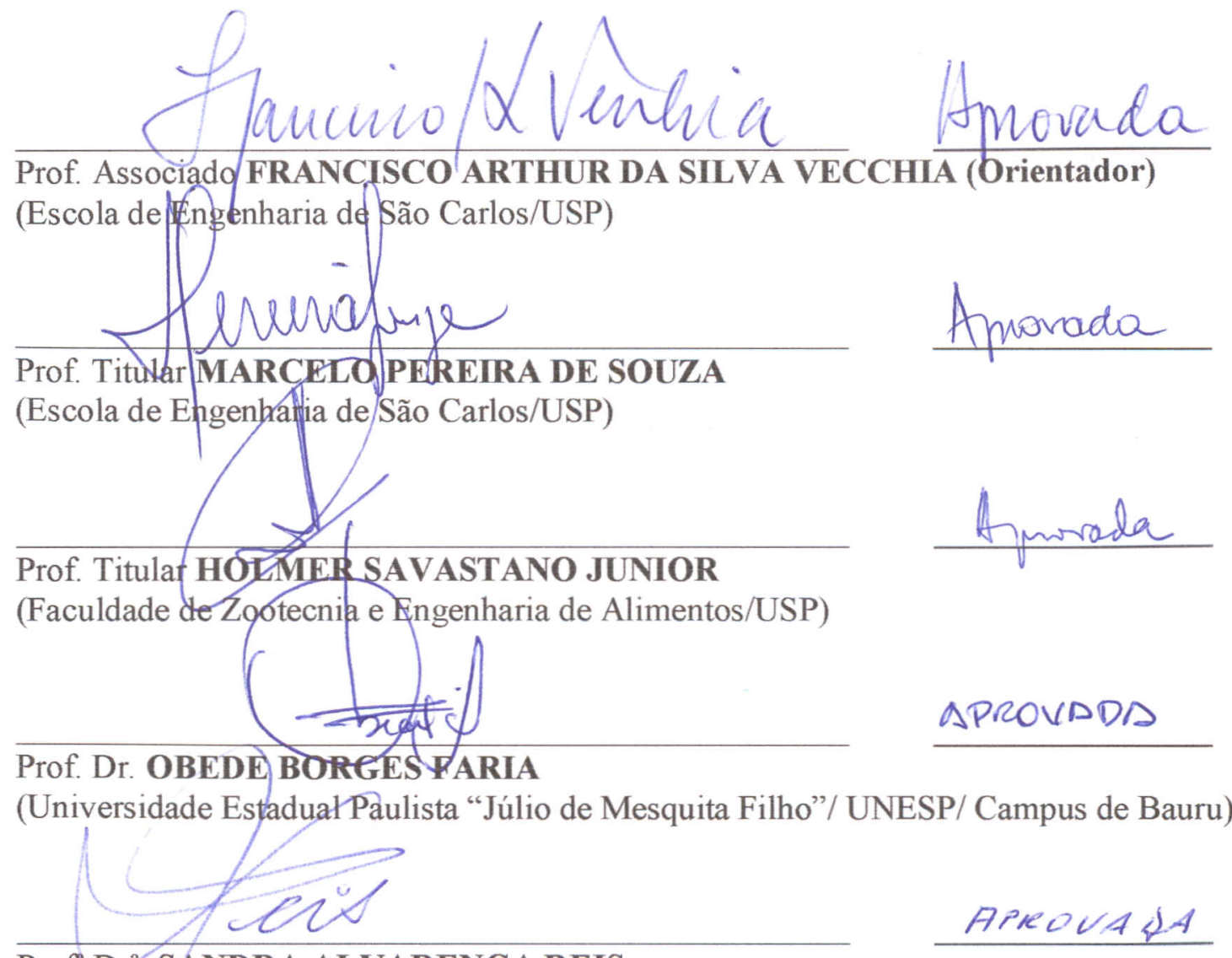

Prof. Dr. ${ }^{2}$. SANDRA ALVARENGA REIS

(Pontifícia Universidade Católica/PUC)

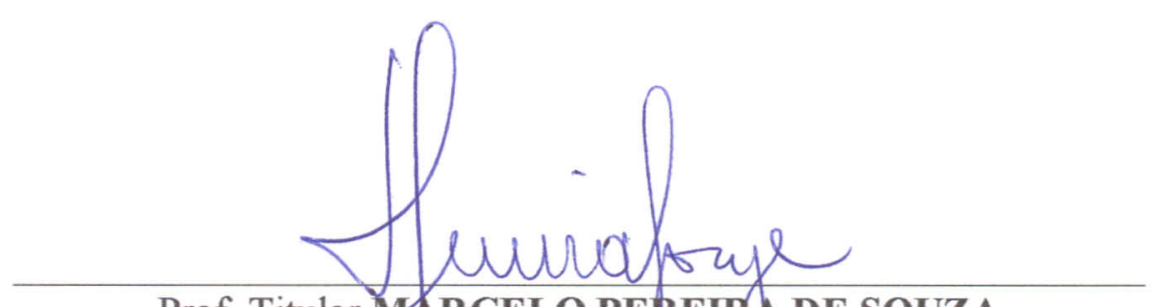

Prof. Titular MARCELO PEREIRA DE SOUZA

Coordenador do Programa de Pós-Graduação em

Ciências da Engenharia Ambiental

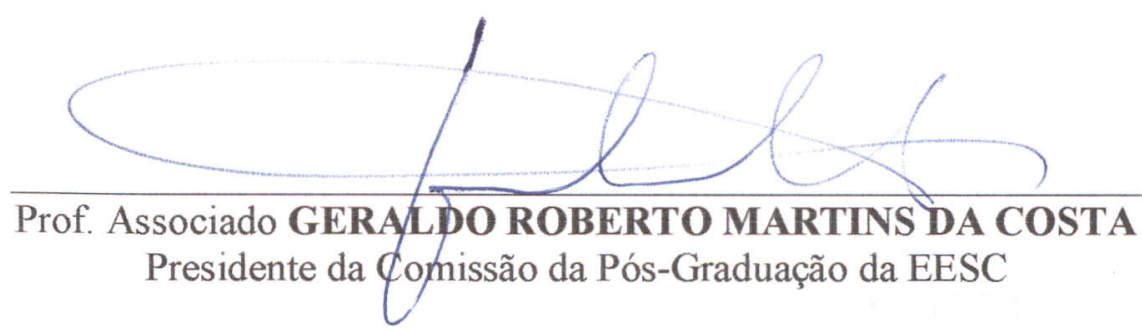




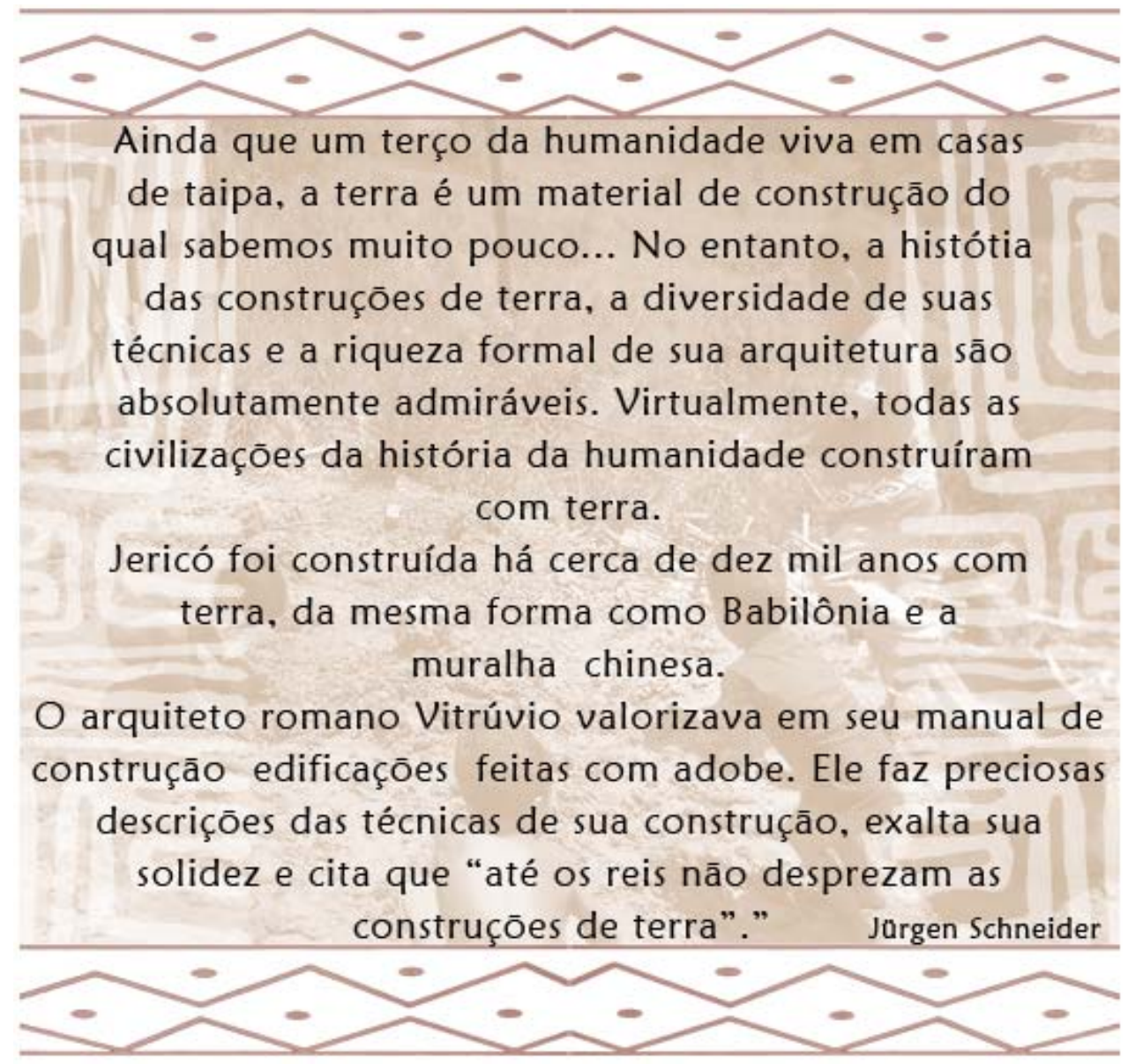

Dedicatória

Dedico este trabalho a meu marido Paulo Júnior, aos nossos filhos e tesouros Paulo Eduardo e Luís Fernando e, agora, à pequenina Carolina. A minha batalha interminável, o meu prazer, a minha coragem e energia se materializam através do AMOR desmedido e despreendido de vocês. Nada disso seria possível sem seu porto seguro que me coloca nesta TERRA. 


\section{Agradecimentos}

"O mundo é melhor porque VOCÊS existem." (Saint Exupéry)

Desde o início desta jornada, conheci e convivi intensamente com pessoas e instituições que se tornaram, cada qual a seu modo, fundamentais para a consolidação deste trabalho. Agradeço a todas e, em especial:

Ao Eterno Pai, por me conceder saúde, equilíbrio e energia para desfrutar com intensidade as alegrias e as dificuldades em cada momento desta pesquisa.

À PUC-Minas, pela concessão do Auxílio de Carga Horária através do Programa Permanente de Capacitação Docente.

Aos amigos de jornada acadêmica do campus de Poços de Caldas, representados pela Pró-Reitora Adjunta, Profa. Dra. Maria José Viana Marinho de Mattos e pelos professores do Curso de Arquitetura e Urbanismo onde exerço a docência, sob a coordenação do Prof. Arq. MSc. Carlos Eduardo Pozzer, muito obrigada. Obrigada pelas palavras, incentivos, demonstrações de carinho e respeito, esforços desmedidos para cobrirem algumas de minhas necessárias ausências. Se hoje consigo finalizar esta pesquisa, saibam que a confiança e a torcida de vocês foram importantes. 
Ao FIP-Fundo de Incentivo à Pesquisa da PUC-Minas, que patrocinou a pesquisa "Medindo e Reciclando, uma experiência sustentável" no período de 01 de agosto de 2005 à 01 de junho de 2006 cujos recursos enriqueceram e implementaram a parte instrumental do Doutorado.

Ao Prof. Éricles Pimenta Freire, do Curso de Engenharia da PUC-Minas, campus de Poços de Caldas, responsável pelo Laboratório de Solos dessa Universidade, pela presteza, pelo profissionalismo e pela contribuição no período em que necessitei da análise do solo da Fazenda Boa Vista de Caldas, atual Reserva Indígena Xucuru-Kariri.

Aos amigos e colegas de jornada diária Adriane de Almeida Matthes, Antônio Carlos Rdrigues Lorette, Esther Aparecida Cervini e Francisco José Cardoso pelo carinho, pelas orações, pela paciência e pelo incentivo constante.

Ao Prof.LD Dr. Francisco Artur da Silva Vecchia: no fundo de seus olhos encontrei a sabedoria, o carinho e a seriedade necessários para, de fato, desenvolver uma pesquisa. Sua armadura e dureza aparentes e as tantas 'chamadas' foram elementos necessários para que hoje eu possa me sentir uma pesquisadora de fato. Não há palavras que abarquem a gratidão, o reconhecimento e a admiração que sinto.

À Profa. Dra. Glacir Teresinha Fricke, estrela-guia, incansável batalhadora e incentivadora, colega, irmã que não tive e grande amiga, dizer obrigada é muito pouco. Mais que isso, é bom saber que partilha os mesmos propósitos e ideais que tenho para 
a concepção de habitações que melhorem e dignifiquem a vida dos cidadãos, indistintamente.

Ao amigo, 'irmão' e colega de Doutorado Prof. Arq. Gabriel Castañeda Nolasco da UNACH, Chiapas, México, por tantas experiências compartilhadas durante o processo de nosso Doutoramento. Certamente a sua paixão pela docência e pesquisa determinou novas visões e a conseqüente maturação de meu trabalho.

Ao Seu Landi, tão amigo, meio pai, tão atento e extremamente profissional, por sua preciosa colaboração através da maquete que acompanhará a apresentação desta pesquisa, que, mais que minhas palavras, seguramente facilitará a compreensão do processo construtivo nela adotado. Muito obrigada por todas as vezes em que ouviu, pacientemente, minhas lamúrias...

Aos alunos e ex-alunos do Curso de Arquitetura da PUC-Minas, campus de Poços de Caldas, que, cada um a sua maneira, puderam dar alguma forma de colaboração e fundamentalmente sua alegria, disponibilidade e vontade de aprender: os bolsitas Arlei Davoli Júnior, Letícia Loiola, Eduardo Manfrin e Cinara Calixto e os voluntários Mayra Carvalho, Thales Cury, Danilo Barrero, Jonathan Amarante, Daniela Guardabaxo, Lívia Barbosa, Maycon Douglas, Ester Caixeta e, mais recentemente, Eliana Marcon Tramontina, Vanderson Chagas, Bruno Lamarão, Tiago Fernandes, Alejandra Melgar, Paulinho Diogo, Marcus Vinícius e a todos os outros que acabo contagiando com minha paixão pela terra! 
Ao Thiago Luz, também 'luz' em meu caminho, aluno exemplar e agora arquiteto, pela preciosa colaboração, seja nos desenhos e detalhes de última hora, seja na diagramação, no empenho, determinação e seriedade de seu trabalho. Continue com essa garra e competência e tenha muito mais sucesso!

Ao amigo e colega de Doutorado Ricardo Victor Rodrigues Barbosa, da Universidade Federal de Alagoas, e a toda sua família, pelo apoio desmedido durante minha permanência em Maceió e Palmeira dos Índios, pelo apoio durante as análises térmicas, por tanta colaboração e paciência durante momentos de alegria e de angústias... Saiba que o seu entusiasmo, sua disponibilidade, seu equilíbrio e calma em fazer com que eu entendesse aspectos a mim, aparentemente, árduos, foram preciosos para o desenvolvimento metodológico da pesquisa.

Aos professores Antropólogos MSc. Siloé Soares de Amorim e Dra. Sílvia Aguiar Carneiro Martins da Universidade Federal de Alagoas, amigos distantes e ainda assim presentes através da disponibilidade, das informações e dos especiais saberes que me fizeram compreender melhor os índios Xucuru-Kariri e o seu percurso de Alagoas a Minas Gerais.

Aos amigos Adilson Lima e Dr. Jorge Vieira, de Palmeira dos Índios-AL, e aos demais 'palmeirenses' que colaboraram de diversas formas a fim de que eu chegasse à Fazenda Canto, de onde partiram os Xucuru-Kariri há mais de quinze anos em busca de uma 'terra prometida', que talvez seja, finalmente, a Reserva de Caldas. 
Ao apoio e incentivo do PROTERRA - Programa Ibero Americano de Construccion com Tierra, através da então 'jefecita' MSc.Célia Martins Neves e da valiosa contribuição do amigo Dr. Obede Borges de Faria, da Faculdade de Engenharia Civil da UNESP-Bauru, do Dr. Marco Antônio Penido de Rezende, da Escola de Arquitetura da UFMG, da colega, amiga e incentivadora MSc. Ana Cristina Villaça, da Universidade Federal Rural do Rio de Janeiro, dos mineiríssimos Raymundo Rodrigues e Marcos 'Reco' Borges, das colegas, professoras e incentivadoras portuguesas Mariana Correia e Maria Aleixo, da encantadora Lucia Gárzon, da Colômbia, com seu ânimo infinito e dos demais membros que colaboraram com suas experiências, suas práticas, suas pesquisas e conhecimentos que me fazem, dia-a-dia, ainda mais apaixonada pela terra.

À Dra. Wilza Gomes Reis Lopes, professora da Universidade Federal da Paraíba, pelo contato virtual profícuo, pelos materiais fornecidos com tamanha generosidade e por seu importante apoio e incentivo à distância concedidos.

Aos amigos e colegas de disciplinas no CRHEA-USP Antônio Eduardo Cabral, Adeildo Cabral Silva, Mariano Franca e Mara Pagliuso Jorge com quem foram possíveis agradáveis momentos em diversos períodos do Doutoramento. Que nossos laços não se limitem às nossas pesquisas acadêmicas.

À 'nação' Xucuru-Kariri de Caldas: Cacique Uarkanã de Aruanã ou Cacique José Sátiro ou simplesmente Seu Zezinho e todos os índios que durante este processo se tornaram minha numerosa família: sua alegria, espontaneidade, simplicidade, humildade e amizade são preciosidades que descobri a partir de 2002... com quem desejo aprender 
e conviver para sempre. Ainda que eu esteja ausente em inúmeros momentos de suas jornadas, agora, mineiras, vocês me acompanharão por toda a vida.

Aos funcionários e pesquisadores do CRHEA, à secretária Claudete, ao solícito Nelson Tessarin, ao Seu Maurício, misto de zelador e 'guardião' do campus do Broa por tanta disponibilidade e generosidade.

À EPAMIG - Caldas, representada pelos simpáticos Achson e Isa, à INFRAERO, representada pela Meteorologista Márcia e ao SIMGE, representado pelo Meteorologista Dayan, pela presteza com que me atenderam quando necessitei de informações acerca do clima e temperatura dos municípios mineiros de Poços de Caldas, Machado e Caldas.

Ao competente e talentoso Davi Kodi Sato, que resgatou no Distrito de Guarda dos Ferreiros, em São Gotardo-MG, as histórias de membros do grupo Xucuru remanejado que ainda hoje lá residem. Através de seu olhar atento, o fotógrafo documentou em belas imagens os locais que seguramente fazem e farão parte da memória indígena.

Ao amigo José Eduardo Baptistella, parceiro e colaborador em tantos trabalhos, pela constante presença, pela paciência, pela simplicidade e pela capacidade.

À Ofélia Prado Soares com seus profícuos 92 anos, minha avó materna e madrinha, com quem aprendi o verdadeiro significado de lucidez, de equilíbrio, de serenidade, de 
humildade, de determinação e de sabedoria, por suas lições que continuam orientando meu dia-a-dia.

A meus pais, Marilena e Gildo, que me chamam de guerreira: se hoje posso me considerar uma guerreira é por que vocês foram, além de pais, meus sábios e persistentes Mestres... amo vocês e, com carinho, digo-lhes, mil vezes, obrigada!

Por último, a meu irmão Marcelo, aos demais familiares, aos amigos - próximos ou distantes e a todos aqueles "anônimos" que colaboraram com palavras de incentivo e de carinho. Agradeço àqueles que rezaram e torceram por mim, que certamente são "anjos da guarda", tão importantes quanto aqueles a quem nominalmente agradeci anteriormente!

"Obrigada por tudo e para sempre". (C.Lubich) 


\section{SUMÁRIO}

página

LISTA DE SIGLAS e UNIDADES

i

LISTA DE FIGURAS __ li

RESUMO

ABSTRACT

CAPİTULO 1

INTRODUÇÃO, JUSTIFICATIVAS E OBJETIVOS 1

1.1. Introdução

1

1.2. Justificativas

9

1.3. Objetivos

1.3.1. Objetivos específicos

CAPÍTULO 2.

Bases Científicas

20

2.1.Povos Indígenas no Brasil - breve histórico

2.2. O contexto da habitação indígena

2.3. Os índios do Nordeste 
2.4. Os Xucuru-Kariri em Alagoas

2.5. O percurso do grupo remanejado ___ 38

2.6. O município de Caldas, local da fixação dos Xucuru-Kariri ___ 45

2.7. A Reserva Indígena de Caldas em 2001___ 47

2.8. O Bajareque, o Bahareque e a Quincha: referências para a adaptação de $\quad 48$ uma tecnologia construtiva

2.9. Experiências alternativas para construções em terra no Brasil

2.10. A proposta das habitações em 'novaterra'

2.11. A escolha da terra como material de construção

2.11.1. Aspectos históricos

2.12. As técnicas de construção com terra introduzidas no Brasil desde o período colonial.

2.12.1. Os adobes

2.12.1.1. A técnica construtiva com a utilização de adobes

2.12.2. A taipa

2.12.2.1. Definição e a técnica construtiva da taipa de pilão

2.12.2.2. A taipa de mão ou pau-a-pique: antecedente da 'novaterra'

2.12.2.2.1. A estrutura e materiais empregados na taipa de mão no Brasil 
CAPÍTULO 3.

Bases metodológicas

3.1. A área de estudo: a Fazenda Boa Vista, atual Reserva Indígena

3.2. Os solos encontrados junto à Reserva Xucuru-Kariri

3.3. As etapas de elaboração do projeto e construção

3.4.Os arranjos construtivos propostos e os arranjos finais da construção

108

3.5. Construindo uma nova experiência no canteiro de obra

3.6. A racionalização do detalhamento do projeto da estrutura de madeira com objetivo de realizar um processo construtivo racional e sustentável

3.7. Avaliações térmicas: significados e importância

3.8. Avaliação térmica de uma das habitações em 'novaterra' e da habitação 'testemunho': análise e interpretação dos resultados junto à Reserva XucuruKariri

3.8.1. Os equipamentos de monitoramento instalado junto à Reserva Indígena

3.8.2. Registros de dados de temperatura

3.8.2.1. O primeiro período de avaliações

3.8.2.2. Interpretação dos resultados relativos ao primeiro período analisado_

3.8.2.1. Temperatura do ar interior

3.8.2.2. Temperatura superficial da parede

3.8.2.2.3. Resultados do primeiro período de avaliações térmicas

3.8.3. O segundo período de avaliações 
3.8.3.1. Interpretação dos resultados relativos ao segundo período analisado

3.8.3.1.1. Temperatura do ar interior

3.8.3.1.2. Temperatura superficial da parede

3.8.3.1.3. Resultados do segundo período de avaliações térmicas 139

3.9. Resultados

CAPÍtULO 4.

141

Discussão

4.1. Contribuições e possibilidades do melhoramento de outros tipos de habitações com a utilização da 'novaterra'

4. 2. A questão das tipologias destinadas às habitações de diversos povos indígenas

CAPÍTULO 5.

Conclusões e Considerações Finais

CAPÍTULO $6 . \quad 165$

Bibliografia

6.1. Bibliografia citada

6.2. Bibliografia consultada 


\section{Lista de Siglas, Unidades e Figuras}

\section{SIGLAS}

ABCTerra - Associação Brasileira dos Construtores e Pesquisadores da Terra ANAI - Associação Nacional de Ação Indigenista

ANTAC- Associação Nacional de Tecnologia do Ambiente Construído

BTC - Bloco de Terra Comprimida ou Bloco de Terra Compactada

FUNAI - Fundação Nacional do Índio

FUNASA - Fundação Nacional de Saúde

CEPED - Centro de Pesquisas e desenvolvimento

CIMI - Conselho Indigenista Missionário

CMMAD - Comissão Mundial sobre o Meio Ambiente e Desenvolvimento

COHAPAR - Companhia de Habitação do Paraná

COCOES - Comité de Construcción de Escuelas del México

COHRE - Legal Resources for Housing Rights

CPTEC - Centro de Previsão de Tempo e Estudos Climáticos

CRATerre - Centre Internacional de la Construcion en Terre

CRHEA - Centro de Recursos Hídricos e Ecologia Aplicada

CYTED - Programa de Ciencia y Tecnologia para el Desarrollo

EESC - Escola de Engenharia de São Carlos

EMATER- Empresa de Assistência Técnica e Extensão Rural do Estado de Minas Gerais

EPAMIG - Empresa de Pesquisa Agropecuária de Minas Gerais

EESC - Escola de Engenharia de São Carlos

HABYTED/CYTED. Subprograma XIV. Tecnologías de Vivienda de Interés Social

ICCOROM - Internacional Centre for the Conservation and Restauration of Cultural Property

IGAM - Instituto Mineiro de Gestão dos Recursos Ambientais e Meteorológicos INFRAERO - Empresa Brasileira de Infra-Estrutura Aeroportuária INPE - Instituto Nacional de Pesquisas Espaciais ININVI - Instituto Nacional de Investigação e Normalização da Vivenda ISA - Instituto Socioambiental 
OMS - Organização Mundial de Saúde

PROTERRA - Programa Ibero- Americano de Construção com Terra

PUC-Minas - Pontifícia Universidade Católica do Estado de Minas Gerais

PUCP- Pontifícia Universidade Católica do Peru

PPCD - Programa Permanente de Capacitação Docente

SIMGE - Sistema de Meteorologia e Recursos Hídricos de Minas Gerais

TerraBrasil Rede - Rede Brasileira de Arquitetura e Construção com Terra

UNACH Universitad Autónoma de Chiapas, Mexico

USP Universidade de São Paulo

\section{UNIDADES de medida utilizadas}

ha hectare ( unidade de medida de área, onde 1 ha= 10.000 m2)

Km quilômetro

Km2 quilômetros quadrados

m2 metro quadrado

$\mathrm{ml}$ metro linear

\section{LISTA DE FIGURAS}

Fig. $\quad$ O interior de duas habitações utilizadas pelos índios Xucuru-Kariri em 4

1.01 Caldas e seus aparelhos eletro-eletrônicos. Fotos: Parisi, R.S.B. dezembro/2004

Fig. Índios do Nordeste e índios Xucuru. Fotos 2002-2004: Hahum, R.; 20

2.01 Amorim,S. e Parisi, R.S.B.

Fig. Reprodução da llustração de Hans Standen mostrando paliçadas em 25

2.02 torno do agrupamento indígena Tupinambá de 1557. Disponível em: http://www.athena.pub.com. Acesso em: 08 mai.2008.

Fig. Habitações Indígenas simplificadas. Disponível em <http/l: 25

2.02a. www.uh.edu/engines/debry2.gif>. Acesso em: 04.fev.2008.

Fig. Habitação Indígena elíptica dos índios Yawalapiti.

2.03 Fonte: MONTEZUMA, R. (Org.) Brasil 500 anos, Recife: 2002, Editora da UFPE.

Fig. Variação do modelo anterior nas malocas dos índios Marúbo. Fonte: 28 MELATTI, J.C. in Índios do Brasil. Brasília: Coordenada, 1977. 
Fig.

2.05 DERANJI (2002:042). Em: MONTEZUMA, R. (Org.)(2002): Brasil 500 a e b. anos, Recife: Editora da UFPE.

Fig. Outra variação de habitação indígena pode ser observada na casa dos

2.06 Poyanáwa do Acre, conforme MELATTI, J.C.(1977) em Índios do Brasil. Brasília: Coordenada.

Fig. Diversas etnias do Nordeste Brasileiro (Potiguaras, Kariri, Xuxuru-Kariri,

2.07 configurando a categoria de índios 'misturados'.Disponível em $<$ www.indiosonline.org.br/.../users/alex/2.jpg> acesso em : 03jun.2008; disponível em: <http://jornalforquilha.blogspot.com/2007/11/ndiosinvadem-sede-da-funai-em-paulo.html> acesso em: 03jun.2008; disponível em: <www.vermelho.org.br/images/indio.jpg> acesso em: acesso em: 03jun.2008; Parisi, R.S.B. (2006); Rios, M. disponível em: < www.flickr.com> acesso em: acesso em: 03jun.2008.

Fig. Mapa do Estado de Alagoas destacando em vermelho a localização de

2.08 Palmeira dos Índios, no agreste alagoano e uma imagem desta cidade, com a localização da capital Maceió à beira-mar.

Fonte: <www.picasaweb.google.com/.../VFZ7COYdAWOcN7IwBFAa6g $>$ disponível em 12.dez.05

Fig. Imagens da organização da Área Indígena da Fazenda Canto em 2006.

2.09 Fontes: Parisi,R.S.B. e ANTUNES, C. Wakona-Kariri-Xukuru,(1973).

Fig. Imagens de Ibotirama. Disponível em: < 39

2.10.1 www.vibeflog.com/nets2/p/9445035> acesso em 02.jul.2008

Fig. Momentos da ocupação Xucuru-Kariri na Fazenda Pedrosa, Quixaba, 40

2.10.2 Nova Glória-BA.Fotos cedidas pelo Cacique Zezinho em junho de 2008. Imagens cedidas pelo Cacique José Sátiro em maio de 2008.

Fig. Imagens de São Gotardo-MG com destaque para o distrito de Guarda 2.11 dos Ferreiros. Na última imagem o Cacique Zezinho em sua casa de alvenaria no Distrito da Guarda. Imagens cedidas pelo Cacique José Sátiro em maio de 2008.

Fig. Imagens do Distrito de Guarda dos Ferreiros., com destaque para a 42 2.11a casa onde residem os Xucuru-Kariri remanescentes.

Imagens realizadas pelo fotógrafo Davi Kodi Sato, em 20.jun.2008.

Fig. Imagens do Distrito de Guarda dos Ferreiros, com destaque para as

2.11b duas casas onde os Xucuru-Kariri moraram. Imagens realizadas pelo fotógrafo Davi Kodi Sato, em 20.jun.2008.

Fig. Mapa do percurso dos índios Xucuru Kariri. Produção de LUZ,T.(2008) a 44 
2.12 partir de dados disponíveis em: <www. earth.google.com>. Acesso em: 27. jun.2008

Fig. Imagens de Caldas, município onde os Xucuru-Kariri estão assentados desde

$2001 . \quad$ Disponível em: http://www.flickr.com/photos/11736651@N00/2683820214/_. acesso em: 12.jun.2008 e disponível em: < http://www.epamigcaldas.gov.br/Abertura/abertura.html $>$ acesso em 15.jun.2008.

Fig. Mapa com a localização da Reserva Xucuru-Kariri. Produção de 46

2.14 LUZ,T.(2008), adaptado a partir de: <www. earth.google.com>. Acesso em: 27 jun.2008.

Fig. A Reserva Indígena Xucuru-Kariri e a Fazenda Canto.

2.15 Fotografias: Parisi,R.S.B., (2004) e (2005).

Fig. Localização da Reserva Indígena Xucuru-Kariri no município de Caldas 2.16 e no Estado de Minas Gerais. Bases cartográficas disponíveis em < http://www.brasildemochila.com/imagens/mg.jpg >. Acesso em: 16.fev.2006.Fotografias: Parisi,R.S.B.(2003) e Tratamento: Davoli Jr., A. (2006).

Fig. A Fazenda Boa Vista, atual Reserva Xucuru-Kariri em Caldas-MG 48

2.17 Implantação e localização das habitações desde 2001 até 2008. Tratamento da imagem LUZ,T.(2008).

Fig. As nove edificações existentes na Fazenda Boa Vista, em Caldas-MG, 49

2.18 quando os índios Xucuru em maio de 2001 afixaram-se na propriedade. Fotos de Parisi, R.S.B. mar-ago. 2002.

Fig. As duas habitações construídas em taipa-de-mão ou pau-a-pique pelos

2.19 Xucuru-Kariri em Caldas no ano de 2002. Fotos de Parisi,R.S.B. 2002.

Fig. Habitações Xucuru-Kariri encontradas na Fazenda Canto, em Palmeira 51

2.20. dos Índios em 2006.Fotos de Barbosa, R,V. e Parisi,R.S.B. Jul. 2006

Fig. Imagens de habitações em terra Xucuru-Kariri extraídas da obra de

2.21 ANTUNES (1973): Wakona-Kariri-Xukuru. Maceió: Universidade Federal de Alagoas.

Fig. Imagens de transformações habitações Xucuru-Kariri em Caldas. Fotos

2.22 de: Parisi,R.S.B. mai.2004 e ago.2005.

Fig. Habitação construída em tecnologia convencional com recursos da

2.23 comunidade religiosa de São Pedro de Caldas, denominada como 'habitação testemunho'. Fotos: Parisi, R.S.B., mar. 2003.

Fig. $\quad$ Casa de bahareque na Venezuela. Disponível em: < www.panoramio.com/photo/8037247> Acesso em: 02abr.2008 e casa 
2.24 de bajareque. Foto: Parisi,R.S.B. em set.2005.

Fig. Ficha sobre o Bajareque Mejorado escaneada da publicação do CYTED

2.25 denominada Un techo para vivir.pp.193-197.

Fig. $\quad$ Ficha da Quincha Pré-Fabricada escaneada da publicação do CYTED

2.26 denominada Un techo para vivir". pp.181-187.

Fig. A taipa moderna: croquis da proposta para a Vila Operária de 64 2.27 Monlevade, projeto de 1934 do arquiteto Lúcio Costa.Disponível em:< www.vitruvius.com.br/.../arq000/esp147.asp>. Acesso em 05.jul.2008 e <www.arcoweb.com.br/debate/debate82.asp $>$. Acesso em 05.jul.2008.

Fig. Imagens de detalhes da Taipa proposta por Acácio Gil Borsói. Em

2.28 Projetos \& Fachadas. Edição Especial de Casa \& Jardim no 327/jan.1982.Rio de Janeiro: Efecê Editora. p.34-41.

Fig. Índios Xucuru manuseando a palha e a palha triturada. Fotos: Parisi, 68

2.29 R.S.B. out.2004 e mai.2004.

Fig. $\quad$ Fotos das Oficinas. Fotos:Castañeda,G. e Parisi,R.S.B . set. e out.2004

2.30

Fig. Imagem das maquetes virtuais da casa de três dormitórios elaboradas

2.31 por Davoli Jr.,A. jun.2004.

Fig. Davoli Jr, A. (2006). Painel de 'novaterra'.

2.32

Fig. Davoli Jr, A. (2004). Esquema da subcobertura proposta e sua produção

2.33 fotos: Parisi,R.S.B. out.2005 e mai.2006.

Fig. Muralha da China. Disponível em: < 74

2.34 www.pime.org.br/mundoemissao/historiasegredos.htm. Acesso em 23nov.2007. e Centro Histórico de Shibam. Disponível em: $<$ www.skyscrapercity.com/showthread.php?t=389138> acesso em: 27nov.2007.

Fig. Mesquita de Djenne. Disponível em:< http://static- 75

2.35 p3.fotolia.com/jpg/00/00/35/92/400 F 359210 D310Q5YwgHfG9F8s75 gHA3Vt0639GR.jpg >.acesso em:01.jun.2006. e o sítio arqueológico de Chan Chan. Disponível em: < http://www.orquidea.net/the north/Chan Chan La Libertad.jpg

>.acesso em: 04.jun.2006.

Fig. Imagens das ruínas Tihuanaco na Bolívia. Disponíveis em: < 76

2.35a http://skidbr.blogspot.com/2007 0311 archive.html> acesso em:03.09.2005.

Fig. Diagrama das tecnologias de terra. Cf. FERNANDES,C. adaptado dp 77

2.36a CRATerre., 2006. Imagem do Diagrama estabelecido pelo grupo CRATerre das diferentes famílias de sistemas de construção antigos e modernos que utilizam a terra como matéria prima adaptado de 
Fernandes,M.(2006).Técnicas de construção com terra p.21 em Terra: forma de construir.Arquitectura-Antropologia- Arqueologia. Porto: Universidade do Porto. p.21. cf. originais cedidos por HOUBEN,H; GUILLAUD,H.(1989). Traité de Construction em Terre. Marseille:Editions Parenthèses.p.15.

Fig, A Casa Bandeirista do Sítio do Pe. Inácio. Disponível em:<

2.36 http://www.vitruvius.com.br/entrevista/katinsky/katinsky03.jpg >.acesso em: 15.04 .2008 e a Matriz de Pirenópolis-GO. >.acesso em: http://arboretto.blogspot.com/2007/10/igreja-matriz-de-pirenpolis.html . Disponível em: 12.mai.2004 e Matriz de Nossa Senhora do Ó http://cienciahoje.uol.com.br/images/chdia/n604a.jpg

Fig. A sede da Faz. Pau D'Alho conforme WINTER, M.C.(2007). Os usos do

2.37 patrimônio em três fazendas cafeeiras paulistas do século XIX. Disponível em: < http://www.klepsidra.net/klepsidra21/fazendas4.htm. Acesso em: $27 f e v .2007$ e a Faz. Milhã em Piracicaba-SP. Disponível em:

$<$ http://www.aprovincia.com/padrao.aspx?texto.aspx?idContent=82551\&i dContentSection=709> acesso em 27fev.2007.

Fig. A Casa Ecológica de Sverre Fehn e as duas obras do arquiteto chileno

2.38 Marcelo Cortez (Casa Penaloen e Granja Aventura), ambas de 2006: dois interessantes e significativos exemplos da arquitetura de terra na contemporaneidade.

Fontes: Revista Projeto $n^{\circ} 168-p$. e fotos do arquivo pessoal de Marcelo Cortez.(2007).

Fig. A Casa de Itamaracá-PE de Cydno da Silveira e Amélia Gama. 80

2.39 Disponível em:< www.csaarquitetura.com.br>.Acesso em:09.jun.2008 e o Refúgio de Hóspedes de Marcos (Reco) Borges, em Tiradentes-MG, fotos extraídas da Rev.Arquitetura \& Construção n.8. Ano 14, p.32-44

Fig. Exemplos de formas, desforma de adobes e secagem ao sol.Fotos: 82

2.41 Parisi,R.S.B. abril.2007 e Revitec.mar.2006.

Fig. Casa do Distrito de Valeriano Veloso (Bichinho), em Minas Gerais. Foto: 83 2.42 Parisi, R.S.B.abril.2005.

Fig. Casas de taipa de Maceió e Marechal Deodoro-AL.Fotos: Parisi,R.S.B. 88 2.43 jul.2006.

Fig. a imagem de outra casa bandeirista Do Itacolomy construída em terra 89

2.44 no século XVIII disponível em: http://www.parquedoitacolomi.com.br/bandeirista.jpg, acesso em: 10.mai.08. e da casa bandeirista de Itu-SP, disponível em: $<w w w . i t u . c o m . b r / c o l u n i s t a s / a r t i g o . a s p ? c o d \_c o n t e u d o=6896>$; $\quad$ acesso em: 15.mai.08.

Fig. A estrutura do esqueleto e entramado do bangalô contemporâneo de

2.45 Cydno da Silveira, e depois, a mesma casa concluída. Fotos: Silveira,C.Disponíveis em:< www.csa.arquitetura.com.br>. Acesso em: 
07.mai.2008.

Fig. Pinto Dias et al. Esboço geral e perspectivas da doença de Chagas no 92

2.46 Nordeste do Brasil (2000). Rio de Janeiro: Caderno de Saúde Pública 16 (Sup 2):p.13-34.; disponível em: < http://www.scielo.br/pdf/csp/v16s2/3481.pdf >; último acesso em: 14.mai.2008

Fig. Vista panorâmica da Fazenda Boa Vista, atual Reserva Xucuru-Kariri de

3.01 Caldas e a placa que faz referência ao Sistema de Abastecimento da reserva. Fotos: Humn, R. e Castañeda,G.N., em ago.2003 e set.2004.

Fig. Etapa de confecção do esqueleto da casa e cobertura de uma das

Fig. Etapa de confecção do alicerce ao esqueleto da casa e cobertura de

3.03 uma das casas. Fotos: Parisi,R.S.B e Carvalho, M.C. em nov.2004 e dez.2004.

Fig. Casas convencionais cobertas com telha cerâmica. Fotos: Parisi,R.S.B e 100

3.04 Miranda Jr, T. em nov.2004.

Fig. Confecção estrutura bambu e cobertura. Fotos: Parisi, R.S.B., nov.2004 101 3.05 e fev.2005.

Fig. Detalhe painel em'novaterra'. Produção LUZ,T. em jun.2008.

Fig. A palha triturada e utilizada nas casas, o amassamento e 102 3.07 preenchimento. Fotos: Fotos: Parisi, R.S.B., fev.2005 e mar.2005.

Fig. A tela, o chapisco e o início do revestimento. Fotos: Parisi, R.S.B., 103 3.08 mar.2005. e abr.2005

Fig. A Exposição Capiras,Capiaus:Pau-a-pique e algumas casas rurais da 104 3.09 obra de Marcelo Ferraz. FERRAZ,M.C. (1992) in Arquitetura Rural da Serra da Mantiqueira.

Fig. Imagens do chapisco, reboco, instalações hidráulicas e acabamento de 104

3.10 uma das casas em 'novaterra'.Fotos: Parisi,R.S.B e Loiola, L.S. marjunh.05.

Fig. Casa com forro de bambu. Publicada em

3.11 Brasil Terra Virgem n.99, disponível em: < http://www.vivercidades.org.br/publique222/cgi/cgilua.exe/sys/start.htm?i nfoid=1231\&sid=5\&tpl=printerview $>$ e $<$ http://www.asminasgerais.com.br/diamantina/venhameVERDEperto/02 bh diamantina via 7lagoas/thumb/ 020.jpg . Acesso em: 23. mai.2008.

Fig. Os experimentos sul-mexicanos. Fotos: Castañeda, G.N. em 2004. 
Fig.

\subsection{3}

Fig. A altura das casas de taipa de mão. Fotos: Parisi,R.S.B. jun.05 e 112 3.14 mai.06.

Fig. Aberturas fechadas e lacradas que demonstram a dificuldade de 112

3.15 adaptação dos índios em relação ao frio do sul de Minas Gerais. Fotos: Parisi,R.S.B., jun.05 e mai.06.

Fig. A habitação em 'novaterra' e a habitação convencional. Fotos: 119

3.16 Parisi,R.S.B., jun.05 e nov.06.

Fig. Carta solar e plantas com sensores. Produção LUZ.T,(2008). Jun.2008

$3.16 a$

Fig. Colocação dos Sensores e equipamentos para análises térmicas.

3.17. Fotos: Parisi, R.S.B e Castañeda, G, em out.2005

Fig. Casas e sensores da Reserva Xucuru. Produção LUZ.T,(2008). 123

3.18 Jun.2008

Fig. Tabelas de desempenho térmico do livro de MINKE,G.(2005). Manual de 132

3.19 construccíon com tierra. Op.Cit.

Fig. Casas e sensores da Reserva Xucuru. $2^{\circ}$ episódio. Produção 134 3.20. LUZ.T,(2008). Jun.2008

Fig As casas do Cajueiro Seco acabadas. Fonte: Imagem cedida pelo 145 4.01. Arquivo do Arquiteto Acácio Gil Borsói. Recife, 1963.

Fig. Casas rurais da Serra da Mantiqueira fotografadas pelo Arq. Marcelo 146 4.02. Carvalho Ferraz. Fonte: FERRAZ,M (1992). Arquitetura Rural da Serra da Mantiqueira.

Fig. A primeira casa de bajareque pertence ao Arq. Arturo Gonzalés e a 146 4.03 segunda, está construída na Universidad Autònoma de Chiapas. As duas estão construídas em Tuxtla-Gutierrez, capital do Estado de Chipas. Fotos: Parisi, R.S.B. set/2005.

Fig. Capa do Guia de Procedimentos. Criação e Lay Out. DIOGO,P.S e 148 4.04 CARVALHO,M.V.B. PUC-Poços de Caldas. Agosto.2008

Fig. Proposta vencedora do Concurso Caixa/IAB 2004. Disponível em: < 155 4.05a http://www.vitruvius.com.br/institucional/inst104/inst104 03.asp > acesso e e em: 27.mai.2008. 
Fig. Habitação indígena construída pela COHAPAR no Paraná.

4.06 Disponível em:

$<$ http://www.cohapar.pr.gov.br/cohapar/modules/xcgal/albums/userpics/1 0002/thumb cenario-09 p.jpg > acesso em: 25.mai.2008

Fig. Planta de casa indígena proposta pelo governo do Rio Grande do Sul.

4.07a Disponível

em:

<http://www.invi.uchile.cl/derechociudad/ponencias/ULACAV/Panel\%201

19.\%20Pinto\%20Cruz,\%20Tassinari\%20Cruz.pdf> acesso em:25.mai.2008

Fig. Corte, fachada e fotos da habitação indígena executada no Rio Grande 160

4.07b do Sul. Disponível em:

$<$ http://www.invi.uchile.cl/derechociudad/ponencias/ULACAV/Panel\%201

19.\%20Pinto\%20Cruz,\%20Tassinari\%20Cruz.pdf>> acesso em:25.mai.2008

Fig. Pro posta alternativa realizada pela Universidade para os índios da 161

4.08 aldeia Mybiá Guarani. Disponível em: < http://www.invi.uchile.cl/derechociudad/ponencias/ULACAV/Panel\%201/ 9.\%20Pinto\%20Cruz,\%20Tassinari\%20Cruz.pdf> acesso em 25. Mai.2008. 


\section{Resumo}

A pesquisa teve como propósito reconstituir a trajetória e a construção de novas habitações para um grupo de índios da etnia Xucuru-Kariri, remanejados do agreste alagoano para a Reserva de Caldas, município do sul de Minas, localizada na Fazenda Boa Vista, a 6 km da área urbana.

As habitações foram construídas empregando a 'terra armada', através de uma adaptação tecnológica do bajareque mexicano associado à taipa de mão ou pau-a-pique que passou a ser denominada como 'novaterra'.

Depois de concluídas as habitações, foram realizadas análises relativas ao desempenho térmico, com o objetivo de se estabelecerem comparações entre o desempenho térmico de uma das unidades de terra e o de uma habitação edificada no mesmo local empregando materiais convencionais. Em períodos distintos de primavera-verão e outono-inverno e em situações distintas - na ausência e com a presença de forros, as variações de temperatura foram aferidas junto aos dois tipos de construção.

Finalmente, entendeu-se a importância da elaboração de um "Guia de procedimentos da tecnologia adaptada", com o objetivo de disseminar seu emprego em habitações, principalmente em regime de autoconstrução. Também concluiu-se sobre o importante papel do emprego da 'novaterra' como reinterpretação das tecnologias de terra trazidas para o Brasil durante 0 período colonial, estabelecendo-se parâmetros para outras pesquisas sobre habitações sustentáveis e de baixo impacto para o meio ambiente.

Palavras-Chave: índios - habitação, terra-crua, condicionamento térmico e sustentabilidade. 


\section{Abstract}

The proposal of this study was to rebuild the path and build new houses for a Brazilian native Indian ethnic group Xucuru-Kariri, moved from the Alagoas countryside area (agreste) to the Caldas' reserve, located in a city in the south Minas Gerais, at the Boa Vista farm, $6 \mathrm{~km}$ from the urban area.

These new houses were earth-built through an adaptation from the Mexican bajareque technique associated with loam or lath-and-plaster, which was named 'novaterra'.

After the conclusion and occupation of the houses; in order to establish a thermal comparison, these novaterra houses' temperatures were measured and compared to custom built ones', also located in the Caldas' reserve.

In distinct periods of spring-summer and autumn-winter the thermal variations were measured in both building types, also in distinct situation - with and without ceiling.

For the purpose of disseminating this technique and its application, mainly in self- building, a procedure guide of this adapted technique was prepared.

In conclusion, the use of the 'novaterra' technique and its importance as as an understanding of earth building techniques brought to Brazil in the colonial period, were understood establishing parameters for the research of sustainable, and low environmental impact habitations.

Keywords: Indian (habitation), mud wall, thermal conditions, sustainability 


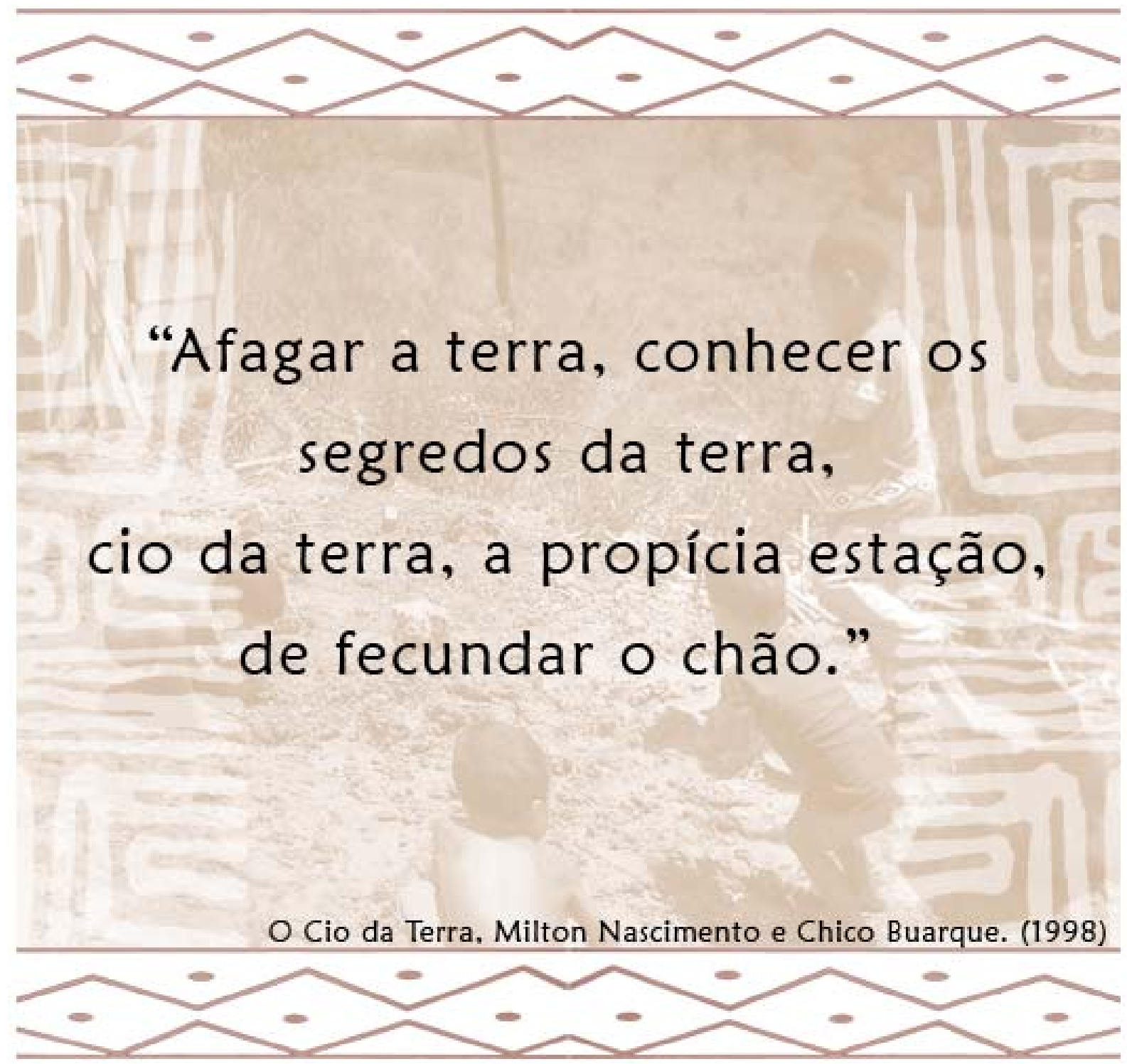

\subsection{Introdução}

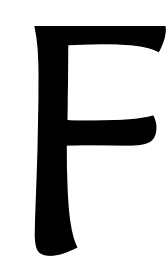

alar sobre moradia de baixa renda e, em particular, de moradias indígenas

no Brasil parece uma ironia: com o descaso dos governantes frente a essa

questão, as pesquisas individualizadas e espalhadas por instituições de

respeito em todo o território não atenuam a extensão e a complexidade do problema. 
Ainda que haja seriedade por parte de organismos e instituições como o Habitare Programa de Tecnologia para Habitação, que "tem por objetivo contribuir para o avanço do conhecimento no campo da tecnologia do ambiente construído, apoiando pesquisas científicas, tecnológicas e de inovação, visando o atendimento das necessidades de modernização do setor de habitação e contribuir para o atendimento das necessidades habitacionais do país", não se consegue atenuar a complexidade de problemas e dificuldades, também decorrentes das dimensões continentais do território brasileiro.

No que diz respeito à moradia indígena, o problema se amplia: a FUNAI e FUNASA, fundações que detêm a proteção e gerenciamento de recursos para a manutenção e proteção dos povos indígenas, ao longo de sua história, não se dedicaram a pensar com seriedade em formas de proteger, manter e melhorar as identidades construtivas dos povos e etnias espalhados por todo o país.

A pesquisa ora apresentada mapeou o percurso, o remanejamento e a trajetória de um grupo de índios Xucuru-Kariri ${ }^{1}$, deslocados de Palmeira dos Índios, na região agreste de Alagoas, no nordeste do Brasil, para o sul do Estado de Minas Gerais, na zona rural de Caldas, a cerca de 2000 km da região de sua origem.

Foi definido o foco principal de análise: a moradia dos mesmos, as formas de conquista e apropriação dos materiais, o agenciamento e a importância- ou não- que esses "abrigos" representaram e representam para o grupo, para que, ao se deparar com a necessidade de moradias em Caldas, a proposição de novas construções

\footnotetext{
${ }^{1}$ Encontrou-se a grafia do nome da etnia escrita de várias formas: Xukuru-Kariri; Xucuru-Kariri; Xucrús, entre outros. Adotou-se a forma Xucuru-Kariri, aquela que é mais utilizada.
} 
possibilitasse, em certa medida, reconstruir, simbolicamente, a identidade construtiva dos Xucuru-Kariri.

A pesquisa apresenta conclusões sobre o comportamento térmico de duas moradias : a primeira, concluída na Reserva Xucuru-Kariri em Caldas, quando o trabalho foi iniciado, construída com materiais convencionais, especificamente blocos de concreto, coberta com telhas de barro e revestida de reboco e uma outra construída a partir de 2002, onde houve o emprego da terra como seu material principal.

Foi desta forma que se chegou à 'novaterra' que, nas palavras do Cacique Uarkanã de Aruanã, José Sátiro do Nascimento, representa a conquista definitiva de um território, de um lugar ao sol, selando o fim de um período de mais de 18 anos de lutas pela posse definitiva de terra para um grupo de índios remanejados.

A 'novaterra', adaptação e melhoramento tecnológico do bajareque mexicano, da quincha peruana e da taipa de mão ou pau-a-pique brasileiro, possibilitou a construção das três moradias em terra crua e melhorou as condições de conforto e habitabilidade das famílias dos índios Xucuru transplantados.

Esta particularidade poderá ser observada no capítulo 3, a partir das avaliações experimentais do comportamento térmico de uma das moradias construídas em terra, quando comparada àquela construída com materiais convencionais, denominada na pesquisa como habitação 'testemunho'.

Foi possível constatar, ao longo dos mais de três anos ininterruptos de visitas à Reserva Xucuru-Kariri em Caldas que, na verdade, o grupo indígena em questão foi bastante aculturado em decorrência, dentre outros aspectos, dos sucessivos deslocamentos. 


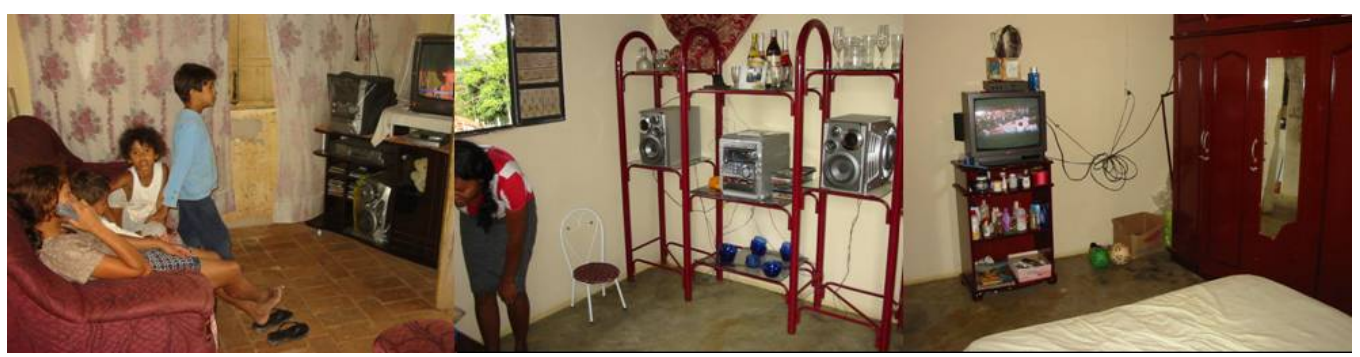

Fig. 1.01. O interior de duas habitações utilizadas pelos índios Xucuru-Kariri em Caldas e seus aparelhos eletroeletrônicos.

Impressionante observar na fig. 1.01 a quantidade de equipamentos eletroeletrônicos existentes em praticamente todas as casas da Reserva de Caldas, ainda que o estado de conservação da maioria dessas construções fosse precário.

Ao mesmo tempo, os índios deslumbraram-se em decorrência de um de seus membros ter se transformado em um misto de "ícone e ídolo" ao se separar da tribo 
e ir buscar a realização profissional através do futebol junto ao Esporte Clube

Corínthians Paulista e, depois, junto a outros clubes internacionais ${ }^{2}$.

A sedução pelos costumes e equipamentos tecnológicos e "modernos", pelos

hábitos e costumes da sociedade contemporânea midiatizada, vem fazendo que os

Xucuru se distanciem, cada vez mais, da identidade histórica e da identidade construtiva de seu povo ${ }^{3}$.

Mais que isso, ao se realizar uma avaliação das moradias construídas de forma convencional ou com a 'novaterra' na Reserva de Caldas se percebe, nitidamente, a falta de interesse em realizar manutenção preventiva para quaisquer moradias da aldeia. Esta falta de interesse, aliada aos diversificados 'sonhos de consumo' dos

2 Índio: Um campeão esquecido. José Sátiro do Nascimento, mais conhecido pela torcida corinthiana como Índio, nasceu no dia 3 de abril de 1979 em Palmeira dos Índios, Alagoas. Iniciou sua carreira nos juvenis do Vitória com 17 anos, e em torneio internacional disputado em Boston-EUA, chamou a atenção dos dirigentes do Corinthians que, animados com seu bom desempenho, logo o trouxeram para o Parque São Jorge, em 1998. Desembarcou em São Paulo como aposta futura e primeiramente foi integrado à equipe de base, mas,com o sucesso imediato do jovem elenco vencedor, subiu à equipe principal juntamente com Edu, Gil, Éwerthon, Kleber e companhia. Iniciando na reserva do até então titular Rodrigo, fez bons jogos e, com sua regularidade, assumiu a posição de titular, sendo importante na campanha vitoriosa do Corinthians no campeonato brasileiro de 1998. Em 1999, já como titular absoluto, sagrou-se campeão paulista diante do Palmeiras e novamente campeão brasileiro. Índio não era unanimidade entre os torcedores. O ataque não era sua principal arma, porém gozava de muita raça e determinação, tornando-se assim um lateral mais defensivo que ofensivo. Tais características, somadas, sempre o ajudaram a obter vantagem na disputa pela camisa titular com Rodrigo, e algum tempo depois, com César Prates, ambos com funções mais ofensivas. Em pouco tempo no Corinthians, Índio conquistou diversos títulos, mas a glória principal chegou em janeiro de 2000, quando juntamente com uma equipe praticamente imbatível conquistou o Mundial de Clubes da FIFA, contra o Vasco, em pleno Maracanã. Após o grandioso e inédito título, houve no Parque São Jorge o conhecido "desmanche", já esperado, e Índio foi negociado com o Seul, clube do futebol coreano. Alguns meses na Ásia e nenhum sucesso como os do tempo de Corinthians. Retornou ao Brasil para então atuar pelo emergente Goiás, por empréstimo. No clube goiano o ex-lateral do Corinthians obteve poucas chances, retornando assim para o Seul. Na Ásia, por incrível que pareça, Índio tornou-se ídolo e, além do Seul, o lateral jogou por mais dois clubes coreanos. Atuou nos gramados asiáticos de 2001 a 2003 e em 2004 retornou de vez ao Brasil. Hoje, (foi) casado, com 28 anos e sem clube, Índio busca mais um desafio em sua carreira. Atualmente reside na cidade de Poços de Caldas-MG., foi dono de um restaurante e ainda continua batendo sua bola nos finais de semana. O ex-jogador do Corinthians convive também com mais de 10 familiares de sua tribo e juntos seguem suas vidas no Sul de Minas Gerais, mas jamais esquecendo sua passagem pelo Sport Club Corinthians Paulista. Informações retiradas de <http://diadejogo.blog.terra.com.br/2007/03/> Acesso em: 27.dez.2007. Conforme informações do Cacique, pai do Índio, seu filho não chegou a se casar como dizia a reportagem. Seu restaurante funcionou por cerca de um ano e, desde o final de 2007, Índio trabalhou como técnico de futebol em Brasília, em Goiás e atualmente, em São Paulo, aguarda a assinatura de um contrato com um time 'importante'.

${ }^{3}$ Este tema foi objeto de Monografia: "Modos de Morar dos ìndios Xucuru-Kariri em Caldas: reinventando a 'novaterra' ", apresentada em dezembro de 2004 para a conclusão da disciplina: SAP 5846: Habitação, Metrópoles e Modos de Vida, sob a responsabilidade do Prof.Dr. Marcelo Tramontano 
cerca de noventa e cinco moradores da Reserva de Caldas, acaba por apontar que a moradia, sua qualidade e as condições de habitabilidade, infelizmente, não são as maiores preocupações do grupo indígena.

Percebe-se que os Xucuru-Kariri valorizam efetivamente a posse da terra e lutam, insistentemente, pela destinação de recursos e uma certa manutenção de comodismos $^{4}$ por parte dos organismos político-governamentais e agências de proteção aos povos indígenas. Transferem, ainda, essas solicitações a quaisquer grupos e entidades que se aproximam da Reserva Indígena: assim também aconteceu desde o momento da primeira aproximação de professores da PUCMinas, campus de Poços de Caldas dos índios Xucuru-Kariri assentados em Caldas.

Independentemente do quadro ora apresentado, a presente pesquisa concentrou, na análise das duas moradias referidas, o seu foco de avaliações e de experimentação, ou seja, uma moradia construída em blocos de concreto de forma convencional e uma das unidades de habitação construída em 'novaterra' com recursos advindos da Cáritas Brasileira ${ }^{5}$ através da Mitra Diocesana de Guaxupé e da PUC-Minas.

Desta maneira, o primeiro capítulo aborda a importância, o histórico e as considerações sobre a investigação proposta e, em especial, resgata as formas de morar dos Xucuru-Kariri, desde o aparecimento da etnia por volta do ano de 1820,

\footnotetext{
${ }^{4}$ De acordo com o Cacique José Sátiro em entrevista ao jornalista Ricardo Kotscho para a Revista Época, Especial para 24/04/2000:"Não era para estar aqui pedindo terra a branco. Branco é que deveria pedir terra para nós. Nós chegamos antes. E agora estamos aqui pagando aluguel. Isso é um absurdo."

${ }^{5}$ A Cáritas Brasileira faz parte da Rede Cáritas Internationalis, rede da Igreja Católica de atuação social composta por 162 organizações presentes em 200 países e territórios, com sede em Roma. Organismo da CNBB - Conferência Nacional dos Bispos do Brasil foi criada em 12 de novembro de 1956 e é reconhecida como de utilidade pública federal.
} 
no século XIX, junto do município de Palmeira dos Índios-AL, até a proposição da moradia em 'novaterra', quando os Xucuru já estavam definitivamente assentados em Caldas.

Apesar de as solicitações de novas habitações terem sido iniciadas logo após o primeiro contato entre a PUC-Minas e os índios, o processo construtivo foi deflagrado, efetivamente, em 2004, com sucessivas complementações que ocorreram até o final do ano de 2007.

Ainda no primeiro capítulo, realiza-se uma série de investigações sobre a temática da moradia indígena e a atuação dos órgãos governamentais frente à questão. Em especial, apresentam-se considerações sobre as moradias indígenas em terra, traçando-se um paralelo entre sua permanência e a manutenção da identidade construtiva em terra no Brasil.

Já o segundo capítulo se detém a descrever a metodologia de pesquisa, os procedimentos construtivos, as dificuldades e a concretização das moradias, bem como a definição dos parâmetros para a avaliação do comportamento térmico das moradias, assunto que será trabalhado no terceiro capítulo deste trabalho. Ao final, são apresentadas características do sistema construtivo empregado nas habitações Xucuru-Kariri, mostrando-se ainda a posição convenientemente hoje empregada através da aproximação entre os modelos de projetos rurais e os modelos de projetos urbanos. Investiga-se, ainda, em que medida a proposição da 'novaterra' abre perspectiva de transferência de uma tecnologia de qualidade e baixo custo, como forma de releitura de uma identidade construtiva mais antiga desses índios. 
Ainda sobre a metodologia, com o suporte da climatologia dinâmica para a Reserva de Caldas, foram definidos os episódios representativos de fato climático e o dia representativo experimental para uma situação de calor e de frio, durante os períodos dos três anos em que foram realizadas as avaliações de temperatura e umidade, que serão abordados no terceiro capítulo.

O terceiro capítulo descreve o comportamento térmico de duas habitações na Reserva Xucuru-Kariri de Caldas. Trata-se de descrição detalhada do comportamento da temperatura do ar, no interior das casas, em relação à temperatura externa, cujos resultados são apresentados de acordo com os seguintes critérios:

1. descrição e avaliação de um episódio representativo do tempo (meteorológico) de transição primavera-verão de 31 de outubro a 10 de novembro de 2005, na Reserva; 2. descrição e avaliação de um episódio representativo entre os dias 11 e 31 de maio de 2006;

3. descrição e avaliação de um episódio representativo de verão especificamente entre o período de 04 até o dia 21 de dezembro de $2007^{6}$;

4. descrição da curva (tempo/temperatura) das temperaturas internas do ar (temperatura de bulbo seco - tbs) da casa de bloco, ou 'habitação testemunho,' e da casa de 'novaterra';

5. descrição comparativa entre as duas habitações com monitoramento de temperatura superficiais (tsi) em relação à Radiação Solar Global, identificando,

\footnotetext{
${ }^{6}$ A definição das datas para a realização das análises térmicas ocorreu de acordo com a disponibilidade de equipamentos para tais procedimentos. Durante o primeiro foram utilizados equipamentos HOBO da UNACHMX, disponibilizados pelo colega e professor Doutorando Gabriel Castañeda Nolasco. Para as avaliações subseqüentes, a PUC-Minas adquiriu equipamentos HOBO e seus respectivos dataloggers e programa computacional Boxcar. No entanto, para as análises de temperatura externas, foram considerados os registros realizados na Estação Experimental da EPAMIG, em Caldas, distante $6 \mathrm{~km}$ da Reserva Indígena e os registros de dados climáticos (temperatura, umidade, direção de ventos) disponibilizados pela INFRAERO colhidos no Aeroporto de Poços de Caldas, distante cerca de $30 \mathrm{~km}$ da área da Reserva de Caldas.
} 
sempre, propriedades, potencialidades e características dos dois sistemas construtivos empregados nas moradias de Caldas.

Ao final, a pesquisa incorpora, depois de verificar problemas e soluções para o aprimoramento da 'novaterra' da Reserva Xucuru-Kariri, um guia de procedimentos, desde a análise de solo até a cobertura e manutenção da edificação, com o objetivo de disseminar, de maneira prática e didática, a utilização da tecnologia da 'novaterra'. Este guia poderá servir de referência para ser aplicado em programas auto-gestionários de moradias de baixa renda, assim como, e por que não, sempre com revisões contextualizadas, em ampliações e novas habitações rurais ou indígenas em que se identifique e se eleja, previamente, o emprego da terra como material de construção renovável, seguro, confortável, ecológico e sustentável.

\subsection{Justificativas}

Quando se pensa em habitação indígena na contemporaneidade brasileira, em especial no que diz respeito aos grupos localizados em áreas mais próximas de centros urbanos consolidados, não é muito simples apontar que tipo de conduta seria melhor para promover novas habitações. Os exemplos encontrados apontam ou para a reprodução de modelos urbanos pré-estabelecidos ou para a criação de 'receitas' que parecem trazer de volta a estereotipada oca.

Ao mesmo tempo, conforme aponta FIALHO (2005), "entre as últimas décadas de 80 e 90, é possível perceber uma mudança nos pleitos dos povos indígenas. A década de 80 foi marcada pela mobilização dos mesmos no sentido de garantir seus direitos 
territoriais $^{7}$. Na década seguinte, já aos auspícios da nova Constituição Federal, as reivindicações indígenas começaram a ser caracterizadas por demandas mais amplas, exigindo políticas públicas que viabilizassem a gestão e o controle de seus territórios, a sustentabilidade de suas populações, além da estruturação de um sistema educacional e de saúde diferenciados, afeitos às suas especificidades sócioculturais". Porém, conforme pode se observar no desenvolvimento da presente pesquisa, ainda que a interlocução se faça cada vez mais presente, ainda que as sociedades indígenas procurem cada vez mais se articular, mobilizar e fazerreconhecidas, a questão da habitação continua, infelizmente, relegada a um segundo plano.

Diante deste quadro se fazem necessárias ações efetivas que discutam com os índios a produção de habitações que possam também referendar o papel da preservação das identidades culturais de cada uma das etnias indígenas.

Trilhando por este caminho, a produção das habitações em 'novaterra' se justifica, uma vez que busca resgatar a identidade e tradição construtiva dos Xucuru-Kariri, considerados, assim como as demais etnias nordestinas como índios misturados. Conforme apontam OLIVEIRA (2003) e FIALHO (2005), "essa é uma categoria que tenta dar conta das peculiaridades dos processos de territorialização e de afirmação étnica dos indígenas nordestinos e são contemplados pelas ações de organismos governamentais e não-governamentais por sua direta relação com a pobreza no meio rural e não por suas potencialidades organizativas e culturais".

\footnotetext{
${ }^{7}$ A partir dos Artigos 231 e 232 da Constituição Federal de 1988, os indígenas são considerados atores juridicamente capazes para entrar em juízo, através de suas organizações, rompendo com o status que lhes fora atribuído pelo Artigo $6^{\circ}$ do Código Civil de 1916.
} 
A pesquisa se justifica frente à preferência manifestada pela população indígena em habitar as edificações construídas em terra, especialmente aquelas construídas com a 'novaterra'8, como também pela ausência de informações sobre as propriedades termofísicas dos materiais utilizados na construção de casas em terra crua e ausência de avaliações experimentais específicas para moradias que possibilitem, no Brasil, a determinação de parâmetros que possam facilitar e contemplar a sustentabilidade de habitações em terra. Em um momento em que cada vez mais se discutem os danos provocados pelas construções convencionais e se procuram caminhos para reverter os estragos provocados ao meio ambiente pelos homens, a proposição de habitações em terra, com qualidades e potencialidades avaliadas durante a pesquisa, certamente, poderá ser aplicada em outras experiências também satisfatórias, que contribuam para o estabelecimento de um cenário menos desigual, com mais qualidades, mais adequado às necessidades e anseios dos grupos indígenas e, por que não, de outras comunidades marginalizadas.

Diante do fato inédito de haver índios transplantados e adaptados espontaneamente no sul de Minas Gerais e diante das formas de apropriação do espaço rural por esses índios, surgiu a necessidade de se produzirem, neste novo território, habitações confortáveis tanto no verão quanto no inverno.

A opção encontrada foi construir uma habitação em terra que se configurava como adaptação e melhoramento tecnológico que aprimorava a já conhecida taipa de mão

\footnotetext{
${ }^{8}$ A família do Sr.José Pinto -Da.Ivonete (D.a Netinha), cunhada do Cacique, constituída de 11 pessoas, foi a primeira a residir na maior casa concluída em 'novaterra'. Quando questionados sobre as diferenças entre morar nesta casa e naquela que anteriormente residiam, afirmaram que esta é mais quentinha, principalmente depois da colocação do forro. É também uma casa arejada, que nos quartos batem sol, o que não ocorria na outra casa, reforçando o fato de as edificações construídas em terra apresentarem desempenho térmico favorável, conforme observa MINKE (1997), o que será amplamente discutido no capítulo referente ao desempenho térmico das habitações.
} 
dos índios. Importante ainda pensar que, ao dominar a 'novaterra', os índios poderiam realizar, sempre que necessárias modificações deste sistema construtivo tanto em suas próprias habitações quanto em outras edificações e em propriedades rurais da redondeza, promovendo para si mesmos uma forma de geração de renda através de um trabalho diferenciado, inovador, simples de ser realizado, pois com facilidade aprenderam e que gera qualidade construtiva.

Reforçando o propósito e a importância da disseminação de uma tecnologia natural e sustentável, através de CÂNDIDO(1992/1996), pode-se perceber que, se posturas semelhantes não forem tomadas, "a moderna cultura urbana está impondo depressa demais um novo meio e uma realidade nova, de tendência incrivelmente homogeneizadora, dominada pelo artefato em série fria, onde quase não há mais a água solta, o verde, a ladeira e sua lama, o vento no arvoredo, o irmão boi pastando com sossego, nem a marcha picada dos bons cavalos. Mas o pior é que também já vão ficando vasqueiras tanto a solidariedade dos vizinhos, quanto as visitas entre amigos e as festas periódicas que reforçam os laços. É possível imaginar que dentro de algum tempo não haverá mais leite, verdura ou ovo, substituídos por sintéticos equivalentes, e que desgraçadamente não haverá também paciência com o semelhante, ânimo de socorro e alegria com as coisas simples".

Por essa razão, a estratégia de adoção da releitura da taipa de mão, a 'novaterra', pode promover o uso equilibrado de recursos disponíveis e, portanto, a 
sustentabilidade ${ }^{9}$.

Espera-se que as novas moradias, resultado de um aprimoramento de tecnologia, possam ser vistas como sinônimo de qualidade construtiva e de ambiente saudável. A comprovação científica dos aspectos construtivos e da qualidade térmica das moradias acabou se configurando como uma condição que se estabeleceu durante o processo de construção. Como afirmado anteriormente, membros de uma família que habitava uma casa construída de forma convencional disseram que a nova casa, construída em 'novaterra', é menos fria e mais aconchegante.

Um fato importante que deve ser apresentado é que não foram encontrados registros de trabalhos de pesquisa em que tenham sido feitas avaliações térmicas junto a moradias construídas em terra crua através de experimentações in loco, com aparelhos do tipo HOBO, que serão caracterizados oportunamente no trabalho.

Também não foram encontradas orientações para que tais moradias pudessem se tornar efetivamente mais econômicas, agradáveis, saudáveis e sustentáveis, o que por si só justifica a possibilidade de, através da experiência construtiva, junto com a avaliação dos registros de temperatura e umidade, estabelecer parâmetros que reforcem ou rechacem o emprego da adaptação denominada 'novaterra'.

\footnotetext{
${ }^{9}$ O conceito de sustentabilidade nasceu dentro de um relatório elaborado pela ONU em 1987, denominado "Nosso Futuro Comum". Tal relatório se configurava não só como um protesto, mais ainda, como uma reflexão sobre o acidente de Chernobyl, ocorrido em 1986. Neste documento, a Organização das Nações Unidades se posicionava sobre o comportamento predatório do desenvolvimento econômico e a Comissão Mundial sobre o Meio Ambiente e Desenvolvimento (CMMAD) criticava o modelo adotado pelos países desenvolvidos e defendia um novo tipo de desenvolvimento, capaz de manter o progresso em todo o planeta e de, no longo prazo, partilhálo entre países em desenvolvimento e desenvolvidos. Ou seja, este é um conceito que se refere a um tipo de desenvolvimento capaz de atender às necessidades da geração atual sem comprometer os recursos necessários para satisfação das necessidades das gerações futuras. De acordo com De CAMINO \& MULLER (1993), "a sustentabilidade ecológica implica na manutenção no tempo das características fundamentais de um ecossistema sob uso quanto aos seus componentes e suas interações; a sustentabilidade econômica se traduz através de uma rentabilidade estável no tempo e a sustentabilidade social está associada a idéia de que o manejo e a organização do sistema são compatíveis com os valores culturais e éticos do grupo envolvido e da sociedade ..." . Na visão do físico e escritor Frtjjof Capra, uma "Comunidade Humana Sustentável é aquela que não interfere na habilidade inerente à natureza de sustentar a vida".
} 
Ao levantar questões polêmicas sobre os povos indígenas do Nordeste, OLIVEIRA (1994) menciona que as etnias e culturas passam a ser descritas apenas pelo que foram há séculos atrás, mas sabe-se nada (ou muito pouco) sobre o que são hoje em dia. Tal afirmação gera um forte indício para a justificativa de que a reconstituição da trajetória do grupo indígena Xucuru-Kariri tem um importante significado nos dias atuais.

Por último, a presente pesquisa se justifica também através de fatores específicos:

1. A reinterpretação ou adaptação da tecnologia de taipa de mão ou pau-a-pique, como já enfatizado em tópicos anteriores, embora haja afirmações de que possa ter sido encontrada entre os povos indígenas, trazida pelos colonizadores portugueses, resgata e reaviva um antigo processo construtivo que há muito deixou se ser utilizado de forma corrente.

2. Os resultados da reinterpretação e de sua avaliação térmica abrem a possibilidade de disseminação de um sistema construtivo que emprega, em sua essência, materiais naturais, de reuso, e uma pequena quantidade de materiais industrializados que, por si só, agregam a sustentabilidade, já que se implantam em consonância e equilíbrio com o meio ambiente.

3. A 'novaterra' pressupõe projetos modulares, como se observará no capítulo específico à compreensão da tecnologia, onde são possíveis diversos tipos de concepções projetuais e arranjos que levam em conta a orientação solar, as necessidades específicas de cada programa ou uso, a implantação da edificação no terreno, a topografia, o que, entre outros aspectos, pode ampliar sua viabilidade construtiva. 
4. Tanto a proposta projetual como a construção das habitações em 'novaterra' levaram em consideração aquilo que a Organização Mundial de Saúde - (OMS) denomina como qualidade para moradias, onde se procura atender a quatro tópicos determinados que definem as moradias saudáveis ${ }^{10}$.

Pretende-se que a experiência da 'novaterra' como tecnologia ecológica e sustentável possa, além de ser disseminada e reproduzida, possa despertar o interesse de grupos diversos para a sua utilização, ainda que haja necessárias contextualizações e modificações. Quaisquer que sejam as construções para atender às necessidades de morar de grupos específicos, como o caso do grupo indígena que é objeto de estudo dessa pesquisa, ou quaisquer outros grupos, associações de bairro, comunidades ou organizações, mutirões urbanos ou rurais, sitiantes ou moradores urbanos, poderão ao final, conhecer, aperfeiçoar e experimentar os benefícios da tecnologia da 'novaterra'.

\section{3- Objetivos}

O objetivo principal deste trabalho é investigar o processo de remanejamento dos índios Xucuru-Kariri do Estado de Alagoas até o sul de Minas Gerais, identificando os motivos que os levaram a deixar o habitat natural e, por fim, apresentar

\footnotetext{
10 A Organização Mundial de Saúde utiliza 4 (quatro) parâmetros para definir as moradias saudáveis: 1. Satisfação de necessidades fisiológicas garantida através da ventilação adequada, iluminação natural e artificial suficientes, provisão de hortas, jardins e pomares. 2. Satisfação das necessidades psicológicas, possibilidade através da existência de ambientes para intimidade, de espaços na habitação que possibilitem as relações sociais e onde haja limpeza e comodidade. 3. Proteção contra a transmissão de enfermidades, concretizada através da disponibilidade de água potável, do tratamento dos excrementos, do domínio da fauna transmissora, de espaços para a armazenagem e conservação dos alimentos e da provisão de ar suficiente nos dormitórios, ou seja, 4,5m3 por cama, com camas que tenham um espaçamento entre si $=$ a $0,90 \mathrm{~m}$ além da proteção das superfícies interiores contra águas residuais (umidade) e altura de tetos igual a um mínimo de 2,30 a 2,40m com paredes e tetos livres de molduras para que seja facilitada a limpeza e por último. 4. Da proteção contra acidentes que se dá através da utilização de materiais que garantam a segurança. Disponível em: $<$ www.opas.org.br/ambiente/ temas.cfm?id=34\&area=Conceito $>$ acesso em:07.out.2006.
} 
proposições para promover sua fixação no habitat atual. Como forma de responder às necessidades ora expostas, foi realizada a intervenção através da construção de três novas unidades de habitação com o emprego da terra, entendendo que a Arquitetura de Terra faz parte da construção da história das habitações no Brasil, assim como faz parte da história construtiva dos Xucuru-Kariri, e, conseqüentemente, deve ser revisitada, resgatada e reinterpretada.

A pesquisa avaliou conceitualmente e experimentalmente o processo construtivo proposto para as novas habitações indígenas, observando os critérios desejáveis e os recomendados para uma tarefa de tal envergadura, pela ONU(1986), para a sustentabilidade do habitat construído.

Através do COHRE (Legal Resources for Housing Rights) de Gênova (2000), foi possível se ter uma visão mais ampla sobre os instrumentos e padrões internacionais relativos ao direito à moradia adequada.

Conforme apontam ALFONSIN E FERNANDES (2004), no interior dos Comentários de $\mathrm{n}^{\circ} 4$ e $\mathrm{n}^{\circ} 7$ do Comitê das Nações Unidas de Direitos Econômicos, Sociais e Culturais e, em especial, no Comentário $n^{\circ} 4$, é que estão definidos os elementos de direito à moradia que devem ser objeto de proteção e garantia. São eles:

a) segurança jurídica de posse;

b) disponibilidade de serviços e infra-estrutura; 
c) custo de moradia acessível: adoção de medidas para garantir a proporcionalidade entre os gastos com a habitação e a renda das pessoas, criação de subsídios e financiamentos para os grupos sociais de baixa renda;

d) habitabilidade: a moradia ou habitat deve ser habitável, tendo condições de saúde física e de salubridade adequadas;

e) acessibilidade: constituir políticas habitacionais contemplando os grupos vulneráveis, como portadores de deficiências, os grupos sociais empobrecidos, vítimas de desastres naturais ou de violência urbana, conflitos armados;

f) localização: moradia adequada significa estar localizada em lugares que permitam acesso às opções de emprego, transporte público eficiente, serviços de saúde, escola e lazer;

g) adequação cultural: respeito à produção social do habitat, à diversidade cultural, aos padrões habitacionais oriundos dos usos e costumes das comunidades e grupos sociais.

Além do objetivo de investigar o processo de remanejamento indígena e, ao mesmo tempo, apresentar proposições para promover sua fixação ao habitat atual, o trabalho atentou para a produção de moradias dignas, sustentáveis, que se consolidam em sintonia não só com os padrões preconizados pelos organismos internacionais e que, mais que isso, se concretizam com o propósito do respeito e da reconstrução de uma identidade construtiva, histórica e cultural. 


\subsection{1- Objetivos Específicos}

Durante o desenvolvimento do trabalho, os objetivos específicos discriminados a seguir se consolidaram, conforme será possível observar nos capítulos subseqüentes:

a. Estudar como moravam os Xucuru-Kariri em seu habitat original: como viabilizavam as moradias; que materiais empregavam; o processo construtivo, a resistência, a durabilidade e o conforto de suas moradias.

b. Investigar o processo de deslocamento dos índios em busca de uma terra melhor, um local onde poderiam definitivamente viver e abrigar todos os membros do grupo étnico.

c. Verificar as condições das moradias existentes no local para onde foram transplantados no momento de sua fixação nesse território.

d. Discutir, conscientizar e envolver o grupo indígena na implantação de um sistema construtivo que pudesse contribuir qualitativamente para sua fixação, em condições adversas àquelas que originalmente possuíam.

e. Investigar, com a conclusão das moradias, que qualidades as mesmas possuem no que diz respeito à concepção projetual e conforto do ambiente construído.

f. Investigar a adaptação e o melhoramento tecnológico introduzidos nas habitações em terra encontradas que desencadearam a concepção e a implantação da 'novaterra'.

g. Verificar, experimentalmente, os atributos das novas moradias quanto ao conforto térmico e sustentabilidade. 
Adentrando à temática do trabalho, apresenta-se a seguir um panorama dos povos indígenas do Brasil , em seguida, os índios do Nordeste e finalmente a etnia XucuruKariri. 


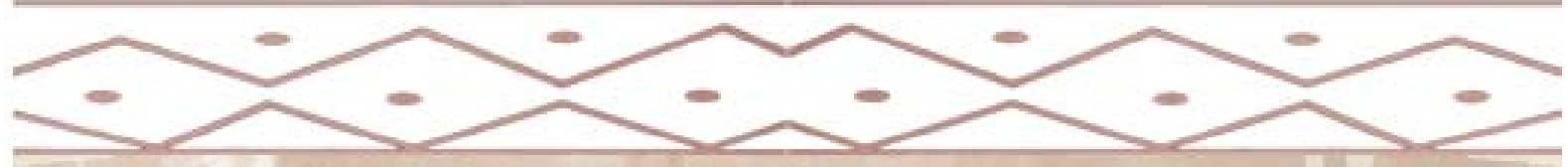

"Em verdade não chegamos a nos "transformar" em índios. Entretanto, o que nos impressionou, ao longo do convívio com eles, foi observar uma verdadeira lição de como se deve viver em sociedade.

Nunca vimos dois índios discutirem, nem um casal se desentender. Entre os índios, o velho é o dono da história, o homem é o dono da aldeia, e a criança é a dona do mundo".

Orlando Villas Boas, falando sobre o fato de seus irmāos Cláudio, Leonardo e Álvaro e ele mesmo, depois de tantos anos vivendo na selva com os índios.

nāo terem se transformado em um deles, (Entrevista publicada em 10.abr.2001)

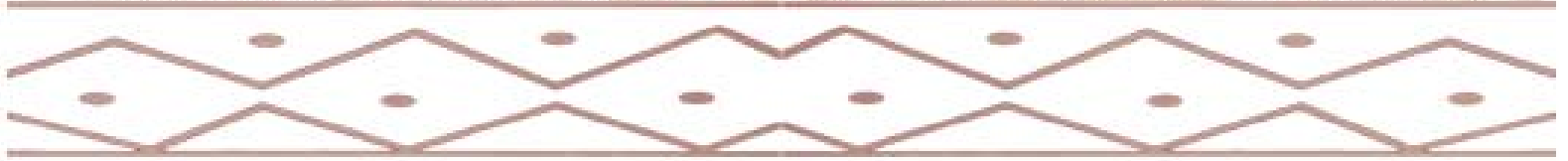

\subsection{Povos Indígenas no Brasil- breve histórico}

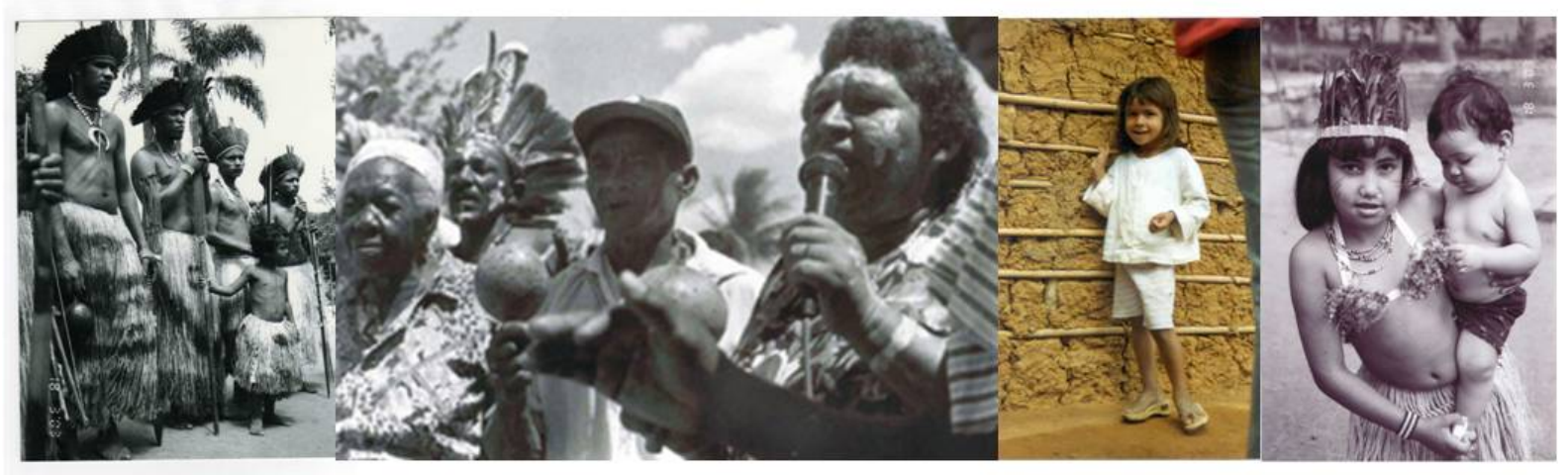

Fig. 2.01. Índios do Nordeste e índios Xucuru. 
"Seres sem fé, sem rei e sem lei" Maria Helena Chauí

Por que, com tanta terra abundante, com cursos d'água límpidos e cristalinos, além de flora e fauna exuberantes, as 'criaturas nativas' haveriam de se organizar em sociedades complexamente estratificadas, como as sociedades européias de então?

Segundo Chauí (2005), a maior parte das descrições dos nativos encontrados desde a época do descobrimento da América faz menção a seres fortes, livres e belos. "As descrições de Vespúcio, mais do que as dos outros, são de deslumbramento, particularmente quando se referem aos homens jovens e às mulheres. A imagem dos índios não é casual: os primeiros navegantes estão convencidos de que aportaram no Paraíso Terrestre e descrevem as criaturas belas e inocentes que viveriam nas cercanias paradisíacas". Mais adiante, no mesmo texto, a autora comenta que "no século XVIII fazendo a crítica iluminista da civilização e anunciando o romantismo, Rousseau construiu a figura do bom-selvagem, onde apenas concluiu um caminho aberto no final do século XV. Contraposta à imagem boa e bela dos nativos, a ação da conquista ergueu uma outra, avessa e negação da primeira.

Agora os "índios" são traiçoeiros, bárbaros, indolentes, pagãos, imprestáveis e perigosos. Postos sob o signo da barbárie, deveriam ser escravizados, evangelizados e, quando necessário, exterminados". Porém, se percebe, como enfatiza a autora e é fato, "que os pós-colombianos e pós-cabralinos realizaram a obra da dominação, mesmo quando julgaram que faziam o contrário, desejosos de aumentar o rebanho do povo de Deus ou os cidadãos da sociedade moderna".

Ainda hoje, no Brasil, passados mais de 500 anos de colonização, com informações e avanços empreendidos pelos indigenistas históricos, de Rondon aos irmãos Villas 
Boas, passando ainda pela pesquisa de Gilberto Freyre e Darcy Ribeiro que, com tamanha legitimidade, inventariaram e reconstruíram matrizes de um Povo Brasileiro, a cultura brasileira, conforme aponta SANTOS(2005), "permanece impermeável aos saberes indígenas, sua sociabilidade, mitos, artes e técnicas. O país se representou muitas vezes em vários planos, na figura dos índios sob seus mais diversos matizes, como pode se observar na fig. 2.01. No entanto, sua presença se mantém obscura, apagada e silenciosa, e sua cultura, ignorada e desprezada". Desta maneira, parte da matriz que constituiu o início do processo de estruturação da identidade brasileira, especificamente indígena foi, infelizmente, destruída.

Conforme aponta SÁ (1982-2) "as sociedades indígenas, às vezes também chamadas simples ou primitivas, apresentam grandes diferenças entre si, mas têm em comum o fato de serem culturalmente bastante estáveis, isto é, de conservarem longamente suas tradições, ainda que, como qualquer outra sociedade, estejam em permanente transformação, apenas em ritmo bastante lento.

\subsection{O contexto da Habitação Indígena}

Ao empreender esforços para conhecer mais sobre as moradias indígenas, durante a pesquisa foram encontrados dados segmentados, tanto no que diz respeito às diversas configurações dos povos indígenas e das habitações indígenas brasileiras quanto no que diz respeito às habitações especificamente Xucuru-Kariri.

SÁ (1982) também afirma que um processo cumulativo de pequenas alterações começa a agir, provocando modificações sensíveis em intervalos de tempo que variam conforme a sociedade indígena, o segmento representativo da sociedade 
envolvente e o tipo de contato estabelecido. Essas modificações tendem a aumentar sempre, levando a soluções intermediárias, a compromissos entre tradição e inovação e, até mesmo, ao surgimento de novos padrões de habitação. Por esse motivo a habitação indígena é geralmente considerada como sendo facilmente alterada pela situação de contato com a sociedade nacional envolvente.

Ampliando a afirmação de SANTOS (2005:30) mencionada anteriormente acerca do número de povos indígenas, de acordo com o Instituto Sócio-Ambiental (2008), há no Brasil cerca de 227 povos indígenas. "A lista de povos também pode ser alterada devido ao aparecimento de novas etnias, seja quando se encontram índios "isolados", seja por meio das chamadas "identidades emergentes". Se esses fatores podem fazer com que a lista aumente, ela também pode diminuir, já que o risco de extinção de grupos inteiros não está totalmente afastado. Como agravante, a maioria das etnias é conhecida por mais de um nome".

Como já afirmado, as análises dos trabalhos encontrados que falam do tema habitação indígena não forneceram informações abrangentes.

De acordo com BITTENCOURT (2005), "com um estilo de vida comunitário onde toda a propriedade é dividida igualmente, com casas onde habitavam várias famílias compartilhando tudo, com costumes sem paralelo com a experiência européia, os indígenas vão merecer descrições que demonstram uma atitude atônita de quem não compreende bem o que descreve". 
No trabalho organizado por MONTEZUMA (2002), sobre os 500 anos da Arquitetura Brasileira, a Arquitetura Indígena ficou a cargo de DERANJI(2002:026), que aponta para o fato de os aspectos relativos à construção, quando se fala dos povos indígenas, serem pouco esclarecedores. Este autor comenta: "trabalhos mais recentes, ainda que em pequeno número, começam a aprofundar o estudo das características construtivas das habitações indígenas, associando-as às crenças e aos mitos de cada povo".

De acordo com ELIAS (2000) ${ }^{1}$, "seguindo a descrição de Caminha, somente em um segundo dia de caminhada é que os portugueses puderam conhecer uma aldeia indígena, afastada da costa e protegida dos inimigos" (...) "e segundo eles diziam, foram bem uma légua e meia a uma povoação, em que haveria nove ou dez casas, as quais eram tão compridas, cada uma, como esta nau capitânia. Eram de madeira e de ilhargas de madeira e cobertas de palha, de razoada altura; todas duma só peça, sem nenhum repartimento, tinham dentro muitos esteios e, de esteio a esteio, uma rede atada pelos cabos, alta, em que dormiam".

A análise dos arranjos e produção da moradia dos nativos será permeada por lacunas. "Ainda assim, uma narrativa importante do período do descobrimento é a minuciosa obra de Jean de Léry". No entanto, apesar da minúcia sobre os costumes e a forma de vida dos indígenas, o autor não faz nenhuma referência às habitações construídas por eles, conforme sentencia DERANJI (2002: 028).

\footnotetext{
${ }^{1}$ Elias, Juliana Lopes apud Cortesão, J. p. 167. Moradia Indígena: Resistência dos Índios americanos in índios do Nordeste: Temas e Problemas 2. Almeida L.S, Galindo, M. e Elias, J.L. Maceió: EDUFAL, 2000, p. 231.
} 
Como pode se observar na fig. 2.02, as primeiras ilustrações que mostram algumas habitações destes primitivos habitantes estão nas gravuras que o soldado e marinheiro alemão Hans Staden, elaborou durante as duas viagens ao Brasil, entre 1548 e 1557, aproximadamente.

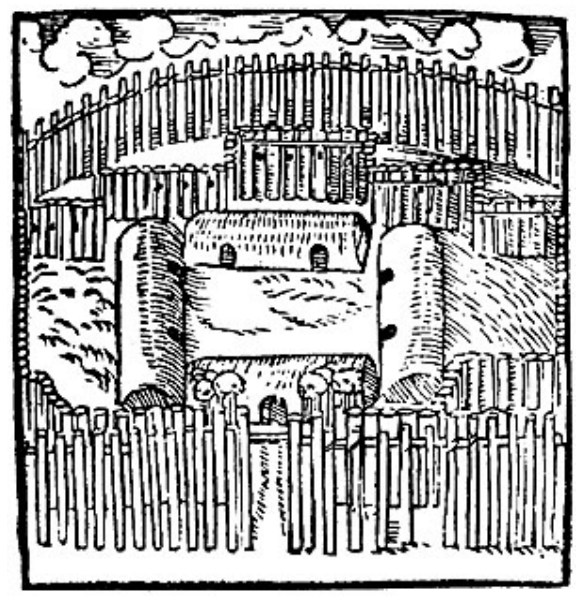

Fig. 2.02. Reprodução da llustração de Hans Standen mostrando paliçadas em torno do agrupamento indígena Tupinambá de 1557.

Outra referência a algum desenho das habitações indígenas está nas edições de Viagem à Terra do Brasil, de Paul Gaffarel, editada em português e em francês ${ }^{2}$. As ilustrações desta publicação foram retiradas da obra Americae Tertia Pars, escrita por Theodor Debry, e mostram cenas do cotidiano, de guerra, de canibalismo e, ao mesmo tempo, imagens muito simplificadas das construções que condizem com os relatos de Pero Vaz de Caminha, conforme se observa na figura 2.02a.

\footnotetext{
${ }^{2}$ A obra de Gaffarel de 1878, publicada em Português e Francês é mencionada por diversos autores e tem notas de Sérgio Milliet.
} 


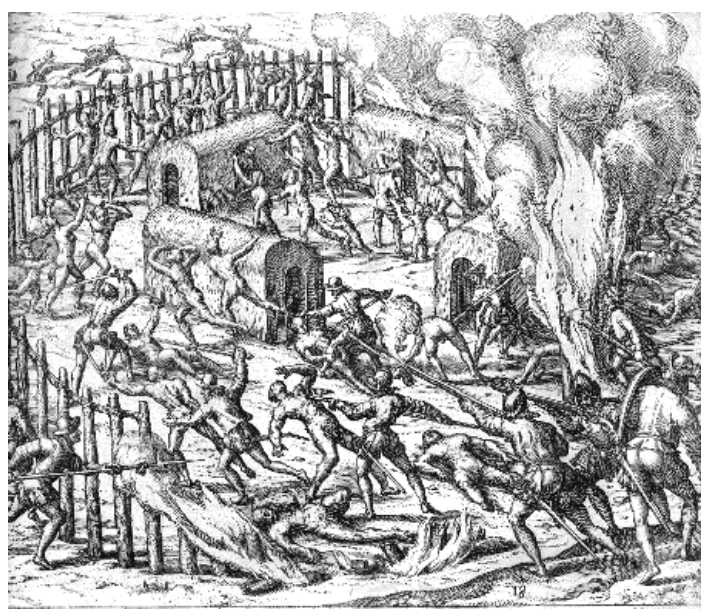

Fig. 2.02a. Entre as cenas de luta e canibalismo indígena podem ser vistas novamente no interior da paliçada algumas habitações longas e muito simplificadas.

As publicações mais recentes analisadas, escritas por MELATTI (1972), por SÁ (1982-1994), assim como por CAIUBY NOVAES (1983) e organizadas por FENELON E BOTELHO (1986) para o Volume 2 de Suma Etnológica Brasileira, dizem respeito essencialmente a uma gama de habitações mas, entre elas, não há estudos relativos às moradias dos índios do Nordeste.

De forma geral, tais obras comentam a utilização de materiais como a madeira, os vários tipos de folhas e troncos de palmeiras e outras folhagens. Sobre as formas de construir apontam que variam desde as circulares, ou elípticas, assim como retangulares.

Em 1980, Berta Ribeiro atribuiu, em sua Tese de Doutoramento, o título de "Civilização de Palha" a um grande grupo de etnias indígenas, dadas as características essenciais de sua tecnologia cesteira, tanto no que diz respeito à arte quanto no que diz respeito às construções. Junto às fig. 2.03, 2.04, 2.05a e 2.05b e 2.06 podem ser observados alguns dos tipos de habitações descritas pelos autores anteriormente abordados. 


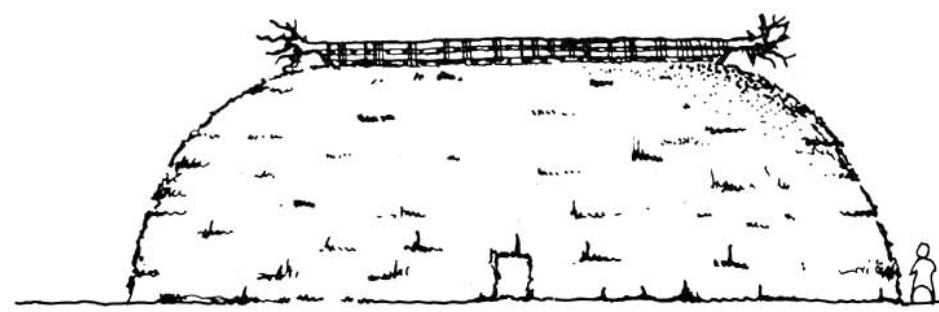

Fachada frontal (principal). Croqui na escala 1:200.

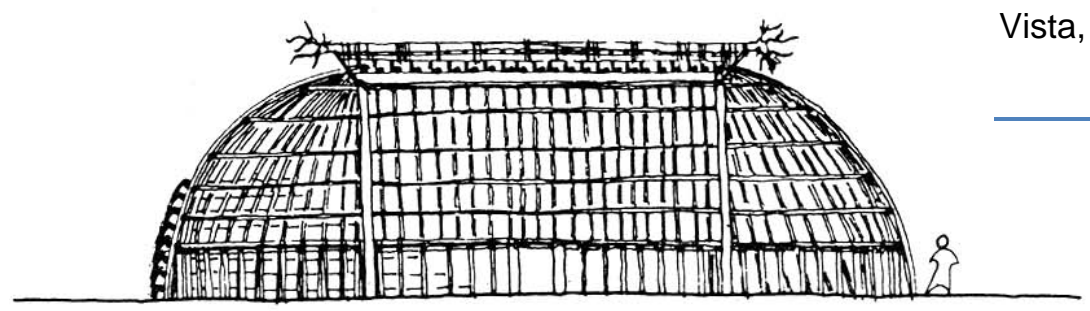

Corte longitudinal. Croqui na escala 1:200.

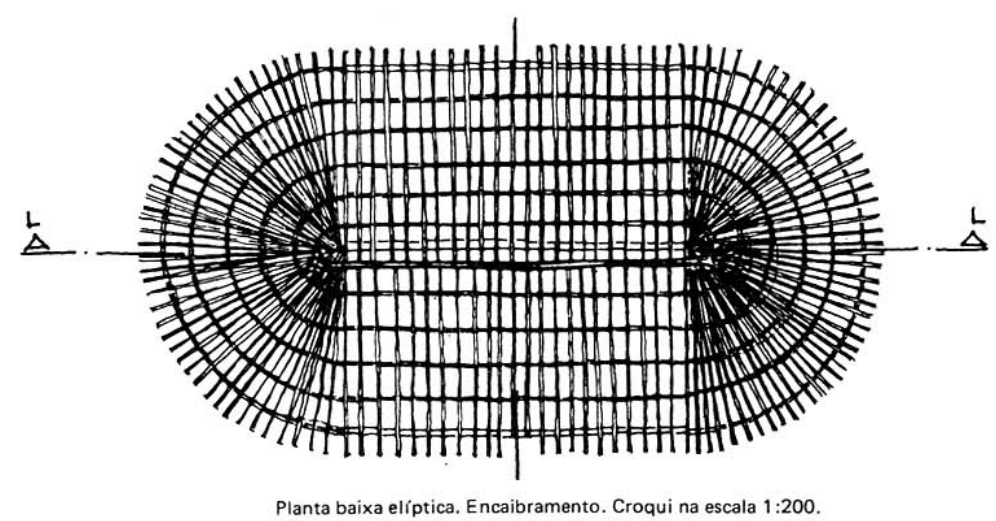

Planta baixa elíptica. Encaibramento. Croqui na escala 1:200.

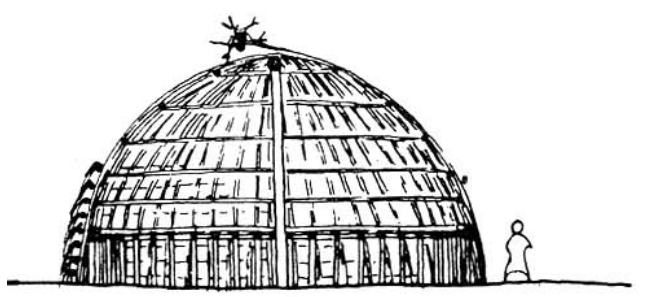

Corte transversal. Croqui na escala 1:200.

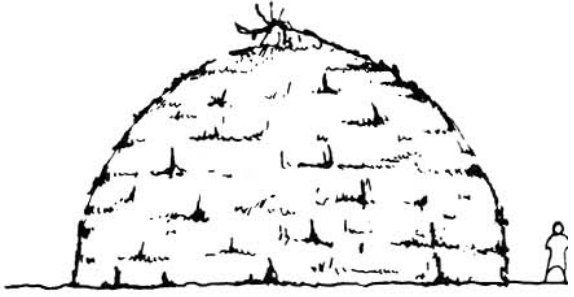

Fachada lateral: Croqui na escala 1:200. 


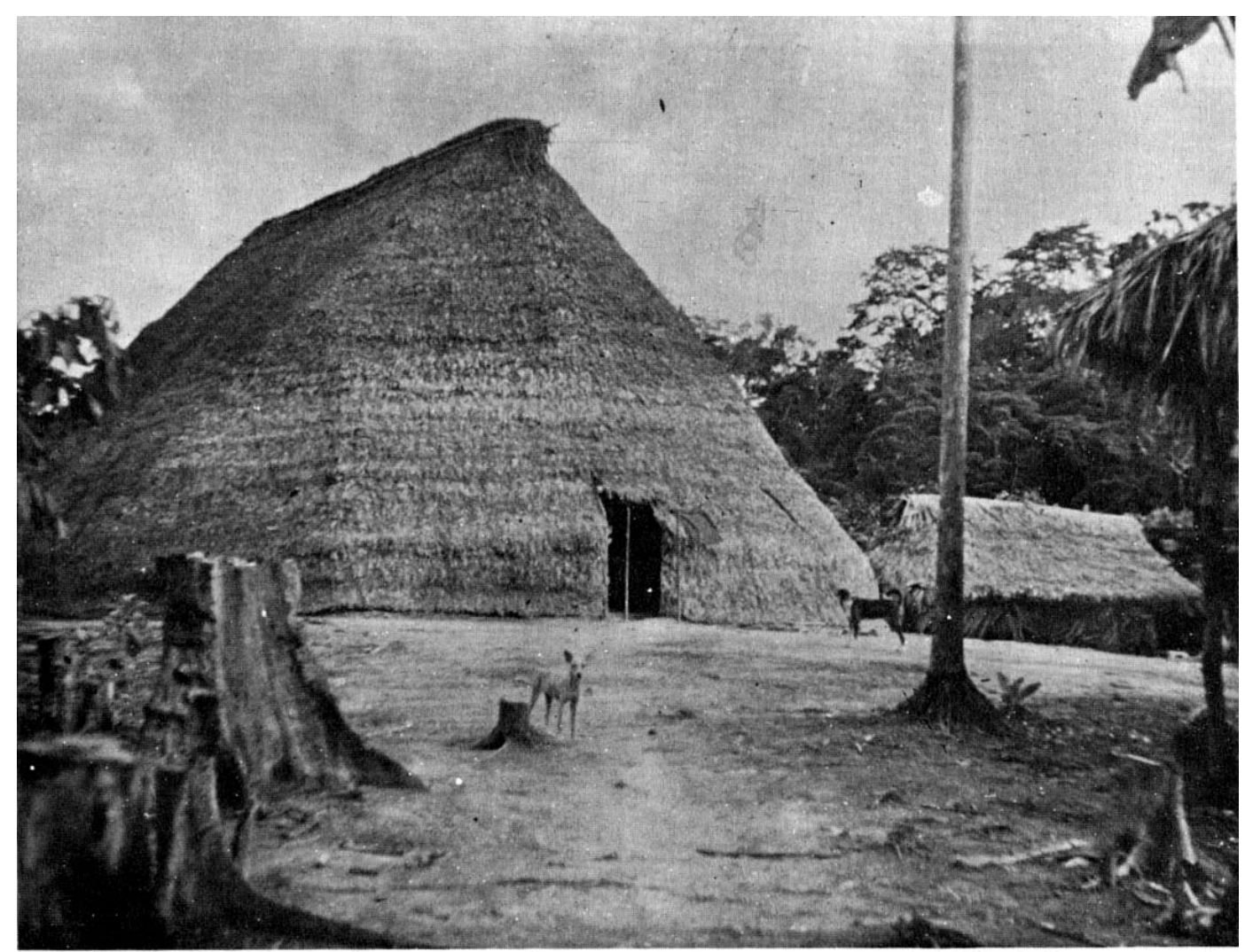
Maloca Marúbo em afluente das cabeceiras do Curuçá (Amazonas).
Foto de D. M. Melatti,

Fig. 2.04. Variação do modelo anterior nas malocas dos índios Marúbo.

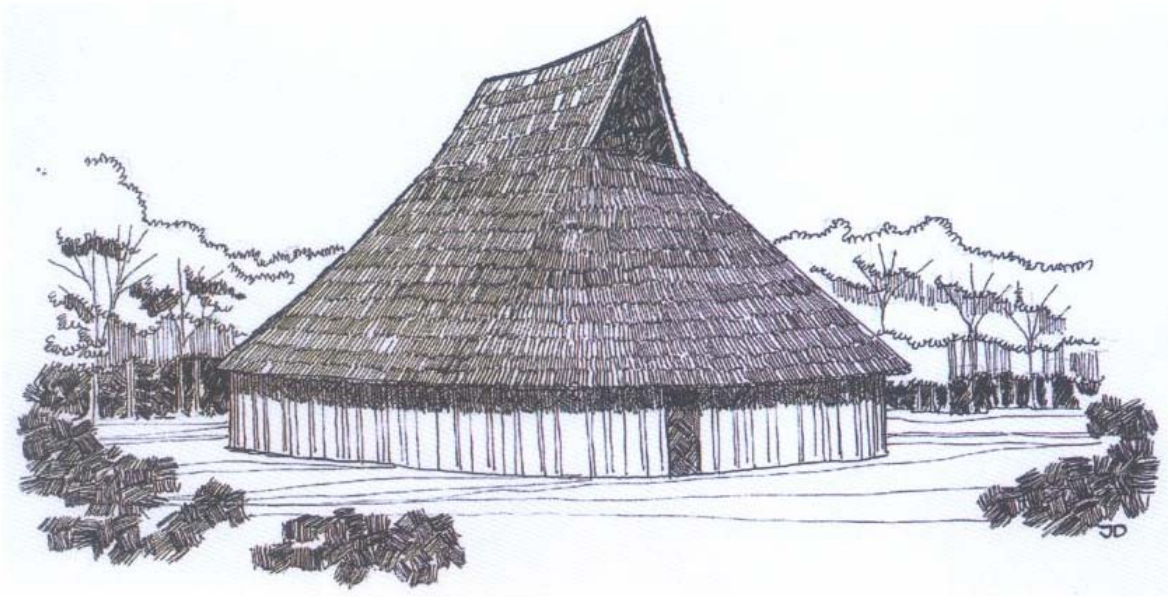

Fig. 2.05a. As malocas da aldeia Makuna foram registradas por Koch-Grünberg como uma variação das casas circulares, com cobertura cônica e paredes de taipa. 

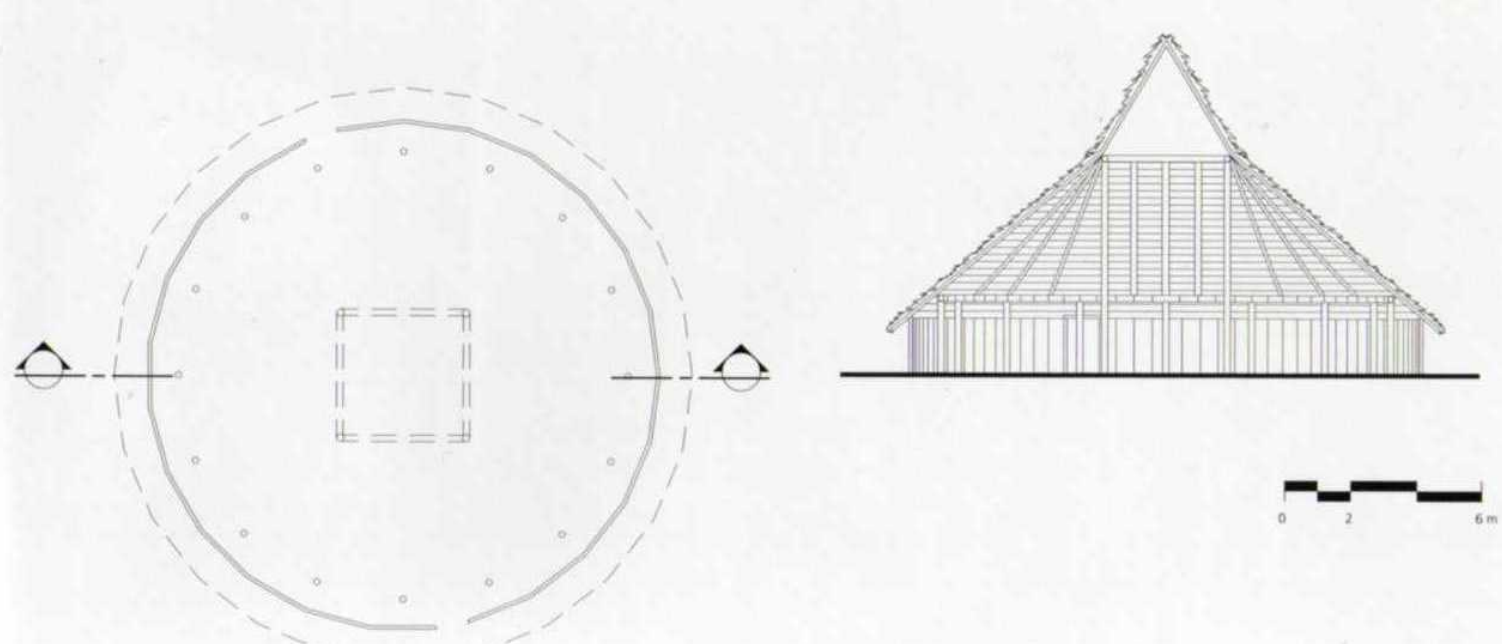

Fig. 2.05b. As malocas da aldeia Makuna em planta e corte.

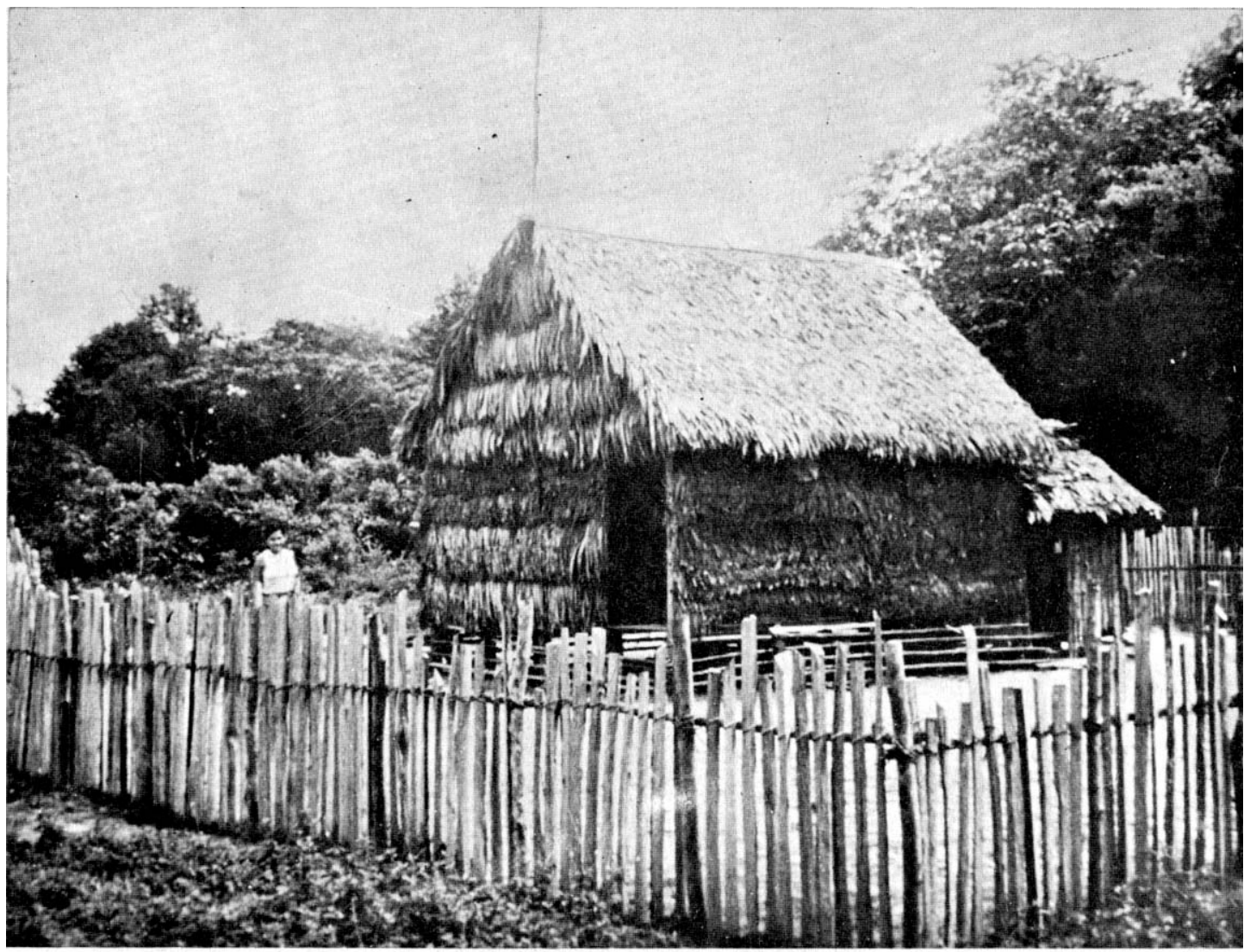

Casa Poyanáwa (Acre). Foto de D. M. Melatti, 1977.

Fig. 2.06. Outra variação de habitação indígena pode ser observada na casa dos Poyanáwa do Acre.

No entanto, em nenhuma das publicações analisadas foi encontrada uma pesquisa consolidada que catalogasse as mais variadas formas de construção e apropriação 
dos materiais de acordo com a etnia ou agrupamento indígena, considerando seus valores históricos, político-sociais, inter-étnicos, antropológicos.

Nas palavras de MURA(2006) "para se compreender o uso que os índios fazem das unidades habitacionais não é oportuno focalizar sua originalidade (no sentido de origem), mas a natureza modular da composição arquitetônica e a sua dinâmica construtiva, em função de técnicas de uso".

Certamente o tema habitação precisa ser revisitado e estudado sob o olhar da história da técnica, que, no entanto, não é o tema dessa pesquisa.

\subsection{Os Índios do Nordeste}

Conforme aponta ARRUTI (2006), "a região Nordeste concentrou as primeiras e maiores atenções relativas aos processos de etnogêneses ${ }^{3}$ ou de formação étnica dos povos indígenas. Não apenas por ser a região de colonização mais antiga e por ter tido todos os seus aldeamentos indígenas oficialmente extintos em um período de menos de 10 anos, entre as décadas de 1860 e 70, mas também porque foi nela que se registraram os primeiros grupos de caboclos reivindicando serem reconhecidos como indígenas. Tais reivindicações se iniciaram nos anos de 1920, prolongando-se por duas décadas, quando foram interrompidas por um longo período, até serem retomadas nos anos 70". Segundo o mesmo autor, no século

\footnotetext{
${ }^{3}$ Conforme Holanda(1992 )e Larousse Cultural(1998). (Do grego ethnos,raça, povo + gênese : do grego génesis, pelo latim genese) ciência que trata da origem dos povos, aspectos ligados a geração, formação, constituição de um povo. Porém, OLIVEIRA (1997), comenta em dois momentos que "é por isso que o fato social que nos últimos vinte anos vem se impondo como característico do lado indígena do Nordeste é o processo denominado etnogênese, abrangendo tanto a emergência de novas identidades como a reinvenção de etnias já conhecidas. Como apontei naquela ocasião (OLIVEIRA,1994), é isso que pode ser tomado como base para distinguir os povos e as culturas indígenas do Nordeste daqueles da Amazônia.
} 
XVIII a região contava com mais de 60 aldeamentos ocupados por cerca de 27 nações indígenas, que foram por decreto extintos antes do ano de 1880.

No entanto, em meados da década de 20, o órgão indigenista oficial passou a atuar no Nordeste. O objetivo era somente o reconhecimento dos índios Carnijó de Águas Bellas, rebatizados como Fulni-ô. Porém, um número crescente de comunidades descendentes de antigas populações aldeadas passou a apresentar suas próprias demandas pelo reconhecimento oficial como indígenas. Ainda de acordo com o mesmo autor, "a principal característica do denominado como primeiro ciclo de etnogêneses (ocorrido desde a década de 1920 até 1940) está em este ter se configurado com base em uma rede de relações previamente existente entre os grupos de "caboclos", tramada com base no calendário de festas religiosas e rituais indígenas que têm como eixo o rio São Francisco e como precedente as viagens entre os antigos aldeamentos. Foi com base nesta rede que os agentes externos, sucessivamente, da Igreja, da Academia e do Estado, entraram em contato com tais grupos. Primeiro, foi por meio de suas visitas aos Fulni-ô (AL), realizadas a convite do Pe.Damaso, que o antropólogo Carlos Estevão entrou em contato com os Pankararu (PE) e os Xucuru-Kariri (AL)".

Ainda que os índios do Nordeste tenham sido aqueles que, em primeiro lugar, tiveram contato com os colonizadores, segundo OLIVEIRA (2004), "ao final do século XIX já não se falava em povos e culturas indígenas do Nordeste, conforme apontou-se a pouco. Salienta-se porém que, desde então, destituídos de seus antigos territórios, não são mais reconhecidos como coletividades, mas referidos individualmente como "remanescentes" ou "descendentes"." 
Tanto as autoridades quanto as populações de cada região nordestina, ou mesmo os próprios índios, se auto-denominam como índios misturados ${ }^{4}$.

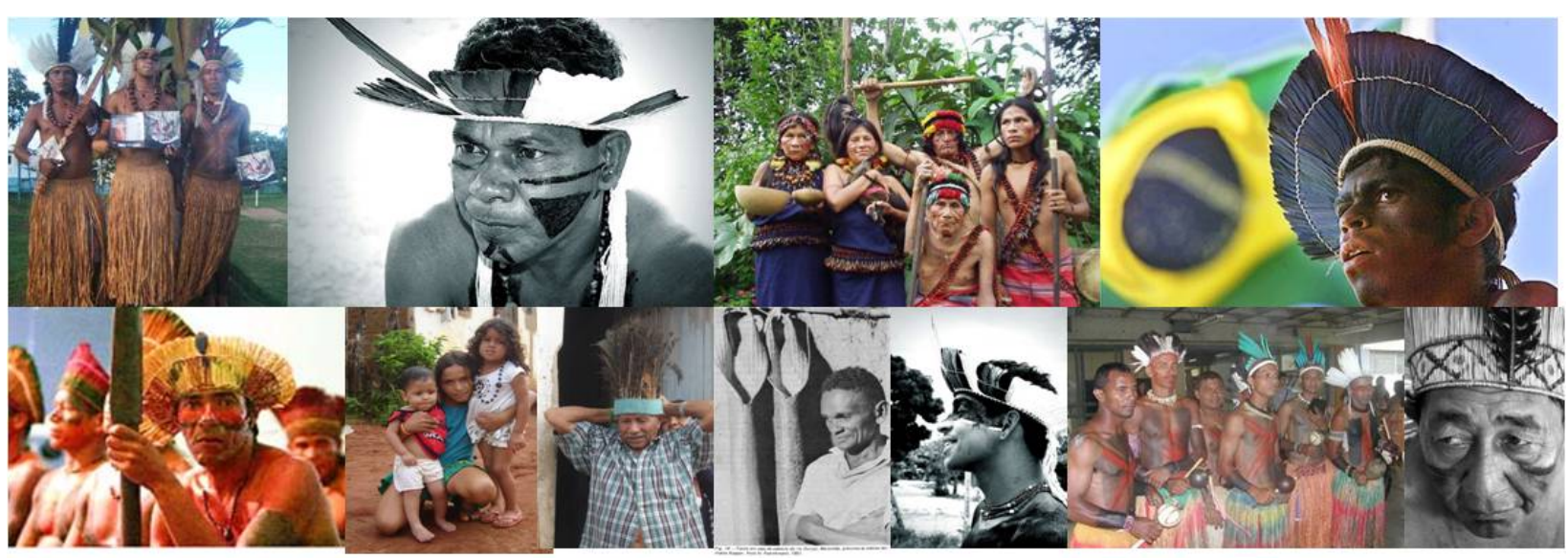

Fig.2.07. Diversas etnias do Nordeste Brasileiro (Potiguaras, Kariri, Xuxuru-Kariri, configurando a categoria de índios 'misturados'.

Nos anos 20 do século XX foi iniciado um movimento de territorialização de terras indígenas no Nordeste, em uma tentativa de regularizar áreas destinadas aos diversos grupos étnicos. A partir de meados dos anos 30 deste mesmo século, teve início a implantação dos Postos Indígenas do Nordeste, com o propósito de atender as populações na região fixadas. Os índios Xucuru-Kariri de Palmeira dos Índios, em Alagoas, tiveram o Posto Indígena criado em 1952 junto da Fazenda Canto.

\footnotetext{
${ }^{4}$ OLIVEIRA (1997) afirma que alguns autores mencionam um estigma, uma caracterização sociológica que poderia aplicar-se a todas aquelas populações: "a partir da segunda metade do século, sobretudo, os índios dos aldeamentos passaram a ser referidos, com crescente freqüência, como índios 'misturados', agregando-se-lhes uma série de atributos negativos que os desqualificam e os opõem aos índios 'puros' do passado, idealizados e apresentados como antepassados míticos" (DANTAS e outros 1992: 451). Tal observação, no entanto, é integrada a uma cadeia puramente cronológica de fatos históricos, sem vir a ser incorporada a um esforço de conceituação. A expressão "índios misturados" - freqüentemente encontrada nos Relatórios de Presidentes de Província e em outros documentos oficiais- merece uma outra ordem de atenção, pois permite explicitar valores, estratégias de ação e expectativas dos múltiplos atores presentes nesse situação interétnica. Em lugar de estabelecer um diálogo com as tentativas de criar instrumentos teóricos para o estudo desse fenômeno - como a noção de 'fricção interétnica (Cardoso de Oliveira, 1964), as críticas às noções de tribalismo e aculturação (Cardoso de Oliveira 1976 e 1968), ou a noção de "situação histórica" (Oliveira, 1988) - , a tendência dos estudos foi restringir-se aos trabalhos sobre a região (tal como a definem) e discutir a "mistura' como uma fabricação ideológica distorcida.
} 


\subsection{Os Xucuru-Kariri em Alagoas}

De onde surgiu este nome? De onde eram originários os Xucuru e os Kariri?

$\mathrm{Na}$ verdade, foi o percurso desses dois grupos étnicos que, em um momento, deu origem a um novo grupo, o povo Xucuru-Kariri. De acordo com CARNEIRO MARTINS (1994: 21),

"Um relato do Vigário de Maia Mello, presbítero secular da Igreja de São Pedro em Roma e sócio-correspondente do Instituto Histórico e Geográfico de Alagoas, tendo sido pároco de Palmeira entre os anos de 1847 e 1899, dá explicações sobre os etnônimos Xucuru e Kariri, relacionando-os também a migrações de índios originários de diferentes localidades: Cita que em 1740 desceram índios da Aldeia de Simbres, do alto Sertão de Pernambuco (local do município de Pesqueira, onde ainda hoje vivem os Xucuru) e vieram outros d'Aldeia do Colégio do Rio São Francisco desta Província (hoje, Porto Real do Colégio, onde localizam-se os Kariri-Xocó), ... aqueles da Tribo Chucuru e estes da Tribu Cariry. Esse autor identifica também diferentes localidades em Palmeira dos Índios, nas quais ...os Chucuru se aldeiaram à margem do pequeno ribeiro, Cafurna, entre terras da fazenda Olhos d'água do Accioly e Serra da Palmeira, fizeram o nome o seu aldeamento ... e os Cariris, também deram o nome do lugar onde se aldearam, Serra do Cariry, onde fizeram uma pequena Igreja, de palha de palmeira (apud ANTUNES,1973:45). O entendimento de que os índios que atualmente residem em Palmeira dos índios migraram de outros lugares e são originários da fusão de dois outros grupos étnicos é, portanto, encontrada em várias fontes".

Os Xucuru-Kariri se estabeleceram no Estado de Alagoas em meados do século XVIII, no município de Palmeira dos Índios, conforme é possível observar na fig.

2.08. Palmeira dos Índios é o segundo maior município daquele estado, cujo nome já indicava a expressiva presença de índios na região.

Conta-se que há muitos anos atrás, havia um índio chamado Tilixi. Este índio era apaixonado por uma índia chamada Tixiliá. No entanto, esse amor era proibido, uma 
vez que a índia estava prometida ao cacique Etafé. Durante uma festa tribal, Tilixi se aproximou de Tixiliá e Ihe deu um beijo. Como castigo, Tilixi foi condenado à morte por inanição. Tixiliá, que estava proibida de ver seu amado, foi ao seu encontro. Esta, ao ser flagrada por Etafé, foi atingida mortalmente por uma flexa. Caindo ferida, Tixiliá morreu junto a Tilixi. Além disso, diz a lenda que no lugar onde morreram nasceu, após um certo tempo, uma formosa palmeira. Surgindo daí o nome da cidade, Palmeira dos Índios.

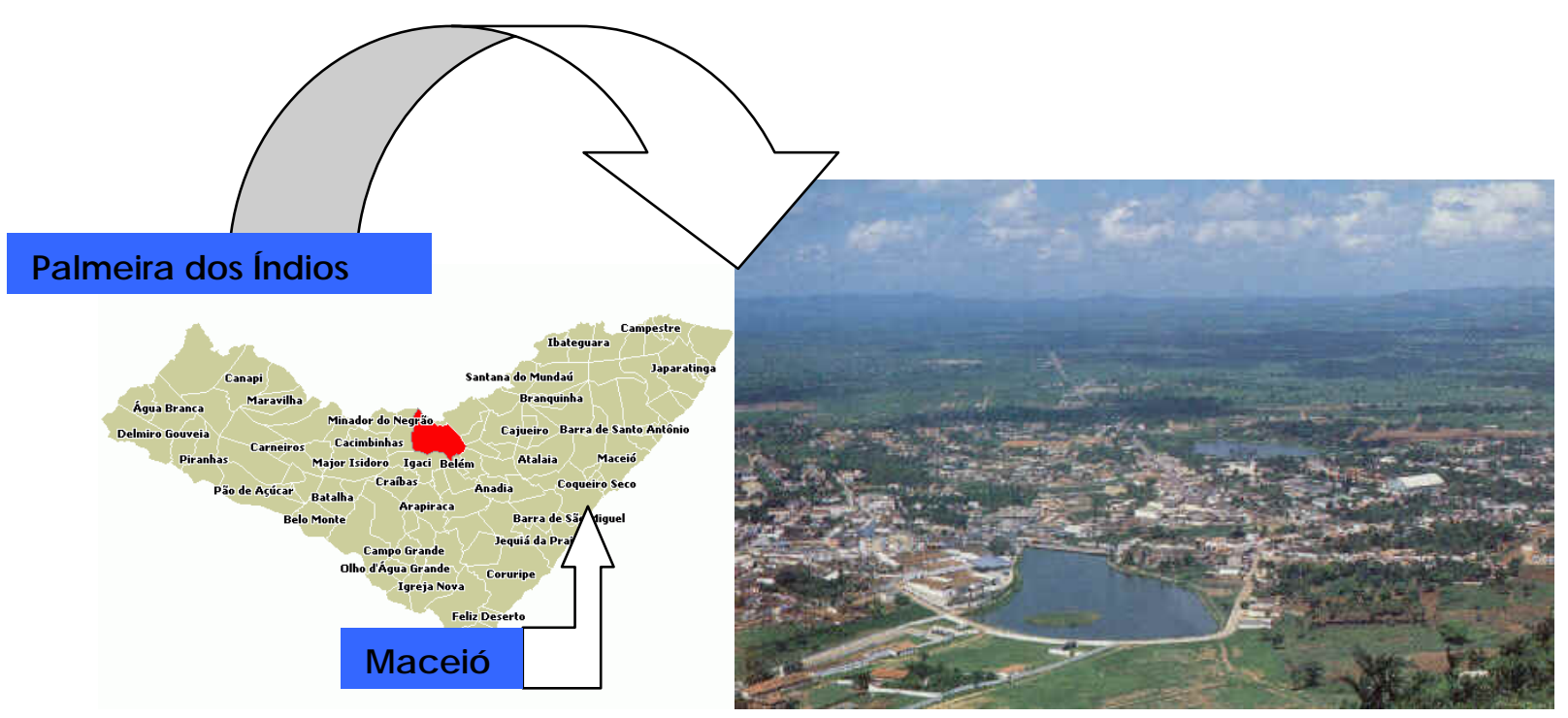

Fig. 2.08. Mapa do Estado de Alagoas destacando em vermelho a localização de Palmeira dos Índios, no agreste alagoano e uma imagem desta cidade com a localização da capital Maceió à beira-mar.

Segundo OLIVEIRA JÚNIOR(1997) ${ }^{5}$, em 1773, "ocorreu a doação de meia légua de terras em quadra ao patrimônio da Capela do Bom Senhor da Boa Morte, constituindo o aldeamento formado nas terras ocupadas pelos índios". De acordo com o mesmo autor, "um século antes, a Coroa Portuguesa produzira uma legislação visando garantir aos índios não apenas o direito sobre as terras ocupadas, como ainda sua (relativa) autonomia no interior das mesmas".

${ }^{5}$ OLIVEIRA JÚNIOR, A.N. Faccionalismo Xukuru-Kariri e a atuação da FUNAI in Anais do Workshop Política Indigenista para o Leste e Nordeste Brasileiro. Carpina-PE: 16 a 21/03/1997, Cópia Impressa. 
Alguns anos mais tarde, já no século XIX, em $1872^{6}$, uma Portaria do Presidente da os índios de Palmeira dos Índios, que atravessavam um período de extrema dificuldade em decorrência da seca de 1870. Porém, o processo de espoliação da gleba indígena contou com uma persistente resistência por parte dos índios.

Como índios considerados guerreiros e lutadores, os Xucuru-Kariri estabeleceram os primeiros confrontos diretos com os pecuaristas locais que durante aquele período procuravam ocupar as terras planas que compõem mais da metade do patrimônio territorial do município de Palmeira dos Índios, tal como se configura na atualidade. As planícies, desde então, eram consideradas as áreas mais férteis do município, daí um dos motivos dos confrontos entre fazendeiros e índios. Infelizmente, paulatina e gradativamente, os Xucuru-Kariri foram pressionados e deslocados para áreas cada vez mais distantes da planície, em direção à serra que margeia o município, ocupando uma área intersticial ${ }^{7}$ serrana, para onde também se dirigiram camponeses mais pobres, provenientes de outras regiões.

De acordo com SANTANA, in TORRES (1973:13), "os Xucurus somente no século atual começaram, de fato a ser estudados, infelizmente quando já se achavam bastante aculturados. Haviam, então, quase perdido totalmente o contato com 0 passado, esquecido suas origens, unidos aos Kariris, em defesa do inimigo comum, o branco. Por isto, sem dúvida os remanescentes indígenas de Palmeira dos Índios,

\footnotetext{
${ }^{6}$ De acordo com ARRUTI, J.M. (2006: 54) ,em decorrência da Lei de Terras de 1850, os estados da federação foram incumbidos de fazer o cadastramento de todas as terras devolutas existentes em seus territórios. Para isso foram instituídas Comissão de Medição e de Demarcação, constituídas por engenheiros e cartógrafos, que içaram com a responsabilidade de avaliar, a partir de um conjunto restrito de itens (a incorporação no mercado de trabalho local, a existência de casamentos com brancos e a profissão da fé cristã), se os aldeados ainda eram indígenas, se já se haviam civilizado. A resposta da Comissão foi, invariavelmente, a constatação da civilidade dos aldeados".

7 A área dos Xucuru-Kariri em Palmeiras dos Índios hoje é de 395,00 hectares, divididos entre a Mata da Cafurna- 118,00 hectares e a Fazenda Canto- 277,00 hectares.

Disponível em < http://www.plantasdonordeste.org> acesso em: 17. nov.2004.
} 
de certo tempo para cá passaram a se declarar Xucurus-Kariris, conforme comprovou Carlos Estevão de Oliveira, em abril de 1937, quando esteve em viagem de estudos, e mais recentemente, em janeiro de 1952, um outro antropólogo, o norte-americano William D. Hohenthal Júnior".

O deslocamento ora apresentado consolidou a situação encontrada pelo antropólogo que, em 1952, comentou: "Os Xucuru-Kariri ocupavam as terras mais pobres e menos desejáveis nas montanhas ${ }^{8 "}$.

Na década de 1940, os índios reiniciaram o processo de lutas pela posse da terra. A forma de organização do grupo, nesse momento, conforme Woortman $(1983)^{9}$, "baseava-se na autonomia da unidade familiar como pilar de uma ética camponesa, que, ao ressaltar o trabalho enquanto elemento de legitimação do acesso a terra, as relações familiares como constituintes do 'capital humano' que possibilita o exercício deste trabalho e a liberdade decorrente desta mesma autonomia, constrói um mundo de relações marcadamente horizontais entre as unidades familiares que o compõem".

A partir de então, os índios pressionaram autoridades e políticos para a regularização de terras em Palmeira dos Índios. Em 1952 a Fazenda Canto recebeu registro com a extensão, de acordo com CARNEIRO (1993), de 372 hectares, 37 ares e 90 centiares. Foi neste mesmo ano que passou a funcionar na Fazendo

\footnotetext{
${ }^{8}$ HOHENTHAL,W. Notes on the Shukuru Indians of Serra Araroba, Pernambuco, Brazil in Revista do Museu Paulista, N.S., Vol. VIII, São Paulo: 1954, pp. 92-116. Esta é uma das observações e aproximações verificadas entre a escolha da Reserva atual, a Fazenda Boa Vista e a última área de terra destinada aos Xucuru-Kariri em Palmeiras dos Índios-AL: na área ocupada em Alagoas havia montanhas, assim como há na área escolhida pelos Xucuru-Kariri em Caldas.

${ }^{9}$ WORTMAN,E. O Sítio Camponês in Anuário Antropológico. Brasília: Imprensa Federal, 1983-1984.
} 
Canto o Posto Indígena, como apontado anteriormente, uma forma de a FUNAI administrar e minimizar conflitos inter-étnicos ${ }^{10}$.

Na década de 1970 habitavam esta fazenda 84 famílias, constituindo uma população indígena de 474 habitantes. Na fig. 2.09 podem ser observadas características atuais e uma antiga das edificações encontradas na Fazenda Canto, em Palmeira dos Índios.

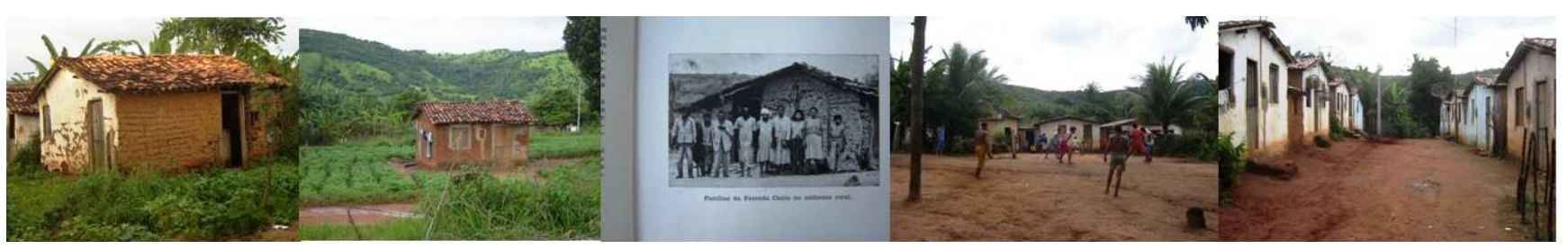

Fig. 2.09. Imagens da organização da Área Indígena da Fazenda Canto.

Em meados da década de 1980, já somavam 106 famílias. Neste período, conflitos violentos ocorreram dentro do próprio grupo residente na Fazenda Canto, ocasionando a morte do Sr. Antônio Celestino, irmão de Miguel e Manoel Celestino, respectivamente cacique e pajé da Fazenda Canto. O grupo liderado por José Sátiro do Nascimento, o cacique "matador" Zezinho, abandonou a Fazenda Canto, dirigindo-se provisoriamente para Ibotirama, na Bahia e daí, em seguida, para Nova Glória, no mesmo estado, onde ganhou, a partir de 1986, a posse de terra da Fazenda Pedrosa, no povoado da Quixaba.

\footnotetext{
${ }^{10}$ Em reportagem especial realizada para a Revista Época de 24/04/2000, o jornalista Ricardo Kotscho em 2000, citando TORRES (1973) comentou que a reunificação da tribo no mesmo espaço físico só se deu em 1952, graças a uma inusitada parceria entre dois latifundiários brancos, Juca Sampaio e Amerencino Costa, e índios carajás e javaés da llha do Bananal, em Tocantins, que vendiam madeira e borracha. Foram eles que doaram os recursos para que os antigos donos da terra comprassem de Manezinho da Luz uma área de 870 hectares (divergindo do número encontrado em registros da FUNAI por CARNEIRO) conhecida como Fazenda Canto, onde chegaram a viver mais de 2 mil Xucurus-Kariris.
} 
Foi o próprio índio rebelado José Sátiro o responsável pela morte que ocasionou a cisão do grupo ${ }^{11}$. A partir do momento em que saiu da Fazenda Canto, entendendo ter recebido a missão paterna de governar um grupo que comungava de suas idéias, o índio José Sátiro do Nascimento se transformou no Cacique Uarkanã de Aruanã.

Algum tempo depois do conflito, em entrevista à Revista Época, afirmou Sátiro: "Tomei a decisão de não deixar mais índio preguiçoso e falso pegar o que era nosso, roubar nossa roça", explica, referindo-se aos rivais da família Celestino. Juntei um grupo de 56 pais de família, fretei um ônibus e fomos procurar a FUNAI em Brasília. ${ }^{12 "}$

\subsection{O percurso do grupo remanejado}

Como anteriormente mencionado, por conta do assassinato de um membro da família Celestino, a FUNAI em 1986 remanejou os Xucuru-Kariri liderados pelo Cacique José Sátiro do Nascimento, Uarkanã de Aruanã, para a Bahia.

O grupo foi primeiramente assentado em Ibotirama ${ }^{13}$, em localidade próxima do Rio São Francisco, permanecendo no local por um curto período. Segundo relatos do Cacique à antropóloga CARNEIRO de AGUIAR (1993 - 90,91): “Explicou que não

\footnotetext{
${ }^{11}$ De acordo com o depoimento do próprio Cacique Zezinho, o "índio rebelado", os conflitos dentro da Fazenda Canto tomaram tal proporção em decorrência de diversas atitudes da família Celestino, antipatizada por muitos naquele local. Conforme o mesmo índio, o fato que de certa forma confirma a conduta dessa família é que hoje não mais residem na Fazenda Canto.

${ }^{12}$ Esta declaração foi publicada em matéria intitulada "A Saga dos Sátiro Xukuru. Alegrias e tristezas da família do primeiro jogador indígena a vestir a camisa de um grande time e da seleção brasileira, de autoria de Ricardo Kotscho, repórter da Revista Época no 101 de 24 de fevereiro de 2000, disponível em http://epoca.globo.com/edic/20000424/especial3a.htm, acessado em 31 de janeiro de 2007.

${ }^{13} \mathrm{O}$ cacique José Sátiro informou também em junho de 2008 que, na verdade, os índios não foram assentados em Ibotirama, mas sim em uma localidade, dentro de uma fazenda próxima à Muquém do São Francisco, município que faz divisa com Ibotirama. Ainda que se buscasse tanto na FUNAI quanto em outros órgãos informações sobre esse período, não foi possível confirmar detalhes desse período.
} 
ficaram em Ibotirama porque em primeiro lugar, não tinha sido uma área que o "grupo" escolheu. Em segundo lugar, devido a conflitos entre fazendeiros que disputavam gleba de terra dentro da área adquirida pela FUNAI. Devido àqueles conflitos entre fazendeiros, insatisfações do grupo com relação à distância dos centros urbanos e constantes ameaças de cheias ocasionadas pela instabilidade do rio São Francisco, o Cacique "Zezinho" (Sátiro) deslocou-se para Brasília, onde permaneceu 120 dias, tentando resolver sobre a aquisição de uma nova área para reassentamento do grupo".Como pode se observar na fig.2.10.1, Ibotirama é uma cidade baiana localizada às margens do Rio São Francisco, no vale deste rio, na micro-região da Barra, distante cerca de $650 \mathrm{~km}$ de Salvador.

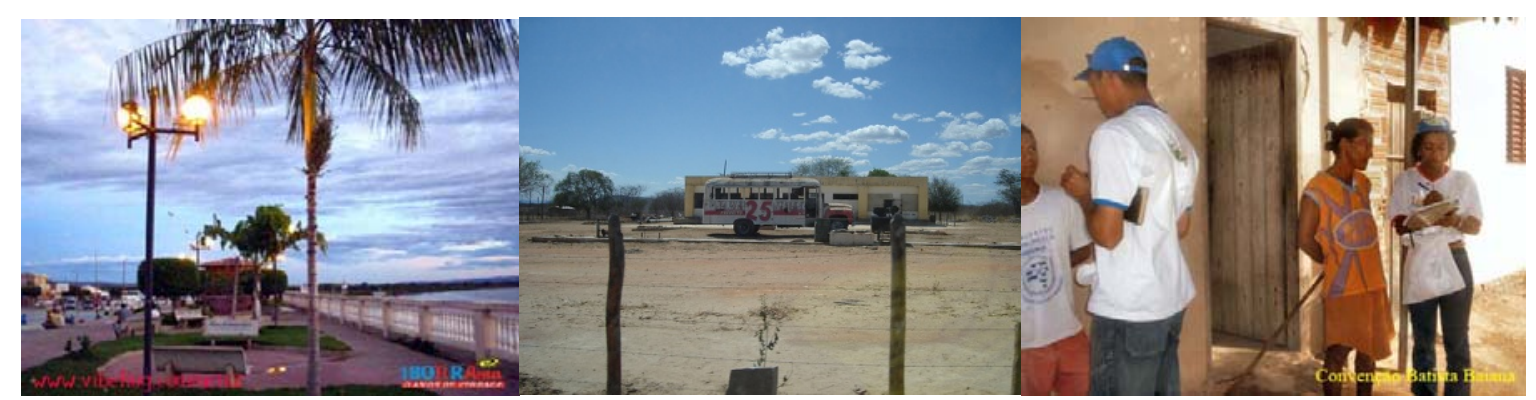

Fig. 2.10.1. Imagens de Ibotirama, primeiro município para onde os Xucuru-Kariri foram remanejados.

No mesmo trabalho a autora menciona que o grupo permaneceu em Quixaba, na Fazenda Pedrosa ${ }^{14}$, na região de Paulo Afonso, no mesmo estado, por um período relativamente extenso, cerca de 18 anos, onde, apesar de conflitos ocasionais, estavam adaptados. Receberam através de influências do CIMI e da Diocese de Paulo Afonso, uma verba de 8 mil dólares doada por sacerdotes italianos que foi destinada à construção de moradias.

\footnotetext{
14 A origem da terra indígena Quixaba remonta aos conflitos havidos entre facções da comunidade da terra indígena Fazenda Canto/AL. A FUNAI, buscando solucionar o impasse, adquiriu em 1986, para assentamento dos índios Xucuru-Kariri, provenientes da TI Fazenda Canto, a propriedade denominada Fazenda Pedrosa, com superfície de 18 ha. Hoje a terra que os índios dispõem é insuficiente para a população ali residente, que se mobiliza para que novas glebas sejam adquiridas para incorporar à terra indígena.
} 
Na fig.2.10.2 pode se observar, primeiramente, a imagem dos índios Xucuru-Kariri diante de uma barraca de lona, primeiro abrigo dos mesmos quando foram afixados na Fazenda Pedrosa. Segundo relatos da índia Tãhira , esposa da Cacique Zezinho,

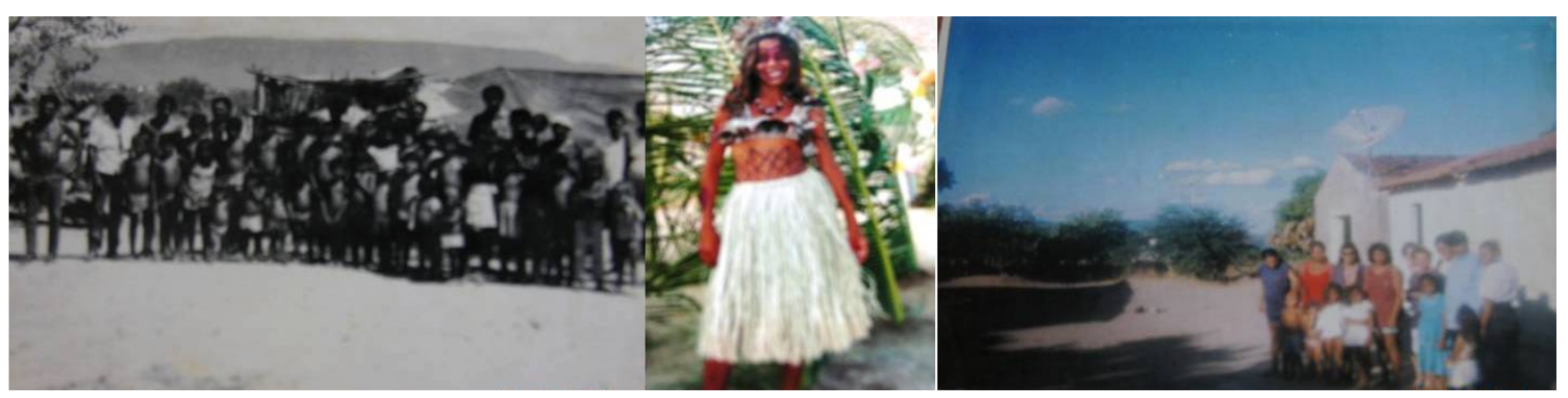

Fig. 2.10.2. Momentos da ocupação Xucuru-Kariri na Fazenda Pedrosa, Quixaba, Nova Glória-BA.

este foi um período muito difícil para os índios por causa do calor intenso e da seca.Na mesma figura observa-se uma garota índia preparada para um Toré e, por último, os índios Xucuru diante da casa de alvenaria do Cacique Zezinho, casa que a família Sátiro do Nascimento habitou até sua saída da Quixaba.

Depois de longos períodos de estiagens e problemas com posseiros na região, procuraram a FUNAI solicitando um novo abrigo ${ }^{15}$. Após insistentes negociações com a FUNAI ${ }^{16}$ acabaram, então, remanejados para o município de São Gotardo, no Estado de Minas Gerais, afixados junto ao distrito da Guarda dos Ferreiros, durante três anos.

\footnotetext{
${ }^{15}$ Apenas uma parte do grupo, a partir de então seguiu os passos do Cacique José Sátiro do Nascimento. Até a mãe e irmãs do Cacique continuam residindo na Fazenda Pedrosa. Vários membros do grupo de Sátiro já foram até Caldas e retornaram à esta Fazenda. Conforme entrevistas e depoimentos realizados durante a pesquisa, (Parisi: 2003, 2006 e 2008), o problema de Caldas é o frio além das ladeiras da Fazenda Agropecuária Boa Vista e a inexistência de água em abundância como ocorre na Bahia dentro da própria área da Fazenda. Como o povoado da Quixaba está às margens de uma área de três barragens do Rio São Francisco, ainda que haja extensos períodos de seca, na propriedade sempre permanece um fio d'água onde os índios podem pescar e eventualmente nadar.

${ }^{16}$ Alia-se ao fato de confrontos internos a perseguição policial que a famíla Sátiro do Nascimento começou a sofrer em decorrência de Jânio, o filho mais velho do Cacique, ter sido acusado da morte de um jovem. ( fato não confirmado pela família Sátiro do Nascimento)
} 
Neste período, segundo relatos do Cacique Uarkanã, os índios passaram por muitas dificuldades e enfrentaram diversos problemas como a fixação urbana, a inexistência de terras próprias para o cultivo, as dificuldades relativas ao trabalho que os auxiliasse a garantir a subsistência. Ainda assim, algumas famílias do grupo acabaram fixando residência neste município, em virtude da atividade agrícola do

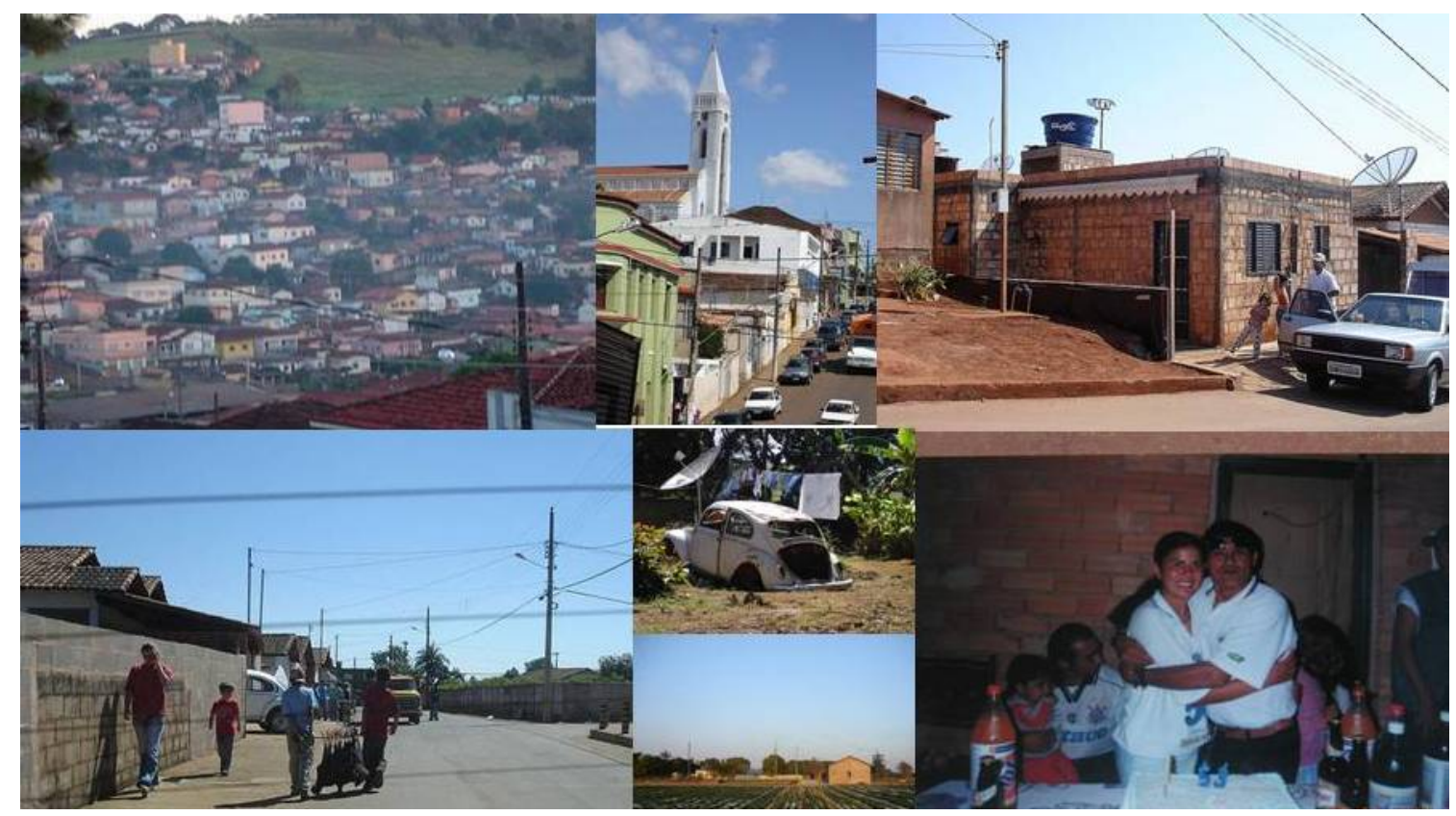

Fig.2.11. Imagens de São Gotardo-MG com destaque para o distrito de Guarda dos Ferreiros. Na última imagem o Cacique Zezinho em sua casa de alvenaria no Distrito da Guarda.

plantio e colheita de cenoura. Na fig 2.11 podem se observar três imagens de São Gotardo e, sucessivamente, quatro imagens do distrito de Guarda dos Ferreiros; com destaque, na última imagem, um aniversário do Cacique Zezinho em sua casa de alvenaria.

De acordo com depoimento do fotógrafo e veterinário Davi Sato, de São Gotardo, que manteve um relacionamento de amizade com os índios Xucuru, em virtude de seu pai possuir um Supermercado em Guarda dos Ferreiros, os índios ocupavam 
uma mesma casa do local. O grupo era constituído de cerca de cinqüenta pessoas. $\mathrm{Na}$ verdade, logo que foram para Guarda dos Ferreiros, os índios moraram primeiramente em uma casa onde hoje funciona um "alojamento" para trabalhadores rurais. Ocupam atualmente a casa dezenove homens. Depois de algum tempo, a FUNAI acabou transferindo os índios para uma outra casa, um pouco mais ampla. As duas casas podem ser observadas na fig.2.11a. A última residência dos Xucuru na 'Guarda', como os habitantes denominam essa localidade, foi vendida e reformada depois que os índios de lá saíram.

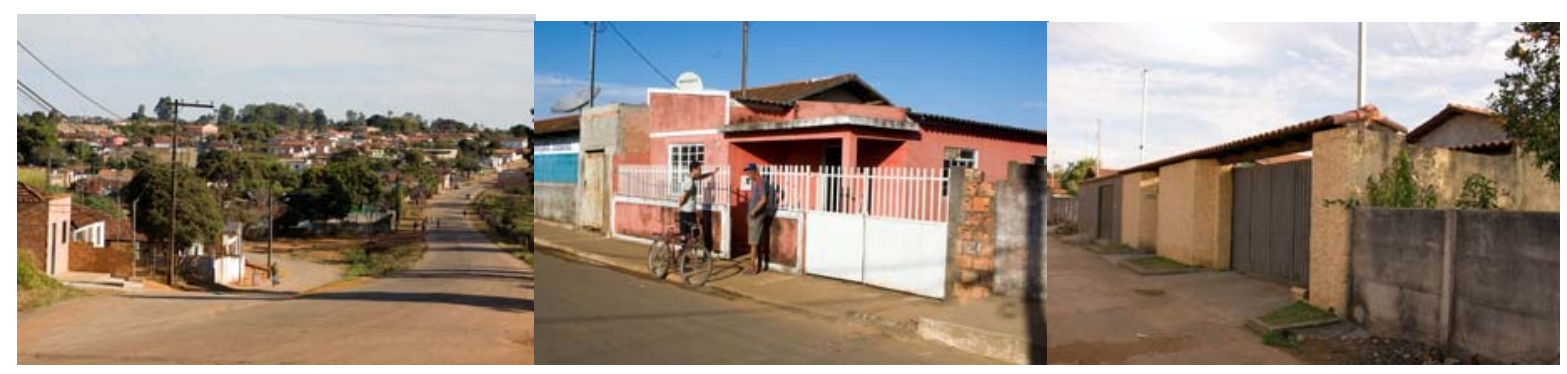

Fig.2.11a. A entrada de Guarda dos Ferreiros, a primeira casa onde os Xucuru-Kariri moraram e a última residência dos índios nesse lugar.

Ainda hoje, membros remanescentes do grupo remanejado continuam morando em Guarda dos Ferreiros em casas de alvenaria e trabalhando em propriedades agrícolas do local, como será possível observar na fig. 2.11b.

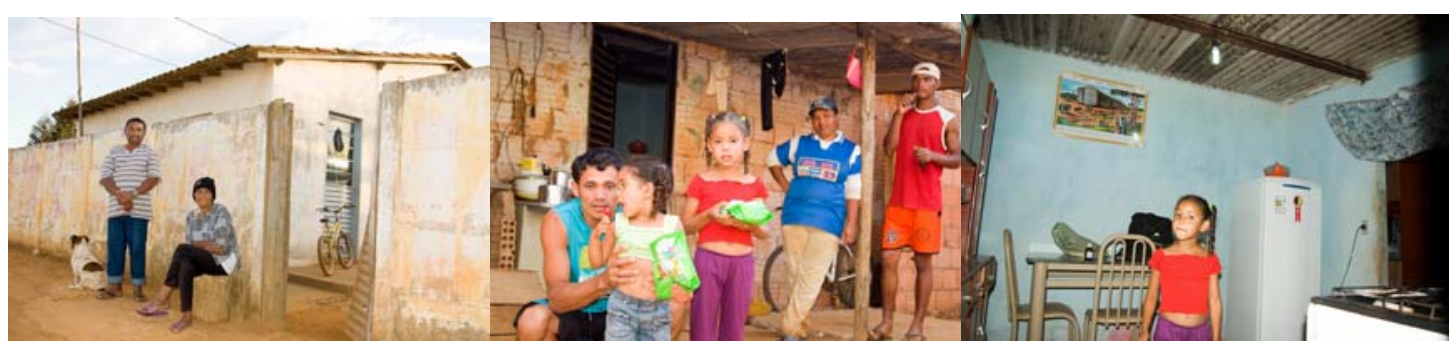

Fig.2.11b. Aspectos internos e externos da casa ocupada por membros do grupo Xucuru-Kariri em Guarda dos Ferreiros, além de imagem da família reunida diante da moradia. 
Entre esses deslocamentos foram mais de $4200 \mathrm{~km}$, aproximadamente 51 horas e 50 minutos de percurso, além de carregarem a angústia e incerteza de que um dia haveria, de fato, uma terra prometida.

De forma sintetizada, o caminho percorrido pelos índios Xucuru-Kariri desde Palmeira dos Índios foi o seguinte:

\begin{tabular}{|c|c|c|c|c|}
\hline $\begin{array}{l}\text { Municípiol } \\
\text { Região de } \\
\text { Origem }\end{array}$ & $\begin{array}{c}\text { Municípiol Região } \\
\text { de Chegada }\end{array}$ & $\begin{array}{l}\text { Distância } \\
\text { percorrida }\end{array}$ & $\begin{array}{l}\mathrm{N}^{\circ} \text { de Horas de } \\
\text { Deslocamento }\end{array}$ & Ano/ Data \\
\hline $\begin{array}{l}\text { Palmeira dos } \\
\text { Índios- AL }\end{array}$ & Ibotirama- BA & 1042 & $\begin{array}{c}13 \text { horas e } 22 \\
\text { minutos }\end{array}$ & 1986 \\
\hline Ibotirama- BA & $\begin{array}{l}\text { Nova Glória- BA. } \\
\text { Faz. Pedrosa, } \\
\text { Povoado da } \\
\text { Quixaba }\end{array}$ & 903 & $\begin{array}{c}11 \text { horas e } 46 \\
\text { minutos }\end{array}$ & 1991 \\
\hline $\begin{array}{l}\text { Nova Glória- BA. } \\
\text { Faz. Pedrosa, } \\
\text { Povoado da } \\
\text { Quixaba }\end{array}$ & $\begin{array}{l}\text { São Gotardo-MG, } \\
\text { Distrito de Guarda } \\
\text { dos Ferreiros }\end{array}$ & 1773 & $\begin{array}{c}20 \text { horas e } 40 \\
\text { minutos }\end{array}$ & 1999 \\
\hline $\begin{array}{l}\text { São Gotardo-MG, } \\
\text { Distrito de Guarda } \\
\text { dos Ferreiros }\end{array}$ & $\begin{array}{c}\text { Caldas- MG, } \\
\text { Fazenda } \\
\text { Agropecuária Boa } \\
\text { Vista }\end{array}$ & 489 & $\begin{array}{c}6 \text { horas e } 2 \\
\text { minutos }\end{array}$ & $\begin{array}{l}2001 \text { até o } \\
\text { período atual }\end{array}$ \\
\hline
\end{tabular}

Quadro 01.Informações sobre o percurso dos Xucuru-Kariri sintetizadas a partir do Google-Earth/ e do Google MapAcesso em: 27.jun.2008.

Através do detalhamento do trajeto, constata-se que os Xucuru-Kariri venceram inúmeras dificuldades geográfico-regionais e culturais até chegarem a Caldas em 
2001. Na fig.2.12 apresenta-se o mapa com os deslocamentos dos Xucuru-Kariri desde sua saída de Palmeira dos Índios.

Segundo relato do Cacique Uarcanã, quando questionado sobre o pior momento de toda a caminhada, o período mais difícil, ainda que curto, foi a fixação na região de Ibotirama, uma vez que o local em que residiram os índios era precário e distante de tudo.

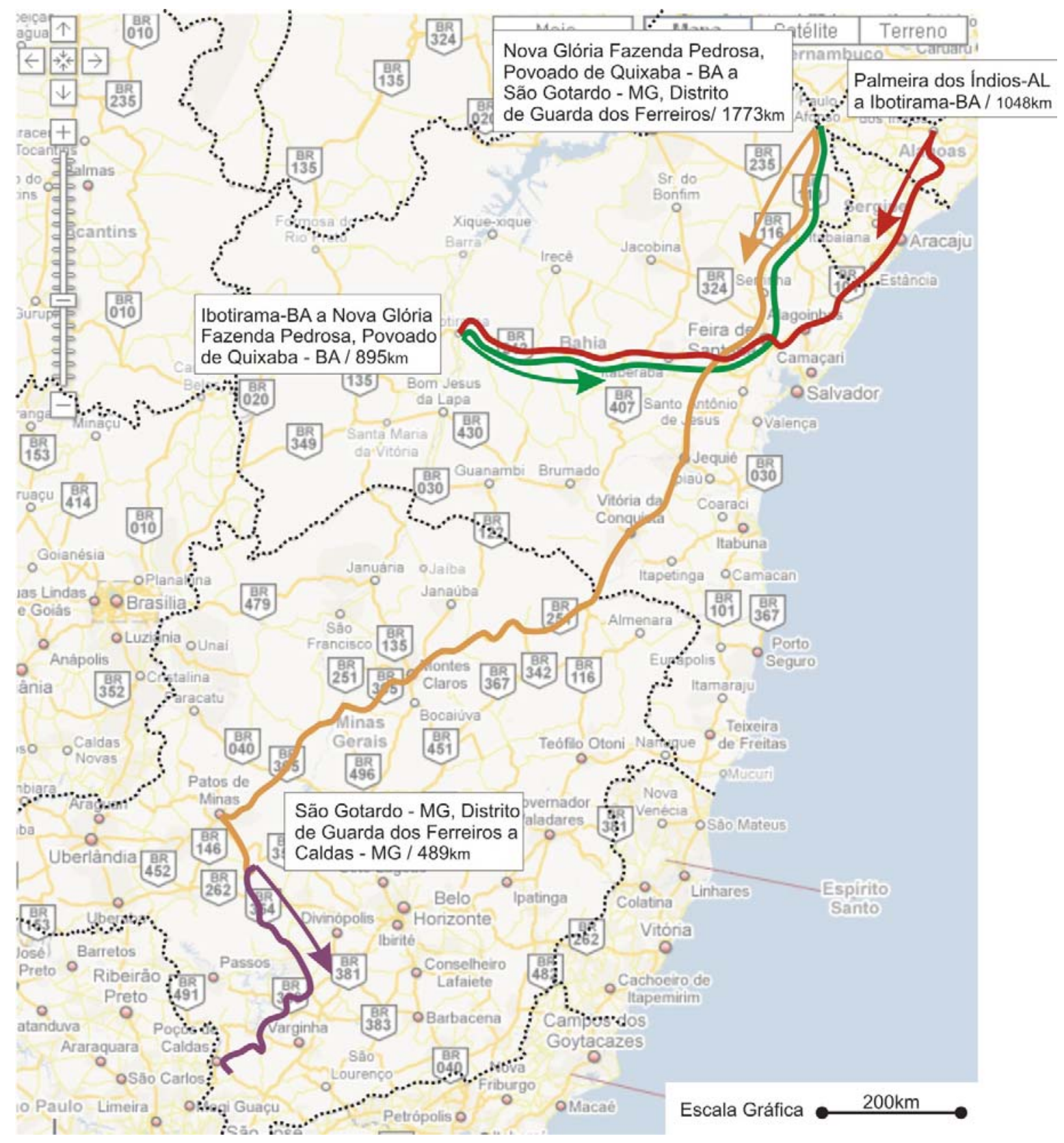

Fig.2.12. Percurso geral dos Xucuru-Kariri remanejados. 
Somente depois das muitas visitas à FUNAI empreendidas pelo cacique e seus representantes escolhidos, foram-lhes apresentadas, finalmente, três opções de escolha de terras pertencentes à União. O cacique Xucuru, acompanhado de alguns outros índios do grupo, visitou essas três propriedades da União, sendo duas delas localizadas na Bahia, próximas aos locais onde anteriormente viveram e uma localizada ao sul de Minas Gerais, no município de Caldas. Esta, finalmente foi a escolhida pelos índios, que alimentavam a esperança de fugirem da seca e, em terras férteis, poderem novamente, viver tempos de fartura e prosperidade.

\subsection{O município de Caldas, local da fixação definitiva dos Xucuru-Kariri}

Os índios Xucuru-Kariri chegaram finalmente em Caldas em maio de 2001.

Caldas é um dos municípios mais antigos de Minas Gerais, que também ficou conhecido por suas águas com propriedades curativas, além de uma expressiva área destinada ao cultivo da batata inglesa e da batata-doce, além da fruticultura, viticultura, produção de milho e feijão. Desde a década de 1930, através da visão empreendedora dos produtores rurais do município e região, instalou-se no município a Fazenda Experimental da EPAMIG, que trabalha com pesquisa e aprimoramento de uvas para o desenvolvimento da vitinicultura. A área rural do município, cerca de 698,52 km2, por conta da altitude, é adequada para a produção das culturas anteriormente especificadas. $\mathrm{Na}$ fig.2.13 observam-se as características do relevo e implantação da cidade de Caldas. 


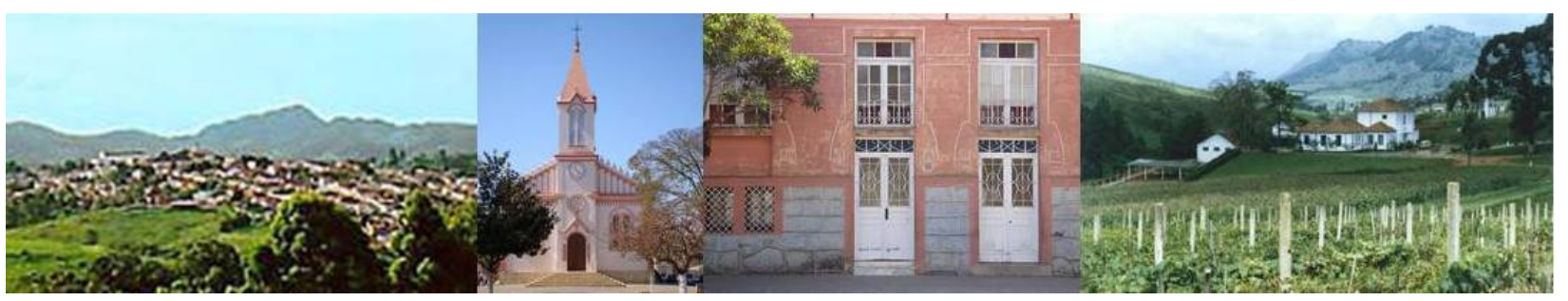

Fig. 2.13. A cidade Caldas, a Igreja Matriz, o casario e a Fazenda Experimental da EPAMIG.

Uma de suas propriedades agrícolas, com cerca de 100 hectares, passou para o domínio da União e pode posteriormente, através de ação da FUNAI, ser doada ao grupo Xucuru-Kariri remanejado, fazendo com que a solicitação do Cacique José Sátiro do Nascimento fosse atendida. A área da Fazenda Agropecuária Boa Vista, atual Reserva Xucuru-Kariri, pode ser observada na fig.2.14. Está localizada próxima da Rodovia BR 459 que liga Poços de Caldas à Pouso Alegre, com acesso cerca de $2 \mathrm{~km}$ após a bifurcação da estrada vicinal que interliga Caldas à São Pedro de Caldas.

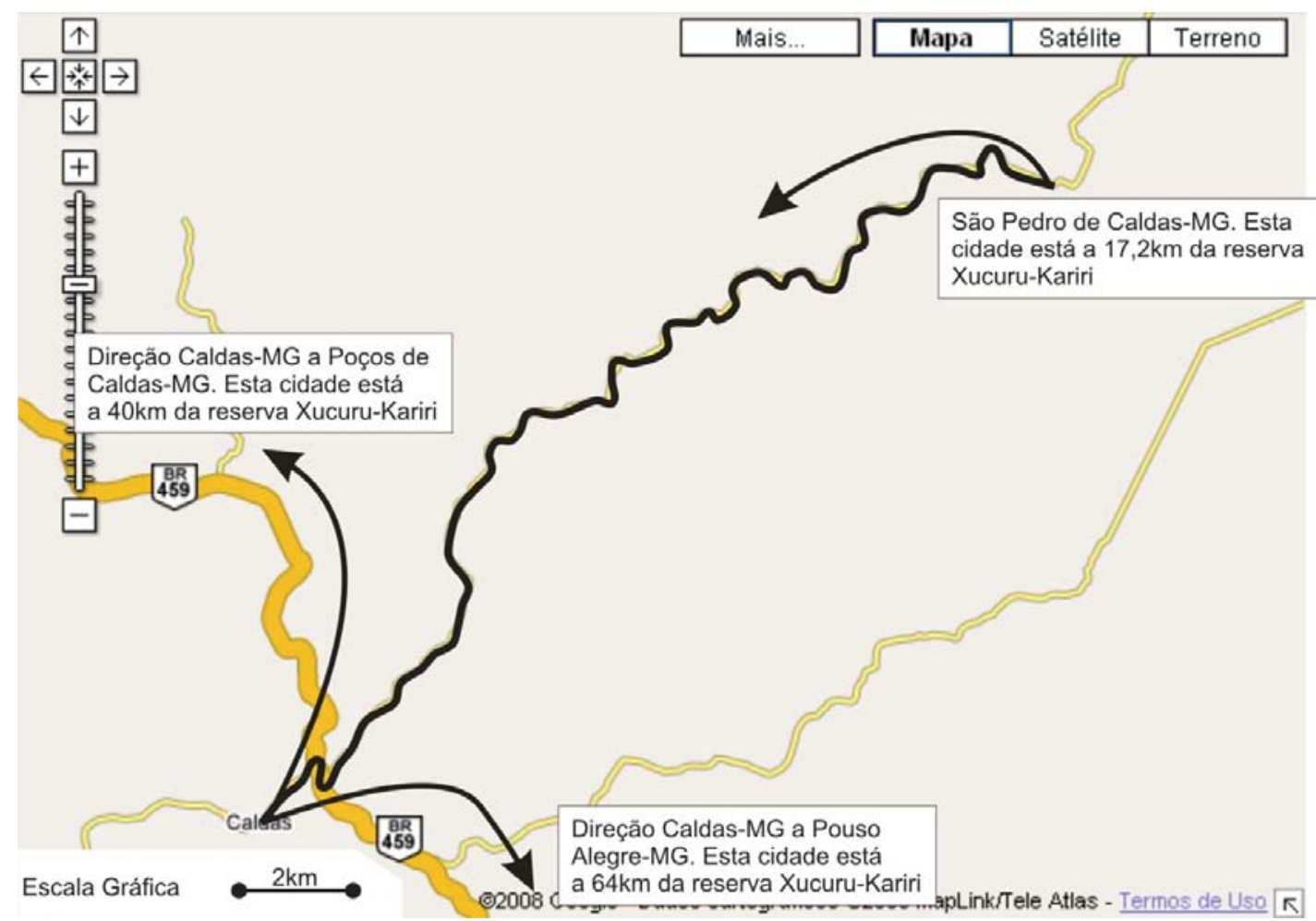

Fig. 2.14. Mapa com a localização da Reserva Xucuru-Kariri 


\subsection{A Reserva Indígena de Caldas em 2001}

Do ponto de vista da caracterização da paisagem, a Reserva de Caldas, que pode ser observada na fig. 2.15, guarda alguma semelhança com a área da Fazenda Canto, em Palmeira dos Índios. Tanto o acesso para a Reserva de Caldas quanto para a fazenda Canto se dão em aclive. As duas propriedades possuem um relevo sinuoso, característico de regiões serranas.

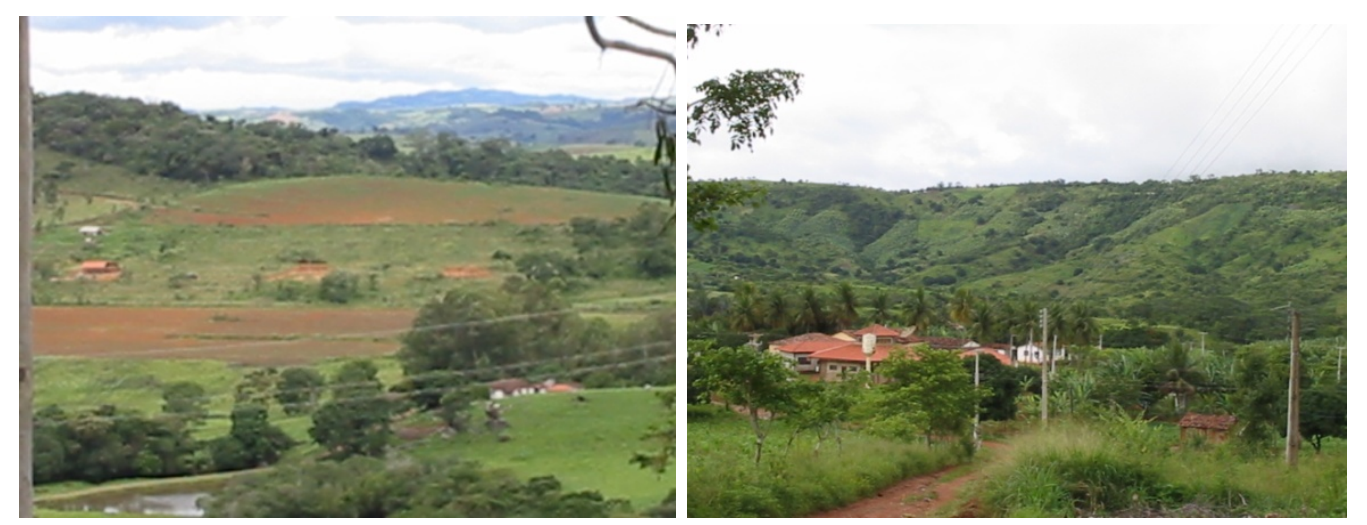

Fig. 2.15. A primeira imagem é da Fazenda Boa Vista, atual Reserva Xucuru-Kariri em Caldas-MG e a segunda é da Fazenda Canto, em Palmeira dos Índios. São duas propriedades localizadas junto de áreas montanhosas que guardam semelhanças visuais.

A área está situada ao sul do Estado de Minas Gerais, como pode se observar na fig. 2.16, na zona rural do município de Caldas. Com seus 100 hectares, a propriedade é constituída de áreas de mata nativa e de reflorestamento, áreas para cultivo e pastagens, além casas e galpões construídos por volta de 1940.

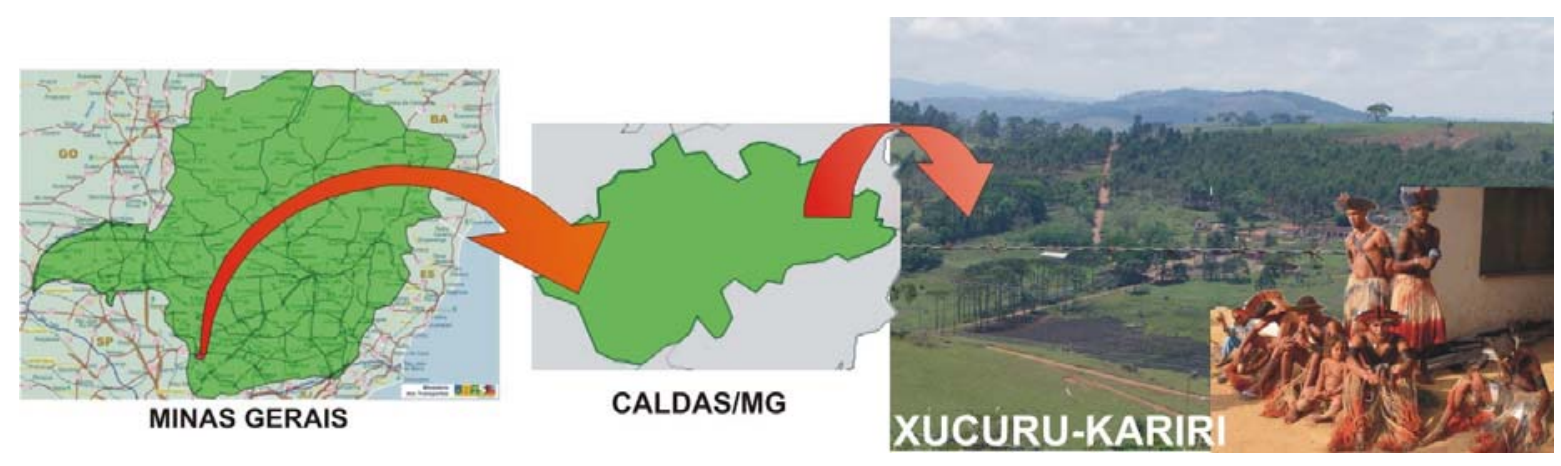

Fig. 2.16. Localização da Reserva Indígena Xucuru-Kariri no município de Caldas e no Estado de Minas Gerais. 
A maior parte das casas da propriedade rural apresentava em 2002 relativas condições de habitabilidade, necessitando de algumas melhorias como reconstituição de revestimento e pintura, colocação de vidros, substituição de telhas quebradas. Na fig.2.17 poderão ser observadas, através das cores diferenciadas, as edificações existentes, aquelas em que os índios empregaram taipa de mão/pau-apique e as edificações em 'novaterra', assim como a única habitação construída com o emprego de blocos de concreto.

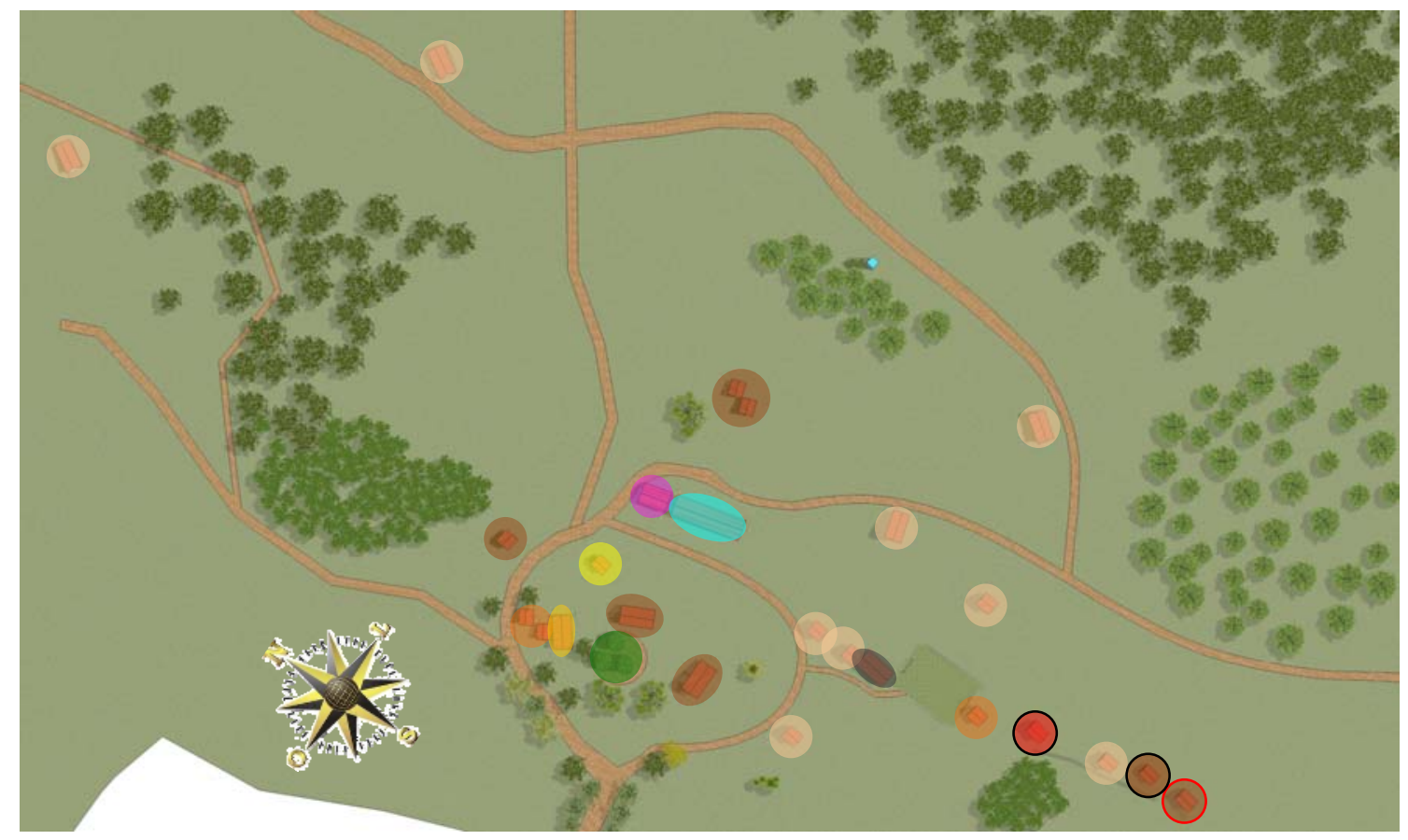

Casa em alvenaria convencional

Casa em alvenaria convencional e ampliação em taipa

Casa em taipa de mão feita pelos Índios

Casa em 'NOVATERRA' (Objeto Análise)

Casa em 'NOVATERRA'

Casa em 'NOVATERRA' e taipa de mão

Casa em alvenaria blocos ('TESTEMUNHO' pesquisa)

Casa em alvenaria tijolos principal (Cacique)

Posto de saúde, construção em alvenaria

Galpão de alvenaria com 2 habitações adaptadas mais escola indígena

Galpão de alvenaria precário adaptado a 2 moradias

Quiosques de recepção parcialmente danificados

Fig. 2.17. Adaptação do mapa e levantamento realizados em 2002 para o período atual, com a implantação de todas as habitações existentes no local. 
As onze famílias dos índios Xucuru, de acordo com a orientação do Cacique Uarkanã e do Cacique Substituto $\mathrm{Jao}^{17}$, foram assentadas nas habitações existentes. Acabaram ainda por adaptar dois precários barracões para habitações de mais quatro famílias, duas em cada um deles, conforme será possível observar através da fig.2.18.
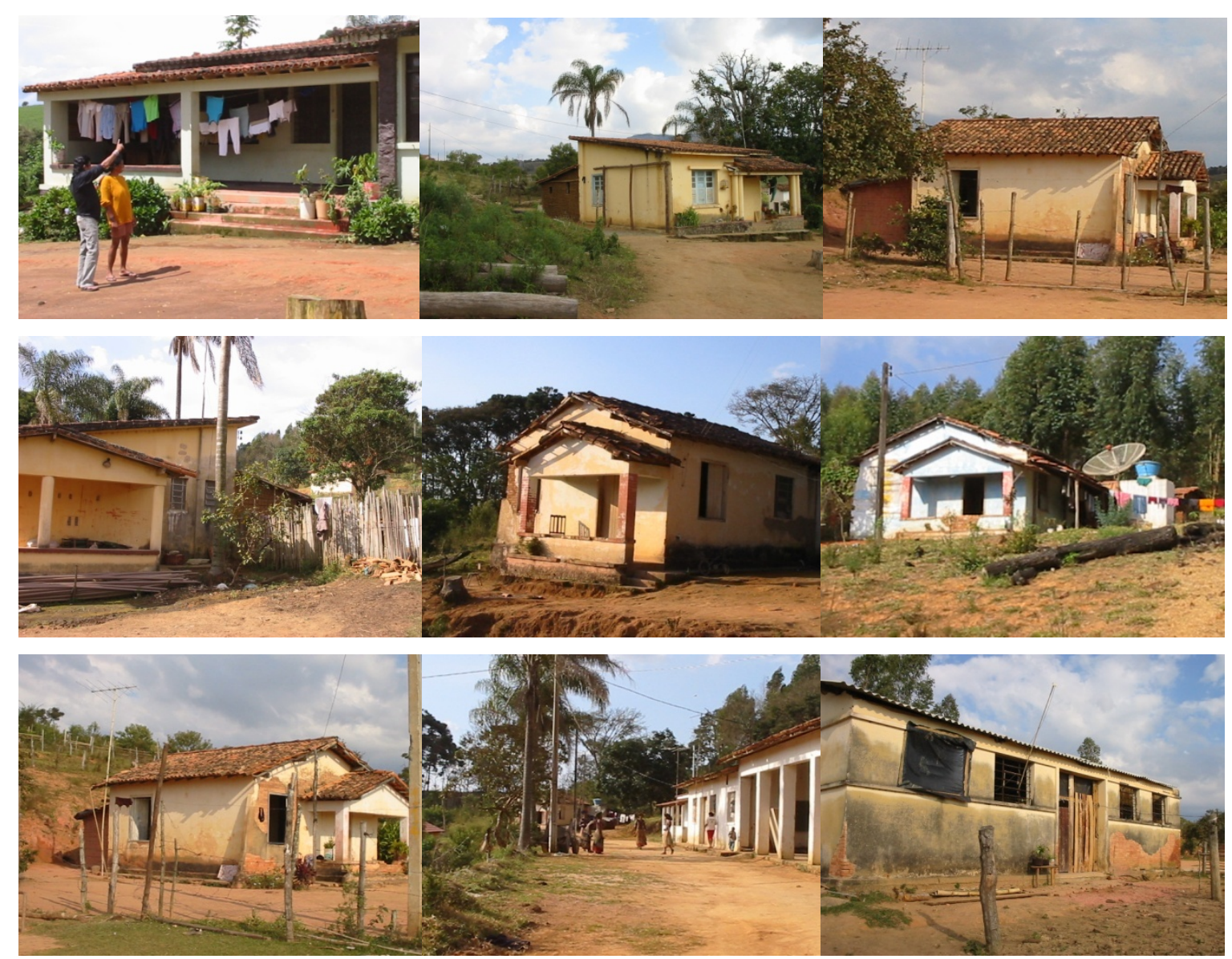

Fig. 2.18. As nove edificações existentes na Fazenda Boa Vista, em Caldas-MG, quando os índios Xucuru em maio de 2001 afixaram-se na propriedade. Fonte: Parisi,R.S.B. Março a Agosto de 2002.

No entanto, conforme o tempo passava, outras famílias Xucuru deixavam São Gotardo-MG, Nova Glória-BA ou Palmeira dos Índios- AL e se dirigiam para Caldas. As informações sobre as boas condições climáticas da Reserva de Caldas, assim como a possibilidade de se resgatarem antigos laços familiares e de amizade,

\footnotetext{
${ }^{17}$ Durante o presente trabalho o Cacique Uarkanã explicou que a escolha de Jao como Cacique Substituto, ou seja, aquele que um dia o irá suceder e que o auxilia a tomar decisões importantes para o grupo, decorre de orientações espirituais e orientações de seu falecido pai.
} 
fomentavam o longo percurso. O número de habitações existentes na Reserva de Caldas se tornara insuficiente para atender a demanda crescente de famílias indígenas que chegavam.

Durante aquele período, foram necessárias e construídas mais duas unidades de habitação com a técnica da taipa de mão ou pau-a-pique, tecnologia que emprega a terra, que os índios conheciam e dominavam desde tempos atrás, quando ainda residiam em Palmeira dos Índios.

As duas moradias construídas em terra na Reserva Indígena, conforme pode se observar na fig. 2.19, guardam de fato, muita semelhança com aquelas encontradas na Fazenda Canto em Palmeira dos Índios quando, durante a pesquisa, houve oportunidade de se conhecer o local e, efetivamente, certificar-se de que os XucuruKariri eram, há muito tempo, hábeis "construtores de terra”.

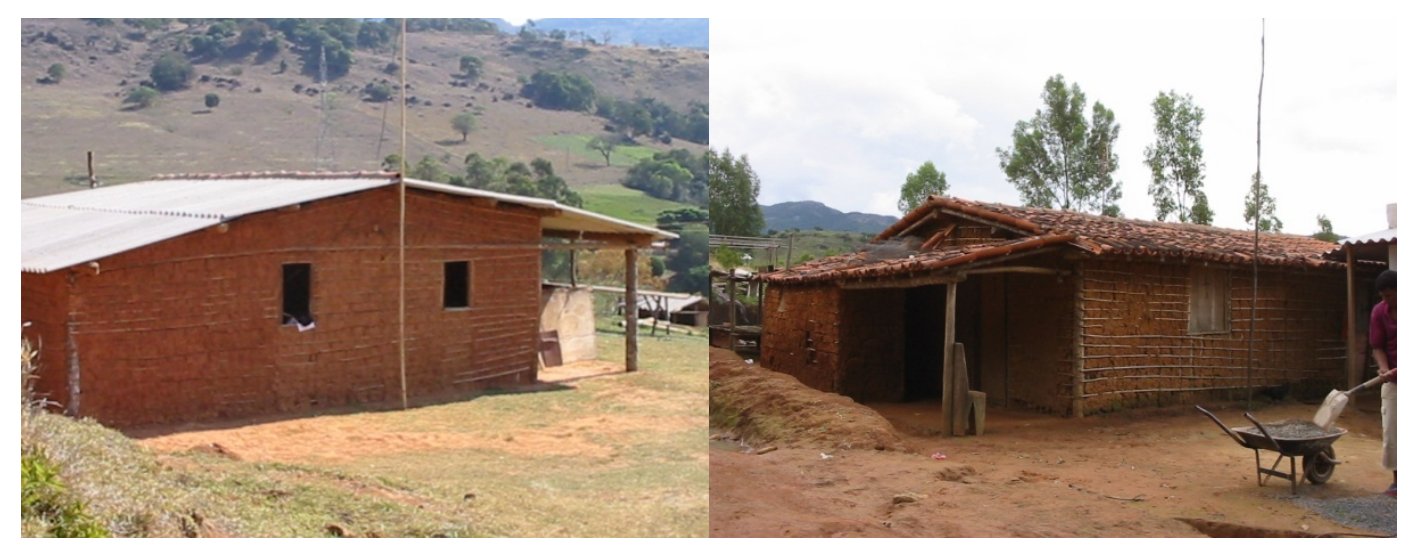

Fig. 2.19. As duas habitações construídas em taipa-de-mão ou pau-a-pique pelos Xucuru-Kariri em Caldas no ano de 2002.

Não somente foi possível verificar in loco os exemplos de habitações em terra ainda existentes na Fazenda Canto, como também resgatar imagens das habitações indígenas alagoanas junto às obras de TORRES(1972) e ANTUNES(1973), que 
aparecem nas obras "A terra de Tiixi e Txiliá" e "Wakona-Kariri-Xukuru", que versam sobre as origens dos índios Xucuru-Kariri.

Depois de uma caminhada de cerca de uma hora, logo ao chegar à Fazenda Canto havia uma habitação construída em taipa de mão. Mais adiante, no local onde há a maior concentração de habitações, outros exemplares em que houve o emprego da taipa-de-mão também foram encontrados, como pode se observar na fig. 2.20.

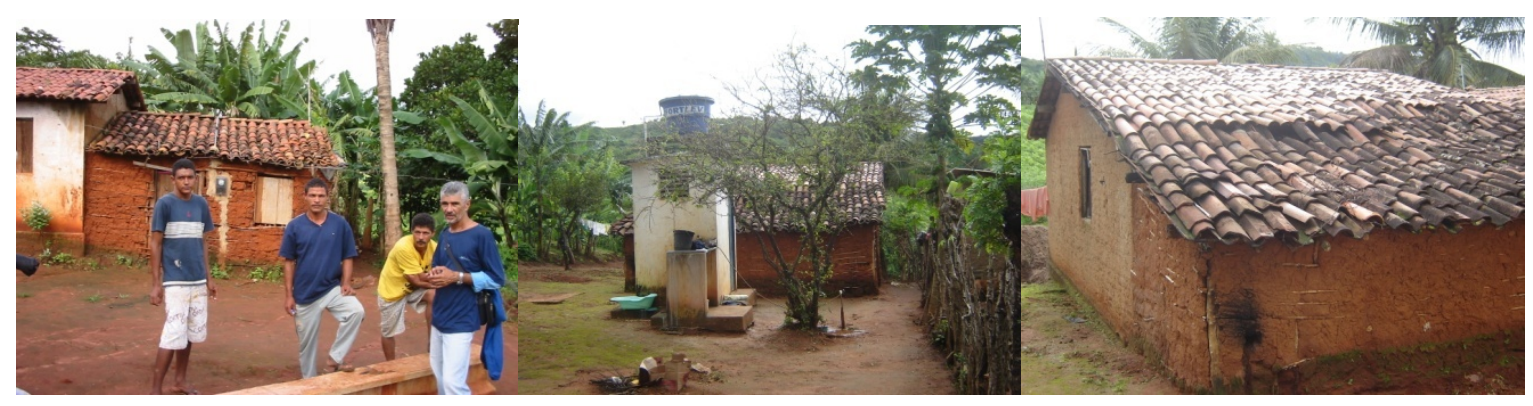

Fig,2.20. Habitações Xucuru-Kariri encontradas na Fazenda Canto, em Palmeira dos Índios em 2006.

Ainda que haja exemplares construídos com terra crua, as novas habitações, construídas sob a responsabilidade do governo, foram edificadas através de alvenaria convencional, embora os livros que contam sobre os Xucuru mostrem uma série de habitações construídas com o emprego da terra, como se observa na fig. 2.21.

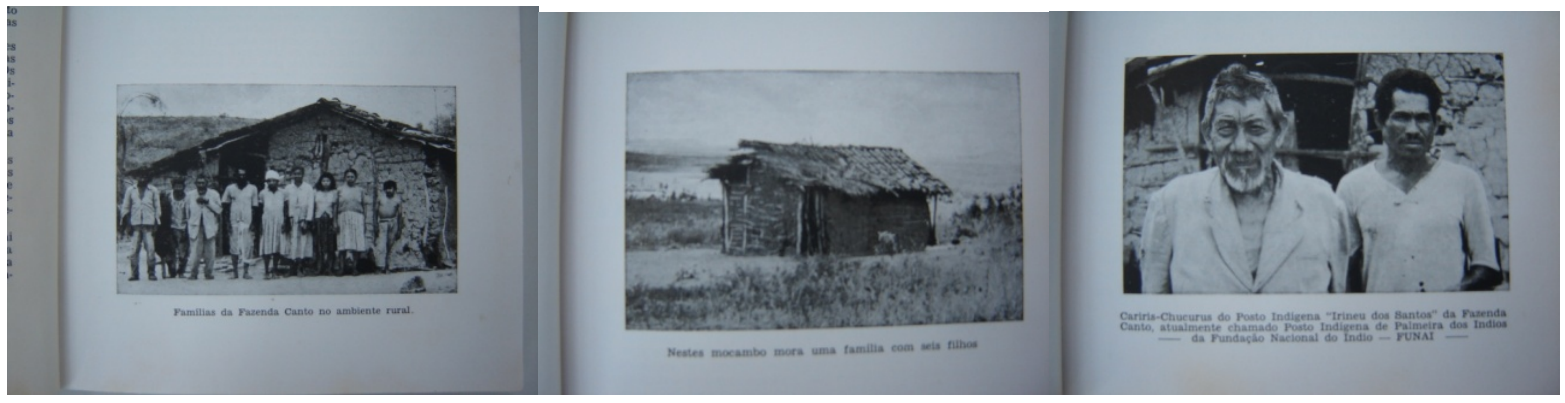

Fig.2.21.Três imagens de habitações em terra Xucuru-Kariri extraídas da obra de ANTUNES (1973): WakonaKariri-Xukuru. 
Além disso, foram encontrados outros documentos acerca dos Xucuru-Kariri, em Palmeira dos Índios, que comprovam a utilização da terra em suas habitações ${ }^{18}$. Em ANTUNES $(1973,74)$ observa-se: "os Wakõná-Kariris-Chucurus, caboclos ${ }^{19}$ mestiços e remanescentes, vivem como agricultores pobres, morando em casas de taipa ou de tijolos, cobertas de telhas ou de palhas. Muitas famílias possuem até 12 ou 13 filhos, na maior indigência. Todos vivem sob responsabilidade própria. Sua religião é católica e cultivam suas crendices primitivas".

Também, durante a pesquisa encontrou-se referência sobre a utilização da terra na obra de BANDEIRA (1972-26), que relata sobre os Kariri de Mirandela, etnia que também contribuiu para a origem dos Xucuru-Kariri. Segundo a autora: "as casas são espaçosas e arejadas. Paredes de adobe ou tijolo ou sopapo, a que chamam de taipa. Piso de rústicos ladrilhos quadrados ou de cimento. Quintais cuidados, alguns com flores. Nos quintais criam porcos, cágados, galinhas. Há quem plante hortaliças, outros têm fruteiras. Têm, no fundo do quintal, sentinas primitivas, mas o uso do bacio (urinol) é muito mais arraigado". Tal descrição condiz com a implantação encontrada em algumas moradias junto à Reserva de Caldas, como se verifica na fig. 2.22.

\footnotetext{
${ }^{18}$ Os Xucuru-Kariri também utilizavam a terra para confeccionar suas urnas mortuárias, as igaçabas. Há exemplares encontrados durante escavações pela região que hoje fazem parte do acervo do Museu Xucuru, que ocupa a Igreja do Rosário, na cidade de Palmeira dos Índios.

${ }^{19}$ Conforme Buarque de Holanda(1986: 306): "caboclo é uma palavra originária do Tupi kari'boka: procedente do branco, mestiço de branco com índio, cabiboca, carijó. Também Melatti(1972: 103) afirma em nota: "o termo cabloco tem várias acepções, segundo a região e a época, conforme ensina Plínio Ayrosa (1935: 65-70). A etmologia da palavra é, no entanto, a que Ihe foi dada por T. Sampaio (1928:174): vem do caá-boc, do tupi, significando "tirado ou procedente do mato"."
} 


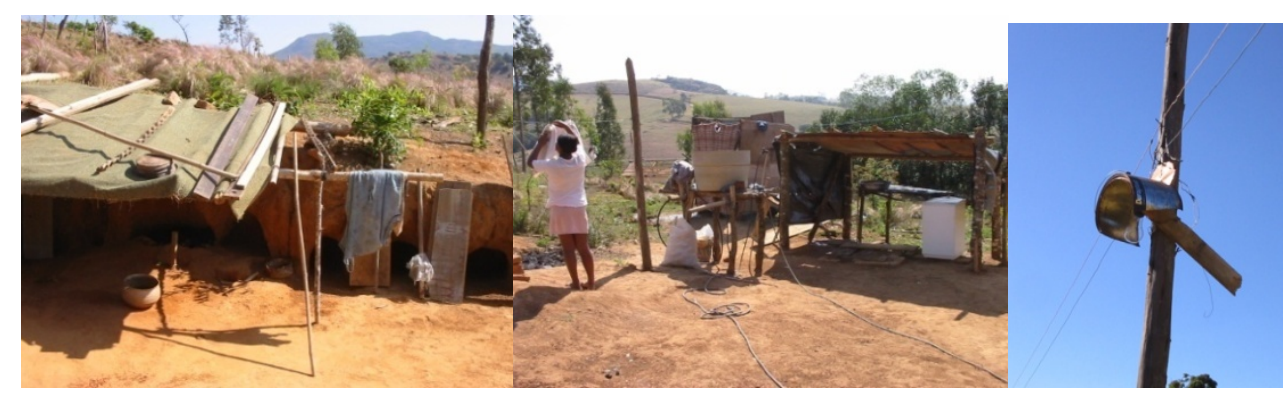

Fig. 2.22. Nas imagens percebe-se, ainda que precárias, as instalações para utilização como banheiro e lavanderia e locais escavados na terra que se destinam ao abrigo e proteção dos animais domésticos ou criações, assim como se observa também o cuidado de inserir nos quintais um sistema de iluminação (concepção de uma luminária com o emprego de lata vazia).

A mesma autora apresenta na obra anteriormente referida um Levantamento dos Tipos de Habitação e Equipamento dos Kariri de Mirandela, comprovando que também este grupo, que acabou miscigenando e originando os Xucuru-Kariri, empregava a terra como material estrutural em suas construções. Tal levantamento encontra-se anexo.

Em período imediatamente posterior às duas construções de terra executadas na Fazenda Boa Vista, os índios iniciaram extensas reivindicações junto às autoridades civis e religiosas de Caldas e região, uma vez que, além de sofrerem com as baixas temperaturas da região, necessitavam de maior número de habitações. Foi exatamente neste período que, através da Diocese de Pouso Alegre, um grupo de religiosos holandeses, ligados à Igreja de São Pedro de Caldas, sensibilizou-se pela causa indígena e construiu, através de tecnologia convencional que emprega blocos de concreto, uma unidade de habitação com cerca de 55 m2, construção cujo custo, segundo relato dos índios e de pessoas ligadas ao pároco de São Pedro de Caldas, chegou a $\mathrm{R} \$ 20.000,00$ (vinte mil reais). Tal construção não foi totalmente concluída (não recebeu pintura externa e vidros) e suas condições atuais podem ser constatadas na fig. 2.23. É esta edificação que serviu como referência de tecnologia 
convencional para o estabelecimento de comparações do desempenho térmico, assunto que será discutido no terceiro capítulo da pesquisa.

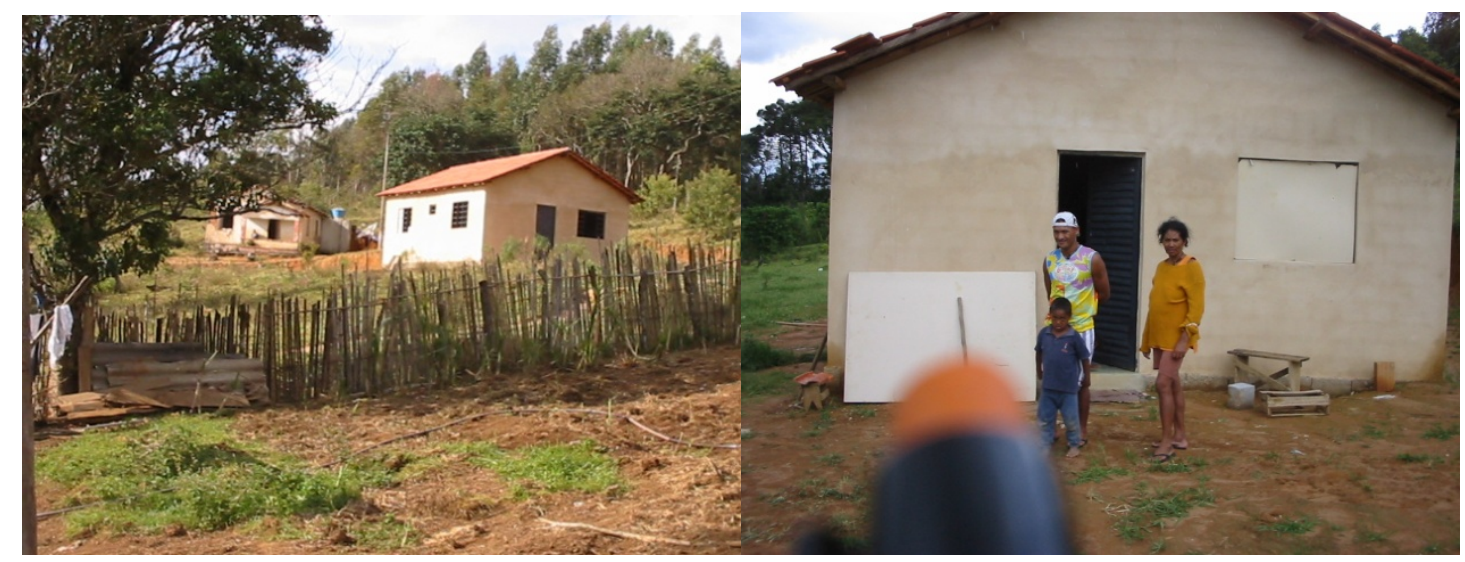

Fig.2.23. Habitação construída em tecnologia convencional com recursos da comunidade religiosa de São Pedro de Caldas.Fotos: Parisi, R.S.B., março/2003.

Foi neste período que a PUC-Minas, campus de Poços de Caldas, interou-se da existência de um grupo indígena remanejado de Alagoas para o estado de Minas Gerais. Foram realizados contatos iniciais, a partir do mês de junho do ano de 2001, em que, através de entrevistas gravadas e transcritas por PEREIRA Fo.(2002), os índios solicitavam a construção de novas habitações, além de se queixarem das dificuldades para obtenção de alimentos e do frio que estavam padecendo na região.

Desde então a Universidade procurou, através da colaboração de professores do Curso de Arquitetura e Urbanismo, conhecer a Reserva e buscar soluções no sentido de viabilizar a construção de novas habitações.

No final do ano de 2002, quando a Igreja Católica empreendeu em sua campanha da Fraternidade, o lema "Por uma terra sem males", o Núcleo de Ciências Humanas da PUC-Minas constatou que o sul do estado não utilizara a verba arrecadada para 
os índios durante esta Campanha da Fraternidade, já que desconhecia a existência de grupo indígena na região.

Assim, com o empenho do então Bispo Revmo.Pe. D. José Geraldo Oliveira do Valle, junto à Associação Cáritas Brasileira, depois de mais de um ano de negociações, em julho do ano de 2004 foi liberada a referida verba que acabou destinada à construção de novas habitações para os Xucuru-Kariri de Caldas.

Previamente, foi projetada a utilização do recurso para a construção de duas ou três habitações. Embora o anseio dos Xucuru-Kariri de Caldas fosse viabilizar três ou mais moradias no menor espaço de tempo possível, independente da forma e tecnologia que seriam empregadas, estudos sobre tecnologias construtivas foram realizados entre 2002 a 2004, no sentido de se buscar uma forma de construção que se aproximasse daquela conhecida pelos Xucuru-Kariri, ou seja, que empregasse a terra como material de construção.

Os estudos sobre o emprego da terra chegaram à conclusão de que este material, além de renovável, ecológico e sustentável, pela grande quantidade disponível na própria Reserva de Caldas, poderia possibilitar a redução do custo das habitações caso a comunidade local se envolvesse no processo construtivo.

De acordo com Minke (2001:16-19), em comparação com materiais industrializados comuns, "o emprego da terra tem muitas vantagens:

1. A terra regula a umidade ambiental;

2. A terra armazena calor;

3. A terra agrega energia e diminui a contaminação ambiental; 
4. A terra é reutilizável;

5. A terra economiza materiais de construção e custos de transporte;

6. A terra é apropriada para autoconstrução;

7. A terra preserva a madeira e outros materiais orgânicos;

8. A terra absorve contaminantes".

Salienta-se que, além dessas vantagens, a redução de custos poderia também ocorrer se os índios da comunidade se envolvessem durante o processo construtivo. Aparentemente, os Xucuru-Kariri estavam bastante interessados em ter novas moradias na aldeia que fossem construídas com o aperfeiçoamento da taipa que conheciam.

Assim, no início do $2^{\circ}$ semestre de 2004 , foram realizadas com os índios as Oficinas de Conscientização, Conhecimento e Transferência de Tecnologia. Foram mostradas ao grupo algumas tecnologias semelhantes ao pau-a-pique ou taipa de mão, empregadas há muitos anos em vários países latino-americanos, e que apresentavam alguns melhoramentos em relação à tecnologia que conheciam desde o período em que habitavam no Nordeste, como anteriormente afirmado.

Tais tecnologias latinoamericanas são o Bajareque, empregado em todo o México, principalmente ao sul do país, o Bahareque, utilizado na Colômbia, na Venezuela e no Equador, Peru, Argentina e também a Quincha, amplamente utilizada no Peru, Equador, Colômbia e Argentina, entre outros. Deve-se salientar que essas tecnologias são empregadas há muitos séculos, desde o período das civilizações pré-colombianas. Como será possível observar, muitos exemplares de edificações 
confeccionadas em bajareque, bahareque e quincha por toda a América do Sul ainda podem ser encontrados em diversas localidades.

O grande problema do emprego da taipa de mão ou pau-a-pique, tal como os índios conheciam, reside no fato do rápido desgaste de seu embasamento, decorrente da não realização de meios de proteção que evitem o contato entre a ossatura/ entramado e da argamassa de terra com o solo úmido. Conforme aponta FARIA (2002:29), traduzido de MEUNIER (1988), "uma boa casa de terra precisa ter um bom par de botas e um bom chapéu".

Tal proteção pode ser realizada através do emprego de camada de pedras ou quaisquer outros materiais impermeáveis, que serão detalhados no tópico 2.12 do presente trabalho.

No que diz respeito ao emprego da taipa de mão ou pau-a-pique, deve ser apontada a preocupação da FUNAI e da FUNASA relativa ao temor da possibilidade de focos de contaminação da Doença de Chagas, através do aparecimento de focos do barbeiro infectado pelo Trypanosoma cruzi, agente transmissor da doença ${ }^{20}$.

Segundo PINTO DIAS e DIAS (2004: 09) "bastante importante é a particularidade de que quase sempre os barbeiros evacuam logo depois de uma refeição: acontece que é nas fezes dos barbeiros contaminados que virão os tripanosomas, microorganismos causadores da Doença de Chagas. Penetrando pelo próprio local

\footnotetext{
${ }^{20} \mathrm{O}$ barbeiro acaba se alojando entre frestas e rachaduras da argamassa de terra e da ossatura da edificação e, a partir daí, se o inseto estiver contaminado, pode haver a proliferação da Doença de Chagas. Fonte: http://www.scielosp.org/scielo.php?script=sci arttext\&pid=S0102-311X2000000800003 último acesso em março 12008.
} 
da picada do barbeiro, esses tripanosomas poderão invadir a pessoa ou animal sugado, e assim irá ocorrer a transmissão da Doença de Chagas. Todos os barbeiros nascem livres do microorganismo da Doença de Chagas, mesmo que seus pais estejam infectados. O barbeiro só adquire os tripanosomas se sugar uma pessoa ou animal contaminado. Essa é a razão pela qual são encontrados na natureza muitos barbeiros não infectados, principalmente aqueles que só se alimentam do sangue das aves, pois essas não albergam o Trypanosoma cruzi".

A FUNAI e a FUNASA, que são entidades governamentais responsáveis pelo cuidado com os povos indígenas do Brasil, veem com muita reserva na atualidade a reprodução das construções em terra pela possibilidade do surgimento de novos focos da doença que o Brasil, há alguns anos, procura erradicar. Além do mais, essas entidades realizam um trabalho 'paleativo' na tentativa de minimizar os focos de proliferação da doença através da demolição de habitações de taipa ou pau-apique e a construção de novas moradias através de sistemas convencionais. Tal atitude, seguramente colabora com o processo de destruição e esquecimento da história das tecnologias construtivas empregadas no Brasil desde o período colonial.

\subsection{O Bajareque, o Bahareque e a Quincha: referências para a adaptação de uma tecnologia construtiva.}

O Bajareque Mexicano é uma tecnologia ancestral daquele país, empregada desde os tempos da civilização Maia. CASTAÑEDA E GONZÁLES(2001) informam que "Vicente Guzmán Ríos discorre que este tipo de habitação tradicional tem como antecedente ser de origem pré-hispânica e que é o protótipo da habitação maia 
considerado o mais antigo do México. Autores como MOYA (1988) definem o bajareque como 'embarro ou enjarre, salientando que na Costa do Pacífico se chama bajareque, na Costa Huasteca denomina-se enjarre, em regiões do golfo é chamado de embarro e em Yucatán denomina-se packlúm (em maia)". Este mesmo autor afirma que os expoentes mais importantes se encontram nos lugares anteriormente mencionados e também em Chiapas, estado do sul do México, onde os mayas ocuparam grande extensão territorial. Da mesma forma o bajareque ${ }^{21}$ também pode ser encontrado em países da América Central e da América do Sul, assim como em parte do centro da África e em alguns países europeus como Dinamarca, Áustria, Iuguslávia e Escócia", como se observa nos dois exemplares da fig.2.24.
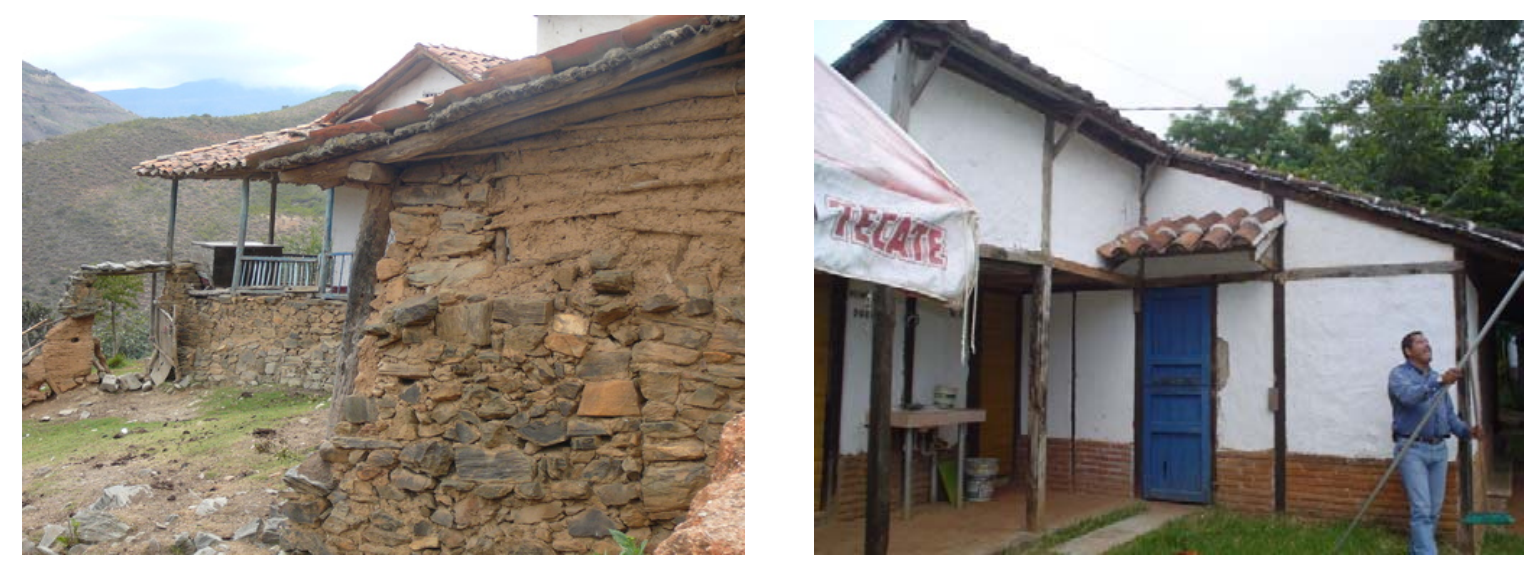

Fig,2.24. Casa de bahareque na Venezuela, próxima à San Jose del Sur, Mérida e casa de bajareque no México, em sistema adaptado por Arturo Gonzáles.

Assim como a taipa de mão ou pau-a-pique no Brasil, infelizmente, o bajareque como tecnologia construtiva, é muitas vezes associado à pobreza. De acordo com VIÑUALES,G.(2002:143-162): "O bajareque é um sistema construtivo de terra sobre entramado, o mesmo que bahareque, pajareque, quincha".

\footnotetext{
${ }^{21}$ Bajareque e Bahareque são a mesma tecnologia com pequenas diferenciações em seus processos construtivos. A grafia diferente se deve principalmente a questões do emprego do espanhol nos diversos países latino-americanos.
} 
Há alguns anos, arquitetos mexicanos ligados ao CYTED realizaram, após Talleres de Transferência Tecnológica, modificações sutis no bajareque, no sentido de agregar à tecnologia melhoramentos que a tornassem mais resistente e duradoura. Nas fichas da publicação denominada "Un techo para vivir. Tecnologias para viviendas de produccion social en America Latina"22, elaborada e disseminada pelo HABYTED ${ }^{23} /$ CYTED, constam as modificações realizadas tanto no bajareque, quanto na quincha, no sentido de gerar uma contribuição para a melhoria do habitat latinoamericano. A tecnologia construtiva do bajareque adaptado passou a ser conhecida como bajareque mejorado, pois procurou melhorar a estrutura portante do sistema construtivo, além de criar uma camada de isolamento e proteção contra a umidade ascendente do solo através do emprego de cinco a oito fiadas de tijolos cozidos, recobertos com sacos plásticos reutilizáveis ou por capa betuminosa. Além disso, depois da aplicação do embarre, há o emprego de malha de galinheiro com o propósito de promover a maior aderência da argamassa de revestimento à parede de terra armada. $\mathrm{Na}$ argamassa de revestimento, acabaram agregando uma pequena porcentagem de cimento à mistura de terra, cal e água.

Alguns arquitetos vinculados ao COCOES de Tuxtla-Gutierrez, em especial Arturo López González, acabaram empreendendo esforços para a disseminação do Bajareque Adaptado e Mejorado. Com o apoio da UNACH, em 2002 este profissional elaborou uma publicação denominada "Mi casa de Bajareque", com o objetivo de fomentar a utilização da mesma em experiências de autoconstrução. Em 2005,

\footnotetext{
${ }^{22}$ Esta foi uma publicação organizada por Lorenzo Gálligo,P.(2005), com apoio da UPC. Barcelona: CYTED/UPC. 559p.É disponibilizada também em CD-ROM.Na introdução (p.2) da referida publicação consta: " Un techo para vivir é uma contribución a la mejora del hábitat latinoamericano".

${ }^{23}$ O Habyted é o Subprograma do Cyted que concrega especialistas e instituições comprometidas no Desenvolvimento Sustentável e equitativo do Habitat Social Iberoamericano, cooperando com os atores, gerando e transferindo tecnologias sociais, econômicas, políticas, de gestão e produção da habitação.
} 
patrocinado pelo Governo do Estado de Chiapas e COCOES, elaborou o "Manual de Autoconstrucción: Aula Rural de Bajareque". De acordo com ESCAMIROSA MONTALVO (2005), “o modelo arquitetônico de autoconstrução elaborado por Arturo López Gonzáles permite flexibilidade no desenho, adaptando-se facilmente à topografia do terreno em que será implantado e às necessidades que se tenham. Resgata os materiais e procedimentos construtivos ancestrais assim como os "benefícios climáticos" do bajareque e, o mais importante, diminui o custo da construção, a partir do uso, majoritariamente, de materiais naturais e do emprego da mão-de-obra local". Esta tecnologia adaptada pode ser observada na fig. 2.25, a partir da ficha extraída de Un techo para vivir.

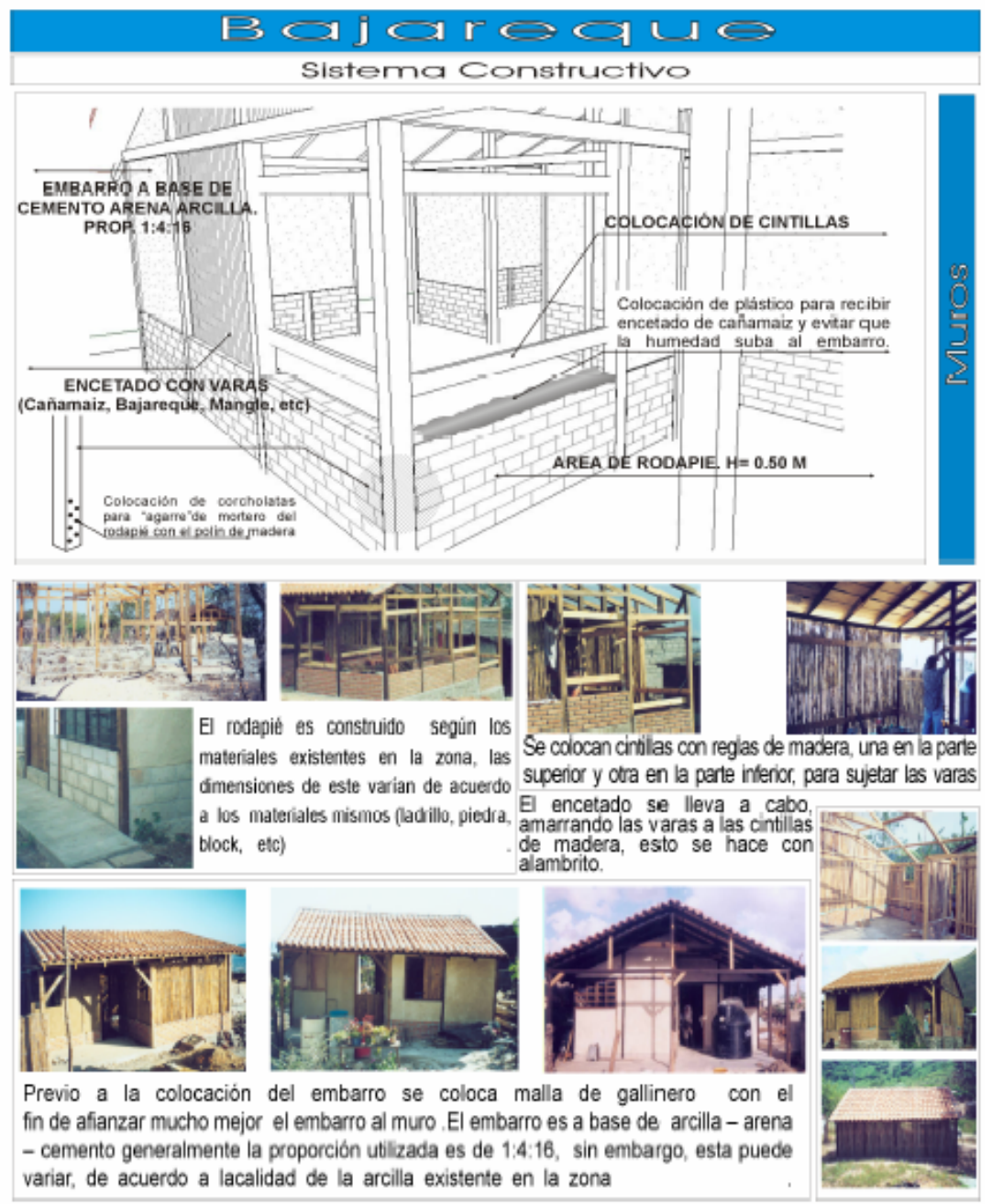

Fig.2.25. Ficha sobre o Bajareque Mejorado da publicação do CYTED denominada Un techo para vivir.pp.193197. 
No que diz respeito à quincha, conforme BAUCHWITZ (2006 ) apud Neves,C.M.M et al (Org.) no trabalho Técnicas Mixtas de Construccíon con Tierra (2003:295-299), "a palavra quincha, no vocabulário quéchua, está vinculada ao uso da cana, (para os brasileiros do caule de milho). Em algumas partes da América Latina se chama comumente quincha aos procedimentos construtivos que utilizam caule de milho para conformarem ossaturas estruturais construtivas, geralmente simples. Para que não seja confundido com algumas variantes de bahareque ou bajareque, se reserva o termo quincha para se referir a um original sistema construtivo anti-sísmico que se desenvolveu no Peru desde a época do Vice-Reinado para edificar o segundo e, algumas vezes, o terceiro piso dos imponentes edifícios urbanos que tinham seu pavimento térreo construído com técnicas mistas de construção como o adobe. Desde épocas muito antigas, se utilizou este sistema na construção de casas de camponeses peruanos. Sua estrutura estava constituída de ramos e troncos de árvores roliços, unidos entre si por meio de fibras vegetais. Sobre esta armação se dispunha um tecido de caules de milho para formar as paredes, que eram recobertas com finas camadas de barro. A tecnologia foi utilizada principalmente na região do litoral e costa, onde havia milho em abundância além de as condições climáticas serem propícias ao seu emprego".

Esta quincha tradicional, por conta de sua excepcional resistência ao tempo e aos sismos, acabou por inspirar centros de investigação peruanos como o ININVI (Instituto Nacional de Investigação e Normalização da Vivenda) ou o da PUCP (Pontifícia Universidade Católica do Peru) a resgatarem a antiga tecnologia, adaptando-a às exigências modernas, com o emprego de técnicas mistas de construção com terra como solução alternativa para as habitações de baixo custo. 
Foram estudados, adaptados e propostos dois sistemas de Quincha pré-fabricada: a Quincha Prefabricada Cheia, desenvolvida pelo ININVI, e a Quincha Prefabricada Leve, desenvolvida pela PUCP com a colaboração do Sistema Nacional de Defesa Civil.

Verifica-se, na fig.2.26, a ficha descritiva da Quincha Pré-Fabricada desenvolvida pela Universidade Nacional de Engenharia.

\section{FICHA 1: DESCRIPCION GENERAL}

\section{RASGOS TECNOLÓGICOS}

La Quincha Pretabricada es un sistema constructivo que utiliza paneles prefabricados, formados por basticlores de madera aserrada, rellenados con bambusas (carrizo redondo, caña brava o tiras de bambù) trenzada en el bastidor. Los paneles son montados y fijados constituyendo los muros de la wivienda; son revocados con barto mezclado con paja en la primera etapa; finalmente reciben una última capa que puede ser de barro, cemento, yeso, una mezcla de éstos u materiales. El techo apoyado en la viga solera es inviano, con estructura de madera y cobertura de caña, torta de barro con paja teja demicro-concreto.

\section{RASGOS SOCIO PRODUCTIVOS}

El sistema de Quincha Prefabricada, resultado del mejoramiento y racionalización de la quincha tradicional peruana, es una propuesta altemativa de viviendas de bajo cosio, para aquellos lugares donde abundan la madera y las bambusas. Por su poco peso es ventajoso parazonas de riesgo sismico.

La simplicidad de los procesos de fabricación de los paneles, su montaje y las operaciones complementarias para construir la vivienda, hacen fácil el aprendizaje del sistema para autoconstructores, inclusive para mujeresh.

El uso de este sistema en la construcción de viviendas puede formar parte de un mercado de trabajo, a través de micro-talleres u atras formas de asociación para fabricar paneles o construir.

\section{CARACTERISTICAS TECNOLOGICAS DEL COMPONENTE}

\begin{tabular}{|c|c|c|c|}
\hline Ancho & Altura & Esp. & $\begin{array}{l}\text { Cañas } \\
\text { Unidaties }\end{array}$ \\
\hline $\begin{array}{l}1.20 \\
0.60\end{array}$ & 2.40 & 0.065 & 37 \\
\hline
\end{tabular}

Fig.2.26. Ficha da Quincha Pré-Fabricada da publicação do CYTED denominada Un techo para vivir". p.181-187. 


\subsection{Experiências alternativas para construções em terra no Brasil}

Não se pode deixar de mencionar as experiências brasileiras contemporâneas alternativas para as construções de terra. Na década de 1930 o arquiteto Lúcio Costa foi contratado para apresentar uma alternativa para a Vila Operária que seria construída em João Monlevade, pela empresa Belgo-Mineira. Grande observador das raízes do Brasil e atento à leitura e às especificidades do lugar, Lúcio elaborou uma proposta em que as unidades de habitação seriam construídas em taipa de mão ou pau-a-pique, sobre lajes montadas em pilotis. Ao apresentar a proposta, Lúcio Costa escreveu: “...faz mesmo parte da terra, como formigueiro, figueira-brava e pé-de-milho - é o chão que continua... Mas justamente por isso, por ser coisa legítima da terra, tem para nós, arquitetos, uma significação respeitável e digna, enquanto a pseudonominação, 'normando ou colonial', não passa de um arremedo sem compostura". Ao final, o arquiteto aconselhava: "devia ser adotada para casas de verão e construções econômicas de um modo geral. É uma técnica muito mais barata, atende aqueles casais remediados que desejam uma casinha de campo".

Infelizmente, a Belgo-Mineira recusou a proposta e o projeto de Lúcio Costa, que pode ser observado na fig.2.27 acabou engavetado.

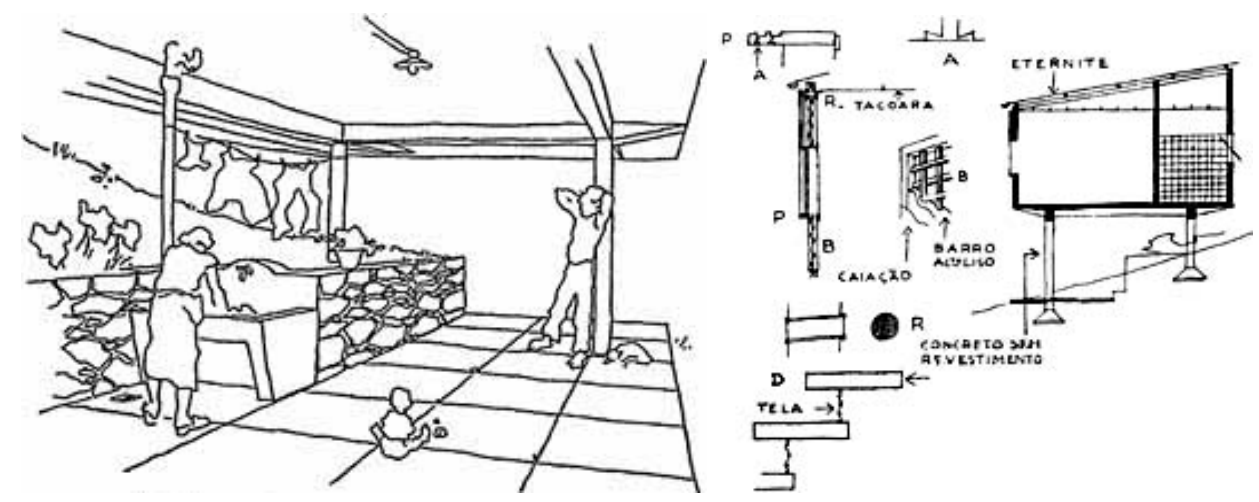

Fig. 2.27. A taipa moderna: croquis da proposta para a Vila Operária de Monlevade, projeto de 1934 do arquiteto Lúcio Costa. 
Em 1962, o arquiteto pernambucano Acácio Gil Borsói, sensibilizado com uma situação que se apresentava junto à região metropolitana do Recife, na comunidade do Cajueiro Seco, desenvolveu uma proposta baseada no conhecimento popular propondo a pré-fabricação de painéis como madeira serrada. Segundo o arquiteto (1982), "a proposta visava racionalizar e pré-fabricar um processo construtivo dos mais antigos do mundo e que, no Brasil, representa ainda hoje um sistema construtivo que traduz o conhecimento de mais da metade da população". A fabricação em série de poucos tipos de painéis permitiria uma construção mais fácil e ainda possibilitaria a variedade dentro das condições econômicas e do interesse de cada família. A experiência foi realizada em duas etapas: a fabricação e montagem dos painéis, a fixação e grampeamento da estrutura entramada e em seguida, os painéis foram tratados e imunizados, como podem ser vistos na fig.

2.28 .

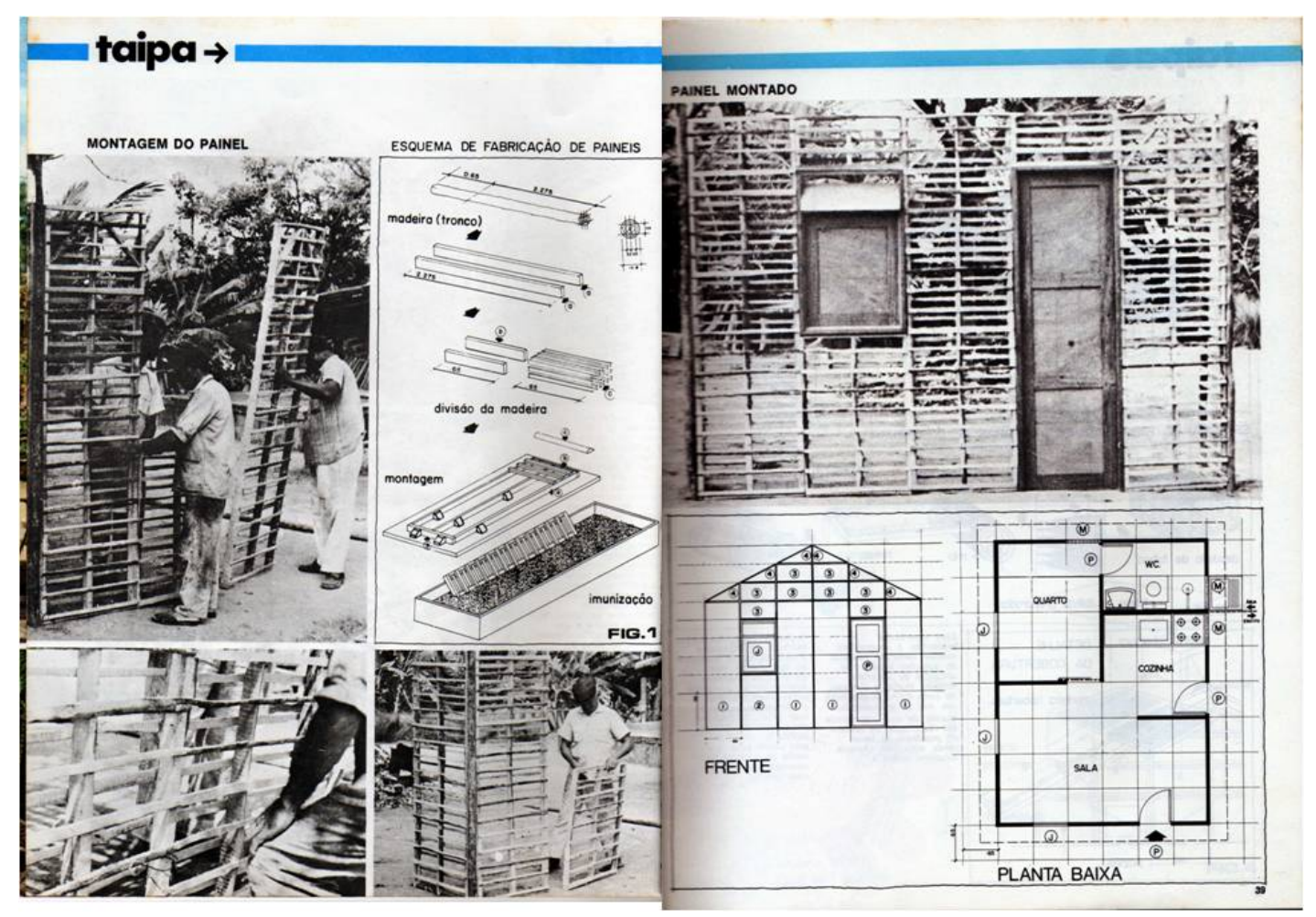

Fig. 2.28. Detalhes do sistema construtivo proposto por Borsói para a Região Metropolitana do Recife. 
A segunda etapa, individual, começava com o entendimento e escolha pelos proprietários do arranjo e disposição dos cômodos de suas casas, para, em seguida, adquirir os tipos de painéis necessários para a sua montagem. As portas e janelas também foram padronizadas. Para a cobertura, até pelo fato de possibilitar uma releitura da cobertura das antigas moradias do Cajueiro Seco, foi utilizada uma esteira de palha, sapê ou capim, também tratada em uma pequena fábrica, onde foram confeccionados os feixes desse material natural, costurados com fio de nylon, que acabaram sendo fornecidos em rolos. Ainda de acordo com BORSÓl (1982) "essa experiência evidenciou a necessidade sempre maior da pesquisa de soluções locais, com a utilização de materiais também locais e traduziu, de certa forma, o problema que nos foi apresentado, quando de uma experiência em reabilitação de núcleos de população de baixa renda, onde, não obstante existirem tijolos à disposição para a construção das casas, a população não consegue utilizá-los - ou os utiliza mal- por completo desconhecimento em relação ao sistema construtivo. A taipa, por sua vez, permite o emprego da mão-de-obra de toda a família: o homem arma o esqueleto da casa e a mulher e as crianças tecem e vedam com barro as paredes". Quando do início do período da Ditadura Militar no Brasil, a partir de 1964, esta significativa experiência foi descartada e esquecida, já que, infelizmente, não atendia aos interesses de controle e lucro do sistema político-econômico em vigor.

Seguramente, o estudo das tecnologias latino-americanas e o entendimento de experiências brasileiras deram subsídios para a proposição de uma adaptação tecnológica da taipa de mão e do bajareque mejorado, que se concretizou através da 'novaterra', um dos objetos deste trabalho. 


\subsection{A proposta das habitações em 'Novaterra'}

As tecnologias construtivas anteriormente apresentadas, tendo como referência o pau-a-pique ou taipa de mão do Brasil junto às experiências de países vizinhos, serviram para dar subsídios à proposta construtiva que foi apresentada ao grupo Xucuru remanescente, para quem o emprego da terra como principal material construtivo estaria mantido, como já afirmado anteriormente.

Além das importantes qualidades destacadas para a utilização da terra na construção civil, agrega-se o fato de este material natural conservar o calor no interior da edificação e assim desempenhar importante papel como regulador de temperatura entre ambiente exterior e interior e, dessa maneira, atenuar uma queixa constante dos Xucuru de Caldas: "aqui é muito bom, porém o frio é muito intenso ${ }^{24 "}$.

Outro aspecto considerado e apresentado ao grupo foi o fato, também importante de que, ao se empregar a terra como material de construção, a identidade cultural dos índios Xucuru-Kariri mantinha-se resgatada e reestudada ${ }^{25}$.

Nas oficinas realizadas na Reserva, os membros do grupo puderam apreciar as apresentações do projeto arquitetônico diante do aparelho de televisão. Foram mostradas maquetes virtuais das habitações a serem construídas e os índios acabaram se encantando com o novo sistema construtivo. Deve-se salientar que,

\footnotetext{
${ }^{24}$ Em depoimento recente realizado em junho de 2008, o índio João Pedro Correia, cunhado do Cacique José Sátiro, que mora em Quixaba, mas está passando uma temporada junto de seus familiares na Reserva Xucuru-Kariri de Caldas, quando questionado sobre a razão de não fixar residência na Reserva afirmou que gostava do lugar mas que havia dois problemas ali: as ladeiras e o frio intenso.

25 Este aspecto, infelizmente, como será possível se constatar no decorrer da pesquisa, provavelmente devido a aculturação do grupo, desperta pouco interesse para os Xucuru-Kariri de Caldas.
} 
antes de se realizar a proposta de um projeto arquitetônico específico para os Xucuru-Kariri, foram estudadas as habitações da reserva, assim como foram analisadas as formas de apropriação do espaço doméstico por estes índios, como já comentado anteriormente.

Verificando o terreno e as possibilidades de utilização dos materiais locais, constatou-se a existência de moitas de bambu na própria área da Fazenda Boa Vista, assim como se percebeu que havia o descarte de palha de milho seca que, por um período, era armazenada em um paiol abandonado da propriedade, fato que pode ser constatado na fig.2.29. Tais materiais poderiam, em última análise, ser incorporados ao bajareque mejorado/ taipa de mão, e a tecnologia seria adaptada e contextualizada à região de Caldas.

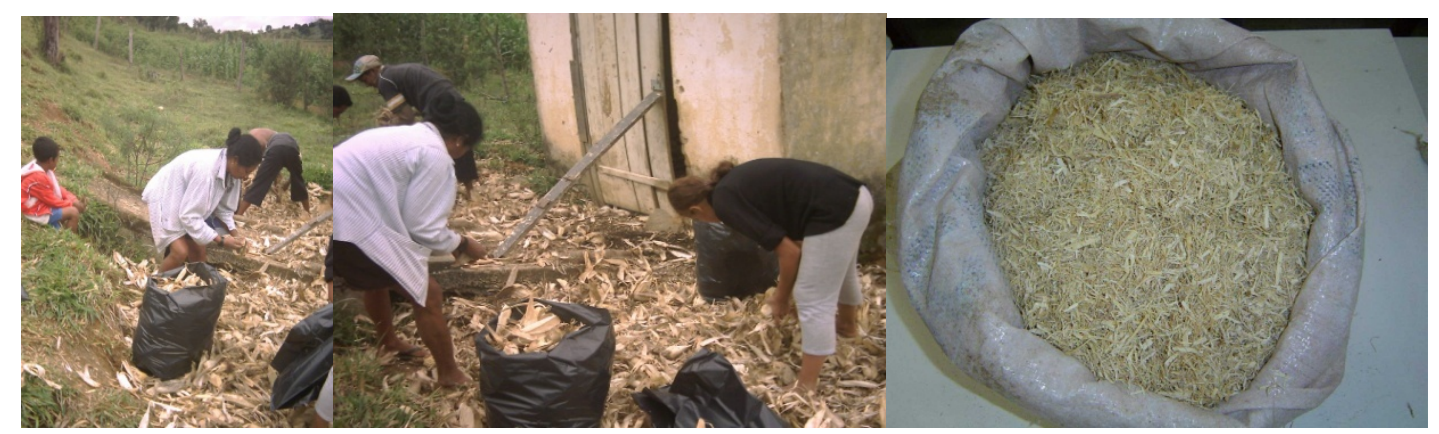

Fig.2.29. A disponibilidade da palha junto à própria reserva indígena pode ser observada através das imagens em que os índios manuseiam a palha diante do paiol. Na seqüência, apresenta-se a palha já triturada.

Finalmente, ao descrever a tecnologia para o Cacique Uarkanã, apresentando-lhe as vantagens que a utilização deste sistema construtivo poderia promover para as novas habitações, o cacique disse então que suas novas casas seriam executadas como 'novaterra', uma vez que a Reserva de Caldas representava para o grupo remanejado a "terra prometida". 
Na fig.2.30 podem ser observados vários momentos das oficinas realizadas na Reserva Xucuru-Kariri em que estiveram envolvidos índios, discentes e docentes da PUC-Minas/Poços de Caldas.

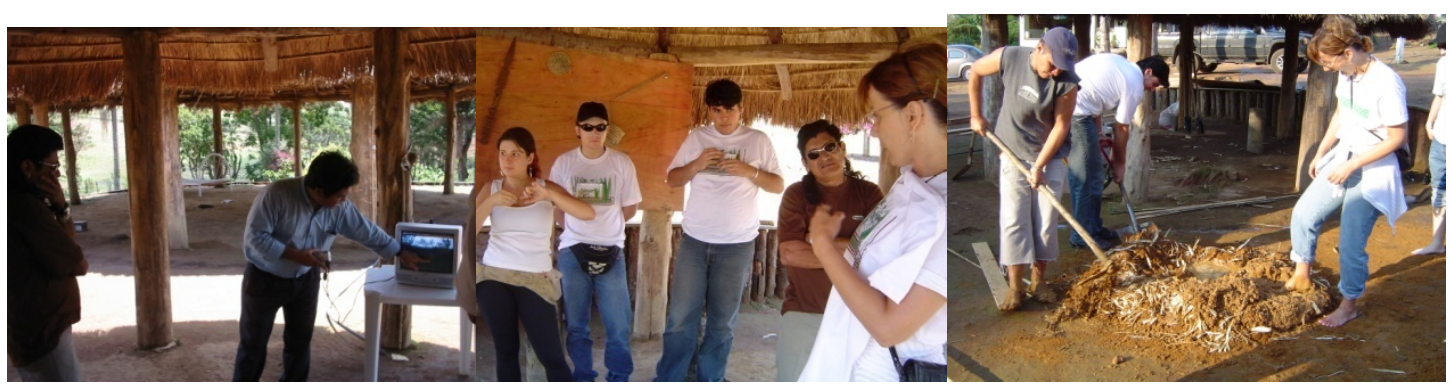

Fig. 2.30. Momentos das Oficinas de transferência de tecnologia, envolvimento e capacitação realizadas na Reserva Xucuru-Kariri de Caldas.

Quando os índios viram as simulações eletrônicas de suas futuras casas, além de maravilhados, imediatamente disseram que era de casas como essas que necessitavam. As simulações eletrônicas da casa de três dormitórios podem ser observadas na fig.2.31.
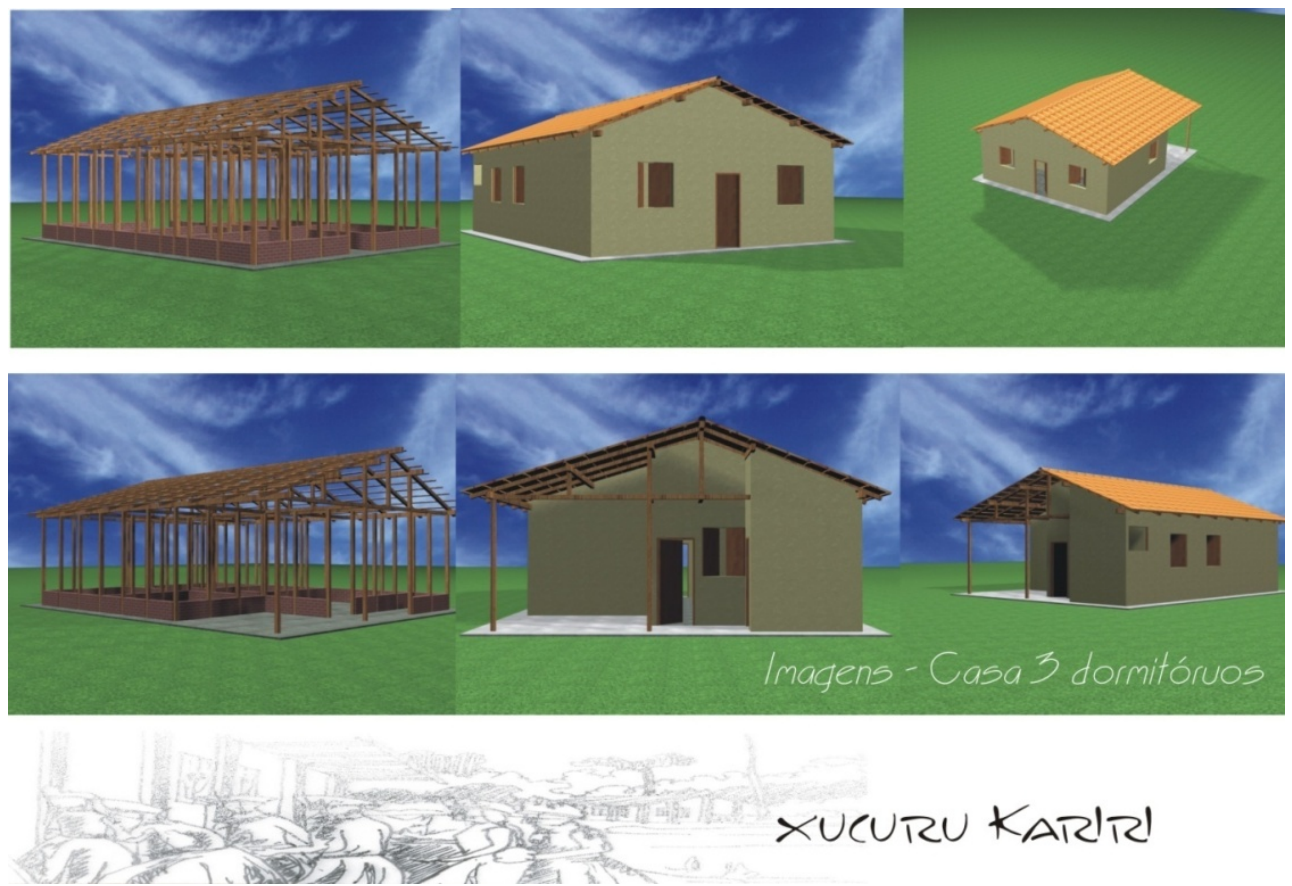

Fig. 2.31. Maquetes eletrônicas de uma casa das casas a ser construída em 'novaterra'. 
O painel de 'novaterra' que pode ser observado na fig.2.32 demonstra as adaptações e diferenças em relação ao bajareque melhorado e à quincha peruana pré-fabricada. Tais modificações dizem respeito à incorporação da palha de milho triturada misturada à argamassa de terra de preenchimento do painel. O emprego de fibras vegetais em construção civil vem sendo estudado por diversas instituições e autores, dentre os quais destacam-se, no Brasil a atuação pioneira do CEPED desde 1980 assim como os trabalhos de AGOPYAN (1991) e SAVASTANO JR. (1997), entre outros.

Para a confecção do entramado e ossatura do painel das habitações dos Xucuru se utilizam varas de bambu abertas após serem extraídas e devidamente protegidas no local. Outra modificação se refere à estrutura de madeira que empregou eucalipto protegido de forma caseira com óleo queimado. Por último, ocorreu também a adaptação do alicerce para a edificação com o emprego de um sistema e materiais convencionais já conhecidos pelos índios.

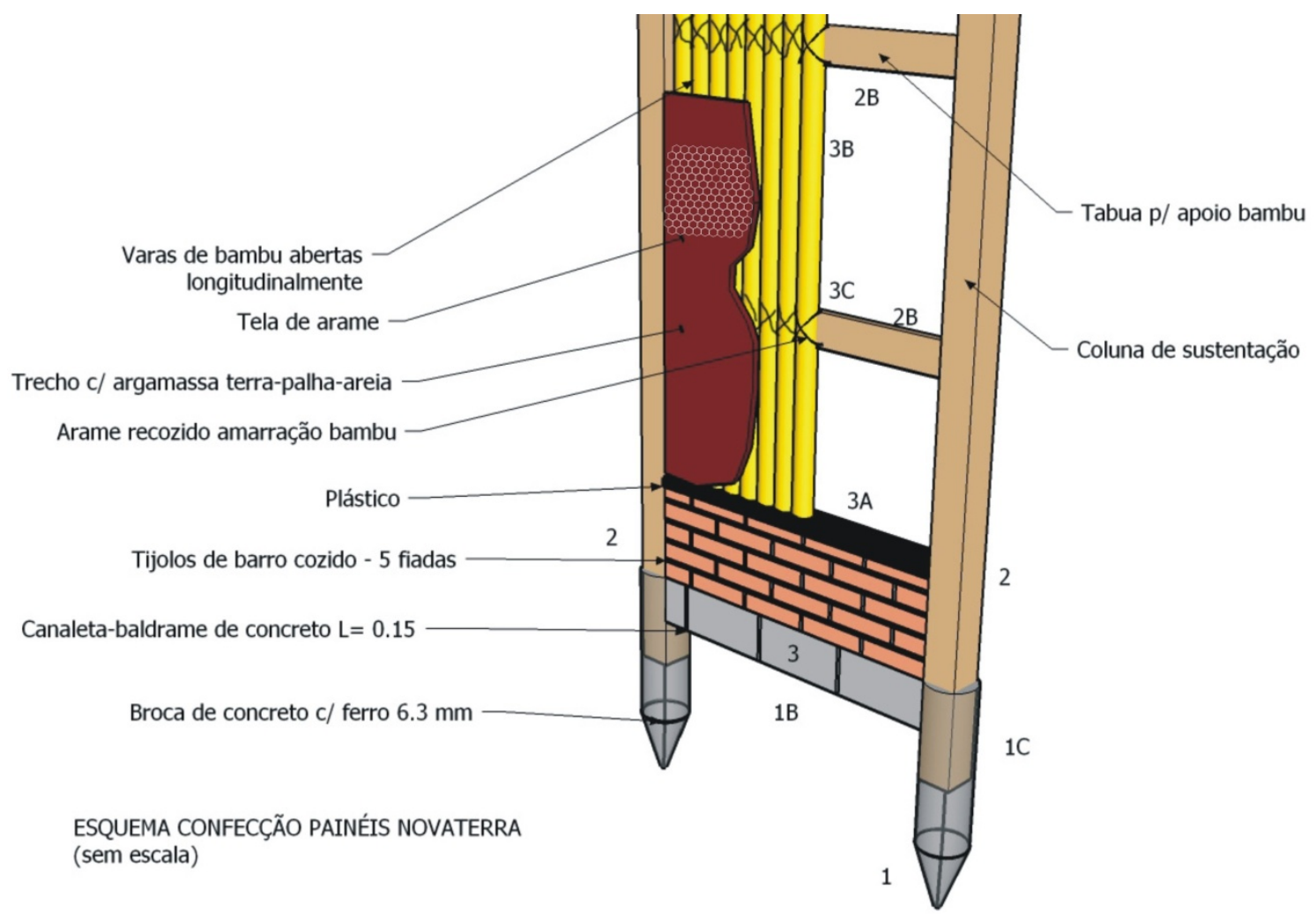

Fig.2.32. Corte do painel modular produzido em 'novaterra'. 
Um aspecto diferencial do sistema proposto como adaptação tecnológica para os Xucuru-Kariri diz respeito ao emprego do forro. Como as queixas dos índios se reportam essencialmente ao conforto interno da moradia, em especial o problema do frio, a pesquisa propõe um forro confeccionado em esteira de bambu que, em alguma medida, aproxima-se da tradição Xucuru e, até mesmo, da tradição indígena da cestaria. Uma vez que estes índios manuseiam bem as palhas, buritis e o bambu tecendo esteiras, cestas e adornos corporais, seria bastante razoável que se envolvessem no processo produtivo da confecção dos forros para suas habitações.

Quando das primeiras visitas à Reserva de Caldas, verificou-se que na edificação utilizada pelos Xucuru-Kariri como moradia do Cacique, havia um cômodo forrado com esteira de bambu confeccionada pelos próprios índios. Desta forma, como o bambu é um material abundante na aldeia, o forro ${ }^{26}$ para as habitações em 'novaterra' proposto seria executado com a esteira de bambu. Porém, desejando agregar uma qualidade térmica à habitação, propôs-se a instalação de uma subcobertura, inserida entre o forro e a estrutura do telhado. A sub-cobertura empregou caixas de leite tetrapak reutilizadas com o propósito de melhorar a qualidade térmica da moradia, tanto no verão quanto no inverno. As etapas do sistema proposto e utilizado podem ser melhor observadas na fig.2.33.

\footnotetext{
${ }^{26}$ No que diz respeito ao forro, como poderá se verificar no capítulo subseqüente, a instalação do mesmo foi executada em apenas em um dormitório da habitação de 'novaterra' e em um dormitório da habitação testemunho (habitação convencional). Esta decisão foi decorrente da insuficiência de recursos para a execução do forro nas duas edificações avaliadas por este trabalho.
} 


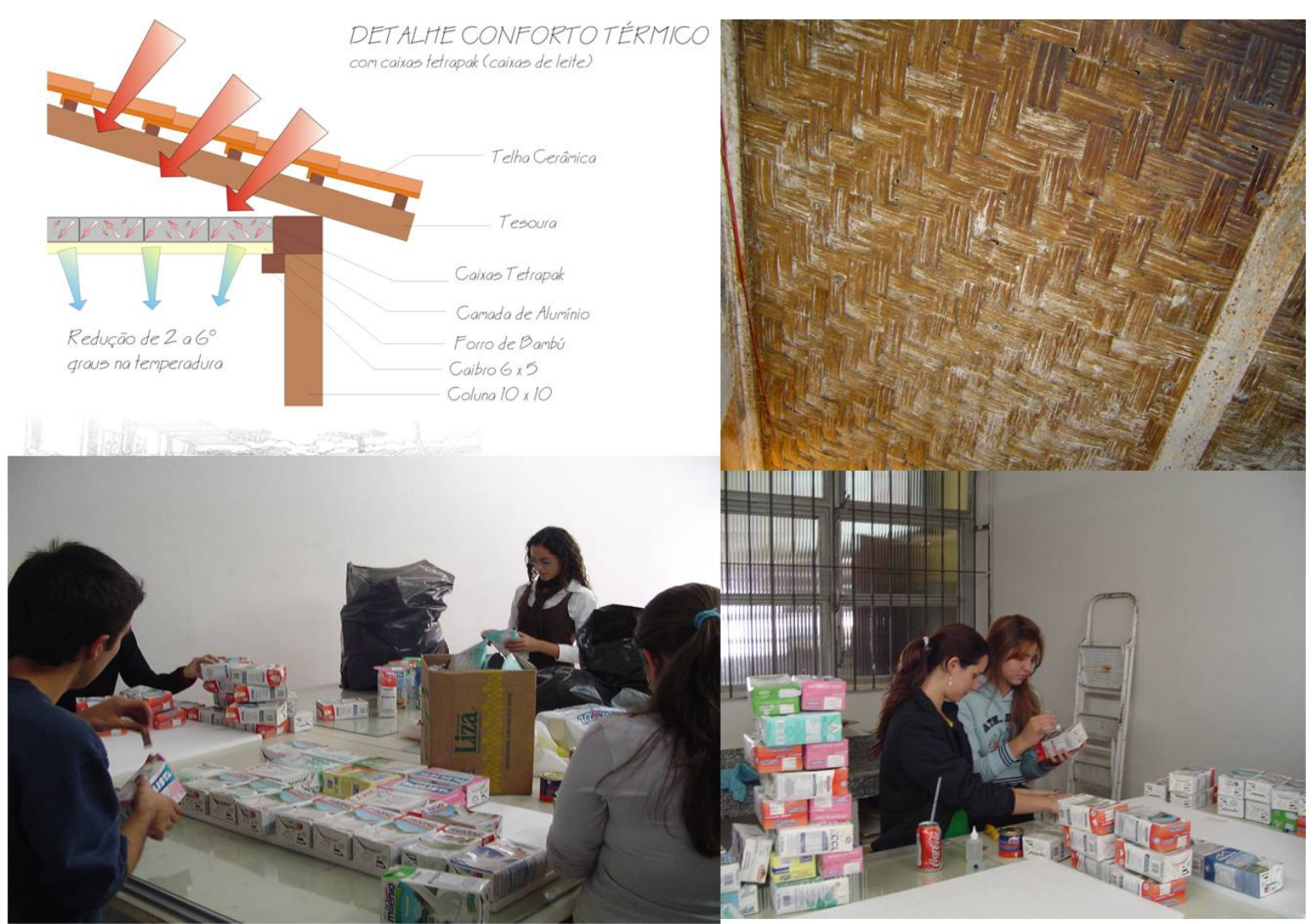

Fig.2.33 O esquema do forro e suas vantagens e o processo de confecção da subcobertura.

Trabalhos como os de VECCHIA E SILVA (2002) e CARLETTO (2005) tratam do tema subcobertura e chamam a atenção para o emprego das caixas de leite tetrapak reutilizadas, em especial no que diz respeito ao desempenho térmico, aspecto que será abordado no capítulo seguinte.

Porém, relativo ao aspecto de facilidade de execução, optou-se por colar as caixas de leite devidamente desinfectadas em solução à base de cloro, limpas e secas em placas de isopor de 10mm. Esta opção foi empregada com o propósito de facilitar posteriores trabalhos de manutenção de instalações nas habitações Xucuru-Kariri.

Antes de serem colocadas nas habitações, as placas para a subcobertura foram preparadas durante atividades acadêmicas realizadas na Maquetaria do Curso de Arquitetura e Urbanismo da PUC-Minas/Poços de Caldas, envolvendo alunos deste curso. Nesta atividade não houve a participação dos índios. 
No que diz respeito à utilização do bambu no forro, verifica-se na mesma fig.2.33 que os Xucuru-Kariri, que executaram o forro apresentado, já conheciam as atividades de trançado e manuseio do bambu. Sendo assim, este potencial não poderia ser desprezado, já que um dos objetivos propostos era conceber uma habitação mais ecológica e sustentável que dialogasse não só com o resgate das tradições construtivas do grupo indígena em questão, mas que também conseguisse promover um melhor condicionamento térmico para seus moradores, empregando materiais naturais e descartados. Ao mesmo tempo, a eleição da esteira de bambu, além de remeter aos conhecimentos indígenas, resgata um emprego comum nas edificações populares e rurais do Brasil colonial, principalmente mineiras.

\subsection{A escolha da terra como material de construção.}

Como já afirmado no primeiro capítulo, a escolha e utilização da terra para as habitações dos índios Xucuru-Kariri reveste-se de significados históricos e identitários, além da vinculação da proposta aos critérios que buscam a qualidade e a sustentabilidade das habitações indígenas.

Como a 'novaterra' é uma tecnologia baseada essencialmente no emprego da terra, bambu e palha de milho, materiais naturais por excelência, faz-se necessário a apresentação de um panorama das tecnologias construtivas de terra que desde tempos remotos vêm sendo empregadas pelos mais longínquos cantos do planeta e, em particular, no Brasil. 


\subsubsection{Aspectos Históricos}

Estima-se que cerca de 40 a 50\% da população mundial ainda nos dias atuais vive em habitações construídas em terra. MILANEZ(1958), Minke(2002), e FARIA(2002), entre outros estudiosos do uso da terra como material de construção, comentavam sobre este fato, certamente desconhecido por muitas pessoas.

Conforme DETHIER (2003), a terra crua se caracteriza como um dos principais tipos de materiais de construção conhecido há cerca de dez mil anos. De acordo com MINKE (2001:13) apud PUMPELLY (1908), "as técnicas de construção com barro datam há mais de 9000 anos". No Turquestão há exemplares de habitações de terra do período de 8000-6000 a.C. Na Assíria, foram encontrados grandes blocos de terra apisionada que datam de 5000 a.C. Uma grande maioria das antigas civilizações utilizou a terra não só na construção de moradias, como também em suas fortalezas e obras religiosas. Há exemplares arqueológicos encontrados por todos os cantos do planeta e, dentre alguns dos mais significativos, pode-se destacar a Grande Muralha da China, que foi construída há 4000 anos. Esta muralha, que pode ser observada na fig.2.34, foi inicialmente foi confeccionada em terra apisionada (tapial) e, posteriormente, foi complementada com pedras naturais e ladrilhos, o que lhe deu, segundo MINKE (2001), a aparência de uma muralha de pedra.
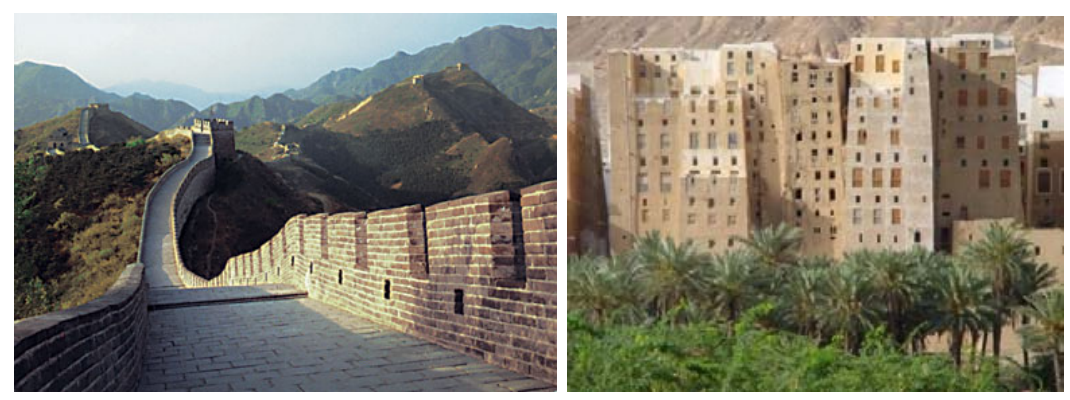

Fig. 2.34. A muralha da China e uma vista do centro histórico de Shibam, no Yemen do Sul: a arquitetura e construção com terra resistindo ao longo da história. 
Outros exemplos significativos são as ruínas históricas de Shibam, no Yemem do Sul, construída no século XV d.C; a Fortaleza de Medinet Habu no Egito, construída há cerca de 3200 anos; a encantadora Mesquita de Djenne, no Mali, África, construída por volta do ano de 800 a.C e reconstruída por volta do ano de 1935; o povoado de Taos, em Pueblos, no Novo México, construído por volta do ano de 1900 d.C., entre muitos outros exemplos que poderiam ser mencionados. Na América do Sul, ganham destaque as ruínas do sítio arqueológico de Chan Chan, no Peru, do Reino Chimu, um vasto conjunto de cerca de $15 \mathrm{~km} 2$ de construções de adobe, que podem ser observadas na fig.2.35.
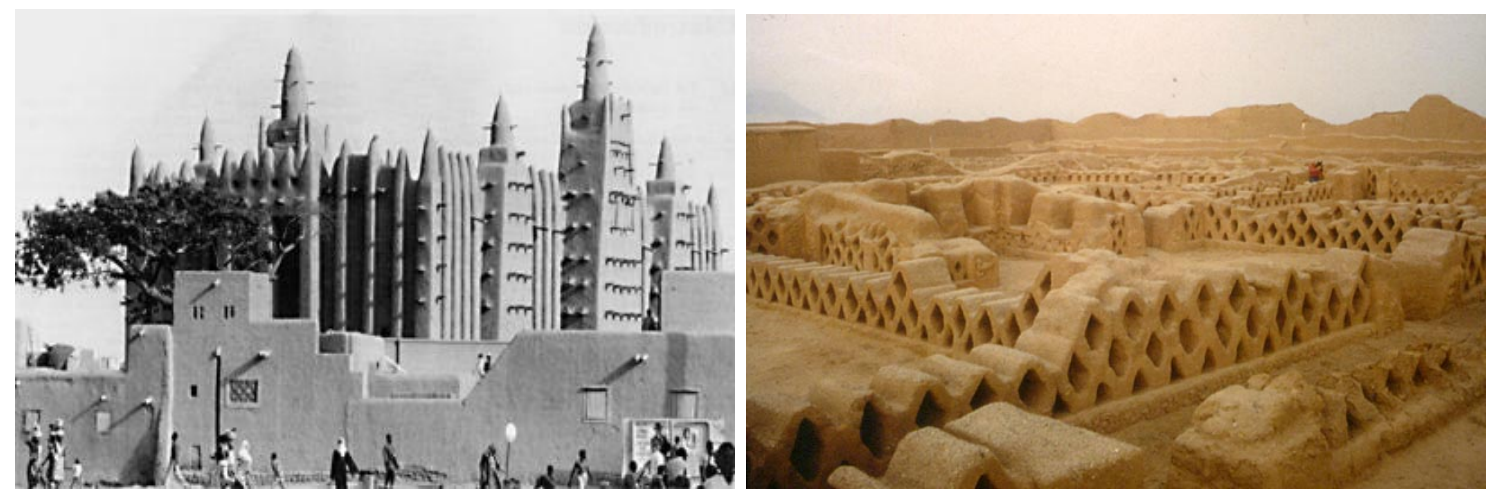

Fig. 2.35. Mesquita de Djenne, no Mali, África, construída por volta do ano de 800 a.C e reconstruída por volta do ano de 1935 do século XX e as ruínas do sítio arqueológico de Chan Chan, no Peru, grandes exemplos da permanência da Arquitetura em terra.

Destacam-se ainda as ruínas do sítio pré-colombiano de Tihuanaco, na Bolívia, edificadas por volta do ano 1200 a.C, entre os importantes exemplares latinoamericanos de construções com terra, como pode se observar na fig. 2.35a. 


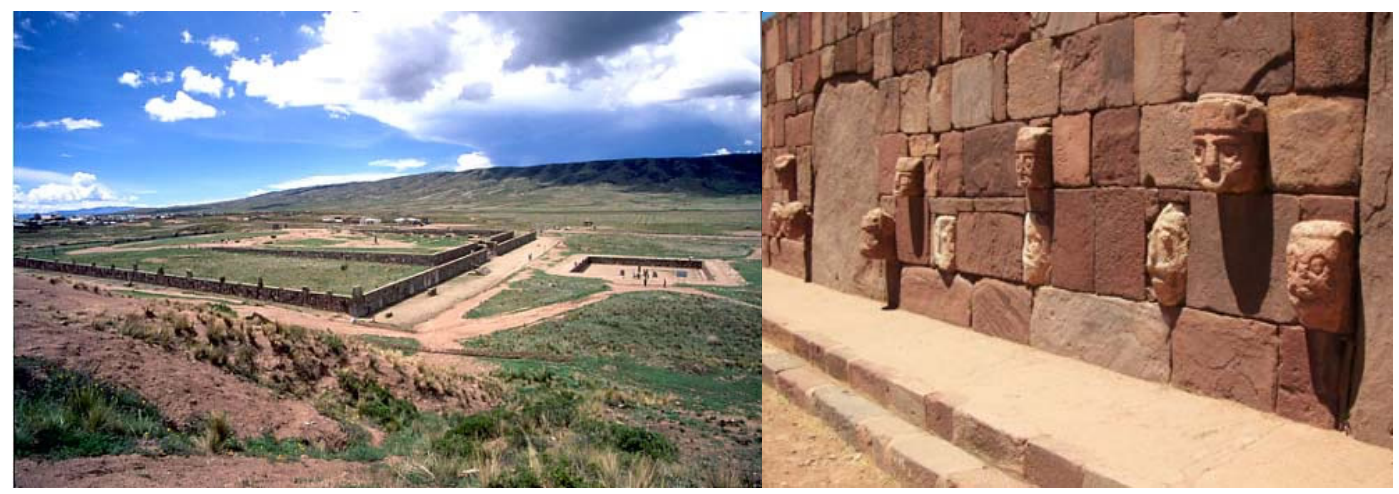

Fig.2.36a.O sítio arqueológico de Tihuanaco, na Bolívia e os blocos de adobe com o destaque para as esculturas também em terra.

Como já apontado no presente trabalho e comentado por vários autores, é importante reforçar que tais tecnologias assumem, de acordo com a região, cultura e país onde forem implantadas, denominações diversas.

Na fig.2.36a, apresenta-se uma adaptação do interessante de um diagrama utilizado por FERNANDES (2006), adaptado do original do grupo CRATerre, disponibilizado por HOUBEN e GUILLARD (1989). De tal diagrama foram selecionadas e destacadas através de cores as tecnologias de terra conhecidas e praticadas em alguns locais do Brasil ainda hoje.

Observando-se a fig.2.36a, é possível perceber que, embora a denominação varie daqueles mais corriqueiras, as tecnologias de terra conhecidas no Brasil são aquelas destacadas primeiramente sob os $n^{0}$ s 5 , aTaipa de Pilão; $n^{0} 6$, os blocos apiloados (uma variante dos adobes); $n^{07}$, os Blocos de Terra compactada ou BTCs e o $\mathrm{n}^{\circ}$ 8, denominados como blocos cortados. Os itens de n's 11 e 12 correspondem aos adobes propriamente ditos e os nos 14 e 15 correspondem à chamada taipa de mão ou pau-a-pique. 


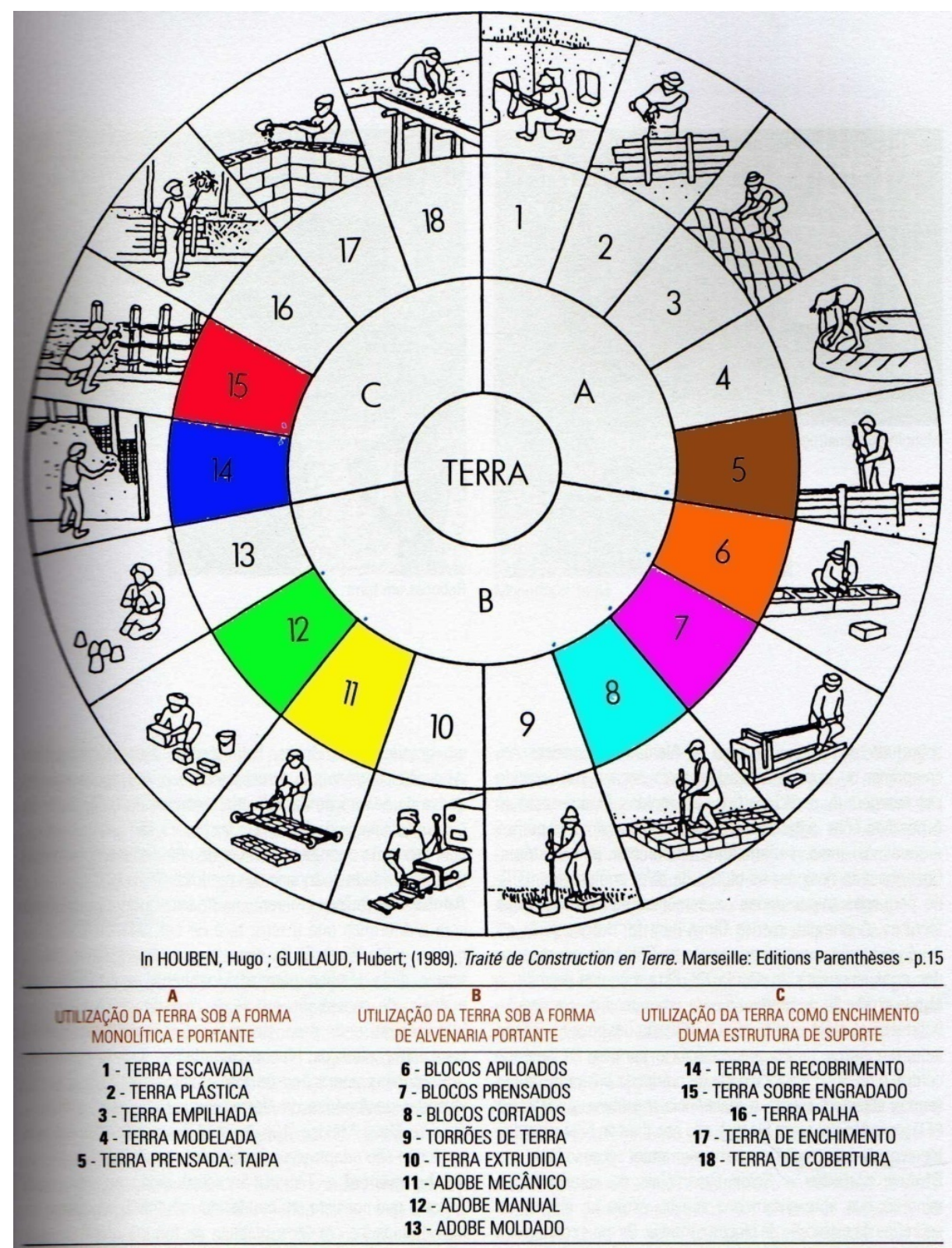

Fig.2.36a. FERNANDES,M. Diagrama estabelecido pelo CRATerre, cedido por HOUBEN e GUILLAURD.

Há diversos documentos que comprovam a existência de edificações em que o emprego da terra crua remonta o período colonial. Esses exemplares estão espalhados por todo o país. Dentre eles, destacam-se a Casa Bandeirista do Sítio do Padre Inácio, em Cotia- SP; a Igreja Matriz de Pirenópolis- GO, construída em taipa de pilão, e a Matriz de Nossa Senhora do Ó de Sabará-MG, observadas através da fig.2.36b, todas construídas durante o séc. XVIII. 

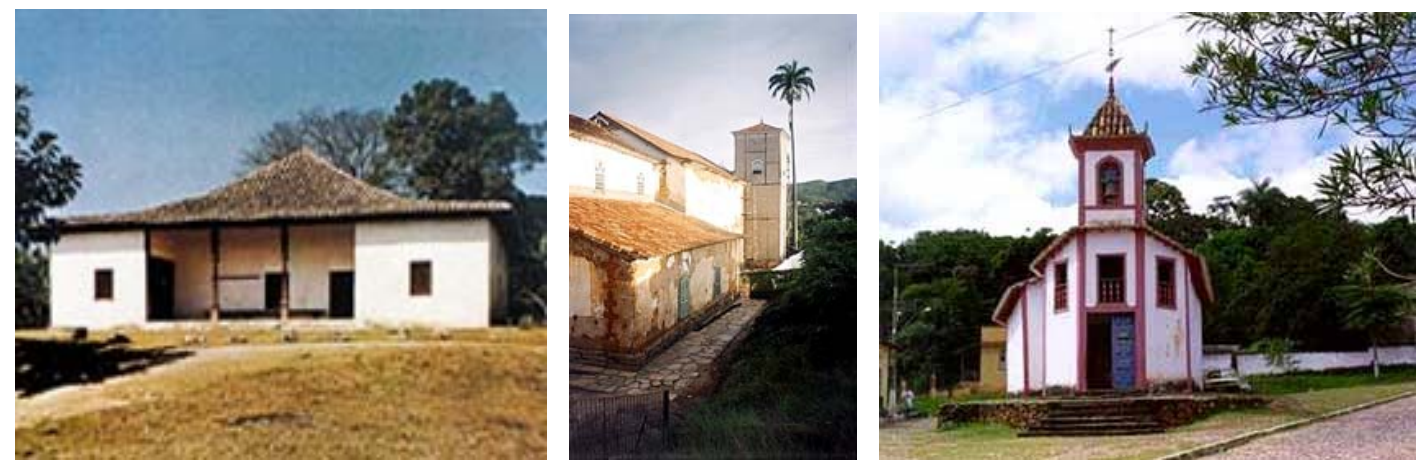

Fig. 2.36b. A Casa Bandeirista do Sítio do Pe. Inácio, a Matriz de Pirenópolis-GO e a Igreja Matriz de Nossa Senhora do Ó, em Sabará-MG, exemplares históricos brasileiros de construções com terra.

Além das inúmeras igrejas, há um expressivo número de sedes de fazendas dos Ciclos da Cana-de-Açúcar e do Café construídas entre os séculos XVIII e XIX, dentre as quais se destacam a Fazenda Milhã, perto de Piracicaba-SP, construída entre 1845 e 1850 e a Fazenda Pau D’Alho construída em São José do Barreiro-SP em 1818, observadas na fig.2.37, e esta última, edificação que, de acordo com Lemos (1999:139) é "sempre lembrada como estabelecimento pioneiro do café, mas não passa de casa mineira corriqueira, sede de modesto engenho de pinga, que em época não sabida foi ampliada, recebendo em toda a sua volta dois alpendres e salas que vieram dar a ela outro conforto que as primitivas instalações de 1818 não propiciavam".
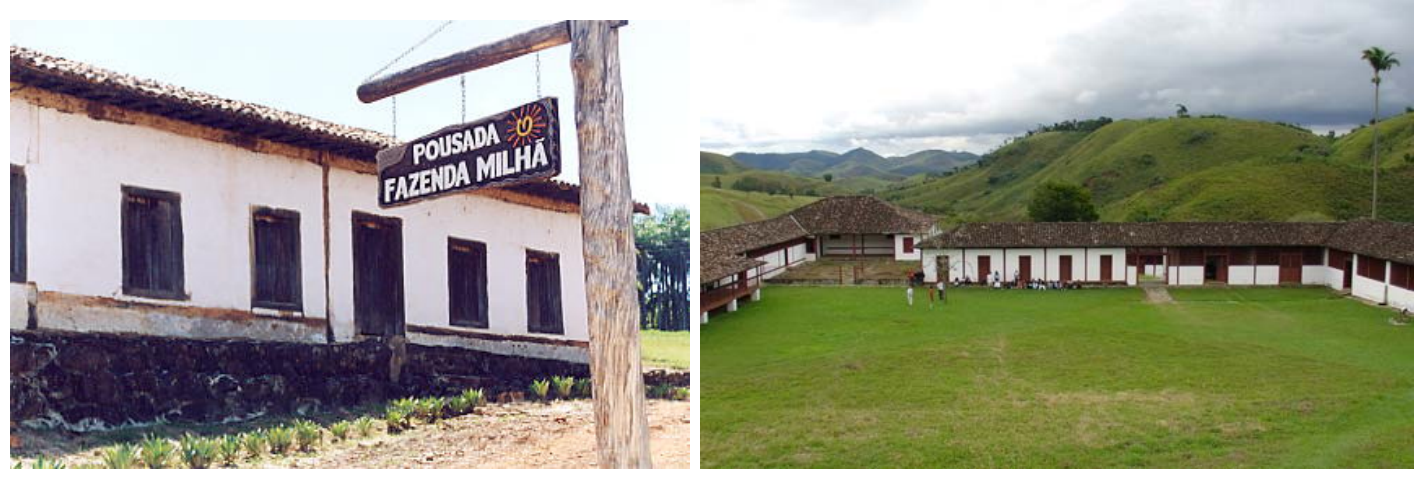

Fig. 2.37. Faz. Milhã, Saltinho, Piracicaba e a sede da Fazenda Pau D' Alho, no Vale do Paraíba, ambas no Estado de São Paulo. 
De acordo com DI MARCO (1984) "taipa, pise de terre, rammed earth, adobe, adobón, adobito, pau-a-pique, wattle and daub, mus and wattle, torchis, quincha, terroni, tapia, cob... sob os mais diversos nomes e alheia a toda essa briga, desde o Neolítico até hoje, a terra tem sido utilizada há séculos para edificar residências, palácios, pirâmides, muralhas, estufas, igrejas, etc".

$\mathrm{Na}$ atualidade podem ser encontradas construções interessantes em que há o emprego da terra como material de construção, em várias partes do mundo.

Merecem destaque, como se verifica na fig.2.38, entre tantos projetos e obras: a Casa Ecológica de Sverre Fehn na Suíça, construída em 1991 e 1992, com a participação da arquiteta brasileira Letícia Acchar e a inovadora 'quincha metálica' do arquiteto chileno Marcelo Cortés, destacando entre suas obras a Granja Aventura e a Casa Peñalolen, construídas respectivamente no ano de 2006.

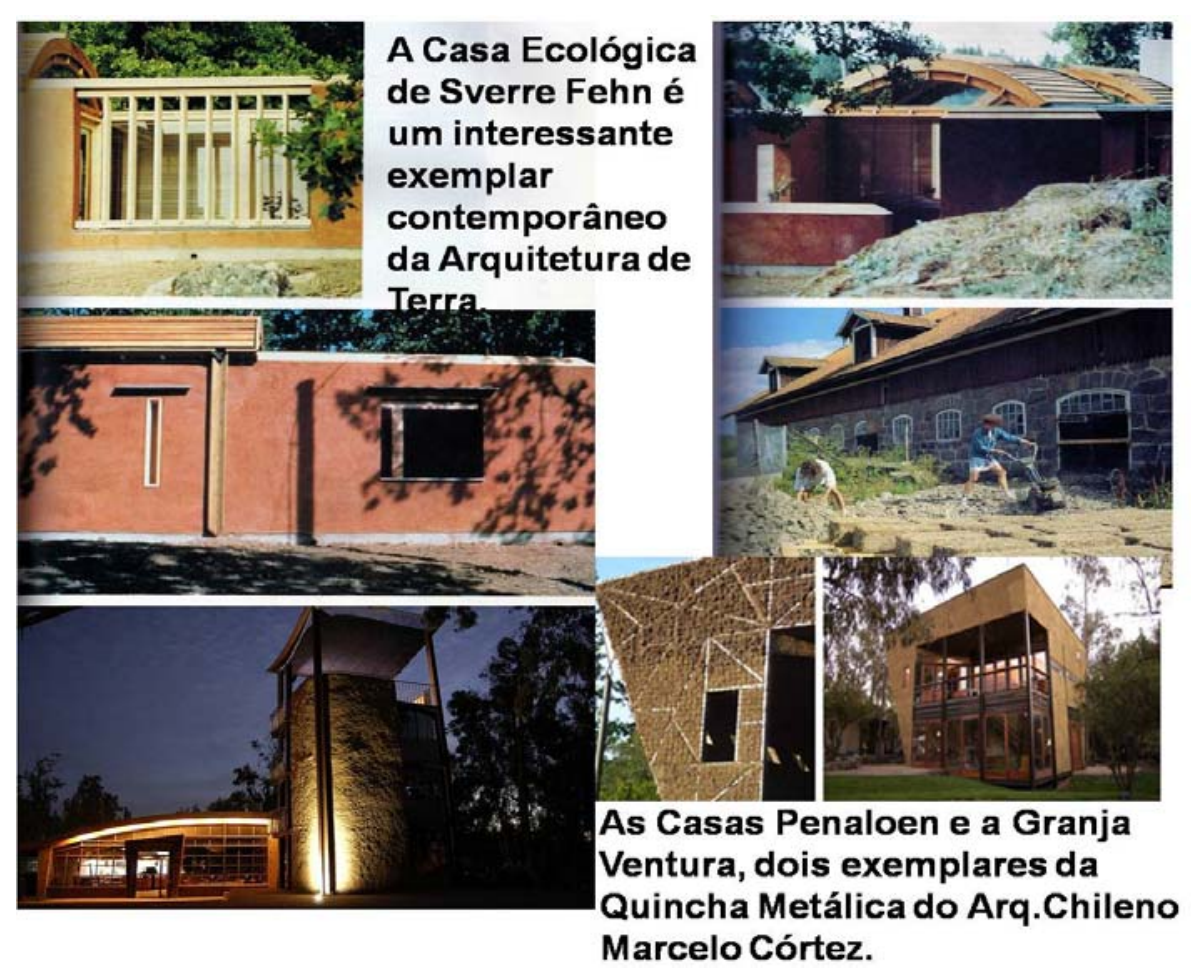

Fig.2.38. A Casa Ecológica de Sverre Fehn (imagens superiores), a Casa Penaloen (lado esquerdo) e a Granja Ventura (lado direito) obras do arquiteto chileno Marcelo Cortéz. 
Hoje no Brasil há também belas construções a serem apresentadas, como as casas edificadas em 1986 em Itaipu, Niterói-RJ e a casa de Itamaracá, em Pernambuco, obras do escritório carioca Cydno da Silveira \& Gama (C.S.A. Arquitetura). Ao mesmo tempo, devem ser citadas as interessantes propostas de residências construídas ou reformadas pelos arquitetos Marcos 'Reco' Borges Rezende e Raymundo Rodrigues em Tiradentes-MG entre 1993 e 2003, ganhando destaque um Refúgio de Hóspedes, lá construído em adobe, que podem ser melhor observados na fig.2.39.

Ainda que não sejam muito conhecidas, tais obras materializam as qualidades e potencialidades que a utilização da terra como material sustentável possibilita nos dias atuais.
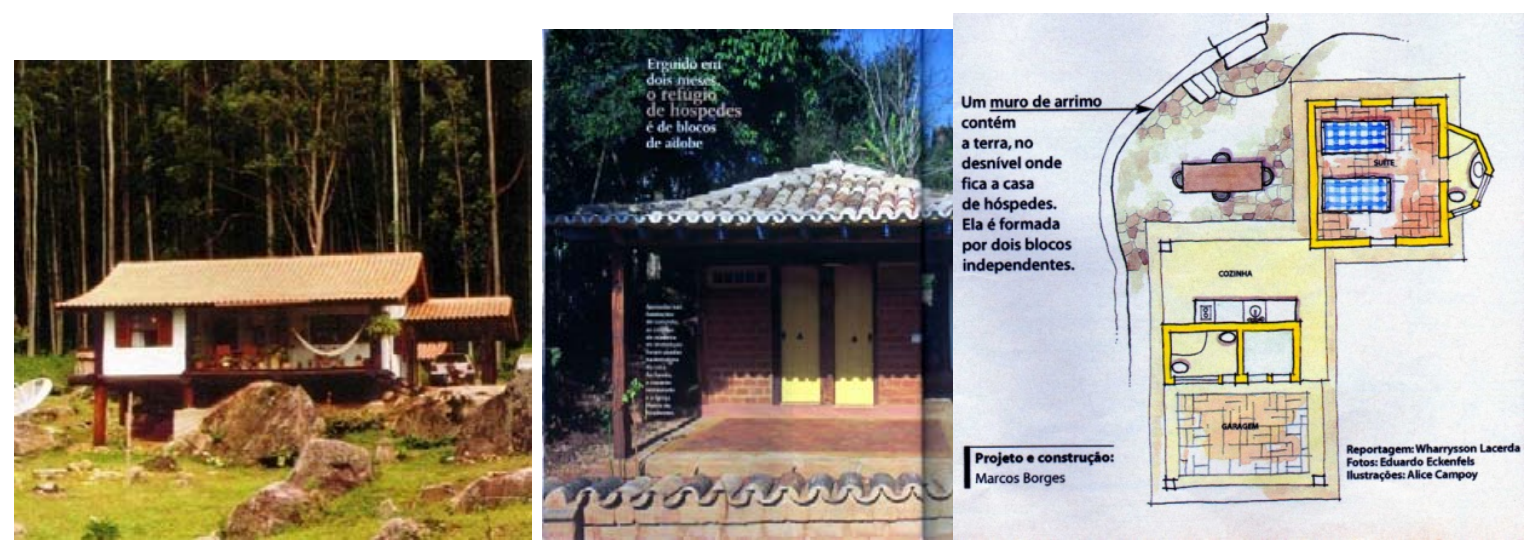

Fig.2.39. A Casa de Itamaracá-PE de Cydno da Silveira e Amélia Gama e o Refúgio de Hóspedes de Marcos (Reco) Borges, em Tiradentes-MG, dois bons exemplos da arquitetura brasileira em terra.

No entanto, é importante refletir sobre o atual emprego da terra como material de construção no Brasil que, em direções opostas, consolida-se através da reprodução da taipa de mão ou pau-a-pique com o 'selo-estigma' de material barato e tecnologia dos pobres ou nas belas residências anteriormente mencionadas projetadas por arquitetos brasileiros que, via de regra, atendem um 
seleto grupo disposto a pagar altos preços por propostas arquitetônicas, ecológicas e sustentáveis.

\subsection{As técnicas de construção com terra introduzidas no Brasil desde o período colonial.}

As técnicas de construção com terra conhecidas e empregadas no Brasil, conforme o legado da colonização portuguesa são a taipa-de-pilão, a taipa de mão ou pau-apique (que em Portugal é conhecida como tabique) e o adobe, popularmente conhecido como tijolo cru. Variando de região para região, algumas dessas técnicas foram mais difundidas e tiveram melhor aceitação, enquanto outras entraram em desuso.

Porém, de forma geral, há ainda hoje práticas diversas em plena utilização, mesmo que, infelizmente, haja resistência ou preconceito quanto ao emprego da Arquitetura e construção com Terra ${ }^{27}$ no país. Na fig. 2.36a apresentada anteriormente pode ser observada a grande variedade de sistemas de construção antigos e modernos espalhados pelo mundo.

\footnotetext{
${ }^{27}$ Não há uma única definição para Arquitetura de Terra. O CRATerre, na intenção de organizar o conhecimento, criou os termos arquitetura em terra (casa escavada - construção troglodita); arquitetura de terra (terrón, adobe, taipa de pilão, etc); e arquitetura com terra (técnicas mistas taipa de mão, torta, etc.). De acordo com Célia Neves, Coordenadora Internacional do Proyecto de Investigacion XIV.6 "PROTERRA"- CYTED/HABYTED esta classificação não Ihe agrada. A Engenheira não acredita ser necessária esta distinção e não concorda com o uso de preposições para isso, principalmente pela dificuldade de tradução para outros idiomas. Comenta ainda que no PROTERRA, adotam o termo Arquitetura e Construção com Terra pois assim cobrimos todas as atividades: desde a criação até a execução, inclusive a restauração. Após muita discussão (e alguns ainda não aprovam esta posição do PROTERRA), e por ter verificado a tendência de arquitetos denominarem Arquitetura de Terra e engenheiros denominarem Construção com Terra para o mesmo assunto, os membros do PROTERRA chegaram a um "acordo" em tratar a tecnologia como Arquitetura e Construção com Terra. Este termo inclui a criação, os projetos, as técnicas construtivas os procedimentos de seleção de solos, controles de execução, especificações e normas, testes expeditos e ensaios de laboratório. (Resposta da Eng. Célia Neves enviada por e-mail em 24/08/2005).
} 
Na seqüência, são apresentadas as tecnologias caracterizadas como aquelas que, no Brasil, foram ou são amplamente conhecidas.

2.12.1. Os adobes. De acordo com CORONA \& LEMOS (1972) "adobe é um paralelepípedo de barro de grandes dimensões, que difere do tijolo por não ser cozido ao forno. De barro cru, seco à sombra e depois, ao sol, é composto de argila e areia em pequena quantidade. Ao barro pode ser misturado estrume ou fibra vegetal, ou ainda crina, com a finalidade de se obter maior consistência nos blocos". Podem ser argamassados com barro e devem ser revestidos com massa de cal e areia ou terra, cal e areia. Existem as variantes morfológicas adobo ou adoba. $\mathrm{O}$ termo é de origem árabe, attobi. Porém, dá-se também o nome de adobe ou adobo ao seixo rolado dos rios.

Em alguns locais, podem receber a denominação de tijolos crus ou tijolos burros. Para JONES (2003), designa-se por adobe o bloco de forma regular de argamassa de barro 'ordinário' amassado com areia e palha, ou com fibras vegetais, colocado em forma de tijolo e, depois de desenformado, seco ao sol, como se observa na fig.2.41.
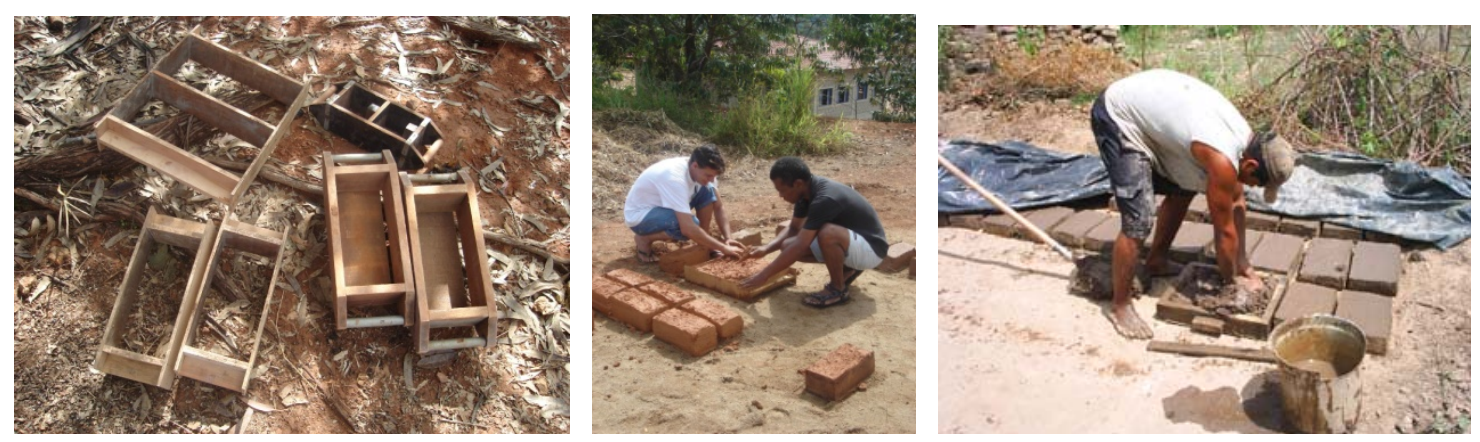

Fig.2.41.Exemplos de fôrmas para a produção de adobes, desforma de adobes e secagem ao sol. 


\subsubsection{A técnica construtiva com a utilização de adobes.}

De acordo com o mesmo autor, as paredes de adobe poderiam ser construídas segundo as mesmas regras utilizadas para paredes em que há o emprego do tijolo cozido, com a particularidade de que seu emprego na atualidade estar apenas vinculado às construções pobres, ou aos locais de terreno arenoso, onde o acesso de outros materiais pode ser mais difícil. Este tipo de construção, apesar de ser uma das técnicas mais antigas existentes no mundo não tem um uso disseminado no Brasil. Porém, na região de São João del Rey- MG, localiza-se no pequeno município de Prados, o distrito de Valeriano Veloso, mais conhecido por "Bichinho", que está resgatando a tradição da produção de adobes através de pequenas olarias familiares, que comercializam o produto diretamente com os consumidores.

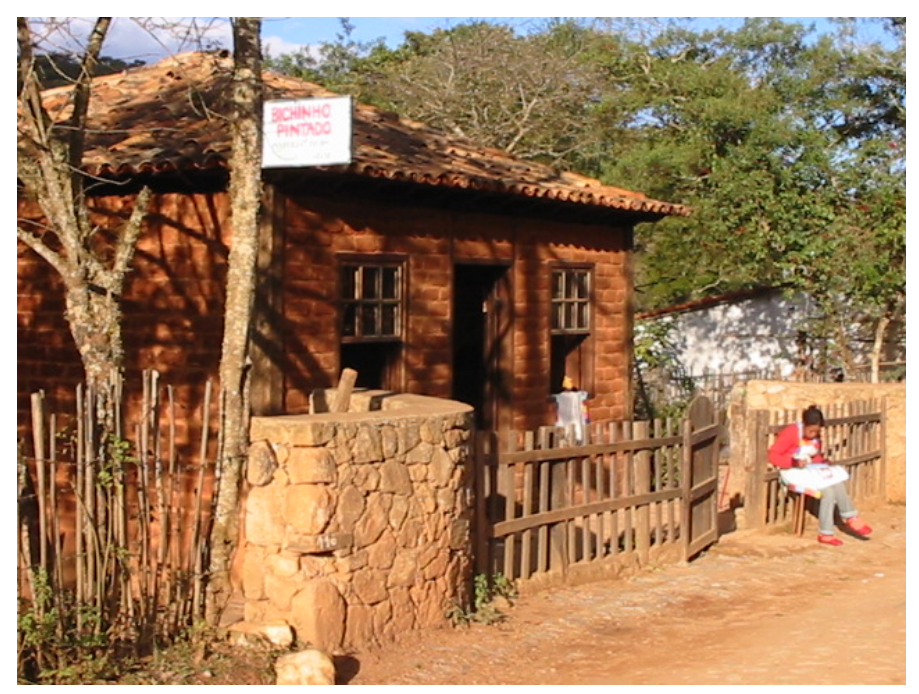

Na fig.2.42. se observa uma construção de adobe do Bichinho, Distrito de Valeriano Veloso-MG . A moldagem dos blocos é feita com uma fôrma de madeira rudimentar, normalmente construída pelo oleiro no próprio local, denominada adobeira. As espessuras das paredes nas construções em que se empregam os adobes são em média de 25 a $35 \mathrm{~cm}$ de largura. Alguns inconvenientes: tais blocos possuem a vulnerabilidade de, eventualmente, serem atacados por roedores e serem pouco estáveis aos 
movimentos sísmicos, assim como são frágeis quando submetidos a esforços laterais provocados pela influência das cargas da cobertura. Para compensar essas fragilidades, as estruturas de adobe mais antigas eram, em alguns casos, reforçadas com a introdução de contrafortes. O adobe deve ser rebocado e tratado preferencialmente com rebocos à base de cal hidratada ou por intermédio de uma caiação (pintura com cal diluída) diretamente sobre as paredes, com a intenção de protegê-las das ações atmosféricas, principalmente da água. Por ser facilmente degradado pela água, só pode ser executado sobre fundações de concreto, de alvenaria de tijolos cozidos impermeabilizados ou de pedra comum, geralmente do tipo do xisto, sobre uma camada erguida com cerca de $60 \mathrm{~cm}$ acima do solo, a partir da qual se dá início a construção das paredes, evitando-se assim a umidade ascendente.

2.12.2. A taipa. Taipa é o nome genérico que se costuma dar a todo sistema construtivo em que se emprega, na confecção de paredes e muros de fechamento, a terra umedecida ou molhada, apiloada dentro de engradamento de madeira ou bambu. Não se trata de alvenaria de terra ou barro, como no caso do adobe. Tratase de um sistema em que os panos contínuos de parede são executados diretamente no local, em que a terra não sofreu nenhum beneficiamento anterior. Existem dois tipos de taipa: a taipa de pilão e a taipa de mão, também conhecida como taipa de sebe ou ainda, de sopapo ou simplesmente, pau-a-pique. Uma vez que a taipa de mão ou pau-a-pique são a base da nova tecnologia construtiva utilizada nas habitações dos índios Xucuru-Kariri, como abordado no primeiro capítulo, trata-se a seguir da taipa de pilão. 
2.12.2.1. Definição e a técnica construtiva da taipa de pilão. O uso da taipa de pilão é remoto. Parece ter sido empregado em tempos imemoriais no Oriente, trazido até o Brasil pelos colonizadores portugueses. No período em que os árabes que dominaram Portugal, a taipa de pilão foi lá disseminada, embora esta tecnologia construtiva já fosse do conhecimento dos romanos que habitaram a região ${ }^{28}$.

Em síntese, a parede de taipa de pilão é concebida comprimindo-se a terra dentro de fôrmas de madeira. As fôrmas de madeira, ou taipal (às vezes denominado tapial), são constituídas de duas grandes pranchas compostas de tábuas emendadas pelo topo, que se mantém de pé e afastadas entre si graças a sistemas variáveis em que são empregados pontaletes, travessas ou grampos.

Sobre a técnica construtiva da taipa-de-pilão pode-se dizer que, como a parede é confeccionada entre fôrmas de madeira, à medida que o trecho de parede vai ficando pronto, depois de seca a terra, o taipal é retirado. A taipa-de-pilão dá origem a grandes blocos cujas medidas decorrem das medidas dos taipais. Em Portugal e no Brasil colonial, a espessura média das paredes de taipa era de $60 \mathrm{~cm}$, embora possam ser encontrados exemplos cuja espessura das paredes varie entre $30 \mathrm{~cm} \mathrm{e}$ 1.50m. Há autores que afirmam que a terra apropriada para a taipa de pilão é a terra vermelha, uniforme, sem vestígio de matéria orgânica e com grande umidade natural, não muito agregada nem muito arenosa, de modo que, se apertada nas mãos, origina um bolo compacto mostrando os sulcos dos dedos. Porém, conforme o documento publicado pelo PROTERRA (2005), denominado "Seleção de Solos e Métodos de Controle em construções com terra - Práticas de Campo," há uma série de recomendações que podem ser úteis tanto para a definição do melhor tipo de

\footnotetext{
${ }^{28}$ Dentre exemplares portugueses que merecem destaque onde ocorreu o emprego da taipa está o sítio arqueológico de Conímbriga, nas imediações da cidade de Coimbra.
} 
terra para cada tecnologia construtiva quanto para a correção do solo disponível, quando não houver possibilidade para se conseguir um outro tipo de terra para a execução da obra.

Eventualmente, incluem-se na espessura da taipa de pilão peças longitudinais de madeira que podem ser empregadas para reforçar a taipa.

Podem ser encontradas algumas definições um pouco distintas daquelas ora utilizadas, assim como pode haver controvérsias entre as mesmas. Entretanto, o que mais interessa a esta pesquisa são as variações das tecnologias construtivas de terra que foram empregadas no Brasil desde o período colonial.

\subsubsection{A taipa de mão ou pau-a-pique: antecedente da 'novaterra'.}

De acordo com DI MARCO (1984) e LOPES (2003), a taipa de mão, de sopapo, de sebe, barro armado ou pau-a-pique consiste de uma 'ossatura' de madeira ou de bambu, formada por ripas horizontais e verticais amarradas com tiras de couro, cipó, barbante, prego ou arame, preenchida com uma mistura de terra, água e fibras. Estes elementos, juntamente com as peças portantes de madeira, formam a parede da edificação. Após a secagem do barro, é aplicado o reboco (que pode ser constituído essencialmente de terra) e, posteriormente, a pintura ${ }^{29}$.

\footnotetext{
${ }^{29}$ Tanto o reboco quanto a pintura, quando se tratam das tecnologias de terra, podem empregar em sua constituição a terra, fibras naturais, e no caso da pintura, alguns pigmentos extraídos da variação da própria cor dos diversos solos, assim como o emprego de pigmentos químicos como óxido de ferro ou de cobre. No entanto, dependendo do local onde a edificação será construída e para que finalidade, assim como da aceitação e da facilidade para a obtenção (ou não) desses materiais, algum percentual de cimento pode ser empregado à argamassa de reboco, lembrando que, tal procedimento pode alterar o comportamento da edificação no que diz respeito às intempéries e variações térmicas.
} 
Referências encontradas na obra de SMITH (1955) e MILANEZ (1958), são contraditórias no que diz respeito ao emprego da taipa de mão no Brasil. O primeiro autor afirma que, quando os portugueses chegaram ao Brasil, acabaram encontrando exemplares de habitações indígenas onde havia o emprego da terra, junto com madeira e palha. Porém, MILANEZ (1958) afirma que "antes da chegada dos portugueses, os índios não usavam a terra para construir: seus abrigos eram de madeira, paus roliços, vedações de palha e folhagens" ${ }^{30}$.

Esta descrição combina com os relatos de Hans Staden e Paul Gaffarel abordados no primeiro capítulo deste trabalho. Além dos portugueses, também os africanos trazidos ao Brasil como escravos possuíam conhecimento do emprego da terra nas construções. Conforme lembra LOPES (2003) "muito utilizada em construções rurais, a taipa de mão foi também usada em áreas urbanas, tanto em paredes externas quanto nas internas. Era comum seu uso associado a outras técnicas, sendo as paredes externas construídas de adobe ou taipa de pilão e as divisões internas e paredes do piso superior construídas com esta técnica por ser um material mais leve". A mesma autora afirma que, atualmente, observa-se que a taipa de mão, mesmo ainda sendo uma técnica de uso corrente em quase todo o território brasileiro, utilizada desde os primórdios da colonização e fortemente integrada à cultura brasileira, principalmente à do caboclo da zona rural, encontra-se em desuso,

\footnotetext{
${ }^{30}$ Em entrevista concedida à Gabriel Rodrigues da Cunha em 2006 , na Revista Virtual Vitruvius, o Prof. Júlio Roberto Katinsky afirma "Então a minha preocupação quando eu comecei a me interessar por habitação e, aí é importante porque isto está em discussão até hoje, quando eu comecei a me interessar fiz uma tese de doutorado sobre a casa bandeirista ("A casa bandeirista - nascimento e reconhecimento da arte em São Paulo". A proposta inicial deste livro era a de estudar a hipótese "casa paulista" como resultado da junção da casa portuguesa e da indígena. Posteriormente, seis meses depois, considerou que esta hipótese era óbvia, se propondo a estudar, portanto, como havia sido descoberta esta hipótese. Assim a tese ficou com o subtítulo "nascimento e reconhecimento da arte em São Paulo"). Lá eu tentei mostrar que a casa bandeirista era uma associação de um espaço europeu, português e popular e o espaço indígena. E eu não consegui achar o nexo entre a casa popular portuguesa e a casa indígena, na minha tese. Eu afirmei isso e mostrei que era possível, mas não demonstrei. Mas anos depois, lendo um livro de um antropólogo americano, eu descobri o elo entre a casa popular e a oca indígena e por sua vez a associação, digamos assim, a associação entre os dois, na casa bandeirista. Mas aí eu percebi que o processo era maior! (A íntegra desta entrevista esta disponível em:

< http://www.vitruvius.com.br/entrevista/katinsky/katinsky 2.asp >. acesso em: 02mai.2008)
} 
pois ela é associada a construções pobres e transitórias.Tal afirmação pode ser constada na fig.2.43, através de exemplares de casas periféricas de Maceió e Marechal Deodoro, no estado de Alagoas.

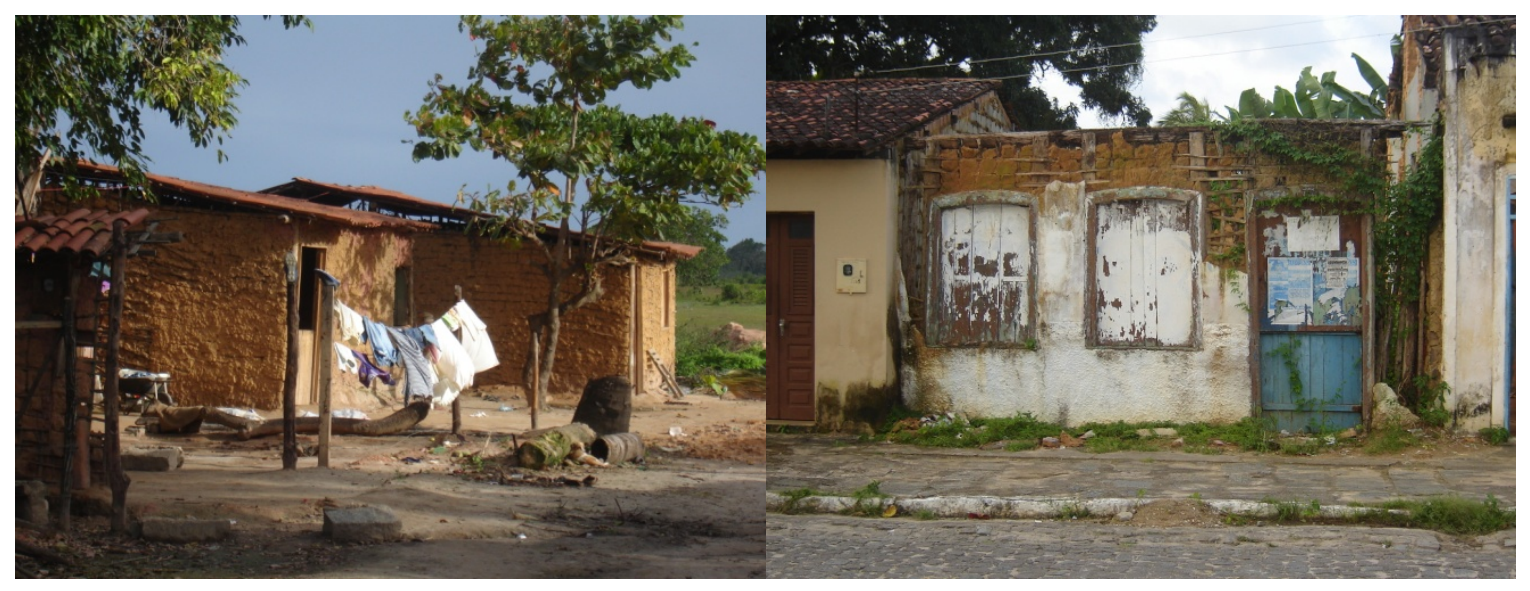

Fig. 2.43. Casas em taipa de mão ou pau-a-pique na periferia de Maceió e Marechal Deodoro-AL.

Para ALVARENGA (1995) apud LOPES (2003), "a visão de solução provisória para a construção de habitações em taipa decorre da questão que se constrói com esta técnica, na esperança de, em breve, se construir com alvenaria de tijolos. Assim, as construções são edificadas sem as devidas recomendações técnicas e, além do aspecto visual, aquele relativo à higiene fica comprometido, dentre outros fatores, pela falta de acabamento, estabelecendo-se, por conseqüência, a idéia de que a casa de taipa está vinculada à pobreza e às habitações provisórias e insalubres".

Coincidentemente, quando durante esta pesquisa se visitou a Fazenda Canto, localizada no município alagoano de Palmeira dos Índios, área de onde se originaram os índios que hoje se encontram afixados em Caldas, através da imprensa local, deparou-se com notícia na Tribuna do Sertão, de 17 de julho de 2006, a respeito da campanha para erradicação das casas de taipa de mão em Palmeira dos Índios. Conforme descrevia a reportagem, apresentada junto nos 
anexos, a demolição das casas de taipa se mostrava como a melhor forma de minimizar os problemas relativos à Doença de Chagas, uma vez que estariam comprometendo a saúde dos moradores por causa da possível presença, decorrente do mau emprego e conservação da tecnologia, de focos de 'barbeiros'. O que tais notícias não levam em consideração, ainda que a preocupação diga respeito ao aspecto da saúde da população, é que a destruição de casas de taipa, ao invés das campanhas de orientações e incentivo para sua correta conservação e manutenção, reforça o processo de apagamento das matrizes construtivas coloniais que, em última análise, poderiam se constituir como exemplares- referências da memória e identidade construtiva brasileiras.

Salienta-se que a concepção de habitação parte, naturalmente, da forma de abrigo. A evolução das habitações ao longo da história da humanidade segue o processo de adaptação dos povos ao ambiente natural e foi essa relação que, de acordo com OLGYAY (1963), determinou a forma de construir, as tipologias de construção e o uso dos materiais construtivos.

Reforçando esta tese, segue na fig. 2.44 a imagem de outras duas casas bandeiristas construídas em terra no século XVIII, conservadas até hoje como referência das Entradas e Bandeiras ocorridas no Brasil, entre os séculos XVI e XVIII.

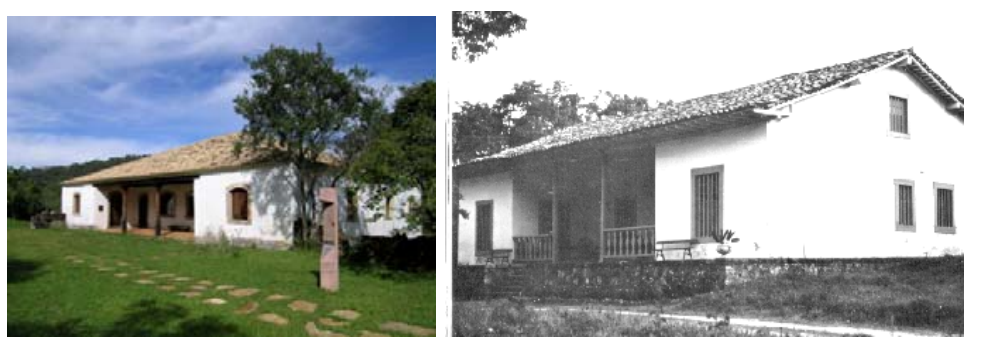


Fig.2.44 : A Casa Bandeirista da Fazenda do Manso, próxima do Pico do Itacolomy, na região de Ouro Preto-MG e a sede da Fazenda Pau-Dalho, entre Indaiatuba e Itu-SP, dois exemplares históricos em que ocorreu o emprego da terra.

\subsubsection{A estrutura e materiais empregados na taipa de mão no Brasil}

O processo de execução de paredes de taipa de mão ou pau-a-pique ainda que apresente algumas diferenças, essencialmente começa com o levantamento de toda estrutura principal de paredes, seu travamento e em seguida colocação da estrutura de telhado e cobertura. Somente depois de coberta a edificação é que começa o barreamento para enchimento dos vãos. Depois do barreamento pode vir uma sobrecapa de barro ou de barro agregado à areia e cimento, utilizada como reboco e posterior caiação. Em alguns casos pode-se observar a caição diretamente aplicada sobre a taipa de mão ou pau-a-pique.

A grande potencialidade desta tecnologia diz respeito ao preenchimento do entramado ou ossatura que serve de suporte ao barro: em todo Brasil é possível encontrar variações do entramado em que há o emprego de madeiras roliças de variadas espessuras, de bambu em meia cana, de tiras de bambu trançadas, lembrando uma esteira, ou bambus inteiros e ainda troncos de palmeiras ou palmáceas diversas, entre os materiais mais encontrados. No entanto, há também exemplos em que a ossatura de madeira ou bambu tenha sido substituída por malhas de ferro galvanizadas.

Os materiais que compõem a ossatura e o entramado são amarrados com buritis, sisal, tiras de couro ou plástico, arame ou ainda presos por pregos. Após a execução desta estrutura ou ossatura é que tem início o barreamento, etapas que podem ser 
observadas na fig.2.45. De acordo com Lopes (2003), "na preparação da mistura da argamassa de preenchimento, utiliza-se, em algumas regiões, apenas a terra com água, enquanto que em outras, são acrescidos alguns materiais como fibras vegetais, palha, esterco de gado, cal ou cimento, que funcionam como estabilizantes contribuindo para diminuir a retração ou aumentar a resistência. A terra do próprio local pode ser empregada sem muita restrição ao seu tipo". De acordo com o já mencionado Manual de Seleção de Solos do Proterra conforme aponta NEVES et al (2005), "os testes apresentados são perfeitamente credenciados para selecionar solos apropriados e, em conjunto com o conhecimento técnico do especialista, para projetar e acompanhar a obra, garantir o desempenho e a durabilidade da "casa de terra"."

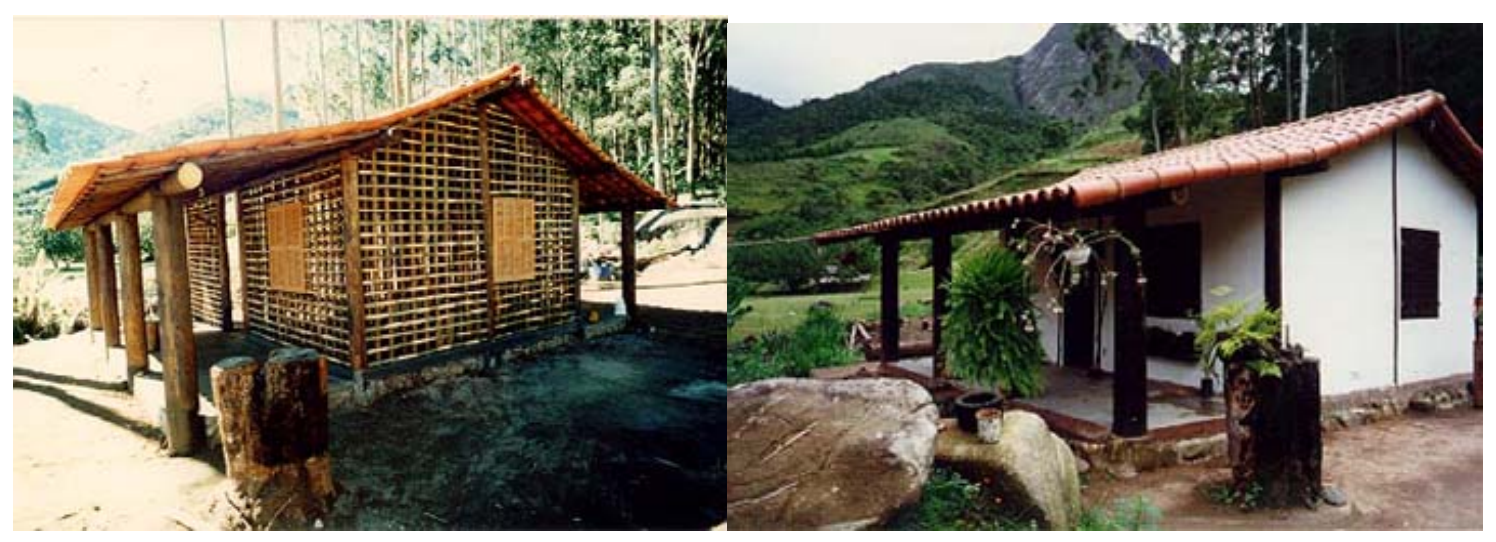

Fig.2.45. A estrutura do esqueleto e entramado já coberta deste bangalô contemporâneo do Arq. Cydno da Silveira, e depois, a mesma casa já preenchida, alisada e caiada configura-se como um exemplo interessante da adoção da taipa de mão, talvez a mais simples das tecnologias de terra existentes no Brasil desde o período colonial.

\subsubsection{A 'novaterra' como solução local.}

Quando se chegou à conclusão de que a adaptação da taipa de mão e do bajareque mejorado seria uma boa alternativa para os Xucuru-Kariri remanejados, esta decorria principalmente da razão de se ter certificado que os índios conheciam e utilizavam 
amplamente a taipa de mão em suas moradias há muitos anos. Outro motivo era o fato de se ter conhecimento de que tanto a FUNAI, como a FUNASA e as Secretarias de Saúde no Nordeste por vezes "incentivavam" a substituição deste sistema construtivo por alvenaria convencional, tentando, assim, diminuir as possibilidades de focos de Trypanosoma cruzi, uma vez que na região o número de casos de Doença de Chagas ainda é expressivo, conforme se constata através da fig.2.46.

\begin{tabular}{|c|c|c|c|c|c|c|c|c|c|c|}
\hline & AL & $B A$ & CE & MA & PB & PE & PI & RN & SE & Total \\
\hline \multicolumn{11}{|l|}{ Municipios } \\
\hline Pesquisados & NI & 111 & 96 & 14 & NI & 20 & NI & NI & 8 & 249 \\
\hline Positivos & - & 35 & & 4 & - & - & - & - & 7 & 46 \\
\hline$\%$ & - & 31,53 & 0 & 28,57 & - & - & - & - & 87,5 & 18,47 \\
\hline \multicolumn{11}{|l|}{ Localidades } \\
\hline Pesquisadas & - & 10.306 & 7.586 & 155 & - & - & - & - & 121 & 18.168 \\
\hline Positivas & - & 147 & 4.841 & 17 & - & - & - & - & 57 & 5.062 \\
\hline \% (dispersāo) & - & 1,43 & 63,82 & 10,99 & - & - & - & - & 47,11 & 27,86 \\
\hline \multicolumn{11}{|c|}{ Unidades domiciliares } \\
\hline Pesquisadas & 14.088 & 246.286 & 282.050 & 30.583 & - & - & - & - & 6.949 & 579.956 \\
\hline Positivas & 364 & 291 & 24.943 & 61 & - & - & - & - & 108 & 25.767 \\
\hline \% (infestaçăo) & 2,58 & 0,12 & 8,84 & 0,20 & - & - & - & - & 1,55 & 4,44 \\
\hline
\end{tabular}

$\mathrm{NI}=$ nảo informado

Fonte: Gerência lecnica de Doença de Chagas, Centro Nacional de Epidemiologia, Fundaçāo Nacional de Saúde.

Fig. 2.46. Esboço geral e perspectivas da doença de Chagas no Nordeste do Brasil (2000).

Porém, conforme já apontado, a opção de uma tecnologia de terra para as novas habitações indígenas reforça a manutenção e a reeleitura do emprego da terra com o objetivo da reconstituição de uma identidade construtiva perdida.

Como afirmado, após a realização das Oficinas de conscientização e envolvimento de 'reconhecimento' de uma tecnologia de terra adaptada, os Xucuru-Kariri de Caldas sentiram-se animados com as possibilidades das novas casas, para as quais 
acabaram apresentando sugestões sobre a incorporação de fibras à argamassa de terra, em especial, da palha de milho. Apontaram ainda para a possibilidade de agregar o esterco do gado à argamassa de terra, já que há na propriedade cerca de dezesseis cabeças de gado. Com pequenas modificações, a 'novaterra' se tornava de fato um sistema construtivo adaptado e contextualizado ao local, abrindo a possibilidade para sua reprodução e disseminação junto a outros proprietários de terra nas redondezas da Reserva Xucuru-Kariri. 


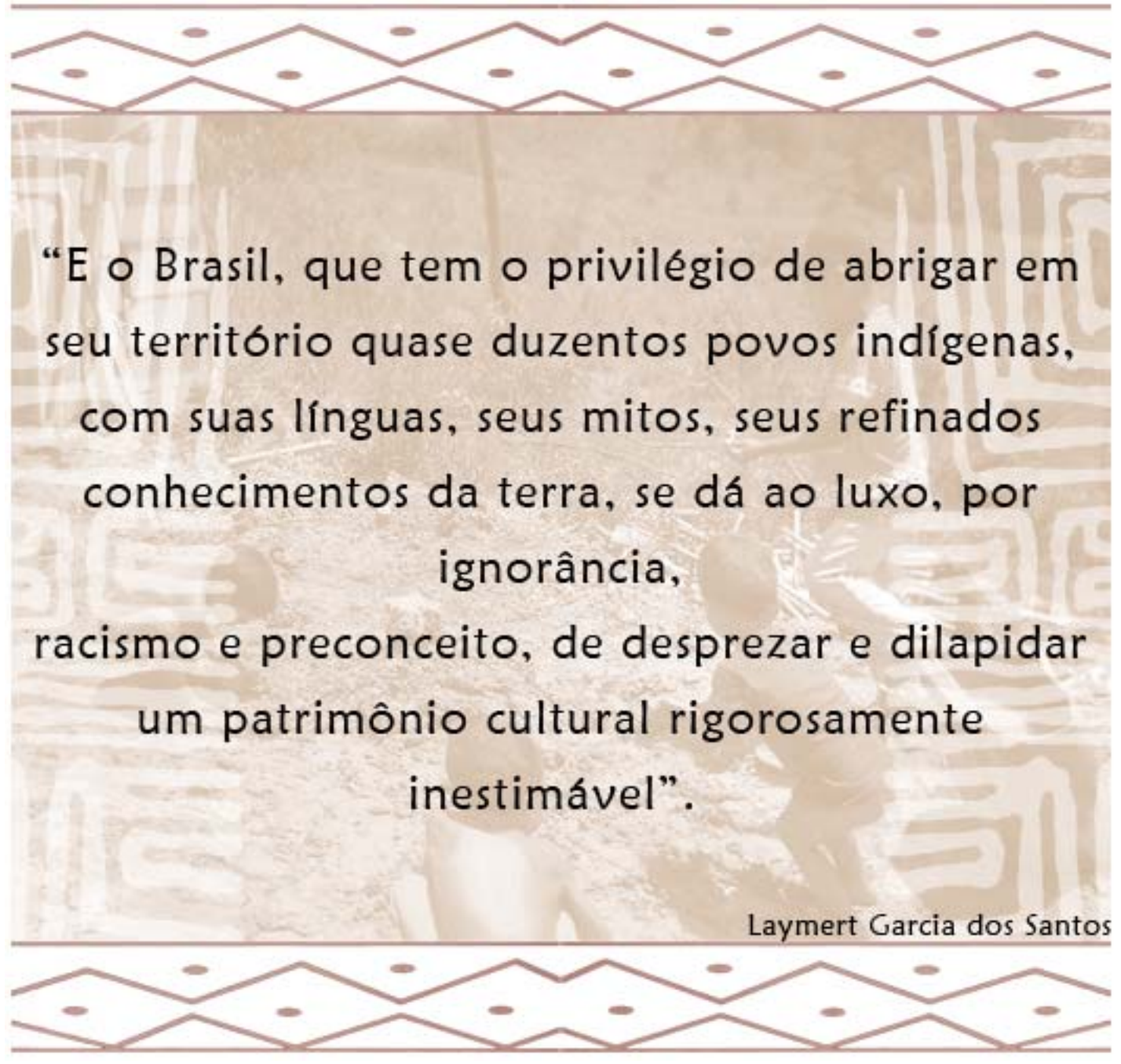

\section{Bases Metodológicas}

\subsection{A área de estudo: a Fazenda Boa Vista, atual Reserva Indígena}

A Reserva Indígena de Caldas é a denominação recente que recebeu a Fazenda Agropecuária Boa Vista, localizada a 9 km do centro urbano do município, dos quais 6 percorridos pela BR-459, que liga Caldas a Pouso Alegre, atualmente em bom estado de conservação, e $3 \mathrm{~km}$ percorridos por estrada de terra, cujo estado de 
conservação varia de acordo com a quantidade de chuvas e veículos que trafegam pela mesma.

Tal fazenda, com área de aproximadamente 100 hectares, cerca de 41 alqueires mineiros, pertencia ao Ministério da Agricultura. A área possui relevo com algumas sinuosidades, com pastagem e área de cultivo de 28 hectares - cerca de 11,5 alqueires, além de vegetação em mata nativa preservada. A fauna local é constituída de aves regionais como o tucano, juriti, canário da terra e outras de menor porte, além de cachorro-do-mato, gato-do-mato e variados animais de pequeno porte.

Pela facilidade de locomoção da Reserva até a cidade de Caldas, os índios XucuruKariri estão muito acostumados a adquirirem bens, gêneros alimentícios e demais produtos utilizados pelos moradores da cidade. É comum se ouvir dizer na Reserva indígena que este ou aquele índio foi para a 'rua'. Esta é a denominação adotada pelos índios para a área urbana de Caldas.

Nas imagens da fig.03.01. se observa a vista panorâmica da Reserva Xucuru-Kariri de Caldas e a placa afixada pelo Governo Federal, a qual faz referência ao grupo indígena em questão

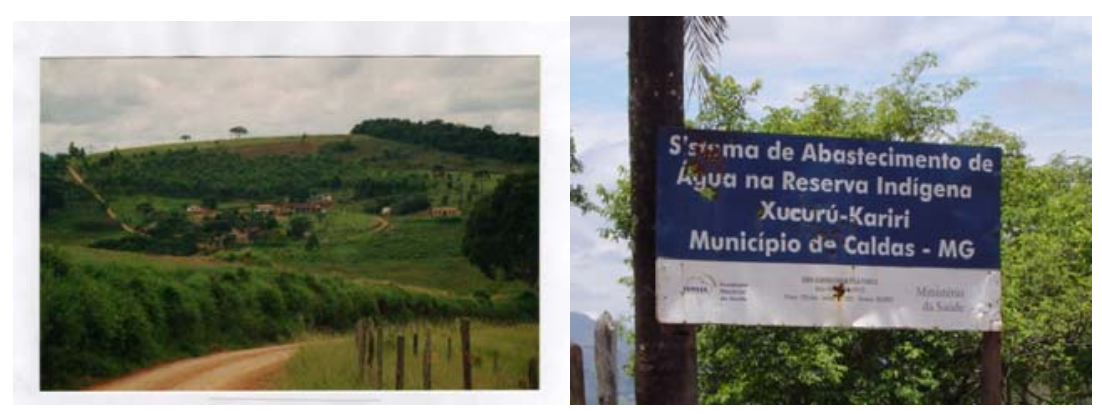

Fig.3.01. Observa-se nas imagens a vista panorâmica da Fazenda Boa Vista, atual Reserva Xucuru-Kariri de Caldas e a placa que faz referência junto a BR-459 ao Sistema de Abastecimento da referida reserva.

\subsection{Os solos encontrados junto a Reserva Xucuru-Kariri.}


Para que a experiência da construção com a 'novaterra' pudesse ser satisfatória, foi colhida uma amostra do solo junto da área determinada pelo Cacique José Sátiro para a construção das novas habitações.

Foram feitos testes expeditos para caracterização granulométrica do solo do local, através do teste do vidro (NEVES et al., 2005), o qual permitiu classificar o solo da Reserva Xucuru-Kariri como siltoso. Posteriormente, no Laboratório de Solos da PUC-Minas, campus de Poços de Caldas, o resultado foi confirmado, após ensaios de determinação da curva de distribuição granulométrica. Os ensaios acusaram uma composição de silte+ argila, perfazendo um total de 51,27\%, com $34 \%$ de argila,17,27 \% de silte, $10,72 \%$ de areia média e 38,01\% de areia fina, para o solo da Reserva Xucuru-Kariri, configurando um solo argilo-siltoso (com porcentagem ideal de argila e areia para produção da 'novaterra', apesar da quantidade de silte).

A partir desta informação, optou-se, efetivamente, por agregar fibras vegetais à argamassa de terra quando fosse iniciada a construção das habitações.

\subsection{As etapas de elaboração do projeto e construção.}

Como já mencionado, a 'novaterra' consiste em uma adaptação e melhoramento tecnológico da taipa de mão e, ao mesmo tempo, do bajareque, do bahareque e da quincha peruana para a região de Caldas, no sul de Minas Gerais. Tal adaptação e melhoramento decorreram da observação dos exemplares encontrados já construídos em taipa de mão pelos índios, assim como dos materiais, principalmente 
a palha de milho e bambu, abundantes no local, que poderiam proporcionar o melhoramento da tecnologia praticada pelos indígenas.

A primeira etapa do trabalho consistiu na elaboração de algumas alternativas de projeto que atendessem o programa das três unidades de habitação a serem construídas, a saber, a moradia menor, de um dormitório, a moradia intermediária, de dois dormitórios e a moradia maior, de três dormitórios. Os projetos foram elaborados com a participação de bolsistas e voluntários do Curso de Arquitetura e apresentados aos índios por meio de maquetes virtuais em 3D, apresentadas impressas e também por meio da utilização de um aparelho de televisão.

Os índios aprovaram os projetos e após a realização das oficinas em setembro e outubro de 2004, foi iniciada a obra, com a efetiva demarcação das três unidades sempre supervisionadas pelo Cacique José Sátiro, conforme se observa na fig.3.02.
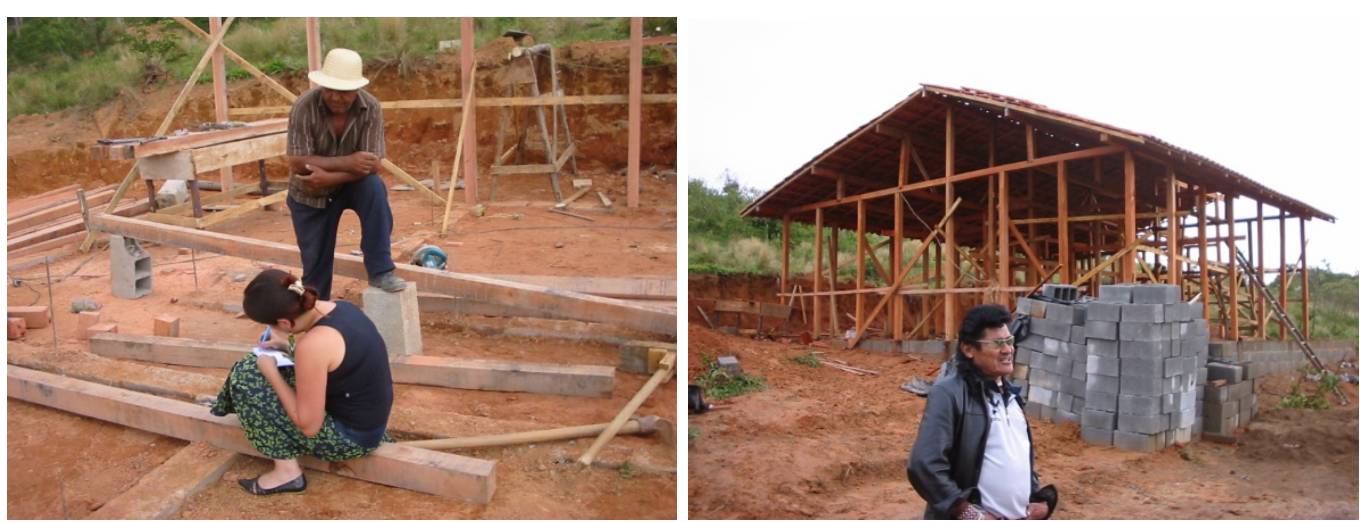

Fig. 3.02.O cacique José Sátiro e um dos índios envolvidos durante o processo de construção.

No capítulo anterior foi apresentado um painel de 'novaterra', tal como foi construído. Como a taipa de mão ou o bajareque, a 'novaterra' possui uma concepção e estrutura modular que foram base de sua produção. O módulo adotado desde a fase de projeto foi o emprego de painéis de 1,20 de largura, distância determinada de 
eixo a eixo de cada painel, distância que possibilita boa estabilidade construtiva para os painéis de madeira e bambu assim como para a parede como um todo.

Como processo construtivo, após a marcação da habitação junto ao terreno em área definida pelo Cacique Uarkanã, foram abertas valas para a construção de baldrame convencional, em que se empregaram canaletas de concreto, onde foi inserida a ferragem corrida. As brocas isoladas foram perfuradas com cerca de $1,50 \mathrm{~m}$ de profundidade, socadas e apiloadas. A cada 1,20m, ou seja, seguindo a modulação definida em projeto foram abertas as brocas. O concreto empregado foi preparado in loco respeitando-se o traço 3,5:1: 1. De cada uma das brocas saíram os ferros de arranque - barras de $1 / 4$ " de espessura que seriam introduzidas através de um furo de cerca de $20 \mathrm{~cm}$ de profundidade, no centro da base de cada esteio (coluna) vertical de madeira. A opção por uma estrutura de fundação convencional decorreu, primeiramente, da ausência de pedras no local para a realização de um outro tipo de fundação e da facilidade de execução que, em última análise, reforçou a proteção do embasamento da construção, tão necessário nas construções de terra devido aos possíveis problemas decorrentes da penetração de água nessas estruturas ${ }^{1}$.

Em seguida à execução do concreto das brocas e do baldrame, foram afixadas as colunas/esteios de madeira nas dimensões de 0,10 por 0,10, com cerca de 2,90 de altura, a cada 1,20 de distância. A partir das colunas, que tiveram cerca de 0,50 m de sua base protegidas com impermeabilizante do tipo Neutrol, foi montado todo o engradamento de madeira. O travamento dessa estrutura de base para a cobertura foi realizado simultaneamente, como se observa na fig.3.03.

\footnotetext{
${ }^{1}$ Conforme já apontado, de acordo com MEUNIER(1988), "uma boa casa de terra precisa ter um bom par de botas e um bom chapéu".
} 


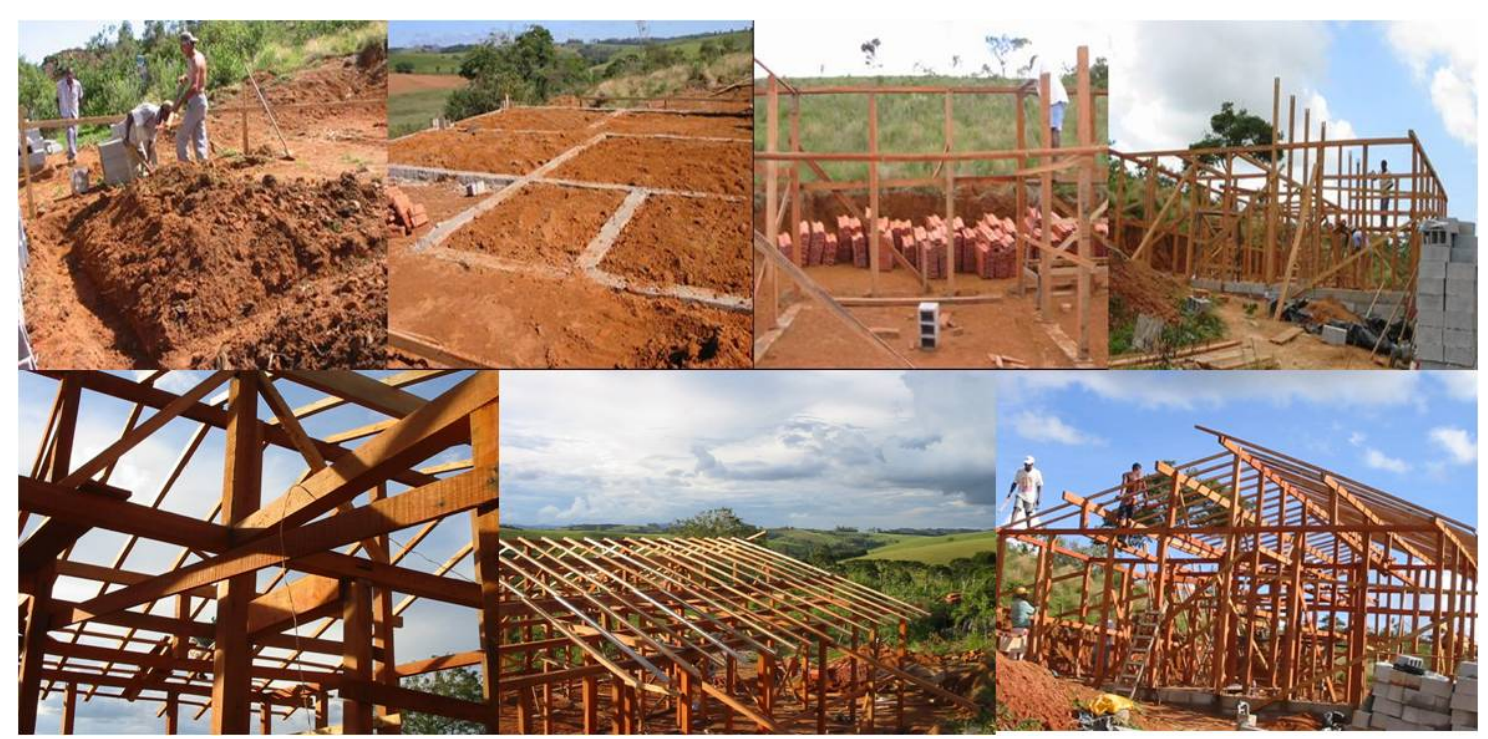

Fig.3.03. Detalhes da concepção da estrutura desde a base até a cobertura de uma das casas dos índios Xucuru.

A madeira utilizada foi o eucalipto (Eucalyptus grandis e Eucalyptus citriodora), adquirido numa Serraria da própria região, que possui, inclusive, uma área de reflorestamento junto da Fazenda Chiqueirão, no município de Poços de Caldas-MG, onde beneficia o eucalipto, distante cerca de $50 \mathrm{~km}$ da Reserva Indígena. Esta madeira foi tratada de forma caseira: foram aplicadas três demãos de óleo queimado sobre a mesma, que só foi empregada na execução após a total absorção do mineral $^{2}$.

A habitação foi coberta com telhas do tipo Romana, queimadas, procedentes de Olaria de Vargem Grande do Sul-SP, situada a cerca de 100 km de Caldas. Esta opção foi utilizada em função de a maior parte das casas da Reserva serem cobertas com telhas cerâmicas, como se observa na fig. 3.04.

\footnotetext{
${ }^{2} \mathrm{O}$ tratamento realizado se consistiu do banho frio de todas as peças de madeira em uma emulsão oleosa à base de creosoto por cerca de 4 horas, conforme recomendam especialistas em madeira.
} 


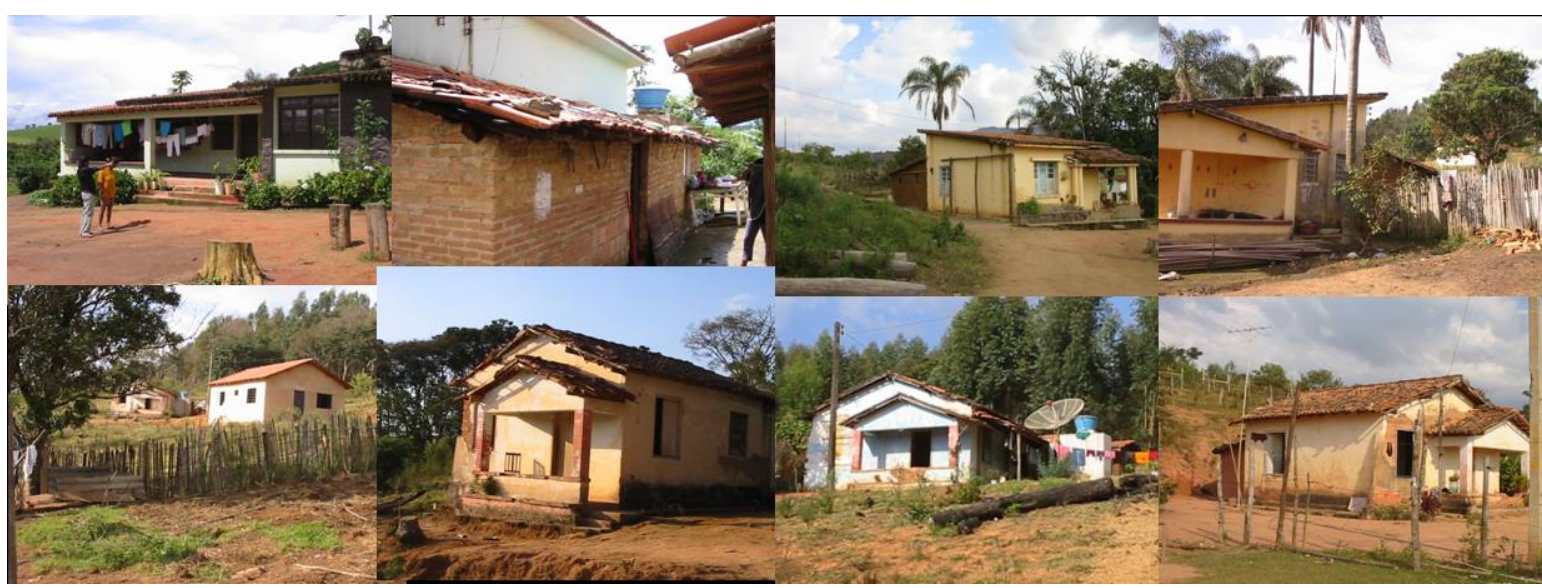

Fig.3.04. As unidades de habitação originais encontradas pelos Xucuru-Kariri na Fazenda Boa Vista, todas cobertas com telhas cerâmicas.

Após a cobertura, foi iniciado na habitação o assentamento de 6 fiadas de tijolos cozidos, procedentes de olaria localizada no município de Bandeira do Sul - MG, distante cerca de $41 \mathrm{~km}$ da Reserva, assentado entre os esteios de madeira, ocorrendo a proteção da última fiada com sacos de plástico reutilizados. Antes de se iniciar a estrutura de bambu, foram definidos os pontos de instalação de água e esgoto e todo o interior da edificação, depois de socado, recebeu contrapiso de concreto na proporção 3,5:3:1. Após a conclusão deste trabalho, foi iniciada a confecção da estrutura de bambu ${ }^{3}$ (entramado) até a altura de 2,90 e, em seguida, a confecção do entramado junto aos oitões da habitação ${ }^{4}$.

Simultaneamente ao trabalho do entramado, nos vãos onde havia aberturas (janelas e portas), foram afixados os respectivos batentes, também confeccionados com

\footnotetext{
${ }^{3}$ Como informado anteriormente, o bambu empregado foi extraído na própria Reserva Indígena. O corte, por recomendação dos próprios índios, ocorreu em período de lua minguante. Segundo costume indígena, se o bambu é cortado na lua minguante, as varas não são atacadas por brocas (Rhinastus latistermus). As varas de bambu foram também tratadas de forma caseira.

${ }^{4} \mathrm{O}$ pé direito das habitações em 'novaterra' foi definido em $2,90 \mathrm{~m}$ de altura. No entanto, todas as casas construídas pelos índios com a taipa de mão têm o pé direito muito mais baixo, com cerca de 2,20 a $2,25 \mathrm{~m}$ de altura. Quando os índios foram questionados sobre isso, responderam que esta medida decorre da maior facilidade de manusear as peças de madeira. Deve-se ressaltar que nenhuma das casas de taipa de mão existentes na aldeia possui forro.
} 
madeira do tipo eucalipto, adquiridos na Serraria mencionada, etapas que podem ser observadas na fig. 3.05.

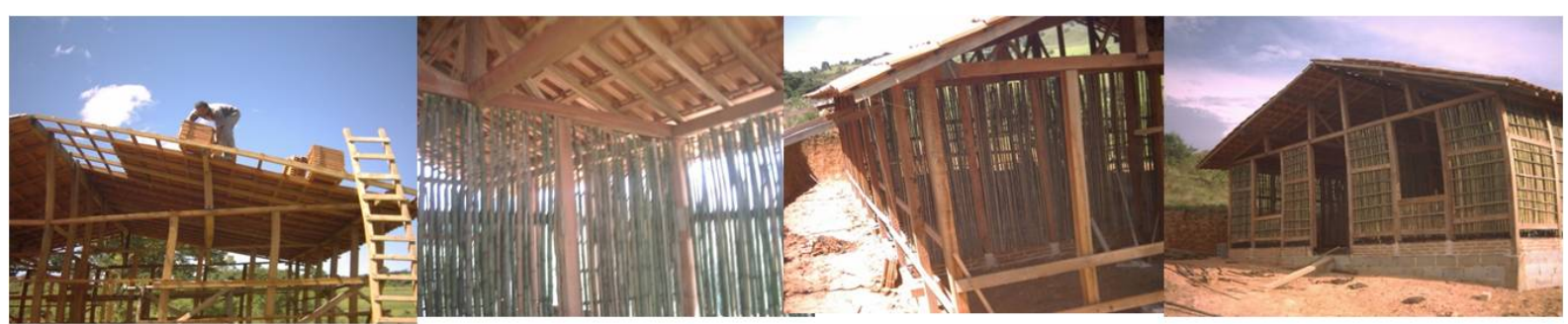

Fig.3.05. A cobertura, o entramado de bambu e a colocação dos batentes em uma das casas de 'novaterra'.

Nas paredes laterais dos esteios ou colunas de madeira de dimensões iguais a $0,10 \mathrm{~m} \times 0,10 \mathrm{~m}$ foram colocados, em maior quantidade, pregos $15 \times 15$ para promover a articulação do barreamento com a estrutura de madeira, local que funciona como junta de dilatação, como será possível observar na fig.3.06.

\section{Sistema Misto NOVATERRA}

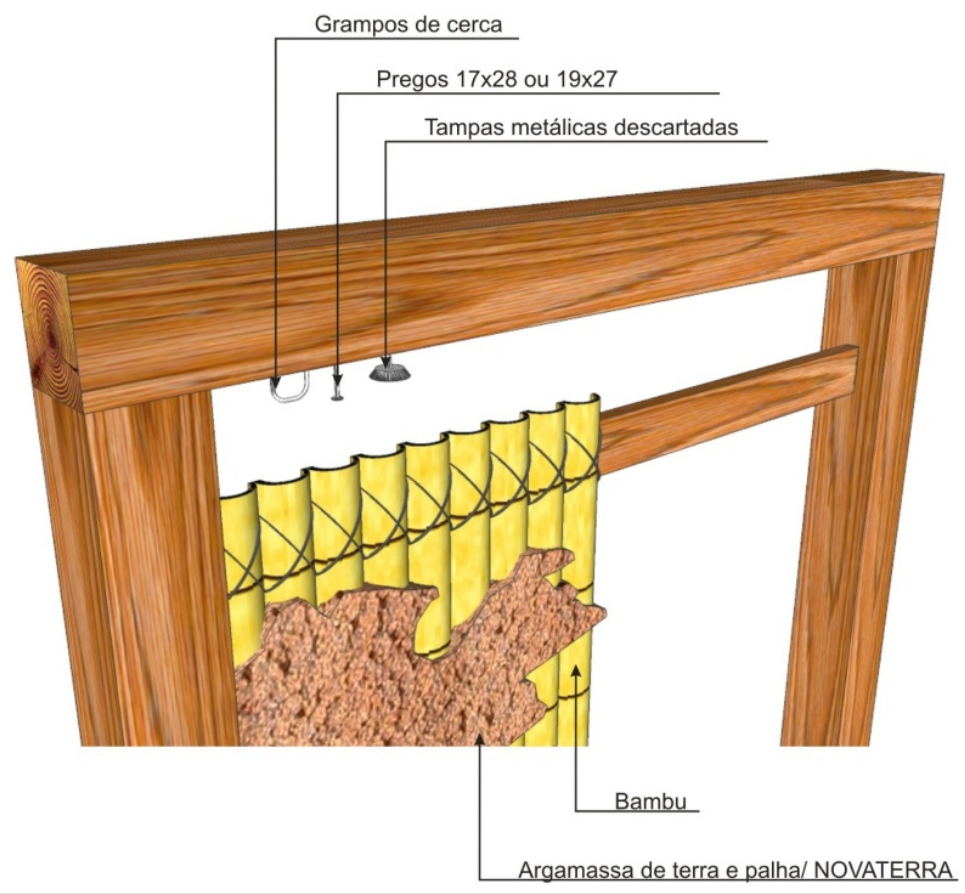

Fig. 3.06. Elementos afixados nas peças de madeira para promover a ligação entre a madeira e a argamassa da 'novaterra' 
Após a conclusão desta etapa é que se iniciou o barreamento ou preenchimento, atividade que mobilizou toda a comunidade indígena ${ }^{5}$. A palha de milho triturada em desencaroçadeira elétrica, em sítio vizinho da Reserva Indígena, foi paulatinamente adicionada à mistura da terra previamente peneirada, na qual foi adicionada água e areia, na proporção de sete partes de terra para uma de areia e uma de palha, etapa que pode ser observada através da fig. 3.07.

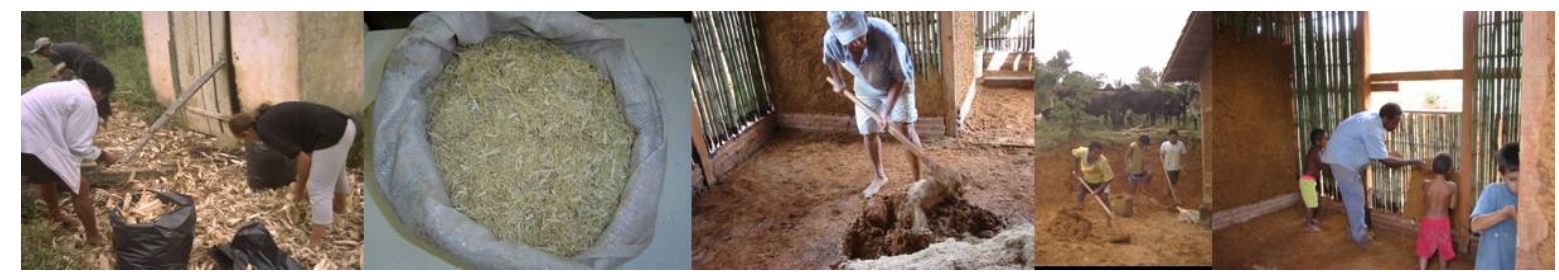

Fig.3.07: Separação da palha, trituração, preparação da massa para o barreamento e barreamento na Reserva Xucuru-Kariri.

A maior dificuldade de execução durante a etapa do barreamento ocorreu no período em que houve o preenchimento da estrutura dos oitões, devido à altura da edificação.

Uma semana depois de concluído o barreamento, foi realizado o preenchimento de fissuras que acabaram ocorrendo em decorrência da retração da argamassa de terra, preenchimento realizado em duas etapas distintas. Em seguida, foi cuidadosamente presa a toda a estrutura, a tela de galinheiro proveniente de reutilização, afixada com pregos $15 \times 15$, em todas as paredes, tanto internas quanto externas, conforme se observa na fig.3.08.

\footnotetext{
${ }^{5}$ Nas etapas iniciais da obra os índios se envolveram muito pouco, havendo momentos em que foi necessária a contratação de mão-de-obra externa à Reserva Indígena. O barreamento ocorre como um ritual, uma verdadeira festa em que os índios, homens, mulheres e crianças participam e evocam cânticos da etnia.
} 


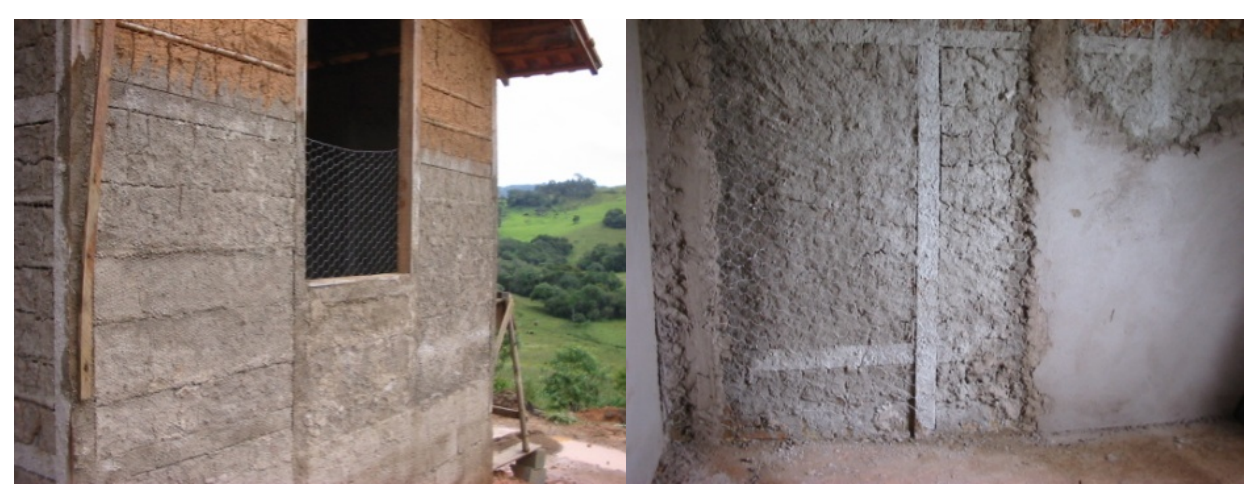

Fig. 3.08. A tela, o chapisco e o início da argamassa de revestimento de casa Xucuru-Kariri.

Sobre a tela houve a aplicação de chapisco convencional com o emprego de terra local peneirada, areia lavada e cimento, na proporção 4:2:1, sobre o tela. Após este trabalho, foi feito o trabalho de reboco da edificação com o emprego de terra, cal, areia fina e cimento na proporção 10:1,5 :1 .

Deve-se salientar o fato de que o acabamento utilizado para as habitações construídas em 'novaterra', empregou reboco desempenado por solicitação dos próprios índios, muito aculturados e resistentes à utilização de uma argamassa de revestimento mais rústica, mais próxima daquelas anteriormente empregadas nas construções rurais da Serra da Mantiqueira, como relatara Ferraz, em 1992, no belo exemplar do "Arquitetura Rural da Serra da Mantiqueira", originado após seu envolvimento durante a pesquisa e participação da montagem da exposição "Caipiras, Capiaus: Pau-a-Pique”, dirigida por Lina Bo Bardi e apresentada no Centro de Lazer SESC Fábrica Pompéia, a partir de 26 de junho de 1984, conforme pode se observar na fig.3.09. 


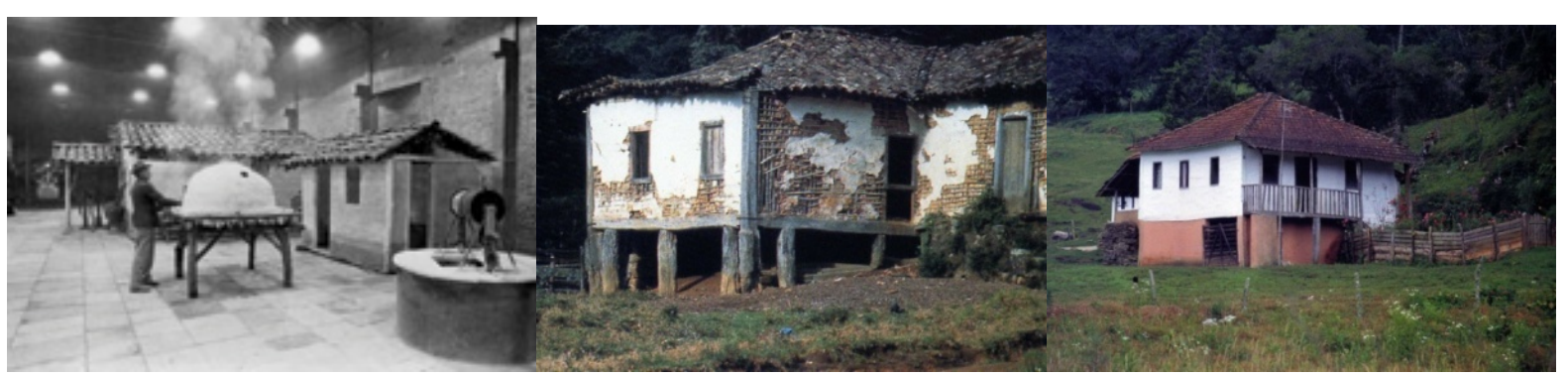

Fig.3.09. A Exposição Caipiras,Capiaus:Pau-a-pique e algumas casas rurais mineiras da obra de Marcelo Ferraz.

Com a finalização do reboco, foram também concluídos os trabalhos de instalações hidráulicas e elétricas, ambas afixadas de forma aparente a fim de não se danificarem os painéis de terra, além de facilitar os trabalhos de manutenção da construção necessários posteriormente, etapa que poderá ser observada na fig.3.10.

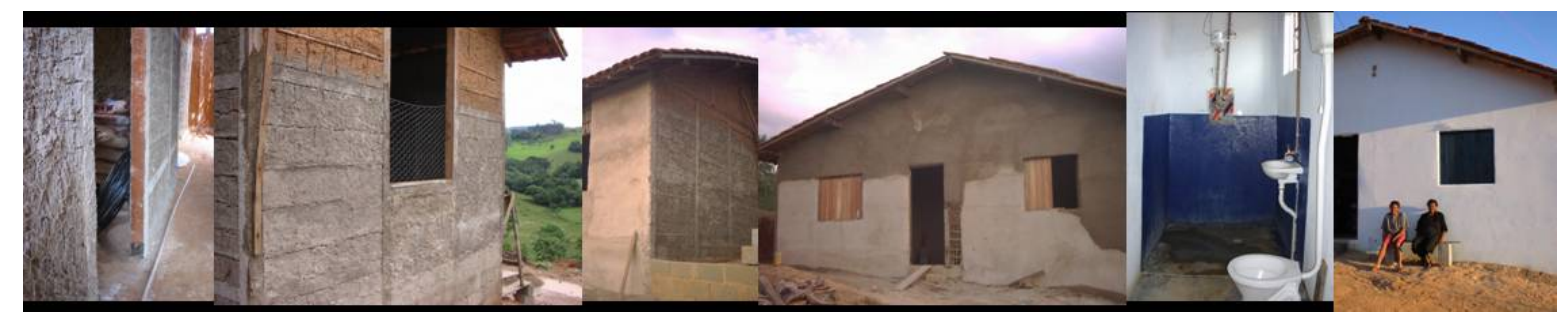

Fig.3.10. O chapisco, reboco, instalações hidráulicas e acabamento de uma das casas em 'novaterra'.

Em seguida, foi concluído o serviço de acabamento do piso com cimento queimado, sarrafeado e desempenado, também uma opção solicitada pelos próprios índios. Foram afixadas aos batentes as aberturas externas da habitação. Como afirmado anteriormente, tais elementos foram confeccionados em eucalipto na mesma serraria que forneceu a madeira para as estruturas. 
A caiação e pintura das aberturas foram realizadas pelos próprios índios, em particular, pelos futuros moradores da habitação. Foi também escolhida por eles a cor de acabamento das madeiras. À cal das paredes foi adicionado pigmento azul na proporção de dez partes de cal para uma parte de pigmento e as portas e janelas de madeira, já protegidas com selador de madeira, receberam pintura à base de óleo na cor azul royal.

Quanto à confecção dos forros para as casas, como comentado anteriormente, não foi possível forrar totalmente as unidades. Assim decidiu-se por um cômodo da casa de três dormitórios, o dormitório com parede voltada para a face norte. Esta habitação foi ocupada por uma das famílias da Reserva Indígena com um maior número de membros. Além disso, no decorrer da pesquisa, a casa de três dormitórios foi aquela que acabou sendo concluída em primeiro lugar e, posteriormente, utilizada durante a etapa de avaliação do conforto térmico, como poderá se observar no tópico relativo às avaliações térmicas.

Além de se optar pela confecção do forro em apenas um cômodo, definiu-se adotar o mesmo procedimento para a casa construída com materiais convencionais com recursos disponibilizados, como comentado anteriormente, pela comunidade católica de São Pedro de Caldas. Ou seja, nesta habitação convencional, denominada na pesquisa como 'habitação testemunho', o forro foi também executado em apenas um cômodo, um dormitório, voltado para a face norte. Como se discorreu, as avaliações térmicas e seus comentários ocorrerão em tópico subseqüente. 
Deve-se, no entanto, salientar que, em decorrência de problemas de recursos financeiros, os forros dos dormitórios das duas unidades ora especificadas, a habitação com três dormitórios construída em 'novaterra' e a habitação convencional 'testemunho', foram concluídos no final de novembro de 2007. Voltando a mencionar as unidades de 'novaterra', a moradia de dois dormitórios ficou pronta cerca de dez meses depois daquela com três dormitórios. Na verdade, as fases de alicerces, estrutura e cobertura das três unidades de habitação em 'novaterra' foram executadas ao mesmo tempo. Em seguida, a fase de confecção do entramado, colocação dos batentes e preenchimento com argamassa de terra e palha foi executado apenas nas moradias de três e dois dormitórios.

Houve uma resistência muito grande do Cacique Uarkanã em relação à unidade de um só dormitório, principalmente no que diz respeito ao número de cômodos da mesma. Assim, esta moradia de um dormitório, por muito tempo, ficou paralisada. A outra unidade de dois dormitórios onde foi empregada a 'novaterra' foi ocupada de forma precária, desde quando concluído o reboco e confecção do piso cimentado, ficando as fases finais de pintura para uma etapa posterior, que foi parcialmente concluída no final de 2007.

Em decorrência de que uma das grandes queixas dos Xucuru-Kariri dizia respeito ao frio em Caldas, como apontado anteriormente, a opção para a escolha do forro levou em consideração o respeito à identidade construtiva rural e indígena - já que esta reproduziu algo muito semelhante àquilo que fora encontrado em outras habitações 
de propriedades da região: o emprego de uma esteira de bambu trançado no forro ${ }^{6}$, aspecto que pode ser observado nas imagens da fig.3.11.
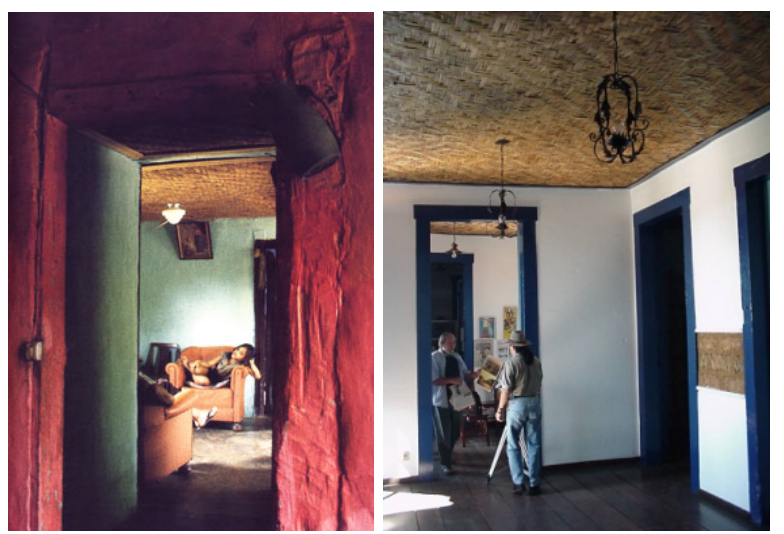

Fig.3.11. Uma casa 'caipira' em São Sebastião do Bonsucesso.MG, em que pode se verificar o forro de bambu.

A fim de melhorar o conforto térmico da habitação principalmente no inverno, entre o forro confeccionado com a esteira em bambu e o engradamento do telhado, foi afixada uma subcobertura executada com caixas de leite do tipo tetrapak, conforme mencionado anteriormente.

A respeito dos efeitos produzidos antes e depois da colocação dos forros e da subcobertura nas habitações, a questão será amplamente trabalhada em tópico subseqüente.

Após a conclusão da habitação de três dormitórios em 'novaterra', para que fosse possível o início das avaliações térmicas, foi definida em planta a localização dos sensores, tanto nesta moradia em 'novaterra', quanto na moradia 'testemunho',

\footnotetext{
${ }^{6}$ A idéia inicial seria utilizar taquaras para a elaboração do forro. Porém, havia no período pequena quantidade de taquara na Reserva e nos arredores. Como os índios não quiseram participar do processo de confecção da esteira de bambu, alegando terem outras 'atividades' para serem desenvolvidas na Reserva, foi contratado um "balaieiro", morador do povoado do Rio Pardo, no próprio município de Caldas, para realizar a tarefa de confecção do forro em bambu.
} 
aspecto que será discutido no tópico 08 deste capítulo que trata das avaliações térmicas.

\subsection{Os arranjos construtivos propostos e os arranjos finais da construção.}

A proposta inicial para as três unidades de habitação em 'novaterra', como afirmado anteriormente, seguiu uma concepção modular onde foi adotado um módulo básico de $1,20 m \times 1,20 m$ para que fosse garantida a estabilidade estrutural da edificação.

Como já comentado, a concepção de cada uma das unidades foi apresentada aos índios através da simulação de maquetes eletrônicas.

No entanto, durante o processo de execução, os Xucuru-Kariri acabaram solicitando alterações do arranjo dos cômodos propostos e a incorporação do banheiro ao interior da edificação, uma vez que a porta de acesso a este compartimento abria do lado de fora da edificação, em local onde estava prevista a ampliação posterior com a construção de uma varanda. Tal mudança ocorreu com a criação de um pequeno trecho de corredor para o acesso ao banheiro.

Outra alteração diz respeito à localização do fogão de lenha que, na proposta inicial, deveria ser construído no interior da cozinha, como forma de, em períodos frios, possibilitar o aquecimento da edificação. Porém, o referido fogão acabou sendo implantado em varanda edificada pelos índios junto da moradia após a conclusão da obra. Na habitação de dois dormitórios, o processo de rearranjos internos foi semelhante ao descrito para a unidade de três dormitórios. Outras alterações se 
referem à localização dos acessos das duas moradias (de dois e de três dormitórios). A forma de acesso às habitações foi alterada pelos índios como se as casas tivessem sido 'espelhadas', ou seja, tivessem sido construídas de maneira inversa. A última alteração, bastante curiosa, diz respeito à reivindicação para que as portas externas fossem serradas ao meio, possibilitando o acesso e saída das crianças pequenas e de animais domésticos através do segmento inferior.

$\mathrm{Na}$ verdade, ainda que a adaptação tecnológica se consistisse como novidade para os índios, os costumes das famílias foram incorporados ao desenho proposto para essas moradias. Com a experiência construtiva pode-se constatar que os índios somente conseguiram "visualizar" como suas moradias ficariam acabadas, quando os alicerces já estavam implantados.

Verificou-se que teria sido necessária a elaboração de modelos/maquetes simplificadas, em escala 1:1, em etapa anterior ao início das casas de 'novaterra', para que os índios tivessem a real compreensão dos espaços das moradias. Tal alternativa foi experimentada de forma satisfatória por CASTAÑEDA (2003-2004), quando construiu um protótipo com o envolvimento de famílias que dispunham de poucos recursos para executar suas habitações em local denominado Reserva de La Biosfera "La Sepultura", envolvendo três comunidades: Corazón Del Valle, Raymundo Flores e Sierra Morena, todas localizadas em Chiapas, ao sul do México.

Primeiramente elaboraram uma maquete em escala 1:25 e depois realizaram a experimentação em campo, com a participação da comunidade. Esta experiência pode esclarecer todas as dúvidas dos futuros moradores, além de possibilitar 
pequenos reajustes pelos mesmos solicitados, conforme poderá se observar na fig.3.12.

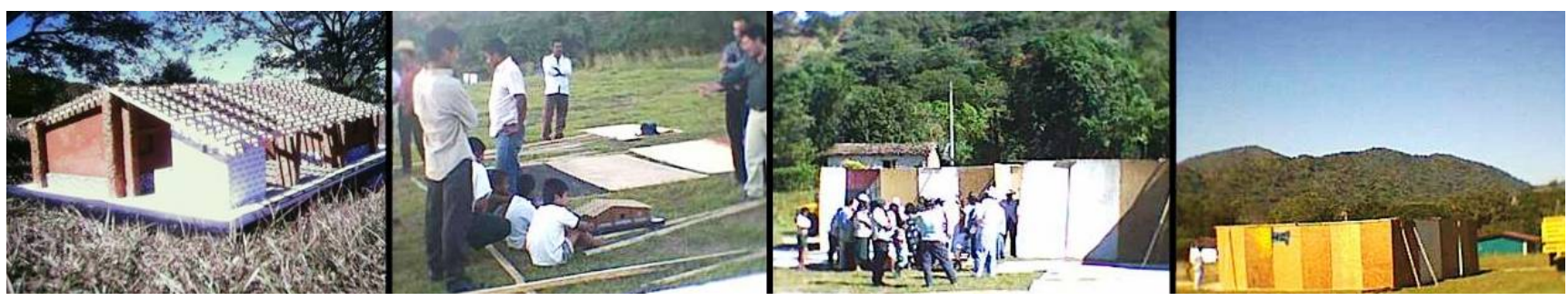

Fig.3.12..A experiência com as comunidades sul-mexicanas.

Diferentemente do que ocorreu durante a implantação das habitações em 'novaterra', o entendimento da concepção da moradia por parte da comunidade mexicana foi plenamente satisfatório. No entanto, os problemas ocorridos no México disseram respeito às dificuldades financeiras. Não foi possível a implantação desta rica experiência. Apenas uma outra executada com tecnologia alternativa diversa foi implantada em Poza Galana, também em Chiapas.

\subsection{Construindo uma nova experiência no canteiro de obra.}

A primeira questão a se comentar quanto ao desenvolvimento da obra diz respeito à dificuldade, já apontada, do envolvimento dos índios durante o processo construtivo. Quando da realização das duas oficinas de conscientização sobre a tecnologia de terra adaptada e melhorada, como comentado anteriormente, os índios pareceram bastante satisfeitos com o processo construtivo e até as mulheres e crianças se envolveram nas atividades propostas. No entanto, a partir do momento em que as obras foram de fato iniciadas, houve grande resistência do grupo no que se refere ao trabalho.

Primeiramente, o cacique solicitou que a verba destinada pela Mitra Diocesana e Cáritas Brasileira para a construção lhe fosse entregue, a fim de que ele mesmo 
pudesse 'gerenciar' os recursos. Não entendia que os recursos deveriam ser aplicados paulatinamente, conforme o desenvolvimento da obra, conforme um cronograma de desembolso. Outro fato ocorrido durante o processo construtivo foi a dificuldade de realmente envolver os índios no processo de trabalho. Insistentemente diziam que para trabalhar deveriam ser remunerados, não entendendo que, se o dinheiro fosse empregado para sua remuneração, as obras não poderiam ser concluídas, uma vez que o processo de auto-construção fora escolhido, essencialmente, porque somente assim seria possível viabilizar a construção as três unidades de habitação.

Quanto à instalação de benfeitorias necessárias para o funcionamento das unidades de habitação, como a rede de energia elétrica e confecção de fossas para o lançamento dos esgotos domésticos, ficariam sob a responsabilidade da comunidade. Com a fase de conclusão da primeira habitação em 'novaterra', tanto a rede de alimentação elétrica quanto a execução das fossas acabaram sendo realizadas com recursos oriundos de suplementação dos valores destinados à obra. Tais recursos foram disponibilizados pela Mitra Diocesana de Guaxupé e a Pontifícia Universidade Católica de Minas Gerais, uma vez que as habitações não poderiam entrar em funcionamento sem a instalação dessas benfeitorias.

Outro aspecto que a pesquisa aponta, como comentado anteriormente, diz respeito ao pé-direito definido para as três habitações em 'novaterra' e o pé direito empregado pelos índios nas unidades executadas em taipa de mão. Além do aspecto da facilidade construtiva relatado pelos índios, a altura definida como pé direito dessas unidades executadas pelos índios se relacionam muito mais com o 
padrão de altura das pessoas do grupo do que com a legislação e normas brasileiras pré- estabelecidas, aspecto que pode ser observado na fig.3.13.

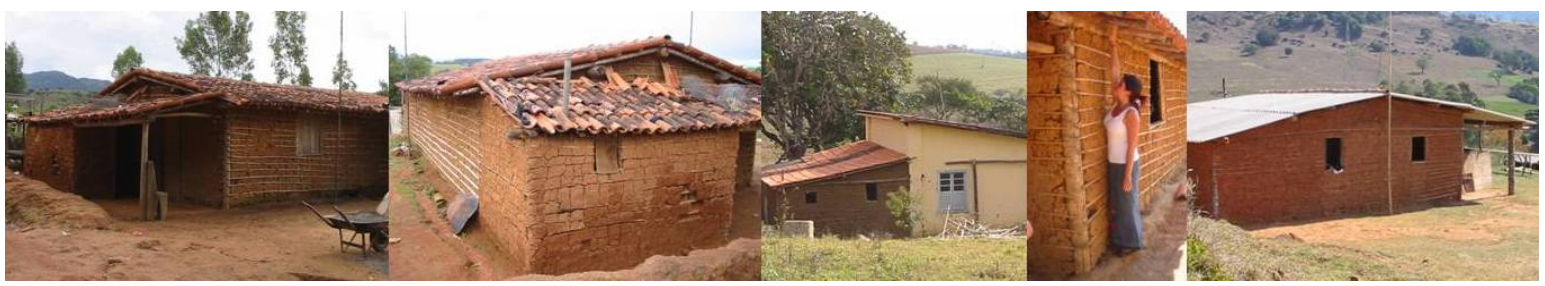

Fig.3.13. A altura das construções e ampliações executadas pelos Xucuru-Kariri na Reserva de Caldas.

Relativo à experiência no canteiro de obra, há ainda outro ponto importante que deve ser observado: as aberturas externas para as unidades de habitações indígenas quase nada significam quando a análise diz respeito ao conforto da habitação. Provavelmente, em decorrência da grande dificuldade de adaptação dos índios ao frio do sul de Minas, não só nas unidades de 'novaterra' ou na habitação 'testemunho', as aberturas de todas as moradias da Reserva de Caldas permanecem quase sempre fechadas ou lacradas, principalmente durante períodos mais frios, como se pode observar a seguir na fig. 3.14.

Esta postura impede a circulação de ar e, conseqüentemente, dificulta o equilíbrio térmico entre os ambientes exterior e interior.

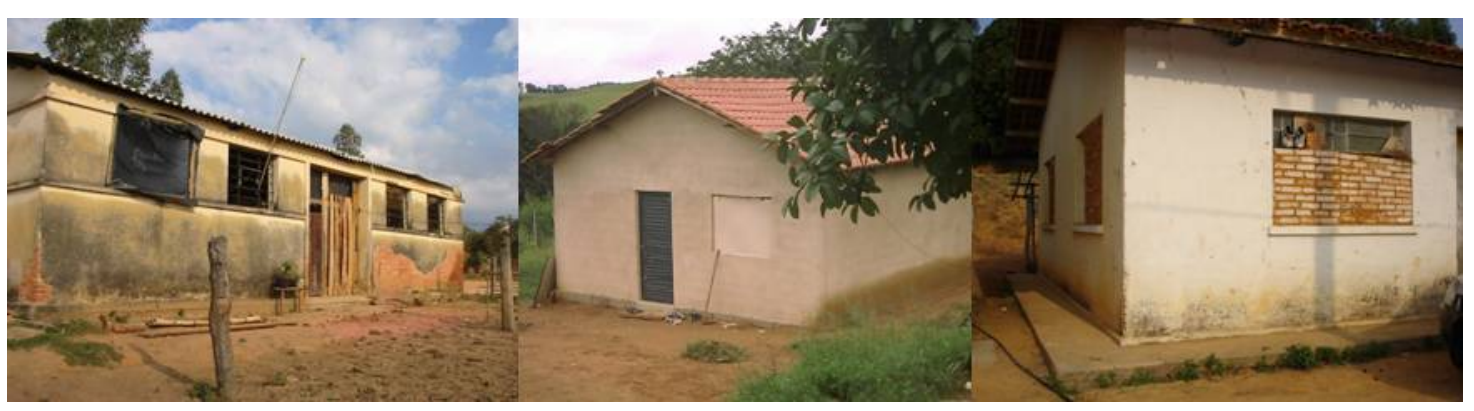

Fig.3.14. Aberturas fechadas e lacradas que demonstram a dificuldade de adaptação dos índios em relação ao frio do sul de Minas Gerais.

Por último, a unidade de habitação de um dormitório não foi concluída por determinação do cacique. Após a conclusão das outras duas unidades de habitação 
em 'novaterra', o grupo indígena acabou terminando a unidade de um dormitório da forma que tradicionalmente construíam em terra, ou seja, utilizando o sistema da taipa de mão ou pau-a-pique. Fica claro que, ainda que os membros do grupo indígena achassem muito interessante o melhoramento e adaptação da tecnologia que eles mesmos denominaram como 'novaterra', a resistência dos índios se mantinha. Um dos fatores, possivelmente poderia ser o motivo de o grupo indígena não ter sido o responsável pelo gerenciamento do processo construtivo das habitações.

No início do processo havia grande expectativa e incentivo para que, a partir do aprendizado e aprimoramento do sistema construtivo da 'novaterra', os índios passassem a oferecer e realizar obras com esta tecnologia junto das propriedades da região: pequenos sítios e chácaras onde muitas vezes pequenas obras de novas construções e/ou ampliações se fazem necessárias. Infelizmente, tal expectativa se demonstrou frustrada uma vez que, como já apontado, além de se envolverem parcialmente na construção de suas próprias habitações, os índios continuamente exigiam outras benfeitorias como a manutenção das casas existentes na Reserva, a substituição de lâmpadas, pisos, entre outros. Estas solicitações não puderam ser realizadas em decorrência de que não foram esses os propósitos a serem atingidos tanto pela pesquisa quanto pela PUC-Minas e Cáritas Brasileira /Mitra Diocesana de Guaxupé, que liberaram os recursos utilizados durante as obras. 


\subsection{A racionalização do detalhamento do projeto da estrutura de madeira com objetivo de realizar um processo construtivo racional e sustentável.}

Durante o processo construtivo, devido às dificuldades de se saber como ocorreria a liberação de recursos para a construção, as três unidades propostas tiveram suas estruturas de madeira e engradamento de telhado executados em sistema convencional, por um oficial de obra especializado. Não ocorreu um detalhamento de projeto da estrutura de madeira, o que poderia, em alguma medida, gerar a redução de custos e racionalização de cortes, além do melhor dimensionamento de peças, essenciais para a racionalização das perdas de madeira e diminuição do consumo de madeira empregado na estrutura das casas em 'novaterra'.

Conforme será possível observar nos anexos, a partir dos projetos arquitetônicos dos três modelos de habitação, foi elaborado um projeto detalhado para as estruturas de madeira, pretendendo-se ampliar as possibilidades de reprodução do sistema construtivo não só na Reserva Indígena, como também em quaisquer outros locais, tanto urbanos quanto rurais, como alternativa para a constituição de exemplares de construção sustentáveis, passíveis de serem reproduzidos em grupos de habitações, em mutirões ou em quaisquer lugares onde haja o desejo e necessidade de novas moradias.

A questão da racionalização e reprodutibilidade da tecnologia adaptada e melhorada será abordada nos resultados e discussão da presente pesquisa. 


\subsection{Avaliações Térmicas: significados e importância}

De acordo com SIQUEIRA et al. (2005), “o desempenho térmico de edificações é um fator importante em habitações, notadamente naquelas destinadas a pessoas de baixa renda. Uma edificação projetada para o clima no qual está inserida torna-se confortável, além de economizar energia. A avaliação do desempenho térmico de uma edificação engloba a resposta global do projeto arquitetônico proposto em relação às trocas térmicas entre o ambiente construído e o ambiente externo, onde a caracterização das condições climáticas locais é uma das etapas mais importantes.

As condições de exposição da edificação ao clima são caracterizadas pelos valores locais horários da radiação solar, da temperatura e umidade relativa do ar e também pela velocidade predominante do vento". Já VECCHIA(1997) aponta para a questão de que "as variações da temperatura e umidade do ar, a direção e velocidade dos ventos predominantes, a intensidade da radiação solar, etc. permitem estabelecer variáveis com as quais as sensações de bem-estar são analisadas e avaliadas, dependendo do tipo de método utilizado para isso". Esses diferentes mecanismos de avaliação, segundo o autor, determinam os "índices de conforto" que se estruturam através de parâmetros que os compõem e qualificam o ambiente no processo de investigação de sua "qualidade térmica". Os dois autores apontam para o importante aspecto da realização das avaliações térmicas.

A relevância dessas análises dizem respeito não só ao aspecto tecnológico e experimental, mais que isso, os resultados acabam por possibilitar correções nos procedimentos construtivos de cada uma das tecnologias construtivas adotadas, 
adequando-as à realidade de cada lugar, além de possibilitar, através dos resultados, a tomada de decisões de mudanças ou aprimoramentos projetuais e construtivos visando melhor adequação da edificação às condições climáticas e geográficas de cada local.

\subsection{Avaliação Térmica de uma das habitações em 'novaterra' e da habitação 'testemunho': análise e interpretação dos resultados junto à Reserva Xucuru- Kariri}

Esta pesquisa, ao reinterpretar a cultura construtiva dos índios Xucuru-Kariri que empregam a terra há algumas gerações, escolheu este material pautando-se, como comentado anteriormente, entre outros fatores, em sua abundância na Fazenda Boa Vista, atual Reserva Indígena. Porém, pretendia-se desde o início averiguar as propriedades da terra como material de construção e suas potencialidades como material que regula a umidade ambiental e que armazena calor, conforme apontam Milanez (1958) e Minke (2005), entre outros.

Para tanto, depois da construção da habitação de três dormitórios em 'novaterra', decidiu-se realizar avaliações sobre o desempenho térmico dessa moradia e, ao mesmo tempo, averiguar o conforto ambiental de uma moradia construída de forma convencional, denominada 'habitação testemunho', como já apontado anteriormente. Como um dos objetivos desta pesquisa, além de reconstituir a trajetória do grupo Xucuru-Kariri é essencialmente a habitação e, em particular, a habitação de interesse social, uma das maneiras de entendê-la dentro da Arquitetura parte das 
expressões construtivas de forte caráter regional e que podem guardar uma estreita relação com o lugar.

Porém, o panorama mais comum que hoje pode ser observado na construção de habitações descarta o uso de materiais naturais, ou alternativos, dos elementos construtivos originais e das tradições locais próprias, desprezando-se a experiência acumulada durante séculos.

Por esta razão, este trabalho busca a retomada do uso de um material local na edificação de construções com vista, além de outros fatores anteriormente apontados, à adequação climática.

Para tanto, foram realizados recortes de três episódios representativos do fato climático, baseados na abordagem dinâmica do clima, o que permitiu a análise satisfatória em curto período de tempo cronológico, durante as três situações diversas apresentadas a seguir. As avaliações de desempenho térmico partiram da análise correlativa das condições internas de temperatura (do ar e superficial) da habitação em 'novaterra' e de uma habitação de bloco de concreto, tomada como 'testemunho' de uma tecnologia construtiva convencional.

Relativo ao comportamento térmico das duas edificações escolhidas, a pesquisa se baseou em processos experimentais com o monitoramento automático dos dados acerca do clima, assim como dos parâmetros ambientais de avaliação térmica dos ambientes internos das moradias (comportamento térmico), utilizando equipamentos da marca HOBO-8 para registros de calor e umidade no interior e no exterior das edificações. 
Os três períodos definidos para as análises na Reserva de Caldas foram, respectivamente, o período compreendido entre os dias 27 de outubro e 01 de novembro de 2005 e entre os dias 11 e 31 de maio de 2006. Nessas duas primeiras situações, as habitações analisadas, respectivamente, a construída em 'novaterra'(A) e a construída com blocos de concreto, a habitação 'testemunho' (B) ainda não tinham cômodos forrados. Em cada um desses períodos foram-se tomando leituras automáticas a cada 20 segundos e contabilizando a média a cada 30 minutos, o que corresponde a 180 leituras de cada sensor por hora ${ }^{7}$.

Como já apontado anteriormente, a habitação de 'novaterra' (A) foi construída entre 2004 e 2005 com recursos fornecidos por uma parceria entre a Cáritas Brasileira e a PUC - Minas, campus de Poços de Caldas e corresponde a uma habitação com $93,55 \mathrm{~m}^{2}$, incluindo-se uma varanda de $12,85 \mathrm{~m}^{2}$.

Extensivamente relatadada, a habitação em 'novaterra' procurou resgatar o conhecimento da tecnologia em terra, especificamente o bajareque mejorado e a taipa de mão, pelos índios, melhorando e adaptando tal sistema construtivo às especificidades do lugar.

Já a moradia denominada como 'testemunho' (B) foi construída em sistema convencional, empregando blocos de concreto em sua alvenaria, com revestimento em reboco também convencional e piso executado com cimento queimado, sarrafeado e desempenado. As esquadrias de ferro externas são industrializadas e a

7 Reforçando o que já foi apontado anteriormente, estas leituras significam o dobro daquilo que propõe a norma da Organização Mundial de Meteorologia-OMM, ainda que a preocupação no presente trabalho tenha sido a de responder as perguntas da pesquisa proposta com o máximo de precisão dos dados registrados de maneira automática. 
cobertura empregou engradamento de madeira e telhas cerâmicas do tipo romanas, sem laje e sem forro .Tanto a habitação em 'novaterra' (A) como a habitação 'testemunho'(B), pode ser observadas na fig.3.15. Esta habitação (B), que como já informado, foi construída em 2004 com recursos fornecidos por um grupo católico holandês, possui uma área construída de 55,55 $\mathrm{m}^{2}$, é composta de dois dormitórios, copa/cozinha, sala de estar e banheiro, executada aos moldes de habitações urbanas de interesse social. Uma curiosidade diz respeito aos fechamentos para as esquadrias desta moradia, como também já comentado anteriormente: os índios, literalmente, lacraram as aberturas com pedaços de madeirit ou folhas de eucatex, a fim de se protegerem contra o frio e as intempéries. Até o momento, a habitação não recebeu externamente qualquer tipo de pintura que realizasse proteção para o revestimento externo.

Também, conforme informação, as queixas dos moradores relativas a esta moradia diziam respeito ao frio intenso, durante os meses de maio a agosto, e o calor excessivo, durante os meses de novembro a fevereiro.
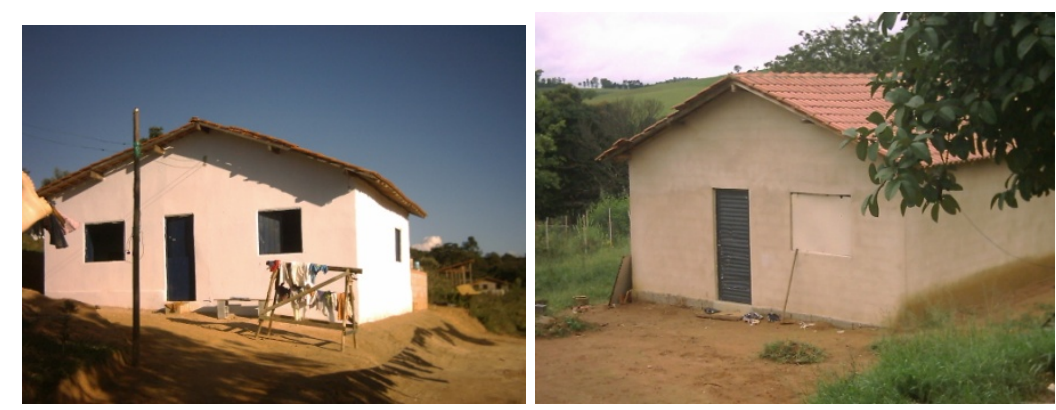

Fig. 3.15. As duas unidades avaliadas termicamente a habitação em 'Novaterra' (A) e habitação 'testemunho' (B)

O último período de análises térmicas ficou estabelecido entre os dias 04 e 21 de dezembro de 2007, quando um cômodo de uma das habitações em 'novaterra' e outro da 'habitação testemunho' já estavam forrados, possibilitando-se assim o 
estabelecimento de análises diferenciadas no que diz respeito ao comportamento térmico das duas edificações.

Quanto ao clima da região, de acordo com a classificação de W. Koeppen, Caldas se localiza em uma zona subtropical com invernos secos e verões brandos, com tipo climático Cwb-mesotérmico. O ritmo climático é caracterizado por avanços da massa Polar Atlântica.

\subsubsection{Os equipamentos de monitoramento instalado junto à Reserva Indígena}

Como afirmado anteriormente, com a conclusão da habitação de três dormitórios em ‘novaterra' é que se iniciaram os procedimentos para que fosse possível o início das avaliações térmicas. Desta maneira, foi definida em planta a localização dos sensores, tanto nesta moradia em 'novaterra', quanto na moradia 'testemunho', levando-se em consideração a Carta Solar de Caldas-MG, conforme se observa na fig.3.16. Ao todo, para a avaliação do primeiro período de análises, foram instalados oito termopares da marca $\mathrm{HOBO}$, quatro no interior de cada uma das duas edificações. O sensor externo foi instado junto a um poste de madeira, bem próximo da moradia em 'novaterra' analisada.

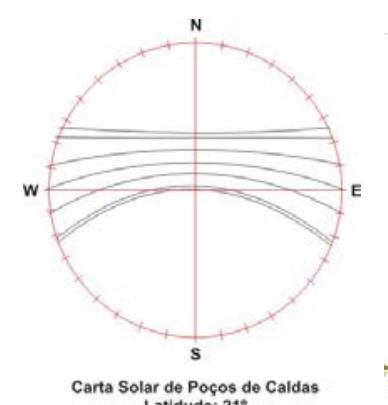

Latidude: $21^{\circ}$
Caldas

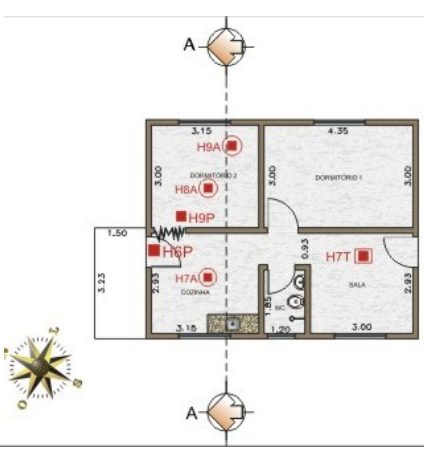

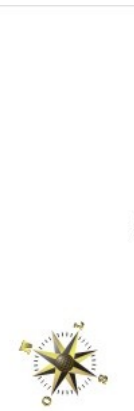

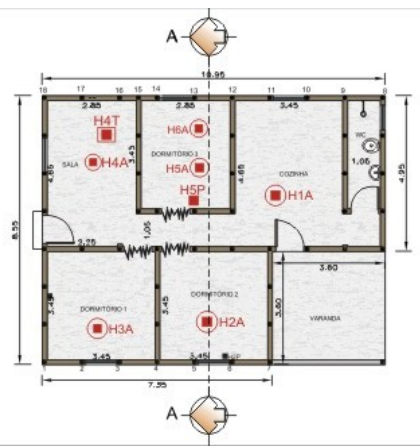

Fig.3.16. A Carta Solar, as plantas das habitações 'testemunho' (B) e 'novaterra' (A) . 
Os equipamentos utilizados durante a primeira etapa do trabalho experimental foram o HOBO 8 - HOBO H8 Loggers com um canal externo e conexão a um cabo termopar TMCX-HA HOBO. As informações registradas por estes aparelhos foram armazenadas mediante a utilização do equipamento HOBO Shuttle e processadas mediante programa computacional específico denominado Boxcar Pro 4.3, que permite a geração de gráficos com as informações colhidas diretamente a partir do próprio programa. A vantagem é que os dados são exportados para uma folha de cálculo dentro do programa Excell onde é possível assinalar o período de medições, os registros de temperatura máximos, mínimos e médios durante o tempo em que o equipamento estiver em funcionamento.

Os valores monitorados ao longo dos períodos de análises foram: a temperatura superficial interna - tsi, temperatura de bulbo seco - tbs e Temperatura do Ar - Ta, assim como a umidade relativa do ar. Seguindo orientações de VECCHIA (2001), assim como trabalhos de GIVONI e VECCHIA (2001), o intervalo adotado para cada registro foi de 30 segundos, definindo-se as totalizações por meio de médias a cada 30 minutos, em metade do tempo que recomenda a Organização Mundial de Meteorologia, ou seja, registros a cada 60 segundos, estabelecendo-se médias a cada meia hora.

Através das imagens da fig.3.17 é possível se observarem os equipamentos, respectivamente, os termopares para avaliação da temperatura superficial interna (tsi), o aparelho externo para a tomada de temperatura do ar (Ta) e os termopares para tomada de temperatura de paredes. 

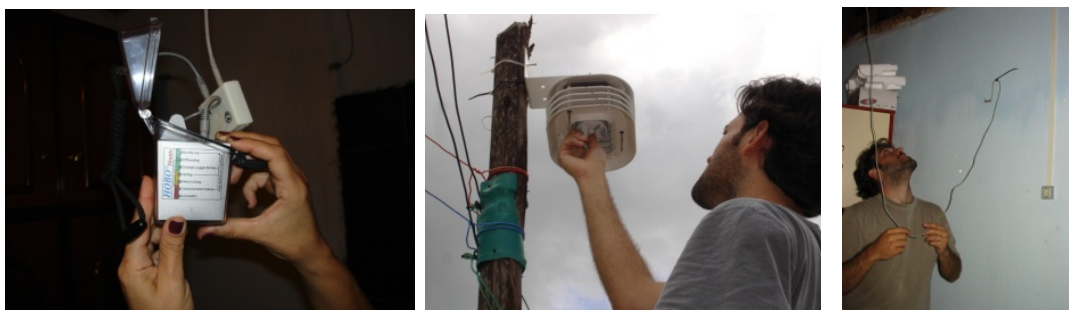

Fig. 3.17. Alguns dos equipamentos utilizados para as avaliações térmicas.

Porém, nos dois períodos posteriores, foram utilizados HOBO H8 Loggers para as medições dos ambientes internos das duas construções e, para as medições externas, foram considerados os dados fornecidos pela Estação Climatológica do Aeroporto de Poços de Caldas, de propriedade da INFRAERO, que administra este local desde 1992. O equipamento desse aeroporto é um psicrômetro marca Incotherm, modelo M/PS-01A, local distante cerca de $30 \mathrm{~km}$ da área da Reserva de Caldas. As planilhas disponibilizadas pela INFRAERO encontram-se anexas. Foram também verificados os dados da Estação Meteorológica instalada em Machado, na Escola Técnica do município, disponibilizadas pelo SIMGE/IGAM e os dados diários disponibilizados pela EPAMIG- Fazenda Experimental de Caldas, ainda que neste local, distante cerca de $5 \mathrm{~km}$ da área da Reserva, as leituras fossem processadas em períodos de tempo variáveis. Em alguns períodos específicos, a EPAMIG ${ }^{8}$ disponibilizou dados climáticos a cada meia hora.

\subsubsection{Registros de dados de temperatura}

\footnotetext{
${ }^{8}$ Como os dados climáticos relativos às temperaturas do ar em Caldas-MG foram encontrados segmentados, já que as leituras eram aferidas a cada três horas, utilizou-se a combinação de dados de três órgãos/empresas distintas, a EPAMIG-Caldas, que forneceu registros aferidos a cada três horas assim como disponibilizou dados aferidos a cada 30 minutos em dias específicos, a INFRAERO, cujos registros se iniciam no nascer e se estendem até o por do sol, aferidos a cada hora e o SIMGE/IGAM, organismos vinculados ao CPTEC/INPE, cuja Estação Climatológica esta implantada em Machado, distante cerca de $80 \mathrm{~km}$ de Caldas-MG, cujos registros aferidos apresentam variações a cada meia hora do dia.
} 
Como se percebe nas imagens apresentadas na fig. 3.18, foram instalados respectivamente nas duas habitações os sensores do tipo termopar em dois cômodos tanto para a verificação da temperatura interna do ar quanto da temperatura superficial de uma das paredes, utilizando-se, conforme já comentado, a metodologia de análise pautada na abordagem dinâmica do clima, proposta por MONTEIRO (1969) e empregada por VECCHIA (1997), que permitiu a avaliação de desempenho térmico em curto período de tempo, com maior representatividade do fato climático ${ }^{9}$.
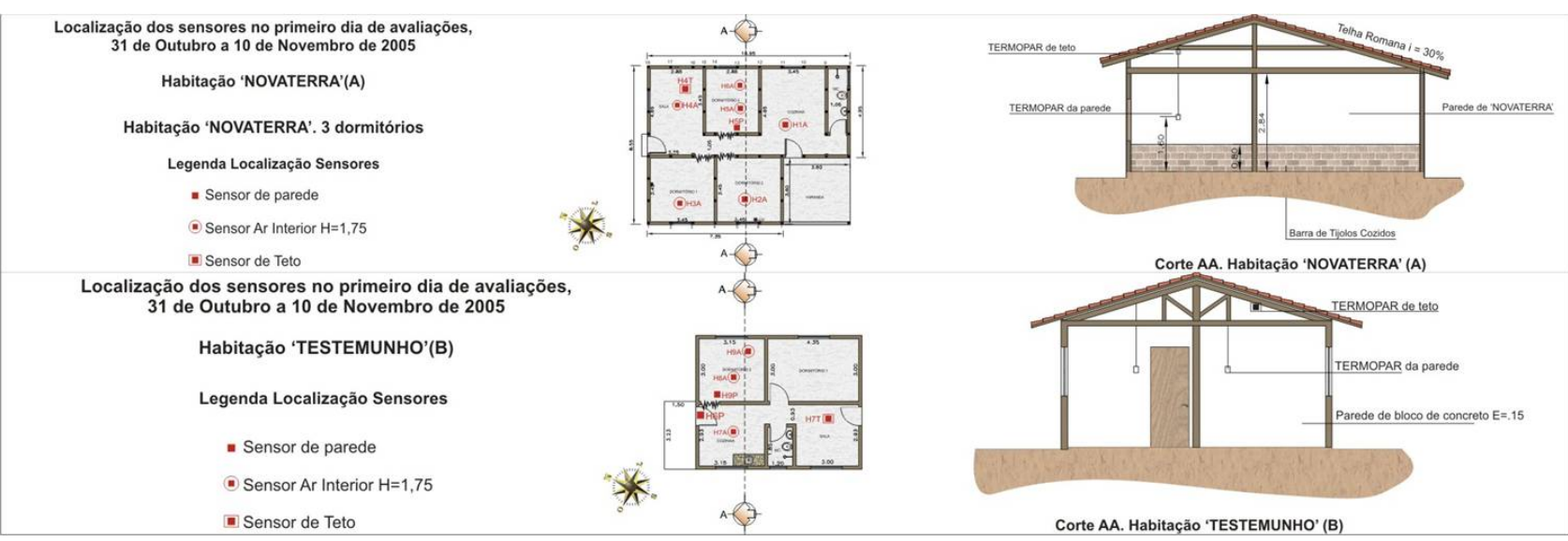

Fig.3.18. As plantas das habitações: a casa em 'novaterra' (A) e a habitação 'testemunho' (B) com a localização dos sensores.

\subsubsection{O primeiro período de avaliações}

O recorte do período de análise foi realizado a partir de dados meteorológicos coletados em superfície, conforme equipamentos discriminados anteriormente. A partir dos dados obtidos, foi realizado o delineamento de um episódio representativo

\footnotetext{
${ }^{9}$ De acordo com VECCHIA (2001), a definição de um episódio representativo do fato climático visa descrever as condições da circulação atmosférica regional vinculada aos dados climáticos tomados em superfície.
} 
do fato climático por meio do comportamento habitual de cada tipo de tempo, conforme preconiza MONTEIRO (1969).

Com a geração do gráfico de temperatura e umidade relativa do ar, pode-se observar a penetração de uma frente fria sobre a região no dia 28/10/05, aproximadamente às $16 \mathrm{~h} 30$. A entrada da frente foi notada por um pico, seguido de queda brusca dos valores de temperatura do ar e aumento significativo nos valores de umidade relativa do ar.

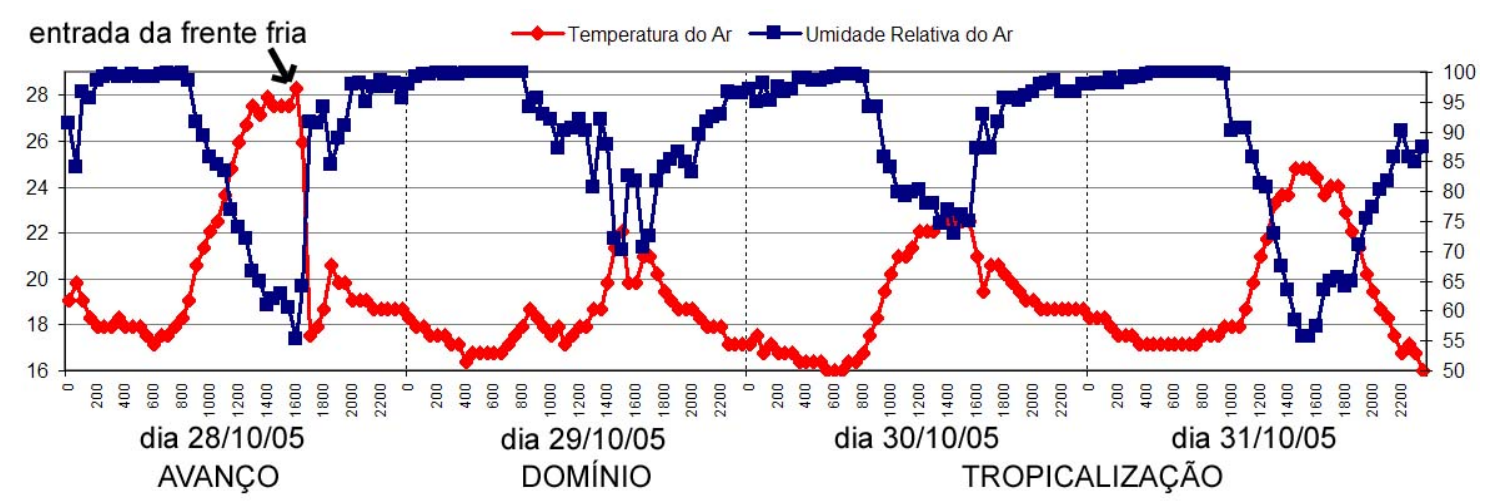

Gráfico Geral 1 - Valores de temperatura do ar $\left({ }^{\circ} \mathrm{C}\right)$ e umidade relativa do ar (\%) registrados sobre a área de análise entre os dias 28/10/05 e 31/10/05, identificado como episódio representativo do fato climático, com entrada de frente fria no dia 28, aproximadamente às $16 \mathrm{~h} 30$.

O Climanálise ${ }^{10}(2005)$ confirmou a penetração da frente fria sobre a região sul do estado de Minas Gerais no dia 28/10/05, indicando-a como a oitava frente fria a entrar no Brasil no mês de outubro. Ainda de acordo com esse boletim, as massas de ar frio atuantes sobre o Brasil no mês foram de fraca intensidade, o que justifica o curto período de domínio, de apenas um dia, apresentado no gráfico anterior.

A partir dessas análises, os dias 28, 29, 30 e 31 de outubro de 2005 foram delimitados como um episódio representativo do fato climático de primavera.

${ }^{10}$ O Climanálise é um Boletim de Monitoramento e Análise Climática do CPTEC/INPE/MTC. O papel deste Boletim, criado em outubro de 1986 é objetivo de analisar, regionalizar e documentar os eventos climáticos de maior significância, bem como a climatologia sinótica sobre o Brasil. 
Com relação aos valores de temperatura do ar, o dia 28 apresentou o valor mais elevado no episódio analisado, com máxima absoluta de $28,3^{\circ} \mathrm{C}$, às $16 \mathrm{~h} 00$ (pico que antecede a penetração da frente fria sobre a região), além de grande amplitude térmica diária $\left(11,2^{\circ} \mathrm{C}\right)$. Já o dia 29 apresentou valores moderados de temperatura do ar com reduzida amplitude diária com a temperatura mínima absoluta de $16,4^{\circ} \mathrm{C}$ e máxima absoluta de $22,1^{\circ} \mathrm{C}$, indicativo do domínio da massa Polar Atlântica sobre a região.

Vale registrar que os dias seguintes acompanharam a tendência de valores moderados de temperatura do ar, com máximas absolutas de $22,5^{\circ} \mathrm{C}$ e $24,8^{\circ} \mathrm{C}$, respectivamente. Porém, observou-se um consecutivo aumento da amplitude térmica diária $\left(6,5^{\circ} \mathrm{C}\right.$, no dia 30 ; e $8,8^{\circ} \mathrm{C}$, no dia 31$)$. Este fator é indicativo da fase de tropicalização, conforme aponta VECCHIA(1997).

\subsubsection{Interpretação dos resultados relativos ao primeiro período analisado.}

A partir dos dados disponibilizados com a utilização dos HOBOS e datalogers, foram elaboradas as análises da temperatura do ar no interior das duas edificações, respectivamente a habitação em 'novaterra'(A) e habitação 'testemunho' (B), assim como foi analisada a temperatura superficial das paredes dos cômodos onde foram afixados os termopares.

\subsection{Temperatura do ar interior}

A partir da correção dos valores de temperatura do ar no interior das duas edificações, verificou-se novamente o melhor desempenho térmico da edificação de 
'novaterra', nos quatro dias analisados. As maiores diferenças de temperatura do ar interior nas duas edificações foram registradas nos dias 28/10/05 (fase de avanço) e no dia 31/10/05 (fase de tropicalização).

A tabela 1 sintetiza os valores de temperatura do ar registrados no período analisado.

Tabela 1 - Valores de temperatura do ar no interior das duas habitações monitoradas e do ar exterior no horário de maior diferença térmica entre as duas habitações no período analisado.

\begin{tabular}{llllllll}
\hline dia & Novaterra & Bloco & Ar ext. & Ar - Nt & BI - Nt & Ar - Bl & hora \\
\hline $\mathbf{2 8}$ & 24,8 & 28,3 & 28,3 & $\mathbf{3 , 5}$ & $\mathbf{3 , 5}$ & 0 & $16 h 00$ \\
$\mathbf{2 9}$ & 19,4 & 21,3 & 19,8 & $\mathbf{0 , 4}$ & $\mathbf{1 , 9}$ & $-1,5$ & $16 \mathrm{~h} 00$ \\
$\mathbf{3 0}$ & 20,6 & 24,0 & 22,5 & $\mathbf{1 , 9}$ & $\mathbf{3 , 4}$ & $-1,5$ & $15 \mathrm{~h} 00$ \\
$\mathbf{3 1}$ & 22,1 & 25,9 & 24,4 & $\mathbf{2 , 3}$ & $\mathbf{3 , 9}$ & $-1,6$ & $16 \mathrm{~h} 00$ \\
\hline \hline
\end{tabular}

A análise diária dos resultados mostrou que, na fase de avanço, dia 28/10/05, a diferença de temperatura do ar entre as duas edificações foi de $3,5^{\circ} \mathrm{C}$, ocorrendo às 16h00, coincidindo com o horário de maior aquecimento do ar exterior. Nesse horário, a diferença de temperatura entre o ar exterior e a habitação de 'novaterra' foi de $2,7^{\circ} \mathrm{C}$, enquanto a habitação 'testemunho' encontrava-se $0,3^{\circ} \mathrm{C}$ mais aquecida que o ar exterior. Esse resultado evidencia o bom desempenho térmico da habitação em 'novaterra' frente ao calor e o mau desempenho térmico da habitação testemunho, já que a mesma agregou calor ao seu interior, estando neste momento mais quente que do lado de fora.

Na fase de domínio da massa Polar Atlântica, dia 29/10/05, a maior diferença de temperatura entre as duas habitações foi de $1,9^{\circ} \mathrm{C}$, às 16 h00. Nesse horário, a diferença de temperatura do ar exterior e da habitação em 'novaterra' foi de apenas $0,4^{\circ} \mathrm{C}$, valor insignificante quanto à sensação térmica. 
$\mathrm{Na}$ fase de tropicalização, a diferença de temperatura do ar voltou a ser significativa entre as duas habitações. No dia 30/10/05 a diferença foi de $3,4^{\circ} \mathrm{C}$, às $15 \mathrm{~h} 00$. Nesse horário, a diferença entre a temperatura do ar exterior e a temperatura do ar na habitação em 'novaterra' foi de $1,9^{\circ} \mathrm{C}$, evidenciando bom desempenho térmico da habitação. A habitação em bloco registrou, novamente, valor de temperatura do ar interna superior à temperatura do ar externa, para este mesmo horário. Esse fato mostra a inadequação desse tipo de habitação para o local da Reserva Indígena Xucuru-Kariri.

As diferenças de temperatura do ar encontradas no dia 31/10/05 foram ainda maiores. A diferença de temperatura do ar no interior das duas edificações foi de $3,9^{\circ} \mathrm{C}$, às $16 \mathrm{~h} 00$, posterior ao horário de maior aquecimento do ar exterior, que ocorreu às $14 \mathrm{~h} 30$. Esse fato pode ser explicado pela maior intensidade de radiação solar na fase de tropicalização, visto que esta fase apresenta céu claro até a aproximação de uma nova frente. Assim, o melhor desempenho da habitação em 'novaterra' deve-se à inércia térmica proporcionada pela tecnologia construtiva que emprega o barro ${ }^{11}$.

No horário de maior aquecimento do ar exterior, a diferença de temperatura do ar no interior da edificação de 'novaterra' foi de $3,5^{\circ} \mathrm{C}$, enquanto na edificação testemunho esta diferença foi nula. O gráfico 1 mostra o desempenho térmico das duas habitações com registro horário dos valores de temperatura do ar.

\footnotetext{
${ }^{11}$ MINKE (2005:38-39) comenta que uma parede maciça de barro apisionado sem palha e outros agregados leves tem quase o mesmo comportamento térmico que uma parede maciça de tijolos cozidos. Segundo este autor, o volume de ar alojado entre os poros de um material e sua umidade são relevantes para o efeito do comportamento térmico.Quanto mais leve é o material, melhor seu comportamento térmico e quanto mais úmido o material, menor é o efeito da variação de temperaturas.
} 
(a) dia 28/10/05

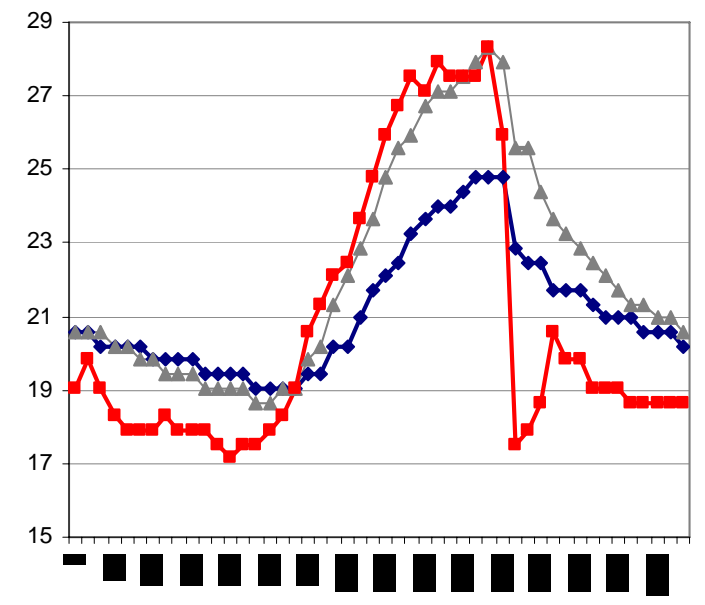

(c) dia 30/10/05

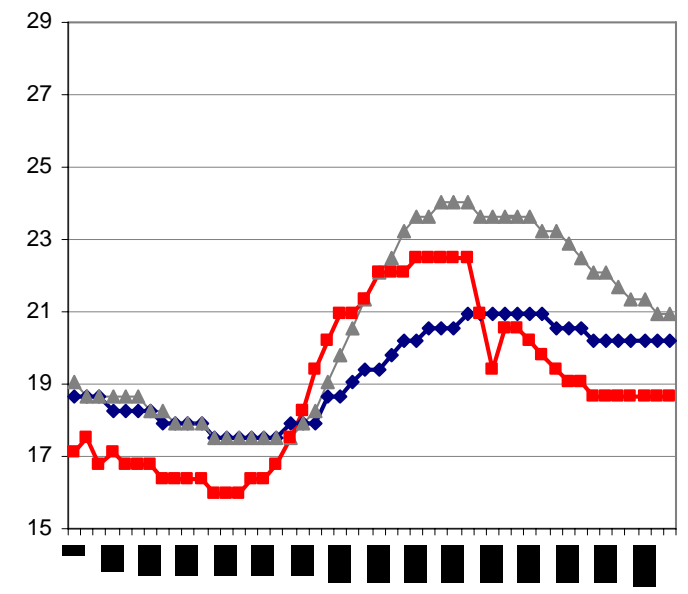

(b) dia 29/10/05

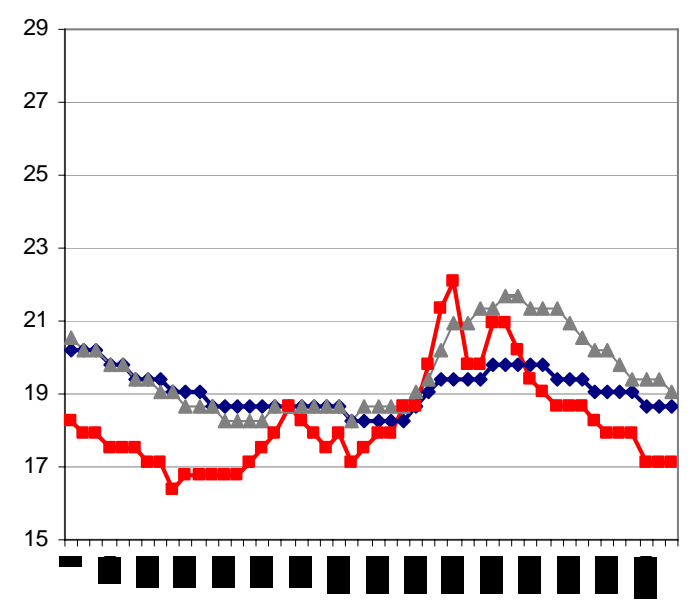

(d) dia 31/10/05

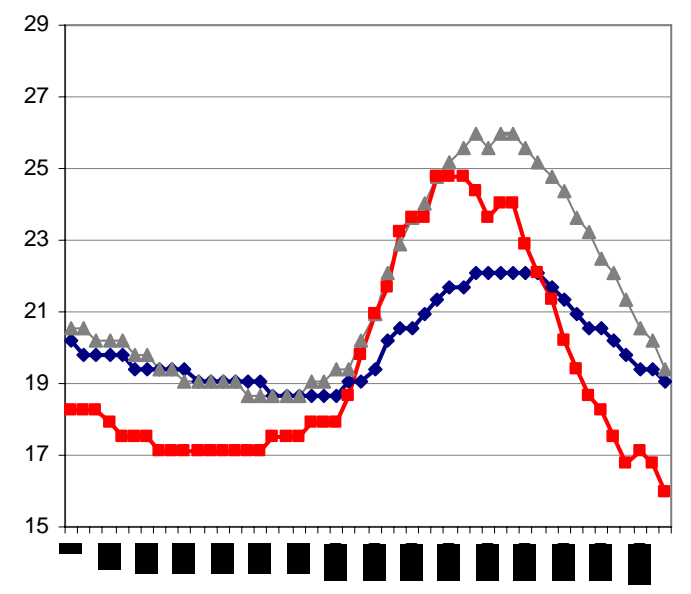

$\rightarrow$ Novaterra $\rightarrow$ Bloco $\rightarrow$-temp. ar exterior

Gráfico 1 - Comportamento térmico da temperatura do ar interior nas duas edificações monitoradas e da temperatura do ar exterior nos dias (a) 28/10/05, (b) 29/10/05, (c) 30/10/05 e (d) 31/10/05, tomados por leitura automática a cada 20 segundos, e contabilizados em média a cada 30 minutos.

\subsection{Temperatura superficial da parede}

A tabela 2 apresentada a seguir sintetiza os valores de temperatura do ar registrados no período analisado. 
Tabela 2 - Valores de temperatura superficial da parede norte das duas habitações monitoradas no horário de maior diferença térmica entre as duas habitações, no período analisado.

\begin{tabular}{lllll}
\hline dia & Novaterra & Bloco & $\begin{array}{l}\text { Bl } \\
\text { NT }\end{array}$ & hora \\
\hline $\mathbf{2 8}$ & 25,9 & 28,3 & $\mathbf{2 , 4}$ & $16 \mathrm{~h} 00$ \\
$\mathbf{2 9}$ & 20,2 & 21,7 & $\mathbf{1 , 5}$ & $15 \mathrm{~h} 00$ \\
$\mathbf{3 0}$ & 20,9 & 23,6 & $\mathbf{2 , 7}$ & $14 \mathrm{~h} 30$ \\
$\mathbf{3 1}$ & 23,2 & 26,3 & $\mathbf{3 , 1}$ & $15 \mathrm{~h} 30$ \\
\hline \hline
\end{tabular}

$\mathrm{Na}$ fase de avanço, dia 28/10/05, observou-se uma diferença significativa na temperatura superficial das duas habitações, na ordem de $2,4^{\circ} \mathrm{C}$. Esse resultado evidencia melhor comportamento térmico da 'novaterra' quanto à troca térmica por radiação entre a parede envolvente e os usuários. Esse resultado já era esperado devido à propriedade física da terra (bom isolante térmico, desde que composta de materiais leves em sua constituição).

Na fase de domínio da massa Polar Atlântica, a diferença de temperatura superficial diminuiu para ordem de $1,5^{\circ} \mathrm{C}$. Esse comportamento está ligado à redução da radiação solar direta, característica da fase de avanço, com tempo instável e encoberto.

Nos dias seguintes, na fase de tropicalização, a diferença de temperatura superficial da parede voltou a aumentar. No dia $30 / 10 / 05$ a diferença foi de $2,7^{\circ} \mathrm{C}$, chegando a $3,1^{\circ} \mathrm{C}$ no dia seguinte. Esse aumento deve-se à maior incidência de radiação solar direta nessa fase, caracterizada por céu claro. Observa-se, assim, o melhor desempenho da habitação em 'novaterra' para o período analisado. 
O gráfico 2 mostra o desempenho térmico das duas habitações com registro horário dos valores de temperatura superficial da parede.

(a) dia 28/10/05

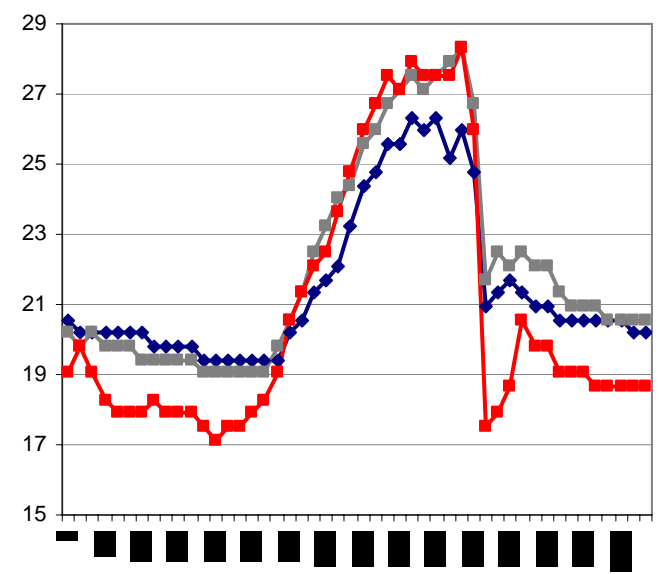

(c) dia 30/10/05

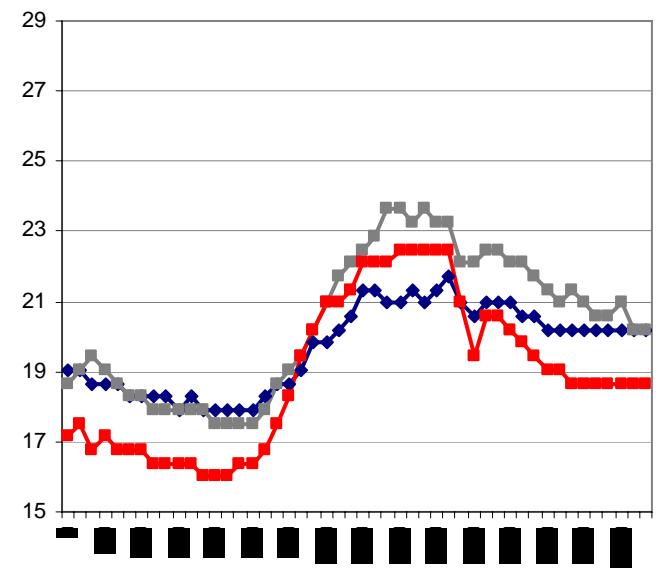

(b) dia 29/10/05

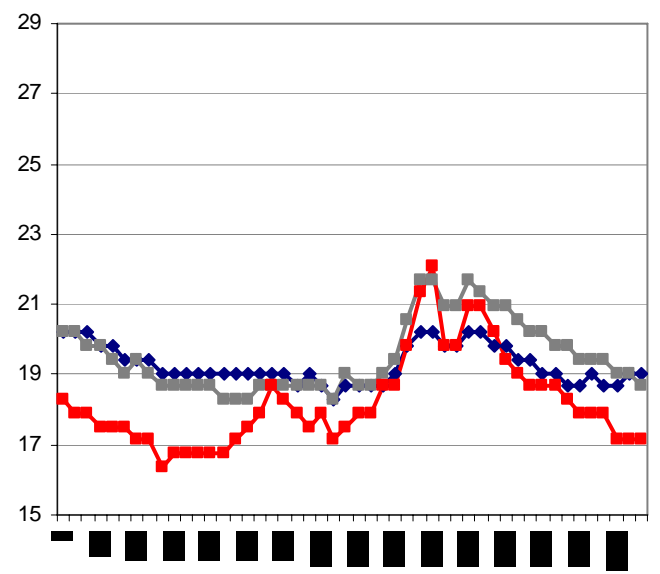

(d) dia 31/10/05

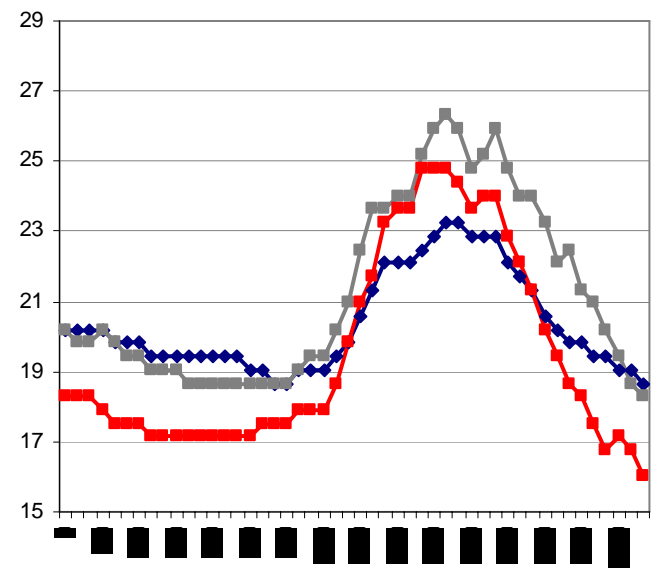

$\rightarrow$ Novaterra $\rightarrow$ Bloco $\rightarrow$ temp. ar exterior

Gráfico 2 - Comportamento térmico da temperatura superficial da parede Norte nas duas edificações monitoradas e da temperatura do ar exterior nos dias (a) 28/10/05, (b) 29/10/05, (c) 30/10/05 e (d) $31 / 10 / 05$, tomados por leitura automática a cada 20 segundos, contabilizados em média a cada 30 minutos.

A abordagem dinâmica do clima, a partir do recorte deste primeiro período representativo do fato climático, permitiu a análise satisfatória de desempenho térmico de duas habitações em curto período de tempo cronológico. 
A avaliação do comportamento térmico das duas habitações, expresso através da resposta térmica frente ao calor, evidenciou que a habitação em 'novaterra' apresenta melhor desempenho térmico que a habitação 'testemunho', demonstrando que essa tecnologia construtiva oferece condições mais favoráveis ao conforto e à habitabilidade para o clima local ${ }^{12}$.

A habitação em 'novaterra' apresentou, também, melhor desempenho quanto à análise da temperatura superficial da envolvente. Esse fato sugere que o material 'novaterra' proporciona menor troca térmica por radiação entre a envolvente e o usuário - fator de suma importância para análise de conforto térmico, embora pouco considerado nas análises de desempenho térmico de habitações.

\subsection{2.}

Os primeiros resultados relativos ao comportamento térmico das duas edificações sugerem que o sistema construtivo 'novaterra' oferece vantagens em relação ao sistema convencional, o que pode abrir espaço para outras pesquisas, no que diz respeito à utilização da terra crua em habitações rurais e/ou habitações indígenas, e porque não, para habitações urbanas.

\footnotetext{
12 Conforme estudos empreendidos por Sorre(1951), Monteiro (1969) e Vecchia (1997), as temperaturas interiores tendem a acompanhar o ritmo exterior das temperaturas do ar. Este padrão interior de temperaturas também foi reconhecido por Givoni (1998), que o descreveu como um padrão cíclico diário, onde o conjunto da radiação solar junto da temperatura exterior determina a relação com as temperaturas interiores do ar nas edificações. Tais trabalhos referendam, desde 1997, a demonstração que o clima em regiões de médias latitudes segue um padrão de encadeamento sucessivo de sistemas atmosféricos, os chamados tipos de tempo meteorológicos. Porém, não se pode deixar de mencionar também que são três os principais componentes construtivos que determinam a relação entre os valores da temperatura do ar exterior e da radiação solar com o comportamento dos valores de temperatura interior das edificações: o piso, as paredes e o teto. No caso específico da presente pesquisa, os dois primeiros episódios analisados possuem uma condição distinta do terceiro episódio, ou seja, tanto em 2005 quanto em 2006 as unidades de habitação analisadas não possuíam forro. Assim, dados consideráveis, relativos à atenuação da temperatura interna somente poderão ser observados no terceiro período de análises, que ocorreu em 2007.
} 
Deve-se salientar que o emprego das tecnologias de terra por vezes necessita ser adaptado e melhorado para que seja compatibilizado ao contexto local onde tal tecnologia será inserida. Ao mesmo tempo, para efetivamente representarem resultados, conforme aponta MINKE (2005), é importante que a terra esteja combinada com fibras naturais e outros agregantes, pois, quanto mais leve a composição da argamassa de terra, melhor será o seu comportamento térmico. As tabelas apresentadas na fig.3.19 extraídas de (MINKE:2005 e FATHY:1986 apud MINKE) reforçam tal afirmação.

A primeira tabela aponta o equilíbrio do conteúdo de umidade em diferentes tipos de materiais, com destaque para o comportamento dos blocos de terra argilosos (3) e blocos de terra limosos (4). Já a segunda tabela mostra um gráfico de comparação de temperaturas interiores e exteriores em um ambiente construído com adobe (curva superior) e em ambiente construído com elementos pré-fabricados de concreto (curva inferior) elaborado por Hassan Fathy em 1986.

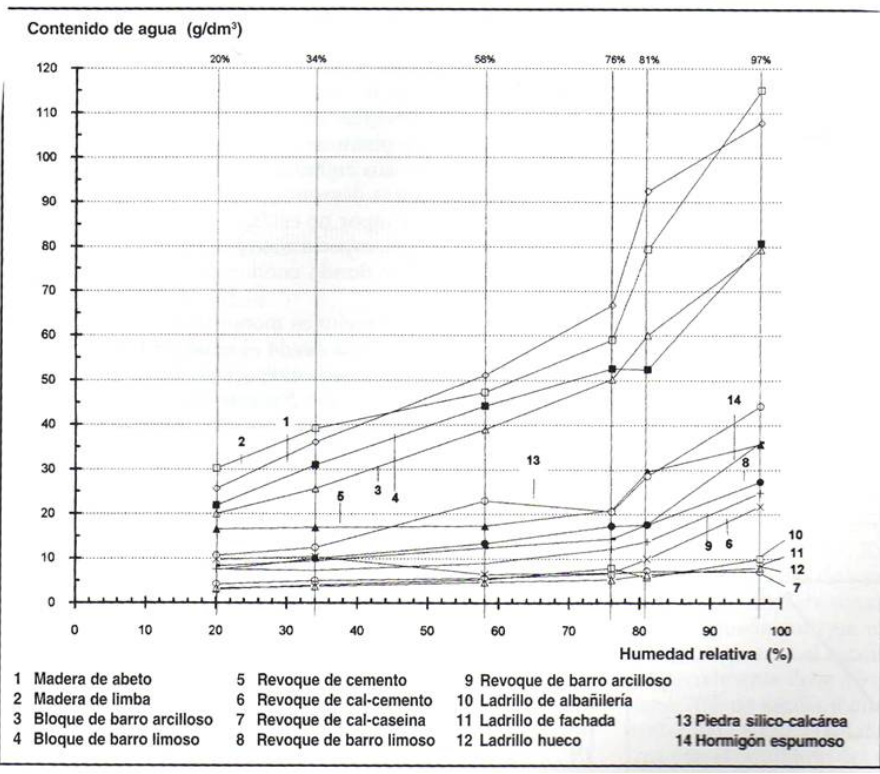

Fig.3.19. $1^{\mathrm{a}}$ tabela. Equilíbrio de umidade em diferentes materiais e $2^{\mathrm{a}}$ tabela. Desempenho térmico exterior e interior de edificações construídas em terra e em concreto.
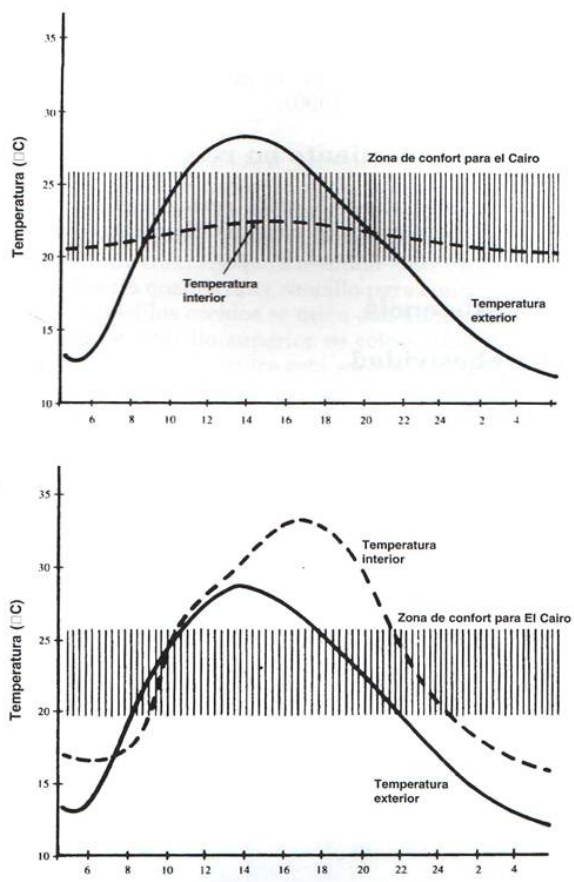

Comparación de temperaturas interiores y exteriores de una construcción con bóvedas de adobe (arriba) en relación a una construida con elementos prefabricados de hormigón (abajo) (Fathy, 1986) 


\subsubsection{O segundo período de avaliações.}

Da mesma forma que no período anterior, a partir dos dados obtidos, foi realizado o delineamento de um episódio representativo do fato climático por meio do comportamento habitual de cada tipo de tempo, conforme preconiza MONTEIRO (1969).

Foi realizado um recorte no período de análise em virtude do comportamento térmico em três dias que foram caracterizados no gráfico a seguir em função da grande amplitude térmica ocorrida durante esses dias.

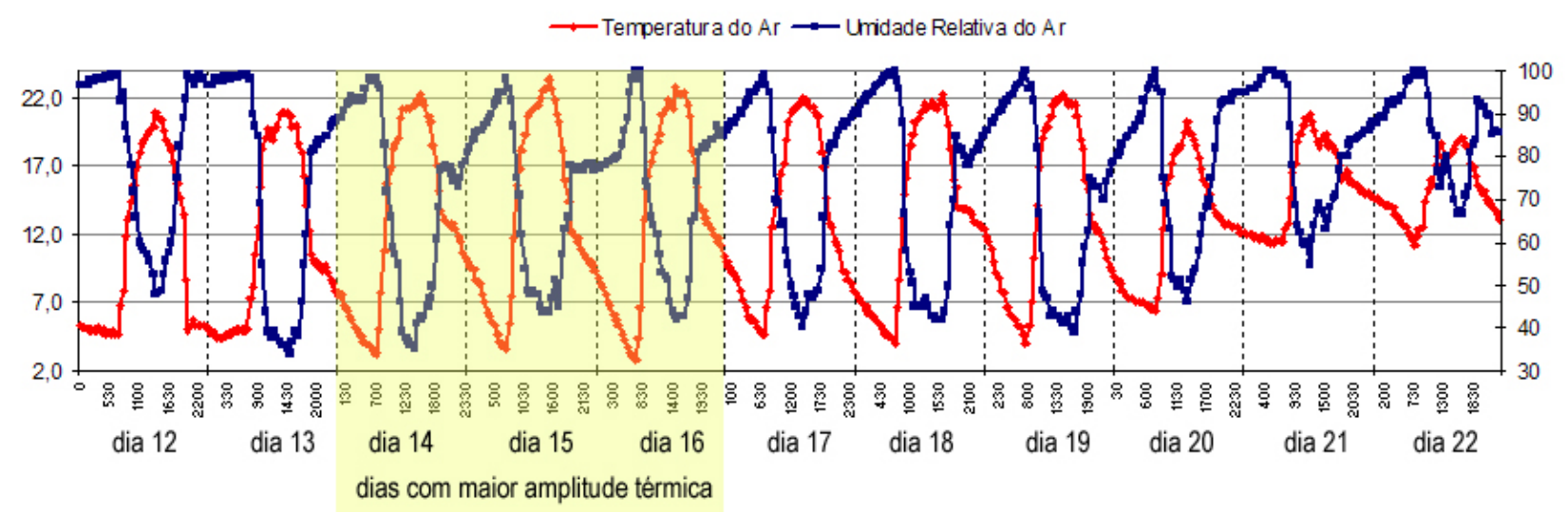

A partir dos dados da estação meteorológica, observa-se o domínio de uma vigorosa massa Polar Atlântica sobre a região em estudo, a qual imprime baixos valores de temperatura do ar.

Como informado, foram os dias 14, 15 e 16 de maio de 2006 que apresentaram maior amplitude térmica diária. No dia 14, os valores de temperatura do ar registrados foram: $22,3^{\circ} \mathrm{C}$, máxima absoluta; $3,3^{\circ} \mathrm{C}$, mínima absoluta; com amplitude térmica diária de $19^{\circ} \mathrm{C}$.

Os valores registrados no dia 15 foram: $23,4^{\circ} \mathrm{C}$, máxima absoluta; $3,6^{\circ} \mathrm{C}$, mínima absoluta; com amplitude térmica diária de $19,8^{\circ} \mathrm{C}$. No dia 16 , os valores registrados foram: $22,8^{\circ} \mathrm{C}$, máxima absoluta; $2,9^{\circ} \mathrm{C}$, mínima absoluta; com amplitude térmica diária de $19,9^{\circ} \mathrm{C}$. As máximas absolutas foram registradas no horario de $15 \mathrm{~h}$, nos 
dias 14 e 15, e às 14:30h, no dia 16. As mínimas foram registradas às $7 \mathrm{~h}$, nos três dias escolhidos para a análise.

Assim, esses três dias em tela foram tomados como os dias típicos experimentais para análise de desempenho térmico das habitações frente ao frio por apresentarem menores mínimas absolutas e maiores amplitudes térmicas, ambas em escala temporal diária.

Com os dados disponibilizados após a utilização dos HOBOS e datalogers, também no segundo período, ou seja, entre 11 e 31 de maio de 2006, foram elaboradas as análises da temperatura do ar no interior das duas edificações, respectivamente a habitação em 'novaterra'(A) e habitação 'testemunho' (B), assim como foi analisada a temperatura superficial das paredes dos cômodos onde foram afixados os termopares. Neste momento havia apenas dois HOBOS disponíveis para cada habitação. A localização dos pontos de colocação dos sensores nas duas casas foi apresentada na fig. $\mathbf{3 . 1 8 .}$

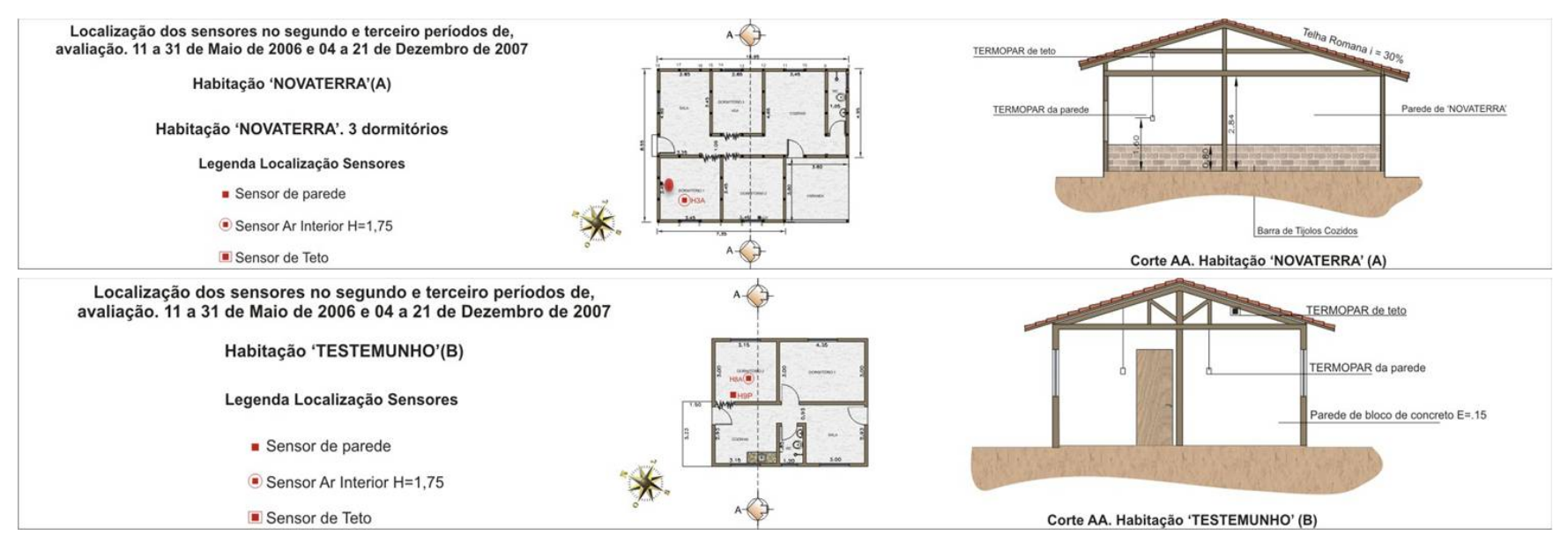

Fig. 3.20. Sensores do $2^{\circ}$ episódio. Superior: habitação em 'novaterra'(A) e inferior: habitação testemunho (B). 


\subsubsection{Interpretação dos resultados relativos ao segundo período analisado.}

A correlação dos valores de temperatura do ar no interior das duas habitações permite, mais uma vez, comprovar o melhor desempenho térmico da habitação em 'novaterra'13 frente ao frio, nos três dias analisados. As diferenças de temperatura do ar no interior das duas edificações foram similares durante todo o período.

A tabela 1.2 apresenta os valores de temperatura do ar registrados no período analisado.

Tabela 2.2 - Valores de temperatura do ar $\left({ }^{\circ} \mathrm{C}\right)$ no interior das duas habitações monitoradas e do ar exterior no horário de maior diferença térmica entre as duas habitações no período analisado.

\begin{tabular}{cccccccc}
\hline dia & Novaterra & Bloco & Ar ext. & $\begin{array}{c}\text { Ar - } \\
\text { NT }\end{array}$ & $\begin{array}{c}\text { Bl - } \\
\text { NT }\end{array}$ & $\begin{array}{c}\text { Ar - } \\
\text { Bl }\end{array}$ & hora \\
\hline \hline $\mathbf{1 4}$ & $9,3^{\circ} \mathrm{C}$ & $4,7^{\circ} \mathrm{C}$ & $4,2^{\circ} \mathrm{C}$ & $-\mathbf{- 5 , 1 ^ { \circ } \mathrm { C }}$ & $-4,6^{\circ} \mathrm{C}$ & $-0,5^{\circ} \mathrm{C}$ & $4 \mathrm{~h} 30$ \\
$\mathbf{1 5}$ & $7,8^{\circ} \mathrm{C}$ & $3,4^{\circ} \mathrm{C}$ & $3,6^{\circ} \mathrm{C}$ & $-4,2^{\circ} \mathrm{C}$ & $-4,4^{\circ} \mathrm{C}$ & $0,2^{\circ} \mathrm{C}$ & $7 \mathrm{~h} 00$ \\
$\mathbf{1 6}$ & $10,1^{\circ} \mathrm{C}$ & $6,4^{\circ} \mathrm{C}$ & $5,3^{\circ} \mathrm{C}$ & $-4,8^{\circ} \mathrm{C}$ & $-3,7^{\circ} \mathrm{C}$ & $-1,1^{\circ} \mathrm{C}$ & $4 \mathrm{~h} 00$ \\
\hline \hline
\end{tabular}

A análise dos resultados demonstra que no primeiro dia do período em que ocorreu a maior amplitude térmica a diferença de temperatura do ar entre as duas edificações foi de $5,1^{\circ} \mathrm{C}$, ocorrendo às $04 \mathrm{~h} 30$. Mais uma vez os resultados evidenciam o bom desempenho térmico da 'novaterra', agora frente o frio e o mau desempenho do bloco de concreto.

Observando-se o gráfico 1.2, pode-se verificar o desempenho térmico das duas habitações com o registro horário dos valores de temperatura do ar.

\footnotetext{
${ }^{13}$ Ainda que os episódios analisados correspondam a períodos do ano distintos, fica evidente tanto no primeiro quanto no segundo episódios o melhor desempenho da edificação construída em terra.
} 
(a) dia 14/05/06

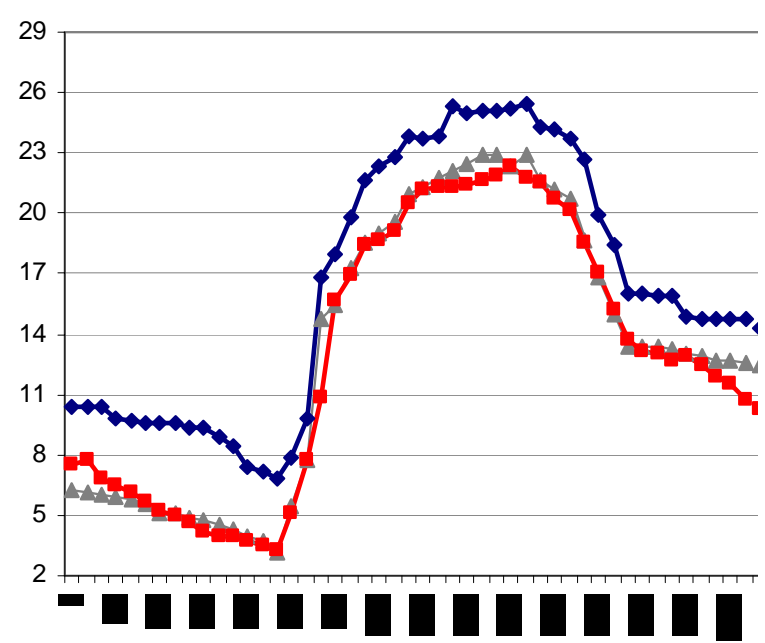

(b) dia 15/05/06

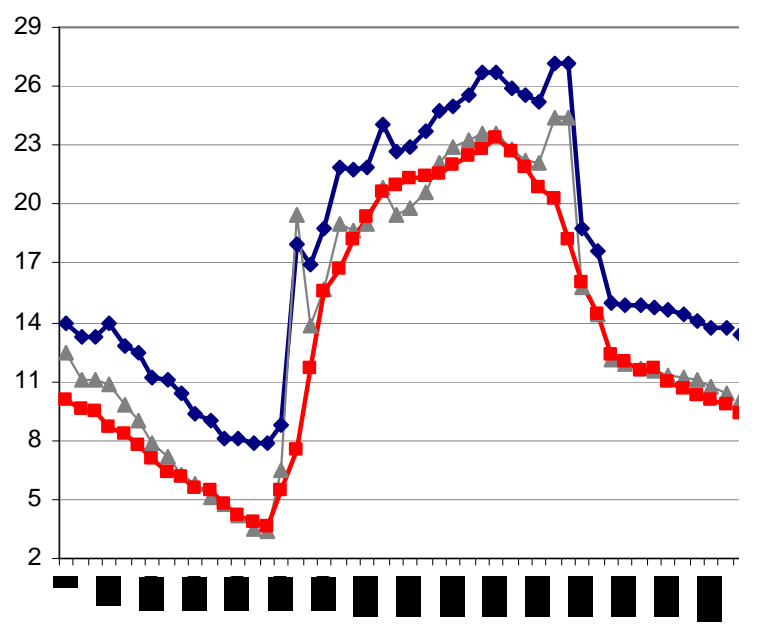

(c) dia 16/05/06

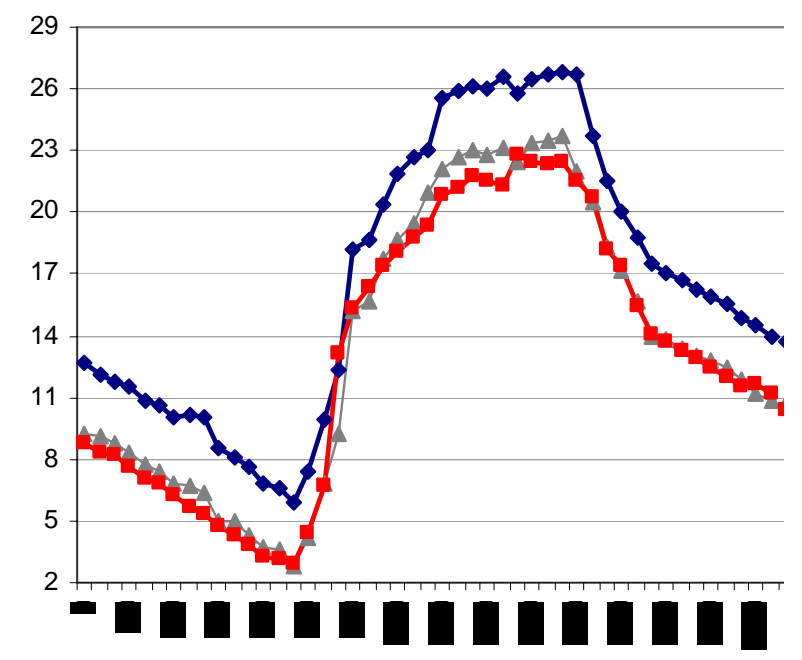

$\rightarrow$ Novaterra $\rightarrow$ Bloco $\rightarrow$ temp. ar exterior

Gráfico 1.2 - Comportamento térmico da temperatura do ar interna nas duas edificações monitoradas e da temperatura do ar exterior nos dias (a) 14/05/06, (b) 15/05/06 e (c) 16/05/06, tomados por leitura automática a cada 20 segundos, contabilizada em média a cada 30 minutos.

Durante os três dias analisados, fica evidente o bom desempenho térmico da ‘novaterra' frente o frio, apontando para a diferença significativa, ocorrida no dia 15/05/06 entre o desempenho desse material comparado ao do bloco, no horário de maior aquecimento do ar no interior da edificação, ou seja, às 16:00h, quando a diferença entre os dois materiais foi de $4^{\circ} \mathrm{C}$. 


\subsection{Temperatura superficial da parede.}

No que diz respeito à temperatura superficial da parede, analisando-se as duas habitações observou-se uma diferença expressiva na temperatura da ordem de $4,8^{\circ} \mathrm{C}$. Particularmente no dia $15 / 05 / 2006$, a diferença de temperatura superficial foi registrado em dois horários distintos, como mostra a tabela 2.2. Este resultado evidencia, mais uma vez, o melhor comportamento térmico da "novaterra" quanto à troca térmica por radiação entre a parede envolvente e o usuário. O resultado já era esperado devido à propriedade física do barro (bom isolante térmico), conforme MINKE (2005).

A tabela 2.2 sintetiza os valores de temperatura do ar registrados no período analisado.

Tabela 2.2 - Valores de temperatura superficial $\left({ }^{\circ} \mathrm{C}\right)$ da parede Norte das duas habitações monitoradas no horário de maior diferença térmica entre as duas habitações no período analisado.

\begin{tabular}{ccccc}
\hline dia & Novaterra & Bloco & Bl - NT & hora \\
\hline \hline $\mathbf{1 4}$ & $9,5^{\circ} \mathrm{C}$ & $4,7^{\circ} \mathrm{C}$ & $-\mathbf{- 4 , 8 ^ { \circ } \mathrm { C }}$ & $4 \mathrm{~h} 30$ \\
$\mathbf{1 5}$ & $12,7^{\circ} \mathrm{C}$ & $7,9^{\circ} \mathrm{C}$ & $-\mathbf{4 , 8 ^ { \circ } \mathrm { C }}$ & $3 \mathrm{~h} 00$ \\
$\mathbf{1 5}$ & $8,2^{\circ} \mathrm{C}$ & $3,4^{\circ} \mathrm{C}$ & $-\mathbf{4 , 8 ^ { \circ } \mathrm { C }}$ & $7 \mathrm{~h} 00$ \\
$\mathbf{1 6}$ & $12,1^{\circ} \mathrm{C}$ & $6,9^{\circ} \mathrm{C}$ & $-\mathbf{- 5 , 2 ^ { \circ } \mathrm { C }}$ & $8 \mathrm{~h} 00$ \\
\hline \hline
\end{tabular}

Da mesma forma, quando o objeto de análise do comportamento térmico são as paredes, fica evidente o melhor desempenho térmico da 'novaterra' frente o frio. A maior diferença registrada no período analisado equivale à $5,2^{\circ} \mathrm{C}$, ocorrida no dia 16 às 8 h00.

O gráfico 2.2 mostra o desempenho térmico das duas habitações com registro horário dos valores de temperatura superficial da parede. 
(a) dia 14/05/06

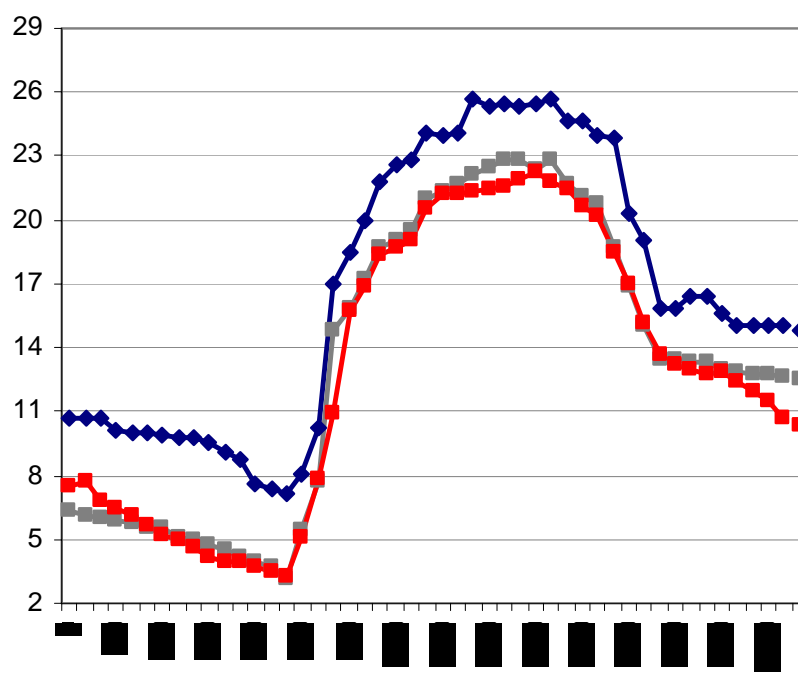

(b) dia 15/05/06

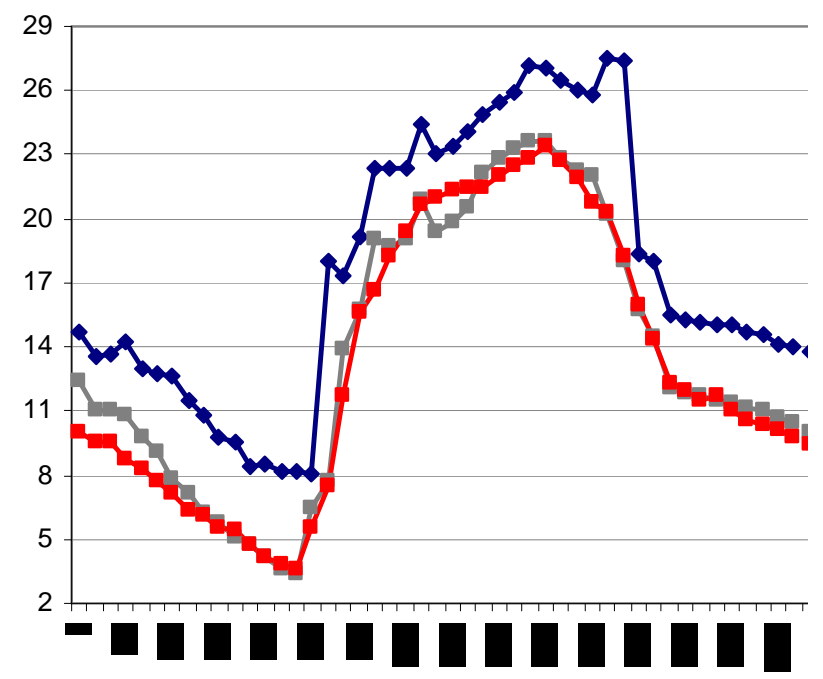

(c) dia 16/05/06

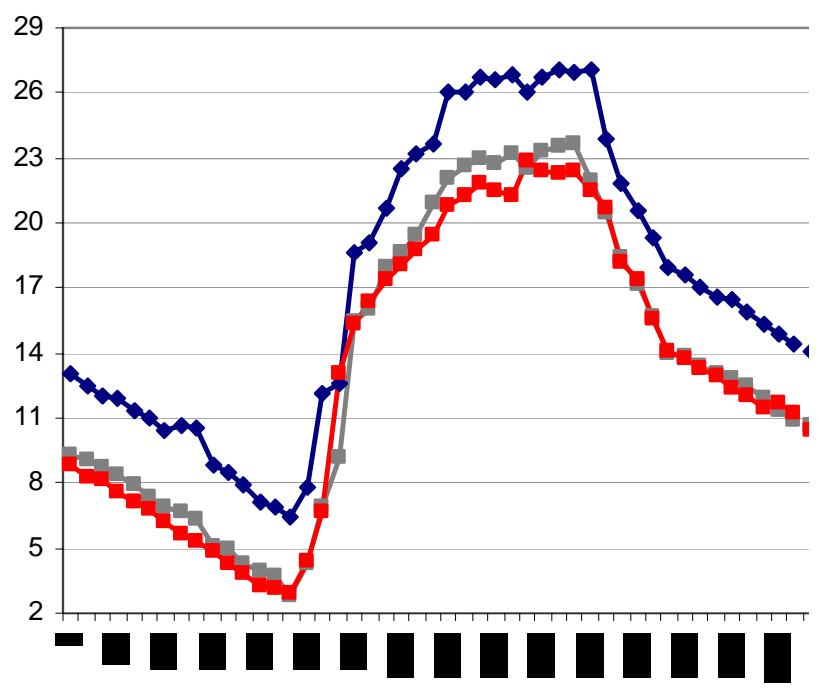

$\longrightarrow$ Novaterra $\longrightarrow$ Bloco $\rightarrow$ temp. ar exterior

Gráfico 2.2 - Comportamento térmico da temperatura superficial da parede Norte nas duas edificações monitoradas e da temperatura do ar exterior nos dias (a) 14/05/06, (b) 15/05/06 e (c) 16/05/06, tomados por leitura automática a cada 20 segundos, contabilizada em média a cada 30 minutos.

Reforçando o anteriormente exposto, a avaliação do comportamento térmico das duas habitações, expressa por meio da resposta térmica frente o frio, reforça o atributo da terra como um material que proporciona um conforto térmico interessante, demonstrando, mais uma vez, que essa tecnologia adaptada oferece condições favoráveis ao conforto e à habitabilidade para o clima de Caldas. 


\subsection{Resultados do segundo período de Avaliações Térmicas.}

Depois de terem sido realizadas avaliações em períodos distintos de dois anos subseqüentes junto a duas habitações implantadas no mesmo local, a Reserva de Caldas, comprova-se efetivamente as vantagens que o sistema construtivo ‘novaterra’ oferece em relação ao sistema construtivo convencional.

\subsection{Resultados Experimentais Gerais}

As análises térmicas em períodos diferentes possibilitaram a leitura de situações climáticas bastante diversas e o desempenho térmico tanto da habitação de 'novaterra'(A), quanto da habitação 'testemunho'(B), bem peculiar em cada um dos episódios.

A expressiva diferença apresentada entre os resultados obtidos para a habitação em 'novaterra' e os resultados para a habitação 'testemunho', resultado da comparação em períodos diferentes durante três anos, acaba reforçando a afirmação de MINKE(2005) sobre a questão do comportamento térmico da terra, aliada aos conceitos anteriormente estabelecidos por SORRE(1951), OLGYAY(1963), VECCHIA (1997) e GIVONI(1998) acerca do comportamento térmico de edificações.

A habitação 'testemunho', como pode se perceber desde o primeiro período de análises, apresenta um desempenho térmico inferior àquele obtido durante os períodos avaliados para a habitação em 'novaterra', ficando claro que o emprego de blocos de concreto para a área da Reserva Xucuru-Kariri de Caldas é totalmente inadequado. 
Os resultados das análises térmicas comprovaram, experimentalmente, que a maior dificuldade dos índios que diz respeito aos períodos mais frios pode ser atenuada com a presença do forro, porém não eliminada.

No entanto, há que se considerar para os dois casos o aspecto de que os índios acabam, como já apontado durante a pesquisa "lacrando" as aberturas, demonstrando de forma simples a dificuldade de adaptação que possuem em relação ao clima da Reserva Xucuru-Kariri de Caldas. Recentemente, o Cacique José Sátiro afirmou, que de maneira geral, a única dificuldade que os Xucuru-Kariri sentem em relação a Caldas diz respeito ao frio. Estão satisfeitos em relação à propriedade, à proximidade da "rua", (a cidade), têm na área possibilidades tanto para o cultivo quanto para pastagens, há na área locais destinados aos seus rituais étnicos e religiosos. Porém, infelizmente, o frio os incomoda muito.

Outro aspecto que deve ser destacado no contexto das análises térmicas diz respeito à execução do forro para as habitações: decididamente, a presença do forro exerce um papel significativo para os dois tipos de edificações, possibilitando um desempenho térmico mais eficiente para os dois tipos de construções analisadas, porém, com uma qualidade ampliada para a habitação em ‘novaterra'. 


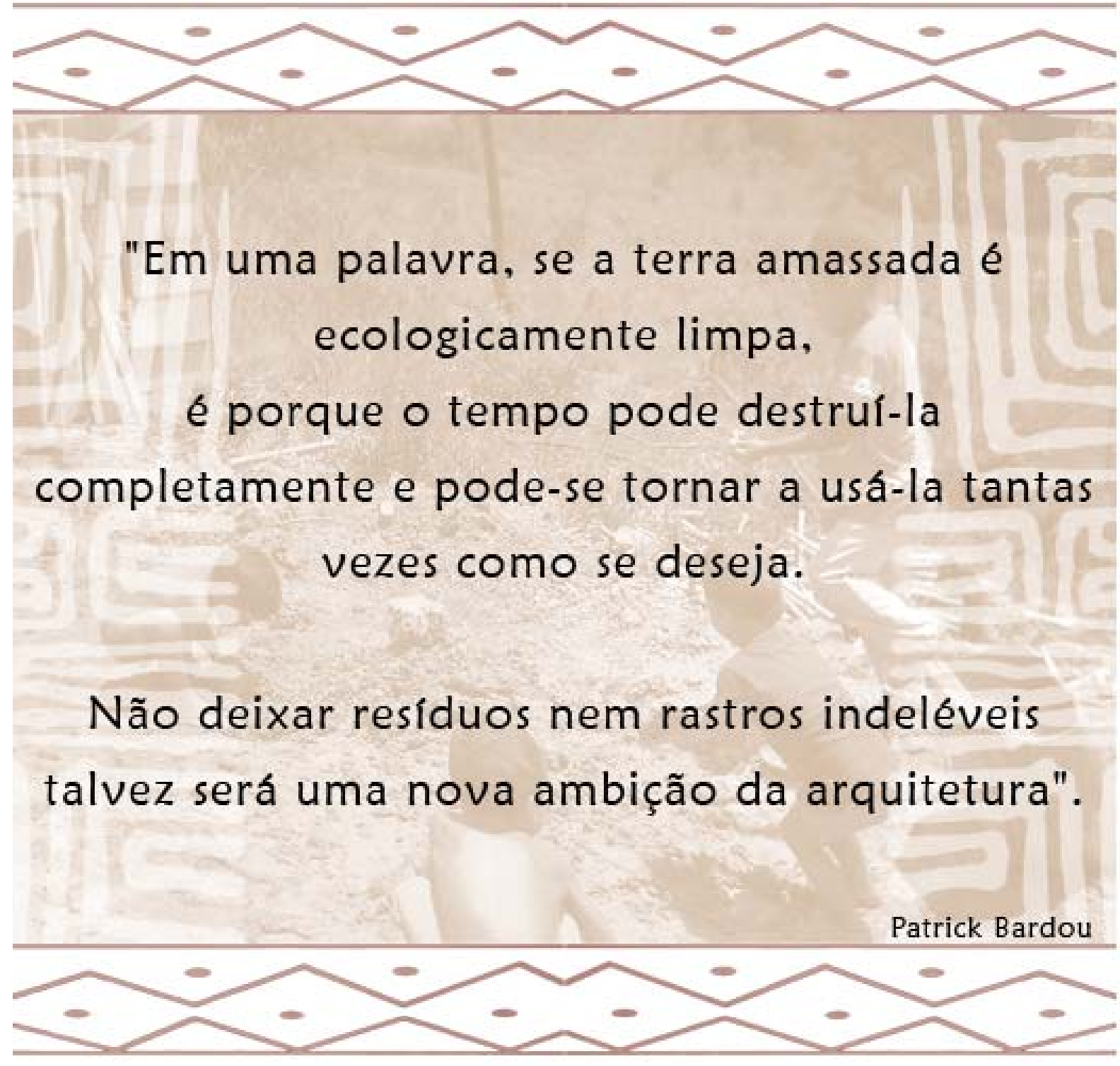

\section{Discussão}

Neste capítulo se realiza uma síntese de todos os resultados obtidos na pesquisa, sejam resultados de caráter conceitual, histórico, antropológico ou sociológico, sejam resultados experimentais.

A partir dos mesmos são realizadas as discussões e a comparação com resultados obtidos em trabalhos realizados por outros autores. Porém, será possível constatar 
que os objetivos desta pesquisa, quando se observa o material bibliográfico pesquisado, são extremamente diversos na maior parte das vezes.

A discussão se pautará na análise de dois parâmetros: o percurso do grupo indígena estudado e suas habitações.

No que diz respeito ao percurso e remanejamento do grupo estudado, verifica-se que a primeira localidade para onde os índios foram deslocados pela FUNAI, ainda que não contentasse o grupo Xucuru-Kariri, deixou poucas lembranças e se fez necessária essa mudança em conseqüência do confronto estabelecido entre as famílias Celestino e a família Sátiro do Nascimento.

Não foram encontrados na literatura outros casos de remanejamento recentes e extensos. Ou seja, não se encontraram remanejamentos de grupos que, em período de tempo relativamente curto, como o período gasto pelo grupo Xucuru-Kariri, passassem por três estados diferentes e por regiões geográficas, culturais, econômicas tão diversas. Os remanejamentos documentados por ALMEIDA E SILVA (2004); LADEIRA (2006); CARVALHO (2005-2006), GRUPIONI (2006) ocorreram por questões de conflitos fundiários entre agricultores e indígenas, ou decorrentes da instalação de barragens e/ou Usinas Hidrelétricas, assim como por causa da instalação ou ampliação de atividades de mineradoras e, por último, entre os motivos mais comuns, por questões de conflitos relativos à demarcação de terras.

O caso do remanejamento do grupo Xucuru Kariri é bastante particular e merece um estudo aprimorado por parte da Antropologia Social, da Sociologia e da História, 
entre outras disciplinas diretamente ou indiretamente vinculadas ao campo das Ciências Sociais. Dentre os trabalhos encontrados merece destaque aquele relatado por LADEIRA (2006) que comenta a reaproximação ocorrida entre os índios Guarani do Norte do Brasil daqueles índios Guarani afixados nas regiões sudeste e sul.

$\mathrm{Na}$ verdade, a matriz étnica é a mesma, mas um grande grupo de índios Guarani deixou a região Sul, após a Guerra do Paraguai e se dirigiu para o norte do país, em direção ao mar de Belém. A reaproximação entre os grupos somente começou a ocorrer entre 1988 e 1989 e vem proporcionando, segundo a autora, "a revitalização de formas gestual e lingüística para os índios ora fixados na Região Norte e, para aqueles que estão no Sul, a memória dos "ensinamentos" guardados pelos antigos integrantes do grupo que se dirigiu para a região Norte, que é fonte de sabedoria e revigora a sua própria experiência".

Ainda que a questão do remanejamento dos Xucuru-Kariri seja decorrente de problemas intra-étnicos, quem sabe poderá ocorrer um dia a reaproximação entre os grupos Xucuru, visando o renascimento de uma língua há muito tempo extinta e a construção de uma identidade caracterizada em seus rituais, em seu artesanato, em seus hábitos culinários e, por que não, em suas moradias.

Outro aspecto a ser abordado diz respeito, essencialmente, às pesquisas sobre habitação indígena no Brasil. Conforme observado no decorrer deste trabalho, há poucas pesquisas que tratem da habitação indígena sob os aspectos arquitetônicos, histórico-arquitetônicos e construtivos. Dentre essas se destacadam a pesquisa de SÁ(1982), assim como os trabalhos de MALHANO(1988) e de NOVAES(Org.) 
(1983). Ao longo dos últimos anos, infelizmente, a atuação da FUNAI relativa à preservação das habitações e da memória cultural indígena tem deixado muito a desejar. Já afirmava Villas Boas sobre o papel da FUNAI, em entrevista de 2001: "é possível verificar a continuidade no estado de abandono das aldeias, sobretudo daquelas que se localizam na faixa litorânea ou gravitam à margem de grandes centros urbanos, como é o caso das aldeias do Jaraguá e Parelheiros aqui em São Paulo. Esses são exemplos de uma pseudo-política integracionista que não integra ninguém, apenas desestrutura e excluí".

Faz-se urgente e necessário um esforço que articule organismos de proteção aos povos indígenas, organizações não- governamentais, universidades e pesquisadores a fim de que o pouco que resta da diversificada história da arquitetura e construções indígenas possa ser mapeado, resgatado e preservado.

Do ponto de vista do melhoramento e adaptação tecnológica realizada na tecnologia da taipa de mão / pau-a-pique brasileiro, como uma releitura do bajareque mejorado, a 'novaterra' acaba cumprindo um importante papel: ao se conceber uma tecnologia protegendo a argamassa de terra armada, o esqueleto e o entramado, a 'aparência' da edificação se aproxima do aspecto geralmente encontrado no contexto regional do sudeste brasileiro, onde está inserida a reserva de Caldas. Ou seja, se for realizada uma análise das edificações rurais e urbanas de todo o Sul de Minas, a grande maioria delas possui argamassa de revestimento (reboco) e não se apresenta de forma inacabada ou destruída, tal como as edificações de taipa de mão ou pau-a-pique encontradas, tanto no sul de Minas, quanto no agreste alagoano, local de onde vieram os índios Xucuru-Kariri. 
Sobre este aspecto, conforme aponta BORSÓl (2008), as moradias do Cajueiro Seco referenciadas por este trabalho foram concebidas com um revestimento de reboco e caiadas. Além de proteger melhor a taipa, a caiação possibilitava a manutenção preventiva por parte dos moradores, tal como implementado na proposta das habitações indígenas desta pesquisa. As habitações do Cajueiro Seco podem ser observadas na fig.4.01.

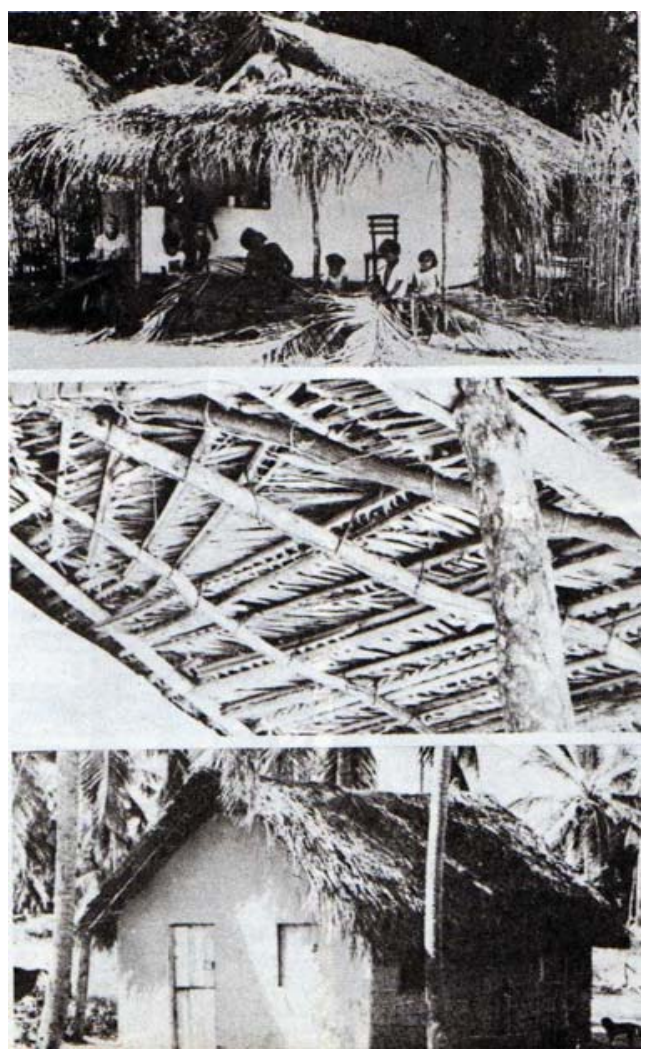

Fig. 4.01. Dois momentos distintos das casas da comunidade do Cajueiro Seco, em Jaboatão do Guararapes, na região metropolitana da Recife:

A primeira foto, uma das casas de taipa proposta por Borsói já caiada e na imagem inferior, uma das casas rebocadas porém, sem a proteção de tintas.

Da mesma forma, conforme se verifica através do trabalho de FERRAZ (1992/1996) cuja imagem é apresentada na fig. 4.02, as edificações da Serra da Mantiqueira relatadas apresentam revestimento, o mesmo ocorrendo nas propostas do bajareque mejorado de GONZÁLES (2002) e CASTAÑEDA(2001), propostas que podem ser observadas através da fig. 4.02 e 4.03.. 
4. DISCUSSÃo 146

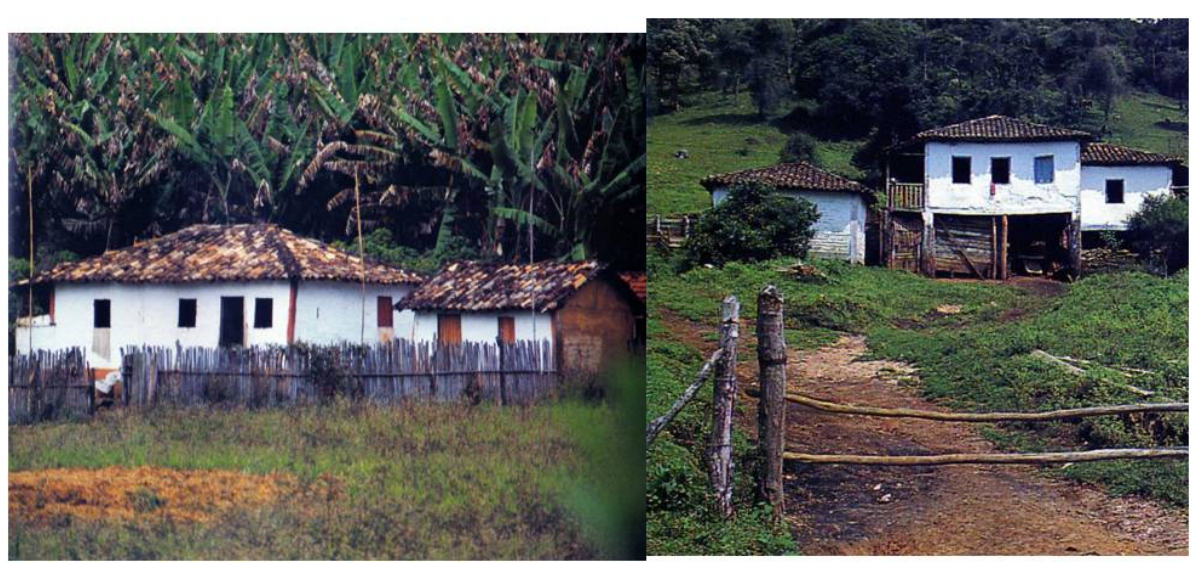

Fig.4.02. A exposição das colunas de madeira nas casas rurais da Serra da Mantiqueira-MG

Verificando a proposta da 'novaterra' e comparada a esses exemplares, a única diferença reside no fato de que nas habitações Xucuru toda a estrutura de madeira foi revestida, conforme solicitação dos índios, diferentemente daquilo que ocorrera nos exemplos apontados pelas figuras 4.02 e 4.03 .

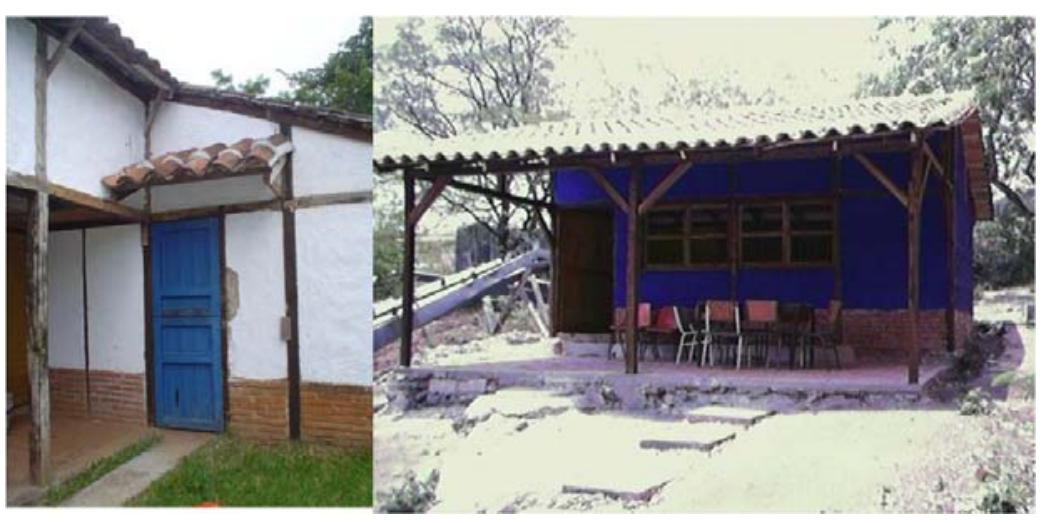

Fig. 4.03. As casas de bajareque mejorado em Chiapas, no México.

Assim, para o contexto da habitação indígena Xucuru-Kariri, a 'novaterra' não só se apresenta como uma tecnologia mais eficiente, quando comparada a uma tecnologia convencional, como também se apresenta como uma tecnologia menos estigmatizada no que diz respeito a associação comum da taipa de mão ou pau-apique à pobreza. 
Quanto ao aspecto relativo à metodologia empregada para a concepção das habitações realizadas na Reserva Xucuru-Kariri de Caldas, conforme apontado, ocorreram problemas na compreensão por parte dos índios de como seriam executadas as suas moradias, assim como a resistência desse grupo relativa ao aprendizado de uma nova tecnologia, adaptada e contextualizada às necessidades e anseios do grupo. Recentemente, em contato com os Xucuru-Kariri de Caldas, membros do grupo foram questionados sobre os motivos que não estariam construindo outras habitações em 'novaterra' e, em seu lugar, novamente estavam repetindo a tecnologia da taipa de mão. A resposta foi simples e imediata: "é mais fácil construir com taipa".

Os trabalhos de CASTAÑEDA (2004 e 2007) apontam aspectos interessantes para uma metodologia que facilite a compreensão e o envolvimento da comunidade. $\mathrm{O}$ tema das estratégias metodológicas que envolvam comunidades é abordado de maneira interessante no livro "Arquitectos de La comunidad. El método", do arquiteto argentino Rodolfo Livingston, assim como no trabalho de PEYLOUBET e MASSUH (2001).

Desta forma, a pesquisa chama atenção para a importância de se elaborarem estratégias e atividades de integração quando forem realizados trabalhos práticos que envolvam comunidades de baixa renda, comunidades rurais ou grupos excluídos.

Somente a partir de uma efetiva parceria entre os agentes envolvidos, as pesquisas de caráter prático poderão ter sucesso assegurado. 
Outro meio de facilitar a compreensão, além da elaboração das estratégias metodológicas, é a elaboração de cartilhas e manuais ilustrados e com linguagem acessível, como por exemplo a Cartilha disponibilizada por SILVEIRA \& GAMA (2005) no site desse escritório de arquitetura, ou o manual "Mi casa de bajareque" e "Manual de Autoconstrucción. Aula rural de Bajareque" de GONZÁLES(2004, 2005) além dos trabalhos de CASTAÑEDA e ALBORES (2005).

Por esta razão, como já apontado, a presente pesquisa apresenta como contribuição o material denominado "Construção com 'novaterra'. Guia de procedimentos e dicas para autoconstrução", disponibilizado nos anexos e em arquivo do tipo pdf, a fim de que possa ser utilizado em trabalhos de natureza prática ou acadêmicos, assim como possa ser utilizado pelos Xucuru-Kariri de Caldas. A capa do Guia “Construção em ‘novaterra'” pode ser observada na fig. 4.04.

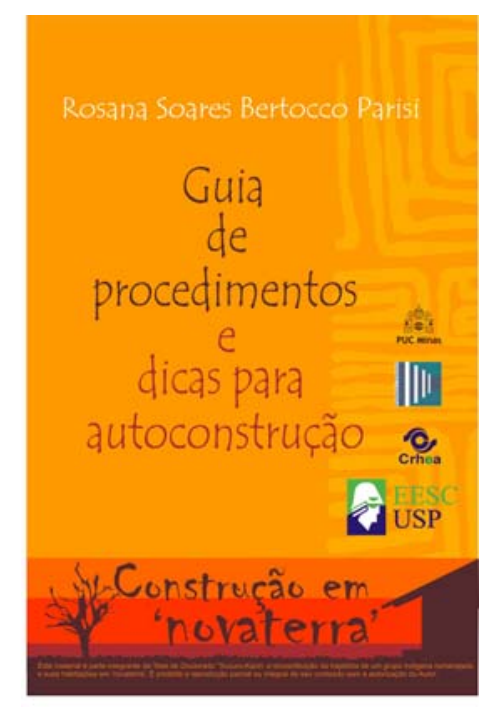

Fig. 4.04. A proposta da capa do Guia de procedimentos: "Construção em 'novaterra'.

Também é importante destacar os aspectos comentados relativos à reprodutibilidade da 'novaterra', à possibilidade de industrialização dos painéis-esqueleto para a 'novaterra' e ao projeto da estrutura de madeira para a edificação utilizada como 
referência no trabalho. O próprio manual, há pouco comentado é um elemento que auxiliará o processo de reprodução da tecnologia adaptada da 'novaterra'.

Porém, além deste elemento, o projeto da estrutura de madeira com o detalhamento de cortes e aproveitamento das peças faz parte dos anexos da pesquisa, a fim de que se promova a facilidade da racionalização do processo construtivo. Sobre o aspecto da racionalização e da industrialização de componentes da 'novaterra', a pesquisa apontou a 'quincha préfabricada' e aos vários elementos que fazem parte da proposta do Cajueiro Seco de BORSÓı (1963,1982).

Assim como nos dois exemplares mencionados, existe a possibilidade da reprodução de componentes da 'novaterra', em especial, o painel-esqueleto, que pode ser reproduzido de forma semelhante à quincha préfabricada, ou a proposta do Cajueiro Seco. As aberturas - janelas e portas - de forma semelhante poderão ser reproduzidos em série, de acordo com a modulação adotada para a 'novaterra'. Por último, elementos como caixa-d'água e forro, especificamente a subcobertura, também apresentam possibilidades de reprodução em série para a racionalização do processo produtivo, sem deixar de ser uma proposta ecológica e sustentável.

Este trabalho, se analisado sob o aspecto da disseminação de uma tecnologia adaptada e a reprodutibilidade da mesma, abre espaço para novas pesquisas e projetos, visando o seu aprimoramento para que, sempre que necessário, seja empregada sem deixar de levar em consideração as condicionantes locais. 
Como discussão, um outro aspecto que deve ser apontado diz respeito às análises térmicas para as habitações de 'novaterra'. Entre as referências da literatura pesquisada sobre análise e desempenho térmico, via de regra, foram encontradas apenas simulações e metodologias para a sua realização, como pode se observar nos trabalhos de AMORIM e MINAKI (2005), GHISI, LAMBERTS et al.(2003), LUCAS, ALBARRACIN e CARESTIA (2002), FERRAZ JR.(1995), SIQUEIRA, AKUTSU.M. et al (2005), BARBOSA e LAMBERTS (2001), entre outros.

O número de pesquisas que trabalham situações reais é inferior àquelas em que se utilizam simulações, Dos trabalhos em que se empreenderam análises em edificações construídas, podem ser citadas a pesquisa de CARLETTO (2005), que trabalha comparações para sistemas de cobertura, de VECCHIA e SILVA(2001), que analisam o desempenho de cobertura em que se utilizou a subcobertura de tetrapak, o trabalho de SILVA(2005), em que o autor analisou sistemas de cobertura implantadas pelo Programa 10x10 em San Francisco de los Baños, em Cuba, entre outras.

Pode ser também destacada a pesquisa realizada por VECCHIA, MONTORO e SILVA et al.(2001), em Cuba onde analisaram o desempenho térmico de um conjunto de habitações. Já VECCHIA, GIVONI e SILVA (2001), desenvolveram uma outra proposta em que analisaram o desempenho térmico de coberturas em Descalvado-SP. Merecem destaque ainda as pesquisas de CASTAÑEDA (2003, 2005), onde foram analisados o desempenho térmico de sistemas alternativos de cobertura, assim como o trabalho de PARISI, CASTAÑEDA et al $(2006,2007)$ em que se estabeleceram correlações entre o desempenho térmico de habitações construídas em terra no México e no Brasil. 
Se a busca for feita especificamente dos trabalhos em que foram avaliados o desempenho térmico de edificações construídas empregando as tecnologias de terra, o número cai ainda mais. Sobre este tema, foram apenas encontradas referências nos trabalhos realizados por FERRAZ JR.(1995), ainda que esse seja essencialmente teórico e nas pesquisas realizadas por CASTAÑEDA (2003), PARISI, CASTAÑEDA et al $(2006,2007,2008)$, anteriormente mencionadas, o que acaba por abrir uma perspectiva para novas pesquisas relativas ao desempenho térmico das habitações em terra crua.

Além disso, a 'novaterra', como foi constatado ao longo desse trabalho, é uma tecnologia sustentável, que dialoga com o contexto local, procurando empregar a terra como material predominante e totalmente reincorporado ao meio e que pode ser realizada sem a necessidade de mão- de- obra especializada.

Ainda que o objetivo do trabalho não tenha sido analisar a redução de custos das habitações indígenas, tal fato acabou ocorrendo: enquanto a edificação 'testemunho' (B) custou à comunidade religiosa de São Pedro de Caldas, que a patrocinou, $\mathrm{R} \$$ 21000,00 para os cerca de 54 m2 de construção, ou seja, R\$390,00/ m2 (trezentos e noventa reais por metro quadrado), a edificação em 'novaterra' custou $R \$ 9400,00$ para os seus 93 m2 de área construída, isto é, $\mathrm{R} \$ 101,00 / \mathrm{m} 2$ (cento e um reais por metro quadrado), demonstrando que o custo da 'novaterra' é interessante porque se concretiza através do sistema de autoconstrução ou mutirão.

Ainda no que se refere aos custos, é importante salientar que, o que aconteceu na Reserva de Caldas não deve servir de referência porque, em função do local onde 
no futuro a tecnologia for implantada, em função das facilidades ou dificuldades de acesso, das oscilações de preço dos materiais industrializados, entre outros aspectos, pode fazer com que haja um aumento ou a diminuição no valor por metro quadrado da tecnologia empregada.

No que diz respeito à implantação da 'novaterra' em outros locais, a recomendação para o emprego dessa tecnologia está vinculada à importância da análise preliminar das condicionantes climáticas e geográficas do lugar (variações de temperatura, intensidade e direção dos ventos, intensidade de chuvas, entre outros aspectos). Estas devem, conforme apontado por OLGYAY (1963) estar relacionadas a uma concepção projetual que leve em consideração todas as condicionantes climáticas e, por conseqüência, também as térmicas de cada lugar.

Quando se fala na 'novaterra', há dois pontos importantes que não podem ser esquecidos: um diz respeito à elaboração de uma metodologia de trabalho pelo grupo multiplicador dessa tecnologia de terra. Além disso, deve ocorrer o treinamento, o conhecimento, o convencimento e o envolvimento da comunidade que utilizará tal tecnologia acerca das vantagens e benefícios que a mesma pode proporcionar. Conforme apontado por MINKE (2005) e por MILANEZ(1958), a reprodutibilidade equivocada de tecnologias de terra pode desencadear um maior preconceito em relação ao uso da terra como material de construção. Percebe-se então ser fundamental o conhecimento da tecnologia, o treinamento e envolvimento do grupo que irá reproduzi-la e disseminar a mesma. LIVINGSTON (2004) aborda a questão da metodologia no livro "Arquitectos de la comunidade". 
Por essas razões, fica expressa a importância do encarte que acompanha o presente trabalho denominado "Construções em 'novaterra': guia de procedimentos e dicas para autoconstrução", no sentido de que este material poderá se configurar como um meio de orientação para que se evitem problemas futuros quanto ao desempenho e sobrevivência da edificação construída com a 'novaterra'.

No que diz respeito a proposta de utilização da 'novaterra' para os Xucuru-Kariri, apesar de o emprego da terra nas edificações estar relacionado às origens das habitações do grupo e ser uma prática recorrente, os índios não atribuem nenhuma importância à conservação e manutenção da habitação. Neste sentido, talvez seja interessante o fomento de atividades de educação ambiental não só para as crianças da Reserva como também para as famílias Xucuru, a fim de que entre as mesmas seja despertada a consciência acerca da preservação e durabilidade das edificações. Porém, este aspecto extrapola a proposta da presente pesquisa e poderá ser desenvolvido em outros trabalhos correlatos.

Quanto às possibilidades de disseminação e reprodutibilidade da tecnologia, reforçase a importância do conhecimento e envolvimento do grupo que irá executá-la.

Quando se pensa na reprodutibilidade da tecnologia adaptada da 'novaterra' em sistemas de mutirão auto-gestionários, torna-se fundamental, além da importância do projeto arquitetônico, a importância do projeto da estrutura de madeira que estará voltado à redução do número de peças, ao aprimoramento de cortes, emendas, encaixes, aspectos que colaboram para a integridade estrutural da edificação. Importante salientar que experiências já realizadas como a quincha pré-fabricada, 
anteriormente apresentadas por este trabalho devem ser consideradas quando o objetivo for a construção de um conjunto de habitações em 'novaterra'.

No entanto, é importante não só o conhecimento e o envolvimento do grupo que executará a tecnologia adaptada, mas o estabelecimento de procedimentos metodológicos eficazes. Conforme apontam PEYLOUBET e MASSUH (2001) "se recomenda para os projetos e investigações o desenvolvimento e a transferência tecnológica com certo rigor metodológico que coloque os objetos produzidos em um estado de verificação, que permita determinar a validade da estratégia adotada como motor do desenvolvimento comunitário local a partir da satisfação e envolvimento do grupo objetivo, como um marco da ação sustentável em termos de cuidado e respeito ao ambiente natural, a riqueza cultural e a qualidade para o habitat popular".

Ao final dessa discussão, reafirma-se um aspecto pouco comentado: ainda que não seja este o objetivo da presente pesquisa, se não houver um conjunto de ações e estratégias que modifiquem o quadro instituído no que diz respeito aos índios, lamentavelmente, dentro de um curto espaço de tempo, nada ou quase nada restará do legado que possa reconstruir um segmento da identidade de uma cultura essencialmente brasileira e, por que não, indígena.

\subsection{Contribuições e possibilidades do melhoramento de outros tipos de habitações com a utilização da 'novaterra'.}

Afirmou-se inicialmente que a intenção deste trabalho era discutir não somente a habitação indígena, mas também a habitação em terra como possibilidade de reprodução e melhoria para as moradias das áreas rurais. 
Tais melhorias poderiam se reproduzir também em áreas urbanas, destinando-se às moradias de interesse social, uma vez que o emprego da terra e, em especial, da 'novaterra', além de possibilitar a autoconstrução e não necessitar de mão-de-obra especializada, possibilita, por seu caráter modular, que a edificação possa se construir em etapas, de acordo com o planejamento e os recursos financeiros de cada proprietário. Faz-se, no entanto, necessário o conhecimento de princípios básicos, também já mencionados anteriormente, além da orientação dos trabalhos com diretrizes e recomendações indispensáveis para facilitar e aperfeiçoar os projetos e as construções com a terra.

No concurso denominado: "Prêmio Caixa / IAB 2004 - Concurso Nacional de Idéias para Habitação Social no Brasil (categoria profissional)" - intitulado Programa de Subsídio para a Habitação de Interesse Social, divulgado em 17 de dezembro de 2004, foi premiado um projeto modular que propunha a utilização de painéis em terra em unidades de habitação de $45 \mathrm{~m} 2$, a serem implantadas em Salvador-BA. A equipe vencedora, originária de Porto Alegre-RS, foi composta por Letícia Teixeira Rodrigues, Carolina Hartmann Galeazzi e Gustavo Jaquet Ribeiro.
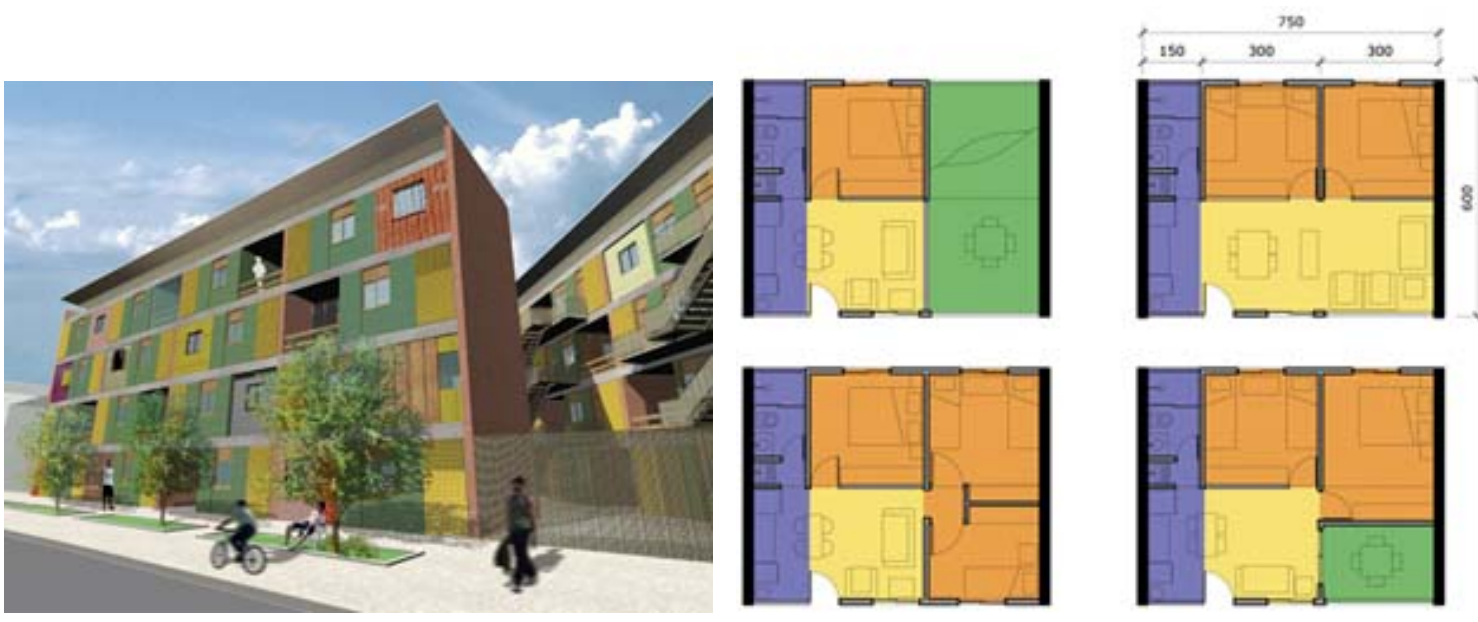

Fig. 4.05a. Imagens da proposta vencedora do prêmio Caixa/IAB 2004. 


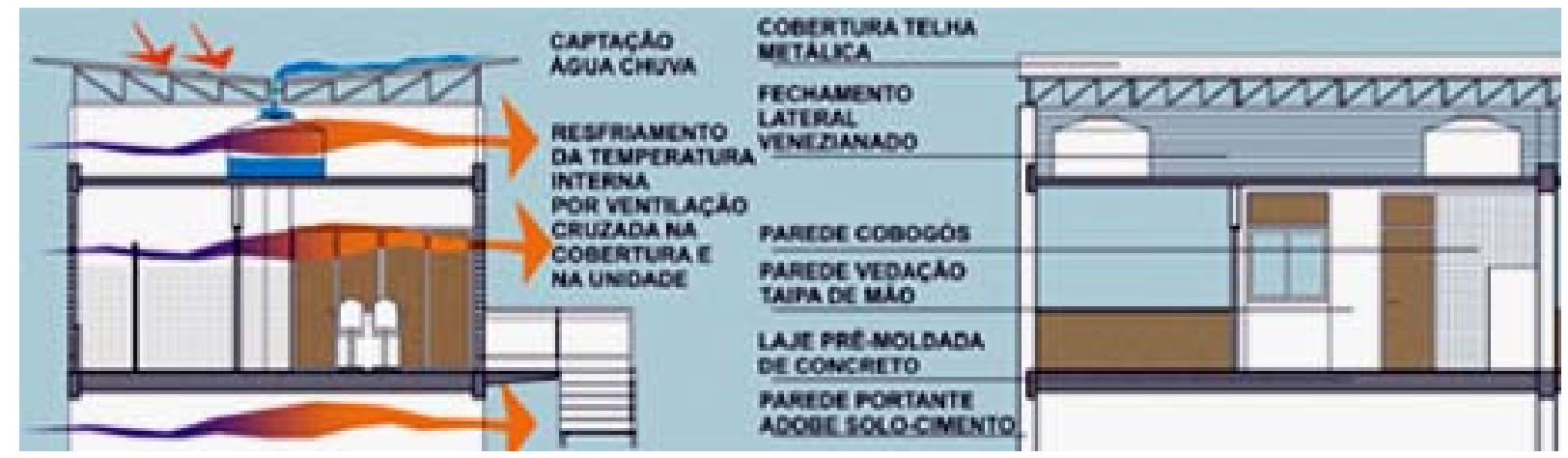

Fig. 4.05b. Imagens da proposta vencedora do prêmio Caixa/IAB 2004.

Tal proposta, bastante inovadora diante de outras apresentadas no mesmo concurso, foi divulgada, porém não implantada, em função de alguns fatores:

1. A resistência à utilização da terra e adoção da mesma como um material natural, nobre e sustentável para a construção civil perpassa por questões já apontadas por este trabalho: a terra é associada à pobreza.

2. Em segundo lugar, há uma pressão "invisível" por parte dos cartéis / monopólios do cimento e de outros materiais de construção convencionais amplamente utilizados que aliados ao lobby das empreiteiras, das construtoras e dos interesses políticos, regulam o mercado da construção para habitações de interesse social.

Até o presente momento, diferentemente das posturas que se estruturam em outros países do continente latino-americano, como Colômbia, Venezuela e Chile, por exemplo, o Brasil ainda reluta em se desvincular dos sistemas construtivos tradicionais que, além de gerarem grandes desperdícios de materiais e serviços, colaboram para o comprometimento da qualidade do meio ambiente. Na década de 1960, Lina Bo Bardi, comentando a proposta do Cajueiro Seco de BORSÓI (1963), afirmava: 
"Um dos poucos exemplos nacionais de pesquisa realista à respeito da casa própria é ainda hoje o trabalho realizado em Pernambuco pelo arquiteto Acácio Gil Borsói, em 1963. Saindo dos problemas de contingência social que orientavam o Centro da Cultura Popular do recife, o assunto Habitação Mínima foi enfrentado, não do ponto de vista idealístico-formal (tipo proposta de habitação em matéria plástica,quando ainda não há produção industrializada de matéria plástica ou de elementos pré-moldados de concreto quando ainda não há produção suficiente de cimento: soluções queridas em geral pelos teóricos abstratos do problema da Casa Popular, mas, saindo de uma realidade existente, mesmo se, para isto, fosse necessário renunciar, por parte do arquiteto, a resultados formalmente atraentes e modernos para chegar, dentro de uma renúncia profissional decidida à priori, a um "quase" limite arquitetônico: o princípio da auto-ajuda e a melhoria progressiva diretamente ligada aos fatores econômicos".

Lina Bo Bardi. Apresentação da proposta da comunidade do Cajueiro Seco. in Revista Acrópole $n^{\circ} 5$. Texto gentilmente cedido pelos arquitetos Acácio Gil Borsói e Tereza Borsói.

As principais vantagens para o uso da terra em habitações de interesse social, em primeira análise, são: a facilidade e rapidez de construção; o baixíssimo consumo de energia; a fartura de matéria-prima (há ainda muita terra disponível no país); a mãode-obra que, necessariamente, não precisa ser especializada, apenas conscientizada e previamente treinada; a mínima geração de entulho e, por último, boas condições térmicas, como se verificou anteriormente.

Dada a semelhança do sistema construtivo que emprega a 'novaterra' para as habitações indígenas e do projeto do Cajueiro Seco com aquele proposto para o concurso da Caixa, é possível se chegar à conclusão de que a resistência ao emprego da terra é dificultada por um complexo sistema de interesses que envolve políticos, agentes imobiliários, incorporadores, construtores e produtores de materiais convencionais. 


\section{2. A questão das tipologias destinadas às habitações de diversos povos indígenas.}

No que se refere às moradias indígenas, ao se fazer uma análise da atuação, do apoio e agenciamento de edificações oferecido pela FUNAI, pelos governos estaduais e locais em programas e projetos em que se disponibilizam a construção de habitações ou o 'melhoramento' das mesmas, percebe-se que, infelizmente, são ações totalmente desvinculadas da realidade de cada agrupamento/etnia indígena. Via de regra, tem ocorrido um distanciamento significativo das identidades construtivas de origens indígenas, principalmente quanto ao emprego de materiais e a tipologia adotada para as habitações.

Analisando-se projetos implantados em comunidades indígenas de áreas periféricas de Porto Alegre, no Rio Grande do Sul e do Paraná, especificamente nos arredores de Curitiba, pela COHAPAR, observa-se que eles não dialogam com as características dos grupos indígenas que acabam por receber moradias que, fisicamente, nada reforçam ou valorizam de sua identidade e cultura históricoconstrutiva, como se constata na fig.4.06.
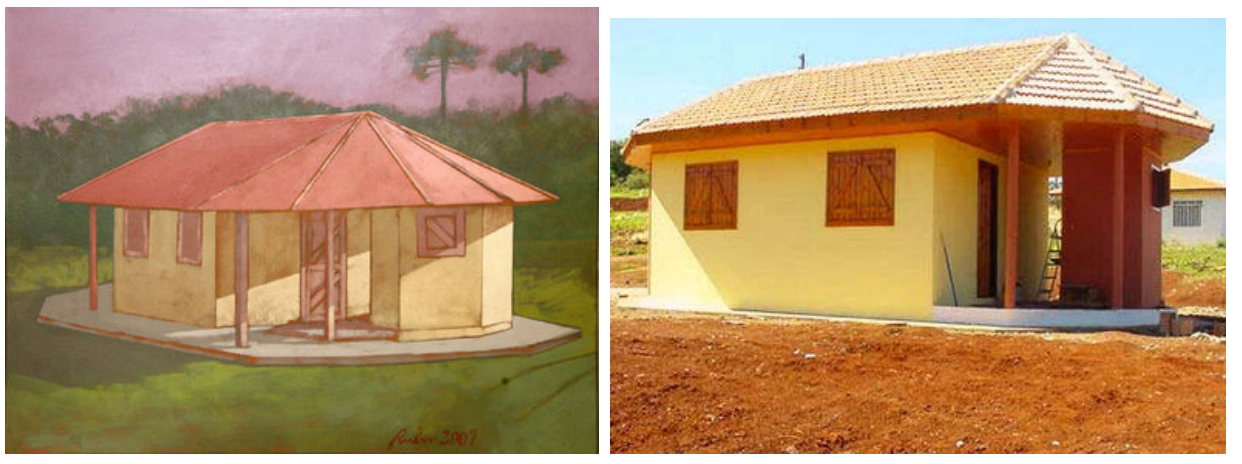

Fig. 4.06. Habitação Indígena executada pela COHAPAR para um grupo Kaikang. 
No caso específico do modelo ora apresentado, implantado pela COHAPAR no Paraná, o que está se levando em consideração na análise não é tanto a forma, mas o sistema construtivo adotado, já que o mesmo empregou essencialmente convencionais materiais industrializados, que em nada contribuem para resgatar os valores histórico -identitário -culturais dos índios Kaiakang.

Já no Rio Grande do Sul, na tentativa de suprir a necessidade de moradias para os índios da etnia Mybiá Guarani, assentados junto da Lomba do Pinheiro, o governo implantou casas de madeira. Estas, ainda que interessantes e bem construídas, aproxima-se da forma de morar dos camponeses e não dos índios, o que demonstra, claramente, que não há interesse dos grupos políticos locais em colaborar para a permanência dos índios e sim, como na lógica de um jogo político e de interesses explícitos, em poder afirmar que estão através de ações como esta minimizando os problemas e conflitos acerca da habitação indígena. O conjunto de imagens da fig.4.07 reforça a questão apresentada.

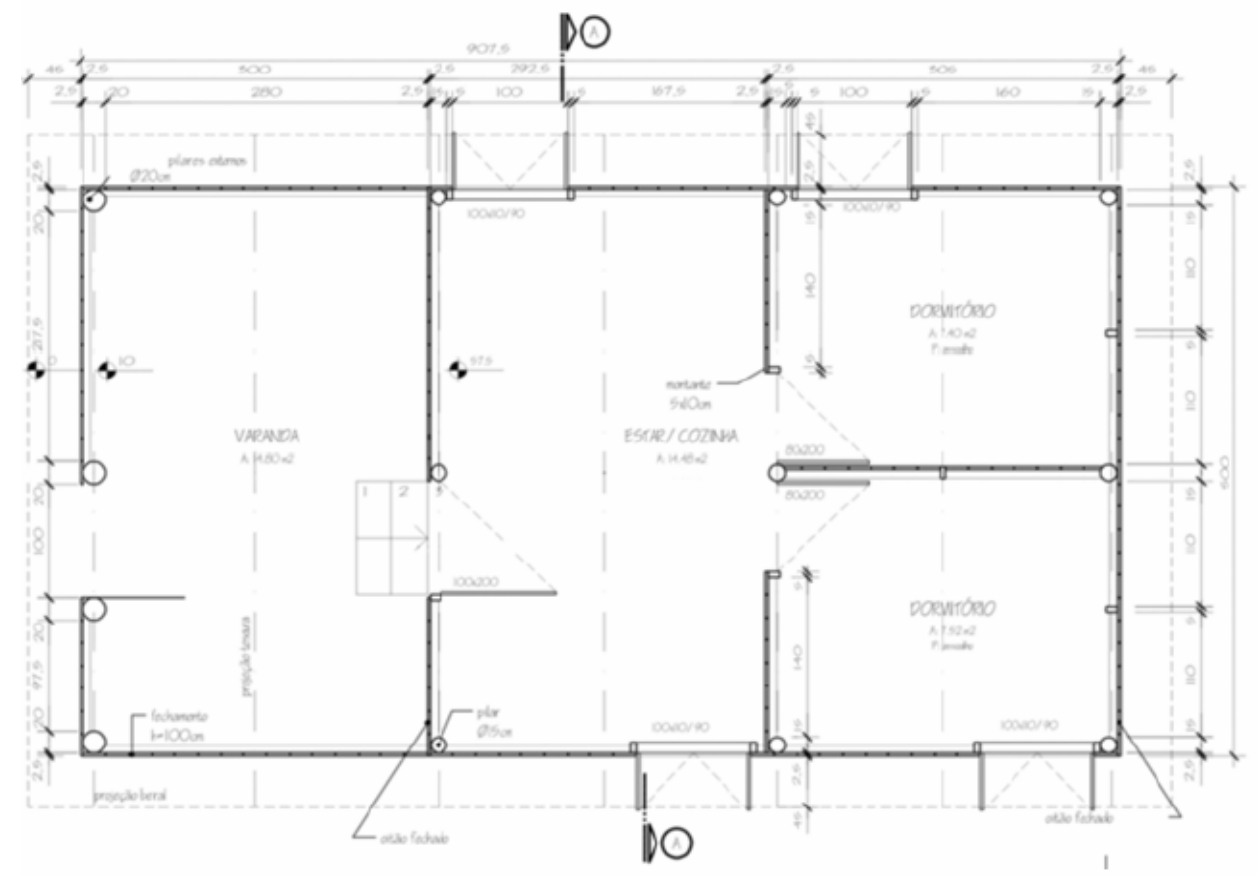

Planta Baixa da unidade habitacional proposta pelo Governo RS 

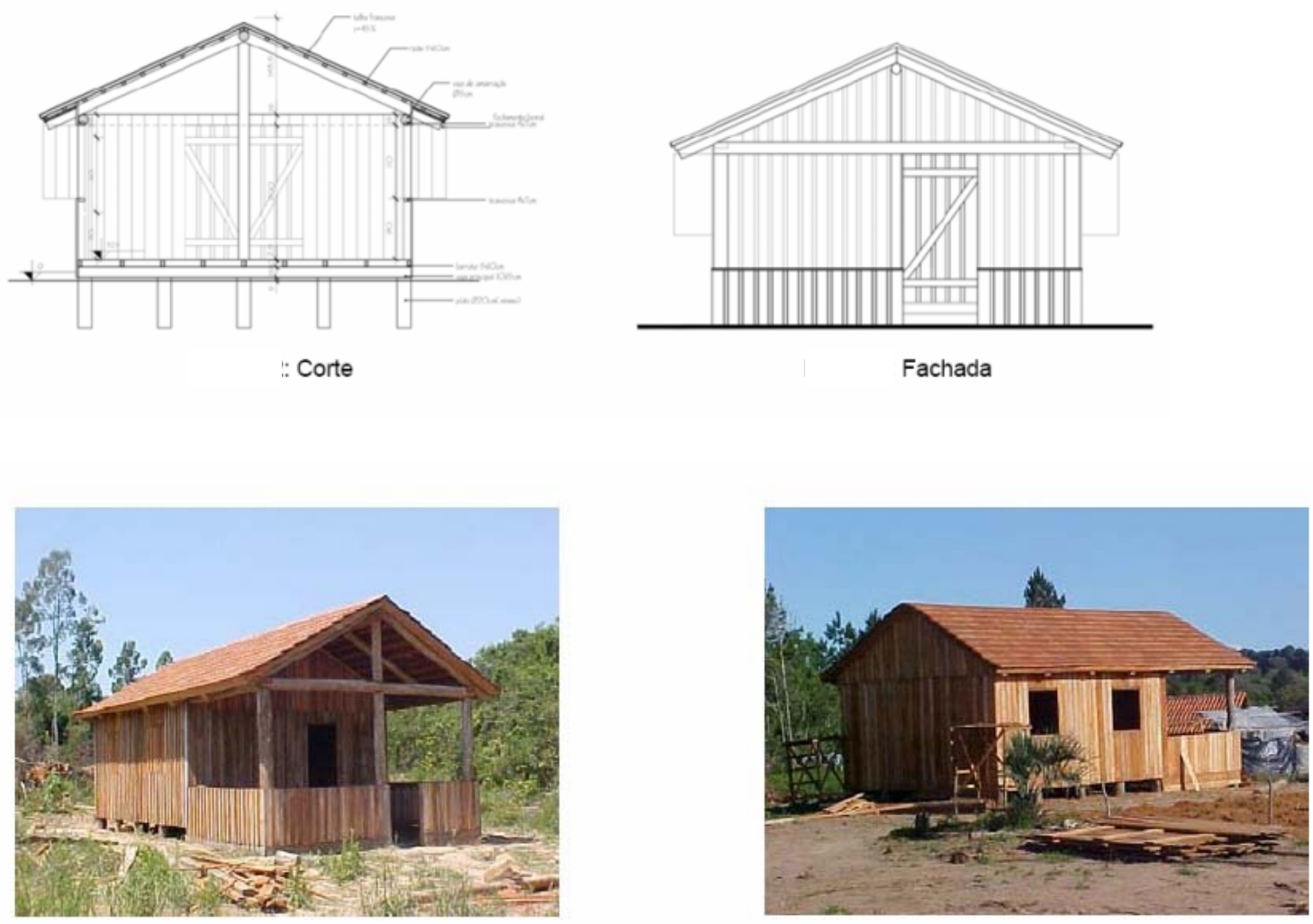

: Vista frontal e lateral da habitação.

Vista dos fundos e lateral da habitação

No caso da habitação indígena implantada no Rio Grande do Sul, o que está em jogo não é o material e, sim, a forma convencional das casas rurais gaúchas. Nesta proposta, foram totalmente desprezadas as características construtivas da etnia Mybiá-Guarani. Porém, a Universidade realizou um amplo estudo junto ao mesmo grupo indígena e propôs o modelo apresentado na fig.4.08 que, além de atentar para aspectos culturais dos Mybiá-Guarani, recupera e reinterpreta a tecnologia construtiva desse grupo. 

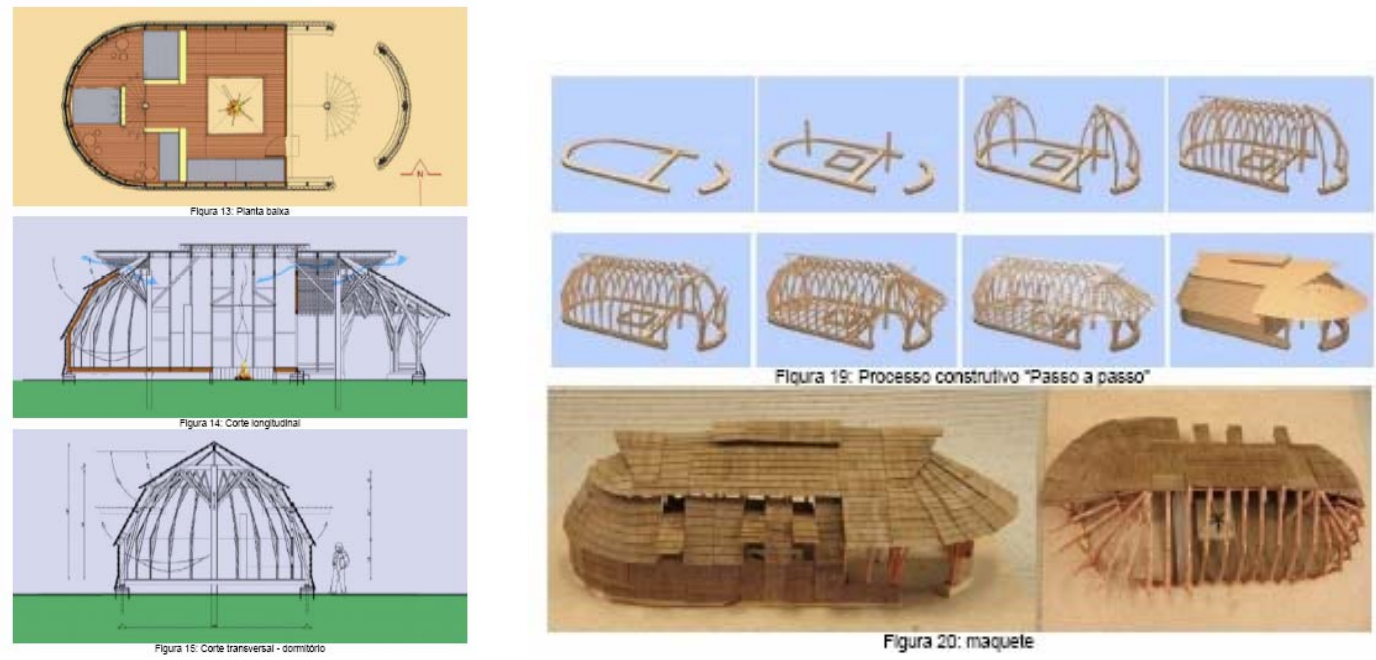

Fig.4.08. A proposta realizada pela Universidade para a Aldeia Mybiá Guarani, no estado do Rio Grande do Sul.

Seja em habitações rurais ou urbanas, o emprego da terra, em particular da 'novaterra,' pode melhorar e contribuir para a abertura de possibilidades que dizem respeito a qualquer tipo de obras, sejam novas ou ampliações, possibilitando a estas edificações uma série de atributos de qualidade que se revertem na satisfação dos moradores, no equilíbrio térmico, na reutilização de tecnologias construtivas ancestrais eficientes e simples.

Não é possível fechar os olhos diante das necessidades de habitações para os milhões de brasileiros que não possuem moradias em condições dignas; não é possível a atitude descompromissada diante da exploração dos recursos; não é possível negar os índices da geração de resíduos e emissão de CO2 originários da construção civil e da geração de resíduos da construção civil. Cabe uma postura madura, consciente, equilibrada, tanto no que diz respeito às tecnologias empregadas, quanto no que diz respeito ao resgate das identidades construtivas brasileiras como maneira de preservar o resgate da memória local que, em última análise, reconstrói os elos perdidos da recente e fragmentada história brasileira. 


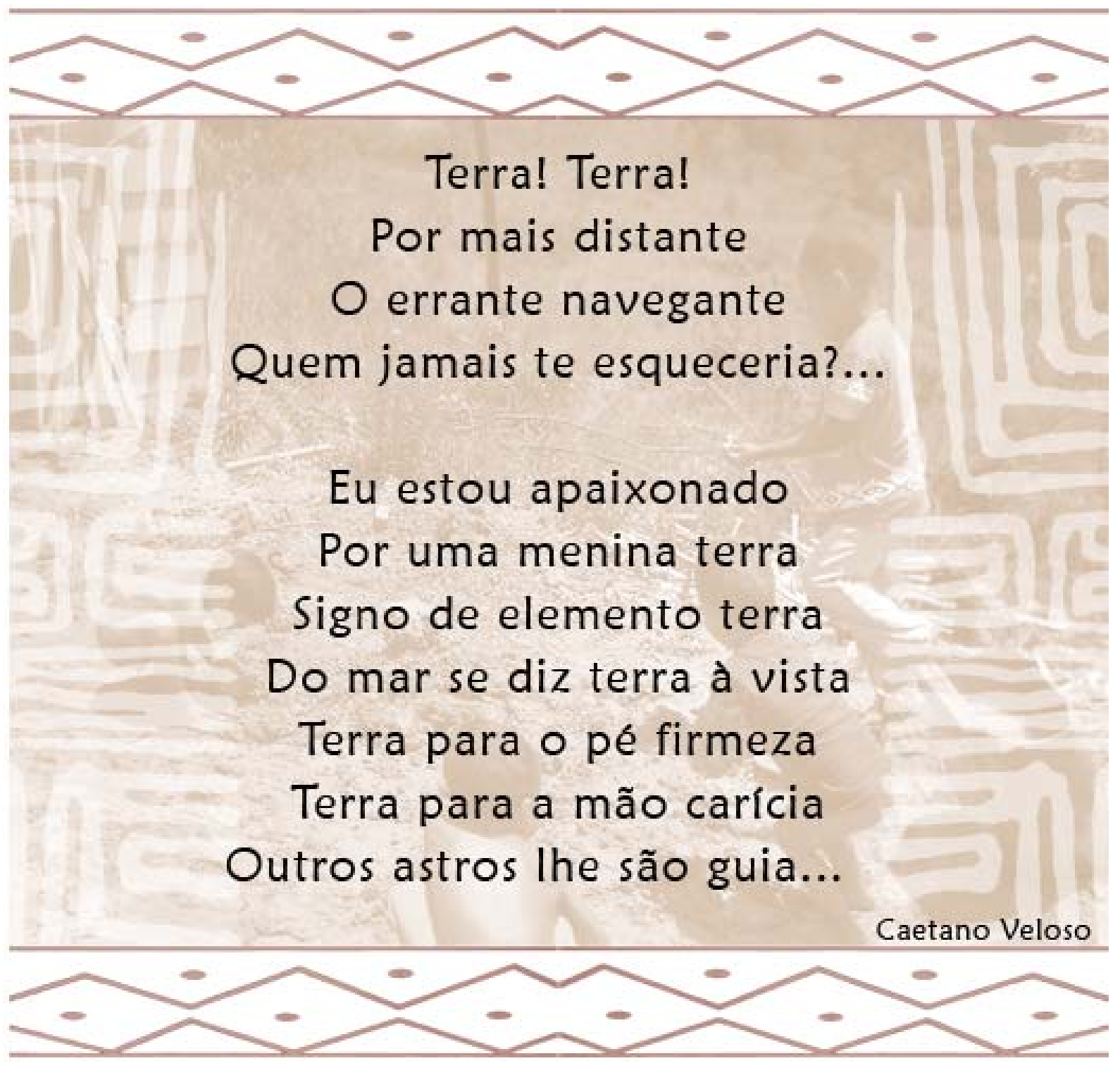

5. CONCLUSÕES E CONSIDERAÇÕES FINAIS

Em 1958, o professor Álvaro Milanez, posteriormente citado por FARIA (2002), já dizia: "hoje em dia é ponto pacífico: não há governo que disponha de recursos financeiros capazes de permitir o financiamento da construção ou simples melhoria da casa própria de todos quantos vivem em condições precárias. Diante desta impossibilidade material não há senão o recurso de se fazer com que o homem do campo construa ou melhore a sua casa com os seus próprios meios, usando os 
materiais disponíveis na localidade e empregando a mão- de- obra da própria família (ajuda própria) ou com o auxílio dos amigos e vizinhos (ajuda mútua).

Existe, porém, a necessidade de orientar e esclarecer o homem do campo, desejoso de construir ou simplesmente melhorar sua casa. Esse trabalho de orientação, de esclarecimento, de assistência técnica, enfim, poderá ser dado por todos quantos têm responsabilidade no meio rural: educadores rurais, líderes de comunidade, professores, inspetores de saneamento ou simples encarregados de obra, mantidos pelas Prefeituras do interior a fim de assistir o rurícola brasileiro".

Mesmo tendo passados 40 anos, tal afirmação se aplica totalmente ao grupo Xucuru-Kariri remanejado, e também às comunidades rurais e urbanas precárias existentes em grande número na nação-continente brasileira.

Quanto aos Xucuru-Kariri, a 'novaterra', a exemplo das recomendações de MILANEZ (1958), essencialmente emprega os materiais locais. Ao ser submetida às avaliações térmicas em três situações distintas, demonstrou ser uma opção contemporânea sustentável e satisfatória.

Assim verifica-se que o emprego da terra como material de construção, que remonta aos tempos mais remotos da fixação do homem sobre a terra, diante do quadro do comprometimento do ambiente natural, se apresenta de forma viável, ecológica e sustentável, que pode não só, em países de climas quentes como o Brasil, possibilitar o 'ganho térmico', mas também contribuir como um meio eficiente, seguro, econômico e saudável como possibilidade concreta de aquisição ou 
melhoramento de habitações. E, no que diz respeito aos índios Xucuru-Kariri, a pesquisa se encerra acreditando que, através da terra, depois de ter sido resgatado um percurso de mais de 15 anos e situações diversas vivenciadas do grupo remanejado, haja outras formas de entendimento que possibilitem, de fato, a 'sedução' dos Xucuru-Kariri pela 'novaterra' que eles mesmos denominaram. 


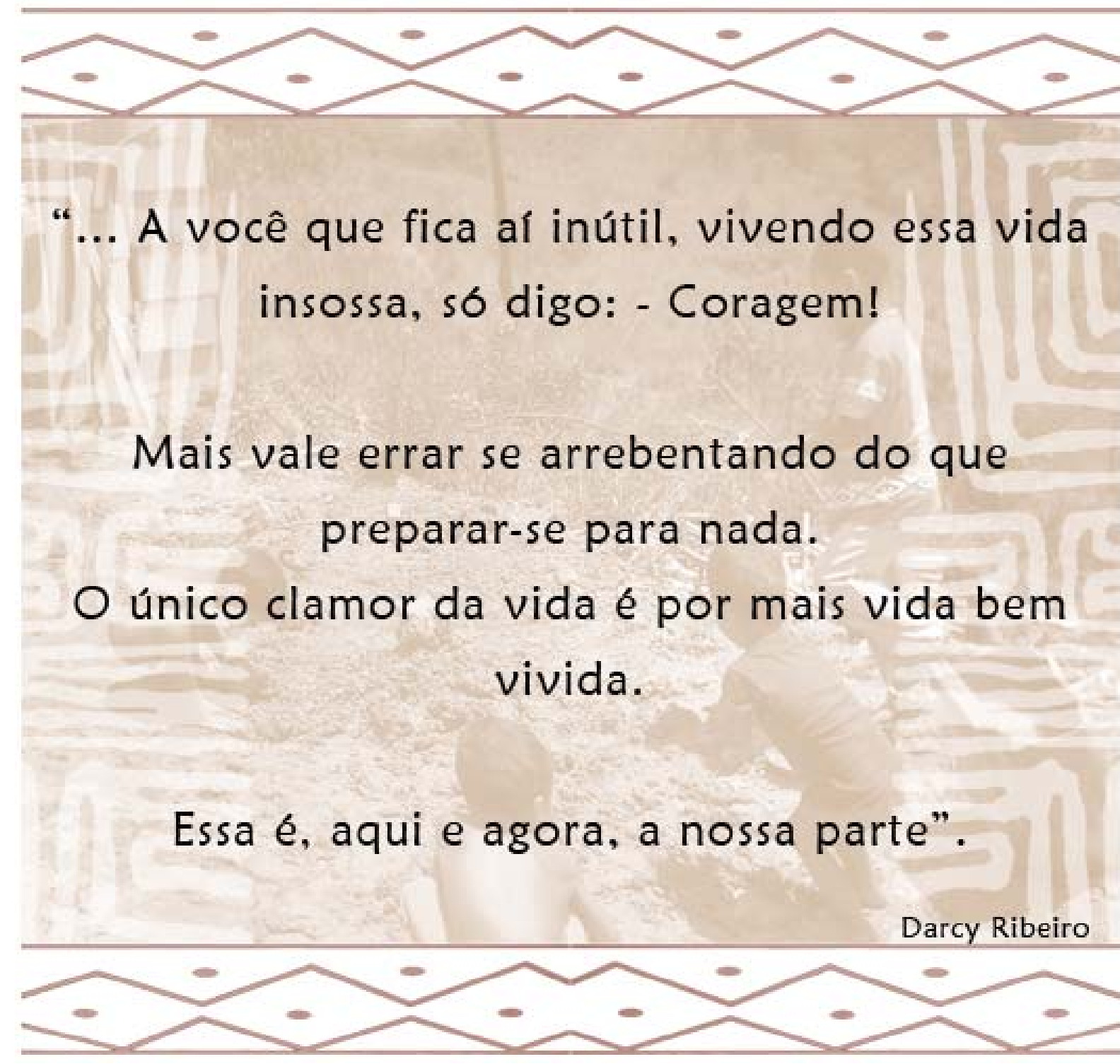

6. BIBLIOGRAFIA 


\subsection{BIBLIOGRAFIA CITADA}

AGOPYAN,V.(1991). Materiais reforçados com fibras para a construção civil nos países em desenvolvimento: o uso de fibras vegetais. 204p. Tese (Livre-Docência).Departamento de Engenharia e Construção Civil, Escola Politécnica da Universidade de São Paulo.

ALFONSIN, B. e FERNANDES,E (2004). Direito à moradia e proteção dos direitos humanos. p. 31-39. Em: Direito à moradia e segurança da posse no Estatuto da Cidade. Belo Horizonte: Forum, 262p.

ALMEIDA, F e SILVA, A.B.(2006). Conflitos Fundiários.p.787-789. Em RICARDO, B e F(Org.). Povos indígenas no Brasil 2001-2005, São Paulo: Instituto Socioambiental, 879p.

ALMEIDA, L.S. e GALINDO,G.(2002). Índios do Nordeste: temas e problemas 3. Maceió: EDUFAL, 270p.

ALVARENGA, M.A.A.(1984). Arquitetura de Terra. Técnicas Construtivas. Apostila Digitada. Belo Horizonte. 25p.

AMORIM,M.C.C.T. e MINAKI,C(2005).Características de temperatura e conforto térmico em ambiente urbano e rural: episódios de verão.Comunicação. XI Simpósio de Geografia Física Aplicada. Anais. São Paulo: USP,FFLCH,9p.

ANTUNES, C.(1973). WAKONA-KARIRI-XUKURU. Maceió: Universidade Federal de Alagoas. 155p.

ANTUNES, C.(1983). Índios de Alagoas: Documentário. Maceió: Editora da Universidade Federal de Alagoas. 136p. 
ARRUTI,J. M. .(2006) Etnogêneses indígenas.p.50-54. Em: Ricardo, B. e Fany.(Org). Povos Indígenas no Brasil 2001/2005. São Paulo: Instituto Socioambiental.879p.

BANDEIRA, M.L.(1972). Os Kariri de Mirandela.Um grupo indígena integrado. Estudos Baianos 6. Salvador: Universidade Federal da Bahia.

BARBOSA,R.V; PARISI, R.S.B. (2008). Análise de desempenho térmico de habitação em 'novaterra' na Reserva Indígena Xucuru-Kariri em Caldas - MG. São Paulo: Anais do ECOBUILDING. I Fórum Internacional de Arquitetura e Tecnologias para a Construção Sustentável. 5p.

BETTENCOURT, L. (2005). Cartas Brasileiras: Visão e Revisão dos Índios.p.39-46. Em: Índios no Brasil: GRUPIONI, L.D.B. Índios no Brasil. São Paulo: Global. 279p.

BORSÓI, A.G.(2008). Depoimento enviado por meio eletrônico especialmente para esta pesquisa. Poços de Caldas. Cópia impressa. 2p.

CAMINO, R. de, MULLER,S (1993). Sostenibilidad de la agricultura y los recursos naturales: bases para establecer indicadores. San José: Instituto Interamericano de Cooperación para la Agricultura Projeto IICA/GTZ.134p.(Serie documentos de programas/ IICA, 38.

CÂNDIDO, A. (1992/1996). Apresentação do livro de FERRAZ, M. Arquitetura Rural na Serra da Mantiqueira. São Paulo: Instituto Lina Bo e P.M. Bardi, 93p., p.8-9.

CARDOSO de OLIVEIRA. R. (1976). O processo de assimilação dos Terêna. Rio de Janeiro. Livraria Francisco Alves Editora. 149p.

CARLETTO,C (2005). Subcoberturas : aplicação de isolantes térmicos em sistemas de coberturas. São Carlos.101p. Dissertação de Mestrado. Escola de Engenharia de São Carlos. Centro de Recursos Hídricos e Ecologia Aplicada da Universidade de São Paulo. 
CARVALHO,P.(2006). Uma triste visita às aldeias. Em: RICARDO, B e F(Org.). Povos indígenas no Brasil 2001-2005, São Paulo: Instituto Socioambiental, 879p.

CASTAÑEDA, G.N.,ALBORES,J.L.G. et el.(2004).Propuesta de desarrollo comunitario en la Reserva de la Biosfera "La Sepultura" municipio de Arriaga, Chiapas, México. (Anais).Conferência Brasileira de Materiais e Tecnologias não convencionais: habitações e infra-estrutura de interesse social.Brasil NOCAMAT 2004.Pirassununga.7p. Cópia Impressa.

CASTAÑEDA, G.N. e GONZÁLES (2001). "MI CASA DE BAJAREQUE. Una Alternativa Apropiable para el Sector de Ingresos Bajos. Mérida Yucatán: Ponencia presentada en el seminario taller Iberoamericano "Sistemas de techos para la vivienda popular". julh. 2001.6p. Cópia Impressa.

CHAUÍ, M.(2005). 500 anos- Caminhos da Memória, Trilhas do Futuro, p.11-12. Em: Em: Índios no Brasil: GRUPIONI, L.D.B. Índios no Brasil. São Paulo: Global. 279p.

CORONA e LEMOS,C.A.C.(1972). Dicionário de Arquitetura Brasileira.São Paulo:Edart. 240 p.

DANTAS,B. e outros(1992). Os povos indígenas do nordeste brasileiro, um esboço histórico. Em: CARNEIRO da C., M.(Org.). História dos índios no Brasil. São Paulo: FAESP/SMC/Companhia das Letras.648p.

DERANJI,J.(2001). Do descobrimento ao Século XIX, p. 026-062. Em: Arquitetura Brasil 500 anos, Vol.1. Recife: Universidade Federal de Pernambuco, 328p.

DETHIER, J.(Coord) (2003). Arquitecturas de Terra. Lisboa. Fundação Calouste Gulbenkian. Tradução de Helena Cardoso da ed. original de 1981.

DI MARCO,A.R. (1984). Pelos caminhos da Terra. Revista Projeto, n65. P.47-52, jul. 
ELIAS, J.L. apud CORTESÃO, J. p. 167.(2000). Moradia Indígena: Resistência dos Índios americanos. Em: Índios do Nordeste: Temas e Problemas 2. Almeida L.S, Galindo, M. e Elias, J.L. Maceió: EDUFAL, 231p.

ESCAMIROSA MONTALVO, L.F.(2005). Prólogo em LOPES GONZÁLES, A. Manual de Autoconstrucción. Aula Rural de Bajareque.Tuxtla-Gutiérrez: COCOES.54p.

FARIA,O.B.(2002). Utilização de macrófitas aquáticas na produção de adobe: um estudo de caso no reservatório de Salto Grande. São Carlos. Tese (Doutorado).200p.- Escola de Engenharia de São Carlos. Centro de Recursos Hídricos e Ecologia Aplicada. Universidade de São Paulo.

FERRAZ, M.C. (1992/1996). Arquitetura Rural na Serra da Mantiqueira. São Paulo: Instituto Lina Bo e P.M. Bardi, 93p.

FIALHO, V. (2005). Configurando a mobilização indígena no Nordeste brasileiro. Disponível em: < http://www.comciencia.br/reportagens/2005/04/11.shtml >. Acesso em: 22 abr. 2008.

GIVONI, B.(1998). Climate Considerations in Buliding and Urban Design.Van Nostrand Reinhold Co. Distributed by John Wiley and Sons. 490p.

GHISI,E., LAMBERTS,R. et al.(2003). Normalização em conforto ambiental: desempenho térmico, lumínico e acústico em edificações. São Paulo: Coletânea Habitare.Vol.3.26p. Disponível em <http://www.habitare.org.br/pdf/publicacoes/arquivos/113.pdf> Acesso em: 29.maio. 2007.

GRUPIONI, D.F. (2006). Povos recuperam antigos locais de moradia.p.392-396. Em: RICARDO, B e F(Org.). Povos indígenas no Brasil 2001-2005, São Paulo: Instituto Socioambiental, 879p.

GRUPIONI, L.D.B. (Org.) (2005). Índios no Brasil. São Paulo: Global.279p. 
HOHENTHAL,W. (1954).Notes on the Shukuru Indians of Serra Araroba, Pernambuco, Brazil in Revista do Museu Paulista, N.S., Vol. VIII, São Paulo: p. 92116.

INSTITUTO SOCIOAMBIENTAL. Disponível em: < http://www.socioambiental.org/inst/index.shtm $\quad$ e http://www.socioambiental.org/pib/portuques/quonqua/qoqindex.shtm>. Acesso em: 25 mai. 2008.

LADEIRA,M.I.(2006). Depois da migração, o reencontro. p.519-520. Em: RICARDO, B e F(Org.). Povos indígenas no Brasil 2001-2005, São Paulo: Instituto Socioambiental, 879p.

LADEIRA,M.I.(2006) São Paulo na terra dos índios p.831-832.Em: RICARDO, B e F(Org.). Povos indígenas no Brasil 2001-2005, São Paulo: Instituto Socioambiental, 879p.

LEGAL RESOURCES FOR HOUSING RIGHTS- International and National Standards (2000) $2^{\mathrm{a}}$ edição. Vol.4, 89 p. Disponível em: < http://www.cohre.org/store/attachments/COHRE\%20Sources\%204.pdf $>$. Acesso em: 03 mai.2007.

LEMOS,C.A.C.(1999). Casa paulista: história das moradias anteriores ao ecletismo trazido pelo café. São Paulo: EDUSP, 264p.

LÉRY, J. de (1961). Viagem à Terra do Brasil. Coleção General Benício. Rio de Janeiro: Biblioteca do Exército Editora, 318p.

LIVINGSTON,R.(2004). Arquitectos de La comunidad. El Método. Buenos Aires:Kliczkowski, 320p.

LOPES,W.G.R.(1998). Taipa de mão no Brasil. Levantamento e Análise de construções. São Carlos.233 p.Dissertação de Mestrado. Departamento de Arquitetura da escola de Engenharia de São Carlos. 
LORENZO GÁLLIGO,P.(Org.)(2005). Un techo para vivir. Tecnologias para viviendas de produccion social en America Latina. Barcelona: CYTED/UPC. 559p.

LUCAS,I.B., ALBARRACIN,O. e CARESTIA,C. Comportamiento Energetico de tipologias barreales em San-Juan.Argentina. Anais do Siacot.5p.

MARTINS, S.A.C. (1994).Os caminhos da aldeia...índios Xucuru-Kariri em diferentes contextos situacionais. Recife.130p. Dissertação de Mestrado.Universidade Federal de Pernambuco.

MILANEZ, A.(1958). Casa de Terra. As técnicas de estabilização do solo a serviço do homem do campo. Rio de Janeiro: Ministério da Saúde. Serviço Especial de Saúde Pública.122p.

MINKE,G.(2001). Manual de construccion em tierra. La tierra como material de construcción y su aplicación em la arquitectura actual. Montevidéu. Editoral Fin de Siglo. 222p.

MONTEIRO, C.A.(1963). Sobre a análise geográfica de seqüências de cartas de tempo.(Pequeno ensaio metodológico sobre o estudo do clima no campo da Geografia. Revista Geográfica, XXXII (58): 169-179, Rio de Janeiro, IPGH.10p.

MONTEZUMA, R. (Org.) (2002). Arquitetura Brasil 500 anos, Vol.1. Recife: Universidade Federal de Pernambuco, 328p.

MOYA,V.(1988).La Vivienda indígena del México y del Mundo. Ciudad do México: UNAM, 1 Coordinación de Humanidades. $3^{\mathrm{a}} \mathrm{Ed}$.

MURA, F.(2006). À procura do bom viver. Território, tradição de conhecimento e ecologia doméstica entre os Kaiowa. Rio de Janeiro. 477p. Tese (Doutorado). Museu Nacional. Departamento de Antropologia Social da Universidade Federal do Rio de Janeiro.

OLGYAY,V.(1963).Design with climate. New Jersey: Princeton University Press. 
OLGYAY,V.(2004). Arquitectura y clima. Manual de Diseño Bioclimático ara Arquitectos y Urbanistas. Barcelona: G.G.203p.

OLIVEIRA, J.P. (1994). A viagem da volta: reelaboração cultural e horizonte político dos povos indígenas do Nordeste. Em: Atlas das Terras Indígenas/Nordeste. Rio de Janeiro: PETI/Museu Nacional/UFRJ.p.V-VIII.

OLIVEIRA, J.P.(1999). Uma etnologia dos "índios misturados"? Situação colonial, territorialização e fluxos culturais. Rio de Janeiro: Mana vol.4 n.1 Abr. 1998. ISSN 0104-9313. Disponível em: $<$ http://www.scielo.br/scielo.php?script=sci_arttext\&pid=S0104 93131998000100003\&lng=en\&nrm=iso>. Acesso em: 02 Jul 2008. doi: 10.1590/S0104-93131998000100003.

OLIVEIRA, J.P. (Organizador) (2004). A viagem da volta. Etnicidade, política e reelaboração cultural no Nordeste indígena, $2^{\mathrm{a}}$. ed. Rio de Janeiro.261p. p.19.

PARISI,R.S.B.; VILLAÇA, A.C.; FARIA, O.B. et al.(2007). A terra como fonte de geração de renda, de esperança e de vida: relato de uma experiência em São José do Rio Pardo-SP (Brasil). Aveiro, PT: Terra em Seminário 2007. V Seminário de Arquitectura de Terra em Portugal. p. 40-44. ISBN. 978-972-8479-49-7. $1^{\text {a }}$ Edição, Out.2007.

PEREIRA Fo.,G et. al.(2002). Projeto Xucuru-Kariri .Fase I. Diagnóstico SócioCultural. Poços de Caldas: PUC-Minas, 2003.(cópia impressa).

RIBEIRO, B. G. (1980). A civilização da palha. A arte do trançado dos índios do Brasil. São Paulo. 590 p. Tese (Doutorado).Faculdade de Filosofia, Letras e Ciências Humanas da Universidade de São Paulo.

RIBEIRO, B. G.(Coord.)(1986).Suma Etnológica Brasileira (3 vols).Vol.2. Tecnologia Indígena. Petrópolis: Vozes. 
SÁ, C.(1982). Aldeia de São Marcos: transformações na habitação de uma comunidade Xavante. São Paulo: USP. 220 p. (Dissertação de Mestrado)

SANTOS, L. G. (2005). Amigos dos índios: os trabalhos da Comissão de Índios no Brasil.p.29-36. Em: Î́ndios no Brasil: GRUPIONI, L.D.B. Índios no Brasil. São Paulo: Global. 279p.

SAVASTANO JR, H. PIMENTEL, L.I (2000). Viabilidade do aproveitamento de resíduos de fibra vegetal para fins de obtenção de material de construção. Campina Grande: Revista Brasileira de Engenharia Agrícola e Ambiental, PB, v. 4, n. 1, p. 103-110.

SERAPIÃO, F(2008). Casa-Grande e Sobrados.Em Projeto e Design Virtual. Disponível em: < www.arcoweb.com.br/debate/debate82.asp>. Acesso em 05.jul.2008.

SIQUEIRA,T.C.P.A., AKUTSU.M. et al (2005).Dados climáticos para a avaliação de desempenho térmico de edificações. Em: Ouro Preto: Revista da Escola de Minas 58(2), p. 133-138. abr.jun.2005.

SILVA,A.C. (2005). Avaliação do comportamento térmico de habitações P10X10 em San Antonio de los Baños (Cuba). Tese (Doutorado em Ciências da Engenharia Ambiental) - Escola de Engenharia de São Carlos. São Carlos: CRHEA/EESC, 197p.

SMITH, R.C.(1955). Arquitetura Colonial. Salvador: Progresso Editora. 74 p.

SORRE,M.(1951). Les fondements de La Géographie Humaine.Les fondements biologiques.Essai d'une ecologie de i'homme. Tomo I. Paris: Armand Colin, 448p.

TORRES, L.B. A terra de TIIXI e TXILIÁ.(1973). Palmeira dos Índios nos séc. XVIII e XIX.Maceió: Sergasa Edit.,130p.

VECCHIA,F.A.S. e SILVA, A.(2002). Utilização de resíduos sólidos, tetrapak, na construção de edificações sustentáveis: análise do comportamento térmico de 
subcoberturas na situação transicional primavera - verão. São Paulo : FAU-USP. Anais do Seminário Internacional, Sustentabilidade Arquitetura Desenho Urbano. p. 1518-1526.

VIÑUALES,G.(2002).Vocabulario de Arquitecturas de Tierra em América. Em:NEVES,C.(Org.). Anais. I Seminário Ibero-Americano de Construção com Terra. Salvador: UFBA.16-12 set.2002. 224p.

WORTMANN,E.(1983/1984). O Sítio Camponês em Anuário Antropológico n.81. Rio de Janeiro: Tempo Brasileiro, 1983-1984.259p.

\subsection{BIBLIOGRAFIA CONSULTADA}

AKASAKI, J.L.(1999). O tijolo cru como elemento construtivo de baixo impacto ambiental. São Paulo: FAU-USP. Cópia Impressa (Tese de Doutoramento).

ALMEIDA,L.S., VILELA,R. et al. Xucuru-Kariri (2005): Saúde na Fazenda Canto. Maceió:EDUFAL, 148p.

Gestão do processo de projeto na construção de edifícios (2001). ANAIS do Workshop. São Carlos-SP: 22-23 de Nov. Volume impresso.

ARAÚJO, I. S. S.(1998) Televisão e indianidade: questões sobre a construção narrativa da imagem do índio pela televisão. Informare: Cadernos do Prog. Pós-Graduação em Ci da Inf, Rio de Janeiro : s.ed., v. 4, n. 2, p. 30-46, jul./dez.

ARINI, R. .(1999). Arquitetura de Terra.Solo/Cimento/Cal. São Paulo: FAU-USP, Cópia Impressa (Tese Doutoramento).

ARRUTI, J.M. (2006). Etnogêneses indígenas in Povos Indígenas do Brasil 2001/2005, São Paulo: Instituto Socioambiental, pp.50-54.

ARRUTI, J. M. A.(1998). A emergência dos "remanescentes" : notas para o diálogo entre indígenas e quilombolas. Maná, Rio de Janeiro : Museu Nacional, v. 4, n. 1, p. 7-38, abr. 
(1997). Morte e vida no nordeste indígena : a emergência étnica como fenômeno histórico regional.(1995). Estudos Históricos, Rio de Janeiro : APDOC, v. 8, n. 15, p. 57-94.

BARBOSA, N. e MATTONE, R.(2002). Construção com terra crua in Anais do I SIACOT. $1^{0}$ Seminário Ibero-Americano de Construção com Terra, Salvador-BA 16-18 de set.(CDROM), CEPED/PROTERRA.

BOFF, Leonardo. (2001). O casamento entre o céu e a terra. Contos dos povos indígenas do Brasil.São Paulo, Salamandra,160p.

BRASILEIRO, S.B.(2002). Construções em terra no Brasil: o antigo e o moderno in Anais do I SIACOT. $1^{\circ}$ Seminário Ibero-Americano de Construção com Terra, Salvador-BA 16-18 de set. (CD-ROM), CEPED/PROTERRA.

BSHF.(2003). Programa Arquitecto de la Comunidad. CUBA. CD-Rom Leicestershire: Building and Social Housing Foudation.

CARNEIRO DA CUNHA, M. (organizadora) (1992) - História dos índios no Brasil. São Paulo: Editora Companhia das Letras/ Secretaria Municipal de Cultura, 611 p.

COSTA, M. H. F.(1997). Representações iconográficas do corpo em duas sociedades indígenas: Mehinaku e Karajá .Rev. do Museu de Arqueol. e Etnol., São Paulo : MAE, n. 7, p. 65-91.

CUADRAT, J.M.\& PITA, M.F.(1997). Climatologia. Madrid: Ediciones Cátedra. $2^{\mathrm{a}}$ Edição.

CYTED/HABYTED PROTERRA. Proyecto XIV.6, Julio del 2003, Primera Parte. Capítulo 2. 9. Bahareque y Pau-a-pique, pp.257-283.

CLIMANÁLISE - Boletim de Monitoramento e Análise Climática. (2005). São José dos Campos, V.20, n.10, disponível em: $<$ http://www.cptec.inpe.br/products/climanalise/1005/index.html> acesso em: 14/jan./2008.

CURTIS,J.N.B. Arquitetura Tradicional no Brasil.(2003) Registros de uma expeiÇencia técnica e didática. Porto Alegre,496p.

EASTON, D.(1996). The rammed earth house. Totnes: Chelsea Green, 272p. 
FARIA, O. B.(2002). Utilização de macrófitas aquáticas na produção de adobe: um estudo de caso no reservatório de Salto Grande (Americana-SP). 2002. 200p. Tese (Doutorado em Ciências da Engenharia Ambiental) - Escola de Engenharia de São Carlos, Universidade de São Paulo. São Carlos. Disponível em: http://www.teses.usp.br/teses/disponiveis/18/18139/tde-10022003-103821/_acesso em: 13.abr.2008.

FATHY, H.(1976). Architecture for the poor: an experiment in rural Egypt. Chicago: University of Chicago Press, 233p.

(1980). Construindo com o povo. Arquitetura para os pobres, São Paulo: Salamandra/EDUSP.

FIALHO, V. "Configurando a mobilização indígena no Nordeste brasileiro. Disponível em: < http://www.comciencia.br/reportagens/2005/04/11/shtml > acesso em: 29/04/2008.

GALLOIS, D.T.(1991). O acervo etnográfico como centro de comunicação intercultural. Ciências em Museus, Belém : MPEG, v. 1, n. 2, p. 137-42.

(1998). Brasil : el caso de los Waiãpi. IWGIA: Documento, Copenhague : IWGIA, n. 23, p. 175-93.

(2001). Essa incansável tradução : entrevista. Sexta Feira: Antropologia, Artes e Humanidades, São Paulo : Pletora, n. 6, p. 103-21, 2001.

(1997/998). Os povos indígenas e a questão da autonomia. Cadernos de Campo, São Paulo : USP, v. 8, n. 7, p. 172-80.

GIVONI, B. (1998). Climate Considerations in Building and Urban Design. New York:Van Nostrand Reinhold Co.

GIVONI, B. \& VECCHIA, F.A.S. (2001). Predicting thermal performance of occupied houses. Florianópolis-SC: Proceedings do $18^{\text {th }}$ International Conference on Passive and Low Energy Architecture- PLEA. 
GRUPIONI, L. D. B. (organizador) - Índios no Brasil. Brasília: Ministério da Educação e do Desporto, 1994, 279 páginas.

GRUPIONI, L. D. B.(1994). Da aldeia ao parlamento : a educação escolar indígena na nova LDB. Em Aberto, Brasília : Inep, v. 14, n. 63, p. 88-92, jul./set.

(2000).Educação e povos indígenas : construindo uma política nacional de educação escolar indígena. Rev. Bras. de Estudos Pedag., Brasília : Inep, v. 81, n. 198 , p. $273-83$, mai./ago.

INO, A. e Lopes, W.G.R.(2003). Aspectos construtivos da taipa de mão in Técnicas Mixtas de Construcción com Tierra. CYTED/HABYTED PROTERRA. Proyecto XIV.6, Jul. Primera Parte. Capítulo 1. p.16-36.

HAYS, A. e Matuk, S.(2003). Recomendaciones para la elaboración de normas técnicas de edificacion com técnicas mixtas de construcción con tierra. CYTED/HABYTED PROTERRA. Proyecto XIV.6, Julio del 2003, Primera Parte. Capítulo 2. 9. Bahareque y Pau-a-pique, p.257-283.

HERNANDEZ DIAZ, J.(1993). La constituición de la identidad étnica entre los Fulnios del nordeste brasileño. Montalban, Caracas : Univ. Catolica Andres Bello, n. 25, p. 99-127.

HOLANDA, S.B.(1983). Raízes do Brasil. Rio de Janeiro: Livraria José Olympio Editora, , $16^{\text {a }}$ edição.

KRUK,W. (Coord).(2002). Transferência Tecnológica para el hábitat popular. Red CYTED XIV.C, Quito, Trama/ Red CYTED XIV.C.

LAMARTINE, T.M. (Red-Resp.)(1982): Taipa. Projeto elaborado por Borsoi Arquitetos Associados in Projetos \& Fachadas, Edição Especial Casa \& Jardim nº 327/A, p. 34-41.

LEMOS, C. A. C.(1999). Casa Paulista. História das moradias anteriores ao ecletismo traduzido pelo café. São Paulo: EDUSP. (1996). História da casa brasileira. Coleção Repensando a história. São Paulo. Contexto, $2^{\mathrm{a}}$ edição. .(1989). Alvenaria Burguesa. Breve história da arquitetura residencial de tijolos em São Paulo a partir do ciclo econômico liderado pelo café. São Paulo: Nobel, $2^{a}$ edição. 
.(1999). A República ensina a morar (melhor). São Paulo:

HUCITEC/USP.

LENGEN, J. V.(2002). Manual do arquiteto descalço. Rio de Janeiro: Casa do Sonho, 697p.

LOUREIRO, M.P e LIMA, C.M.(1998). Dicionário Ilustrado de Arquitetura, Volumes I e II. São Paulo: Vicente Wissenbach Editor.

MELATTI, J. C.(1983) . Índios do Brasil. São Paulo: Editora Hucitec, 48ª . edição, 1983, 220 páginas.

MINKE, G.(2001) Manual de construcción para viviendas antisísmicas de tierra. Kassel: FEB, 2001. 51p. Disponível em: <http://www.gtz.de/basin/publications> (também versão em inglês).

MONTEIRO, C.A.F. (1969). Análise rítmica em climatologia: problemas de atualidade climática e achegas para um programa de trabalho. São Paulo: Instituto de GeografiaIGEOG-USP, Série Teses e Monografias $n^{\circ} 1$.

MONTEZUMA, R.( Org.) ( 2002). Arquitetura Brasil 500 anos. Recife: UFPE.

OLIVIEIRA JR., A. N.(1997). Faccionalismo Xukuru-Kariri e a atuação da FUNAI, in Anais do Workshop Política indigenista para o Leste e Nordeste Brasileiros. Carpina-PE: 16-21/03.

OLIVEIRA, J.P. (1993). Atlas das Terras Indígenas do Nordeste. Recife: Fundação Joaquim Nabuco.

OLIVEIRA, M.M.(2002) A conservação do patrimônio edificado em terra in Anais do I SIACOT. $1^{\circ}$ Seminário Ibero-Americano de Construção com Terra, Salvador-BA 16-18 de setembro (CD-ROM), CEPED/PROTERRA.

PARISI,R.S.B , CASTAÑEDA,G.N. \& VECCHIA, F.A.S. (2006). "O bajareque de Chiapas, México e a "Novaterra" de Minas Gerais, Brasil: um experimento integrado para a avaliação comparativa do comportamento térmico de duas moradias em terra crua". In Terra em Seminário 2007: V Seminário de Arquitectura de Terra em Portugal. Lisboa: Argumentum, 2007. 
PNUD/MINISTÉRIO DO INTERIOR. (1989). Dez alternativas tecnológicas para habitação. Brasília: PNUD/MINISTÉRIO DO INTERIOR, 1989.

PREZIA, B. e HOORNAERT, E. (2000) - Brasil indígena: 500 anos de resistência. São Paulo: Editora FTD, 263 p.

REIS Fo, N.G.(2000) Quadro da Arquitetura no Brasil . São Paulo: Perspectiva, $10^{a}$ edição. Evolução Urbana no Brasil.(2000) 1500/1720. São Paulo: Pini Editores, $2^{a}$ edição.

RIBEIRO,B. (Coord.) (1986). Suma Etnológica Brasileira. Volume n². Tecnologia Indígena. Petrópolis: Vozes/FINEP.

RIBEIRO, D.(1982). Os índios e a civilização: a integração das populações indígenas no Brasil moderno. Petrópolis (RJ): Editora Vozes, 4ª edição, 509 páginas.

RICARDO, C. A. (Ed. Resp.).(2001) - Povos indígenas no Brasil - 1996/ 2000. São Paulo: Instituto Socioambiental, $831 \mathrm{p}$.

RICARDO, B e F. (Ed. Resp.) (2006). Povos indígenas no Brasil - 2001/ 2005. São Paulo: Instituto Socioambiental, $879 \mathrm{p}$.

SALMAR, E.(2002). Mutirão: uma dimensão social contemporânea da arquitetura de terra in Anais do I SIACOT. $1^{\circ}$ Seminário Ibero-Americano de Construção com Terra, Salvador-BA 16-18 de setembro (CD-ROM), CEPED/PROTERRA.

SALVADOR, M.L.B. (1972). Os Kariris de Mirandela: um grupo indígena integrado. Salvador: Coleção Estudos Urbanos.UFBA nº 6.

SAVASTANO JR, H.(1992) Zona de transição entre fibras e pasta de cimento Portland: caracterização e inter-relação com as propriedades mecânicas do compósito. (Tese de doutorado). São Paulo- SP: Escola Politécnica da USP.

SCHADEN,E. (1969). Aculturação Indígena: ensaio sobre os fatores e tendências de mudança cultural São Paulo: Pioneira/EDUSP.

SEMINÁRIO IBERO-AMERICANO DE CONSTRUÇÃO COM TERRA. I.(2002). Salvador-BA: 16 a 18 de set. Volume Impresso. Anais. 
SOSA, M.E.(2003). Construcción con tierra cruda. Sistemas de entremado. Técnicas Mixtas tradicionales del noroeste argentino in Técnicas Mixtas de Construcción com Tierra. CYTED/HABYTED PROTERRA. Proyecto XIV.6, Julio del 2003, Primera Parte.Capítulo 5. pp.73-87.

VECCHIA, F.(2005). "Climatologia aplicada ao Ambiente Construído: análise climática, avaliação e previsão do comportamento térmico de edificações ocupadas". São Carlos, Escola de Engenharia de São Carlos, Universidade de São Paulo (EESC USP). Textos sistematizados apresentados para o Concurso de Livre-Docência.

VECCHIA, F. (1997). Clima e Ambiente construído. A abordagem dinâmica aplicada ao conforto humano. São Paulo, Faculdade de Filosofia, Letras e Ciências Humanas, Universidade de São Paulo (FFLCH USP). Tese de doutoramento.

VERÍSSIMO,F.S. e BITTAR, W.S.M.(1999). 500 anos da casa no Brasil. As transformações da arquitetura e da utilização do espaço de moradia. Rio de Janeiro: EDIOURO, $2^{\mathrm{a}}$ edição.

VILLALBA, A.C.(1999) Historia de la construcción arquitectónica. Barcelona: Ediciones UPC, $2^{\mathrm{a}}$ Edición.

ZAVATTINI, J. A. (2004). Estudos de Clima no Brasil. Campinas-SP: 2004, Alínea Editora.

WEIMER,G.(2005). Arquitetura popular brasileira.. São Paulo: Martins Fontes, 333p. 